UNIVERSIDADE DE SÃO PAULO

FACULDADE DE FILOSOFIA, LETRAS E CIÊNCIAS HUMANAS

GABRIELLA D'AURIA DE MORAIS GALO

ARTIGOS E POSSESSIVOS NA HISTÓRIA DO PORTUGUÊS PAULISTA

VERSÃO CORRIGIDA

São Paulo 
GABRIELLA D'AURIA DE MORAIS GALO

\section{Artigos e possessivos na história do português paulista}

Dissertação apresentada ao Programa de PósGraduação em Filologia e Língua Portuguesa da Faculdade de Filosofia, Letras e Ciências Humanas da Universidade de São Paulo como requisito para a obtenção do título de Mestre em Filologia e Língua Portuguesa.

Área de Concentração: Língua Portuguesa

Versão corrigida

De acordo

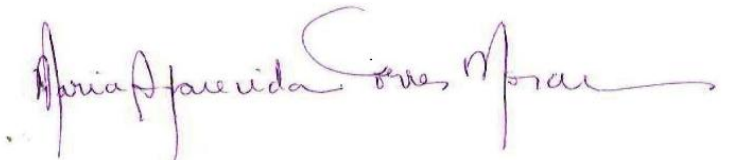

Orientadora: Profa. Dra. Maria Aparecida Torres Morais 
GALO, G. D. M. Artigos e possessivos na história do português paulista. Dissertação apresentada à Faculdade de Filosofia, Letras e Ciências Humanas da Universidade de São Paulo para obtenção do título de Mestre em Filologia e Língua Portuguesa.

Aprovado em:

Banca Examinadora

Prof. Dr. Instituição:

Julgamento: Assinatura:

Prof. Dr. Instituição:

Julgamento: Assinatura:

Prof. Dr. Instituição:

Julgamento: Assinatura: 
Dedico este trabalho aos meus pais, ao meu marido e à minha orientadora, que infinitamente me apoiaram nessa difícil caminhada. 


\section{AGRADECIMENTOS}

\section{A Deus.}

Aos meus pais, Amaury e Sandra, que tenho como exemplos e são tudo para mim.

Ao meu marido, Junior, um presente na minha vida, por me acompanhar em todo o percurso e entender os momentos de ansiedade e ausência dedicados à pesquisa.

À minha orientadora, professora Maria Aparecida Torres Morais, por ter me acompanhado em meu percurso intelectual desde a Iniciação Científica e por ter exigido que eu dispendesse os maiores esforços para realizar um bom trabalho, com seriedade e dedicação.

À professora Deize Crespim Pereira por ter disponibilizado momentos preciosos de seu tempo para me orientar no uso do programa computacional. Agradeço ainda pela sua atuação na banca de qualificação, quando então ofereceu várias sugestões que contribuíram para o desenvolvimento do meu trabalho.

Aos professores Flaviane Fernandes-Svartman, Marcia Santos D. de Oliveira, Gabriel Antunes e Maria Clara Paixão de Sousa por terem oferecido as disciplinas do Programa de Pós-Graduação. Com elas pude aperfeiçoar a prática da pesquisa científica.

Aos meus familiares e amigos, com quem compartilhei momentos tensos e felizes que esses anos me fizeram experienciar.

À Universidade de São Paulo, onde passei alguns dos melhores momentos da minha vida, pela oportunidade de realização do curso de graduação e mestrado. 


\section{RESUMO}

GALO, G. D. M. Artigos e possessivos na história do português paulista. 2016. $164 \mathrm{f}$. Dissertação de Mestrado. Faculdade de Filosofia, Letras e Ciências Humanas, Universidade de São Paulo, São Paulo, 2016.

Esta dissertação teve como objetivo articular um estudo do determinante diante das formas possessivas com base em um corpus histórico jornalístico composto de anúncios e cartas de leitores e redatores extraídos de jornais paulistas do século XIX. Focalizamos as formas possessivas seu/seus/sua/suas pré-nominais, observando a presença versus ausência do artigo definido e seus diferentes contextos. Nossas hipóteses buscaram resolver algumas questões teóricas relacionadas à estrutura do $\mathrm{DP}$ possessivo no $\mathrm{PB}$, entre elas a da opcionalidade aparente do determinante e a da variação na realização de Número no interior da estrutura. Desenvolvemos respostas e análises às questões a partir da associação de dois quadros teóricos: a teoria dos Princípios \& Parâmetros (CHOMSKY 1981, 1986) incluindo alguns refinamentos do Programa Minimalista (CHOMSKY 1995, 1998, 2000, 2001, 2004), e os pressupostos elaborados dentro da Sociolinguística Variacionista (cf. WEINREICH, LABOV e HERZOG (WLH) (1968); LABOV (1972, 1994, 2000)). Consideramos também estudos posteriores que conciliaram a mudança paramétrica "internalista" da língua (ROBERTS (2007)) com fatores extragramaticais que determinam o percurso das formas linguísticas no tempo histórico (KROCH $(1989,1994,2000))$. Para o estudo da estrutura do DP possessivo usamos a análise sobre os Bare Nouns de Cyrino \& Espinal (2014). Os resultados obtidos mostraram que a média geral de ausência do determinante diante de DPs possessivos se manteve a mesma nos dois períodos analisados, configurando uma variação estável. Concluímos que não houve, portanto, indícios de oscilação no uso de uma ou outra variante que pudesse demonstrar o avanço de uma delas em detrimento de outra.

Palavras-chave: 1. Determinante 2. Possessivo 3. Teoria Gerativa 4. Teoria Variacionista 5. Sintaxe Diacrônica 


\begin{abstract}
GALO, G. D. M. Articles and possessives in the history of Paulista Brazilian Portuguese. Master's thesis. College of Philosophy, Language and Human Sciences, University of São Paulo, São Paulo, 2016.

The aim of this thesis is to describe the possessive DP structure and investigate the use of the determiner in possessive noun phrases in Paulista Brazilian Portuguese from the 19th century. For our description and analysis, we use advertisements and letters from readers and writers drawn from a historical and journalistic corpus. This research tries to verify if there is a parametric change and the contexts affected by the change and to propose an analysis for the observed facts. We adopt a minimalist approach based on Chomsky $(1995,1998,2000,2001$, 2004), within the Principles and Parameters Model (CHOMSKY 1981, 1986). We also adopt a variationist sociolinguistical approach (cf. WEINREICH, LABOV and HERZOG (WLH) (1968); LABOV $(1972,1994,2000)$ ) and studies of "internalist" parametric change (ROBERTS (2007)) and social factors $(\operatorname{KROCH}(1989,1994,2000))$ to determine the way the possible change takes place. In order to explore possessive DP structure we use the Bare Nouns analyses by Cyrino \& Espinal (2014). During the period considered, the use of the article was variable, setting a stable variation.
\end{abstract}

Keywords: 1. Determiner 2. Possessive 3. Generative Theory 4. Variationist Theory 5. Diachronic Syntax. 


\section{SUMÁRIO}

INTRODUÇÃO ......................................................................................................12

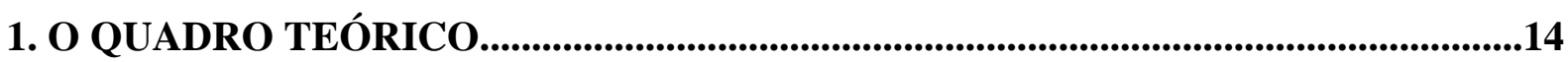

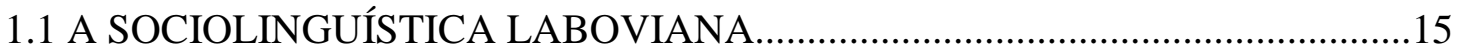

1.1.1 A TEORIA DA VARIAÇÃO NO CONTEXTO DA MUDANÇA

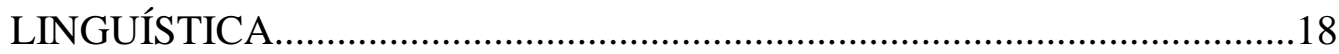

1.1.1.1 O PROBLEMA DA RESTRIÇÃO.............................................20

1.1.1.2 O PROBLEMA DO ENCAIXAMENTO.....................................20

1.1.1.3 O PROBLEMA DA TRANSIÇÃO O...............................................21

1.1.1.4 O PROBLEMA DA AVALIAÇÃO.............................................

1.1.1.5 O PROBLEMA DA IMPLEMENTAÇÃO...................................21

1.1.2 ILUSTRANDO A APLICAÇÃO DA METODOLOGIA LABOVIANA COM UM ESTUDO DE CASO: PEREIRA (2007),........................................22

1.2 A TEORIA GERATIVA E A VISÃO PARAMÉTRICA DA LÍNGUA..............................24

1.2.1 PRESSUPOSTOS DA TEORIA GERATIVA ……………………………....24

1.2.2 A ESTRUTURA DA SENTENÇA E SUAS OPERAÇÕES BÁSICAS...............26

1.2.3 VARIAÇÃO E MUDANÇA SINTÁTICA SOB A PERSPECTIVA

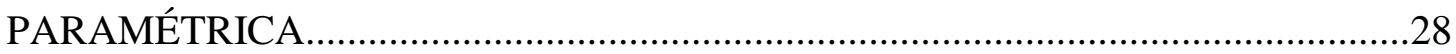

1.2.4 A MUDANÇA PARAMÉTRICA E OS FATORES EXTRALINGUÍSTICOS.....

1.2.5 UM ESTUDO DE CASO: O CLÁSSICO EXEMPLO DO PARÂMETRO DO

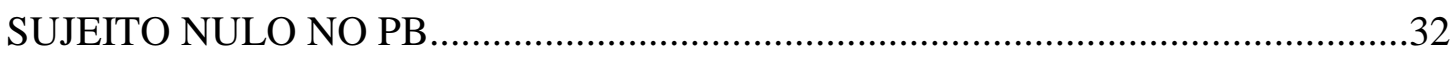

\section{PROPOSTAS DE ANÁLISES PARA UM ESTUDO DO DP POSSESSIVO NO PE E} NO PB.............................................................................................................................................. 38

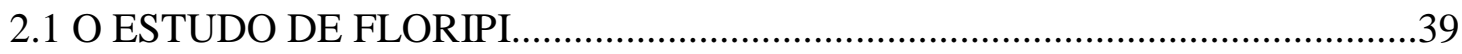

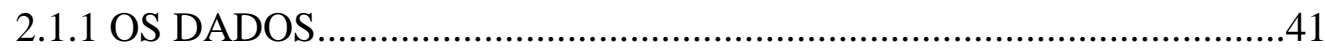

2.1.2 RESULTADOS QUANTITATIVOS......................................................4

2.1.3 GRAMÁTICAS EM COMPETIÇÃO NO PC E AS MUDANÇAS QUE LEVAM ÀS GRAMÁTICAS DO PE.............................................................45

2.1.4 PROPOSTA PARA O PB................................................................. 
2.2. NOVOS DADOS DO CORPUS TYCHO BRAHE: O ESTUDO DE

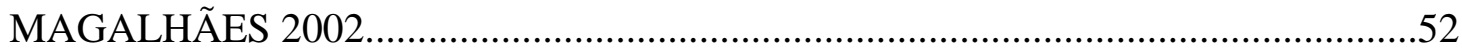

2.3 CASTRO (2006) E O DP POSSESSIVO NO PE E PB........................................53

2.3.1 PARAMETRIZAÇÃO COM BASE EM DIFERENTES LÍNGUAS: O

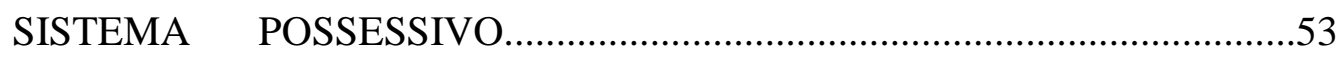

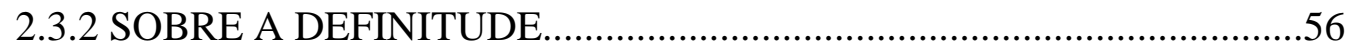

2.4 O ESTUDO DE RINKE: UM PANORAMA DIACRÔNICO DESDE O

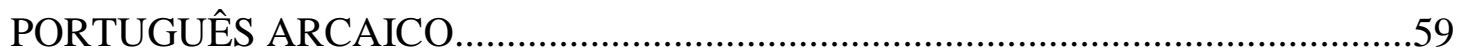

2.5 O ESTUDO DE COSTA (2002): NOVAS INFORMAÇÕES A RESPEITO DO

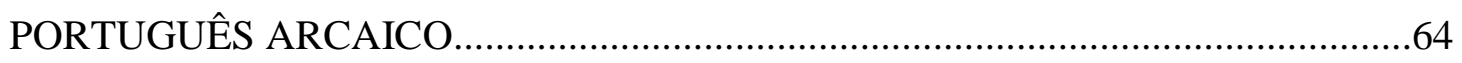

2.3 BRITO (2007) E A ESTRUTURA DO DP......................................................69

3. UMA PROPOSTA DE ANÁLISE PARA O DP POSSESSIVO NO PB ....................... 74

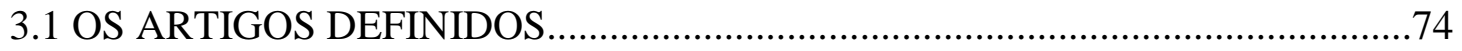

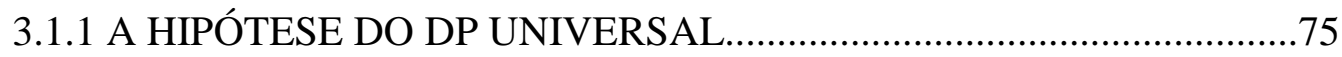

3.1.2 OS ARTIGOS DEFINIDOS E A NOÇÃO DE DEFINITUDE................76

3.1.3 O PARÂMETRO SEMÂNTICO DE CHERCHIA (1998) ......................77

3.1.4 UMA PROPOSTA PARA OS BNS NO PB ........................................78

3.1.5 CONCORDÂNCIA VARIÁVEL DE NÚMERO NO INTERIOR DA

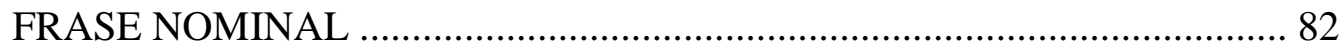

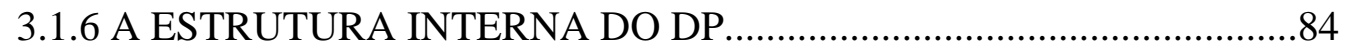

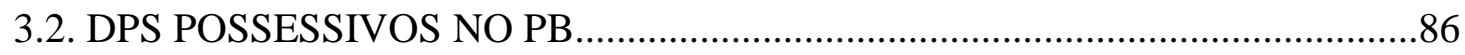

3.2.1 UMA PROPOSTA DE ANÁLISE PARA A ESTRUTURA DO DP POSSESSIVO NO PB .87

3.2.1.1 A NATUREZA CATEGORIAL DOS POSSESSIVOS PRÉ-

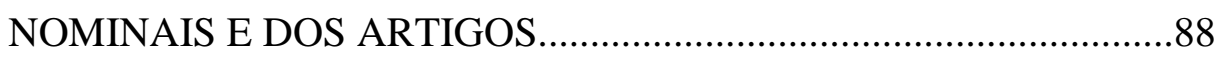

3.2.2 UMA PROPOSTA PARA O DP POSSESSIVO NO PE. .91

4. METODOLOGIA E RESULTADOS QUANTITATIVOS........................................92

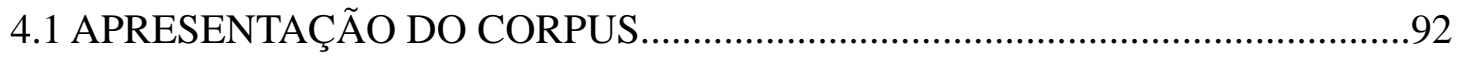

4.2 FONTE DOCUMENTAL E FATORES LINGUÍSTICOS................................. 97

4.3 APRESENTAÇÃO DA VARIÁVEL DEPENDENTE E DAS VARIÁVEIS

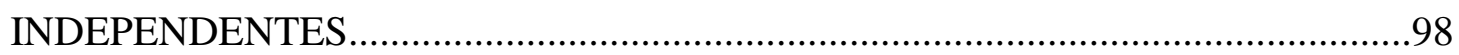

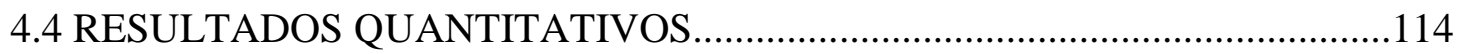


4.4.1 PRESENÇA X AUSÊNCIA DO DETERMINANTE DIANTE DO

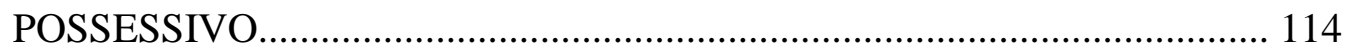

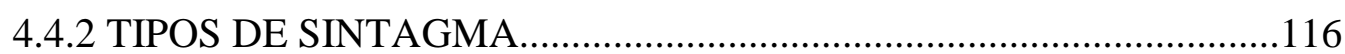

4.4.2.1 DP POSSESSIVO SEM PREPOSIÇÃO................................117

4.4.2.2 DIFERENTES TIPOS DE PREPOSIÇÃO INTRODUTORAS

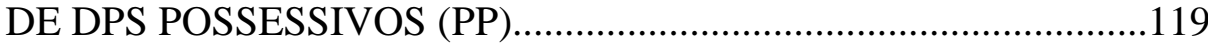

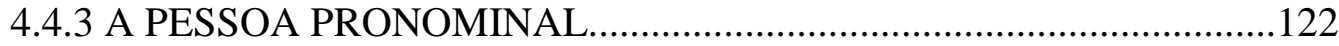

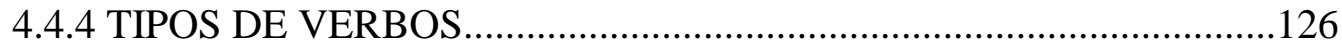

4.4.5 FUNÇÃO SINTÁTICA DO SINTAGMA...........................................131

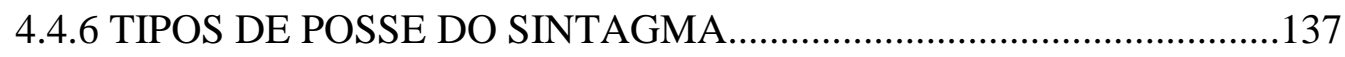

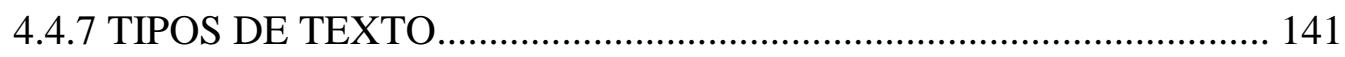

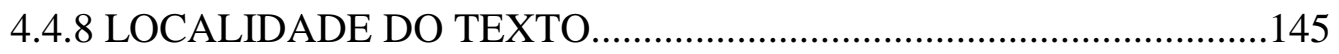

4.5 CONSIDERAÇÕES FINAIS SOBRE OS RESULTADOS APRESENTADOS .....

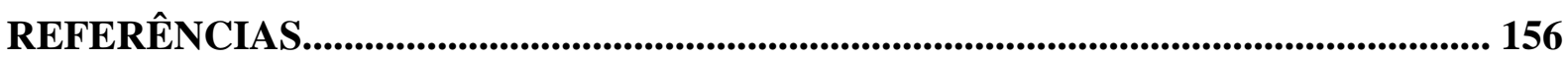

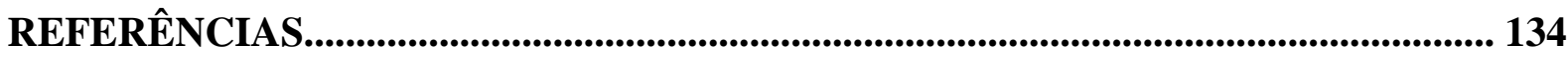




\section{INTRODUÇÃO}

Nesta dissertação, nosso objetivo principal é discutir uma proposta de análise para a variação no uso do determinante em estruturas com possessivos pré-nominais numa perspectiva comparativa entre o português brasileiro $(\mathrm{PB})$ e o português europeu (PE). O estudo prioriza as formas possessivas de $3^{\text {a }}$ pessoa seu, sua, seus, suas, e tem ainda uma dimensão dialetal e diacrônica, uma vez que toma como base empírica um corpus composto por anúncios e cartas de leitores e redatores extraídos de jornais paulistas ao longo do século XIX. Esse corpus jornalístico faz parte do acervo documental construído no âmbito do projeto temático de equipe Para a História do Português Paulista (PHPP), o qual, por sua vez, é um desdobramento de um projeto mais abrangente, denominado Para a História do Português Brasileiro (PHPB), ambos com sede na Universidade de São Paulo.

A dissertação está estruturada em quatro capítulos além de uma conclusão

No capítulo 1, dividido em duas seções maiores, temos como objetivo apresentar o quadro teórico dentro do qual se baseia a análise do fenômeno escolhido. Esse quadro contempla os pressupostos de dois modelos teóricos. O primeiro deles é o da teoria dos Princípios \& Parâmetros (CHOMSKY 1981, 1986) incluindo alguns refinamentos do Programa Minimalista (CHOMSKY 1995, 1998, 2000, 2001, 2004). O modelo gerativista oferece ainda a dimensão teórica para se discutir questões de variação e sintaxe diacrônica, proporcionando o diálogo entre uma visão internalista de mudança e os aspectos externos que condicionam o percurso histórico das formas linguísticas, a sua propagação e implementação. A discussão desses aspectos foi encontrada principalmente em ROBERTS (2007) e KROCH (1989, 1994, 2000).

O segundo quadro teórico adotado oferece os pressupostos elaborados dentro da Sociolinguística Variacionista (cf. WEINREICH, LABOV e HERZOG (WLH) (1968); LABOV (1972, 1994, 2000)).

No capítulo 2 buscamos focalizar a nossa atenção em alguns trabalhos relevantes aos nossos objetivos. Dialogamos e destacamos os pontos principais das propostas de Floripi (2008), Magalhães (2002), Rinke (2010), Costa (2002), Brito (2007) e Castro (2006). As autoras que estudaram o PE verificaram, de maneira geral, o percurso da história do português a partir do século XIII até o século XIX, notando uma mudança gramatical nos padrões de aplicação do determinante com formas possessivas em posição pré-nominal, no interior do sintagma determinante (DP). 
A partir dos dados, as autoras mostram que dos séculos XVI ao XVII, dois sistemas gramaticais co-ocorriam na língua: um com a obrigatoriedade no uso do artigo definido diante do possessivo e outro em que o mesmo não era realizado. A partir do século XVIII a obrigatoriedade no uso do determinante torna-se categórica. Cada autora traz importantes análises e contribuições para o entendimento do nosso fenômeno.

Por sua vez, no capítulo 3, com base em Torres Morais (em preparação), assumimos uma proposta de análise dos DPs possessivos, que parte das hipóteses para a sintaxe e semântica dos Nomes Nus (Bare Nouns- BNs), no PB, tal como desenvolvida em Cyrino \& Espinal (2014). O capítulo está dividido em duas seções maiores. Na seção 3.1, fazemos uma revisão dos pontos relevantes da proposta de C\&E (2014). Na seção 3.2, apresentamos os aspectos centrais da proposta de Torres Morais (em preparação).

Quanto ao capítulo 4, o objetivo geral é apresentar resultados de nossa abordagem quantitativa referentes à variação na colocação dos artigos definidos em sintagmas nominais com formas possessivas de $3^{\mathrm{a}}$ pessoa, seu, sua, seus suas, em posição pré-nominal. Para tanto, ele foi estruturado de modo a contemplar seções e subseções, nas quais apresentamos o corpus jornalístico, a fonte documental e fatores linguísticos de análise, os resultados quantitativos quanto à presença versus ausência do determinante diante do possessivo e o cruzamento com fatores como tipos de sintagma, a pessoa pronominal, tipos de verbos, função sintática do sintagma, tipos de posse do sintagma, tipos de texto e localidade do texto. O capítulo se encerra com as considerações sobre os resultados obtidos.

Por fim, nas conclusões destacamos os aspectos que pensamos poderão oferecer uma contribuição tanto no nível empírico, quanto teórico, para um melhor entendimento do fenômeno abordado. 


\section{O QUADRO TEÓRICO}

Neste capítulo, temos como objetivo apresentar o quadro teórico no qual a análise do fenômeno escolhido será baseada. Esse quadro contempla os pressupostos de dois modelos teóricos: a teoria dos Princípios \& Parâmetros (CHOMSKY 1981, 1986) incluindo alguns refinamentos do Programa Minimalista (CHOMSKY 1995, 1998, 2000, 2001, 2004), e os pressupostos elaborados dentro da Sociolinguística Variacionista, também denominada Sociolinguística Laboviana (cf. WEINREICH, LABOV E HERZOG (WLH) (1968); LABOV (1972)), considerando ainda estudos posteriores que conciliaram a mudança paramétrica “internalista” da língua (ROBERTS (2007)) com fatores extragramaticais que determinam o percurso das formas linguísticas no tempo histórico (KROCH $(1989,1994,2000)$ ).

O capítulo 1 está dividido em duas grandes partes: na primeira, organizada em subseções, trazemos os conceitos básicos que levam ao conhecimento da Sociolinguística Laboviana, entre eles as noções de variedade, variação, variável e variante, incluindo as noções de variável dependente e variáveis independentes - também denominados de fatores condicionadores (cf. seção 1.1). Na seção 1.1.1 discutimos a teoria da variação no contexto da mudança linguística, dando ênfase ao estudo de WLH (1968). Após apresentarmos os moldes da teoria da Sociolinguística Laboviana, na seção 1.1.2 ilustramos a aplicação da metodologia com um estudo de caso. Trata-se do estudo de Pereira (2007), o qual relata um fenômeno de variação e mudança em curso no uso dos pronomes reflexivos no português popular falado em São Paulo.

$\mathrm{Na}$ segunda parte, também organizada em subseções, apresentamos a investigação gerativa da linguagem humana, os principais pressupostos da Teoria dos $\mathrm{P} \& \mathrm{P}$ e a visão paramétrica da língua (cf. seção 1.2.1). Nela descrevemos noções como Língua-I, Língua-E, Gramática Universal (GU), dados linguísticos primários (DLP), princípios universais e fixação de parâmetros. Na seção 1.2.2, a estrutura da sentença e suas três operações básicas (concatenar, mover e concordar) são apresentadas a partir do quadro do Programa Minimalista. Já na seção 1.2.3, baseando-nos em Roberts (2007), mostramos um pouco sobre a variação e a mudança sintática, a partir das noções de reanálise abdutiva, input, mudança paramétrica e a forma como se instaura na língua. Por sua vez, na seção 1.2.4 discutimos melhor aspectos da mudança paramétrica e fatores extralinguísticos, a partir da associação da visão internalista da mudança e a pesquisa variacionista. Para tanto, como veremos no capítulo 4, aplicaremos essa metodologia, buscando identificar resultados quantitativos da frequência do artigo diante do possessivo, descrevendo os fatores que condicionam seu uso. 
E, finalmente, apresentamos um estudo de caso com o clássico exemplo do Parâmetro do Sujeito Nulo no PB (cf. seção 1.2.5).

\subsection{A Sociolinguística Laboviana}

Alguns pesquisadores têm afirmado que a sociolinguística, como um campo especializado na linguagem e sociedade, pode ser dividida em duas perspectivas principais. A primeira delas, denominada macrossociolinguística, assume a sociedade e língua como um todo, contemplando suas consequências no mundo econômico, politico, etc. A segunda, denominada microssociolinguistica, considera os efeitos dos fatores sociais sobre as estruturas linguísticas, utilizando-se de uma metodologia quantitativa sofisticada para determinar fatores condicionantes na aplicação de regras (cf. MONTEIRO, 2000: cap. 2). A segunda perspectiva é comumente denominada de Sociolinguística Laboviana ${ }^{1}$. Como se sabe, Weinreich, Labov e Herzog (1968), em seu trabalho clássico "Fundamentos empíricos para uma teoria da mudança linguística", lançam os fundamentos para uma teoria de variação e mudança empiricamente orientada, posteriormente desenvolvida por Labov (1972).

Com os autores, a noção da língua como fenômeno social dinâmico cuja variação é explicada por forças externas ao sistema volta a ganhar força. Não se vê mais, portanto, a língua do indivíduo (idioleto) como objeto de análise e sim a língua do grupo social no âmbito da comunidade de fala.

No que se segue, apresentaremos em maiores detalhes as noções básicas, tais como: variedade, variação, variável e variante, que são fundamentais para que possamos compreender melhor como atua a abordagem da sociolinguística variacionista.

Variedade, também conhecida como dialeto e falar, é entendida como a fala característica de determinados grupos a partir de diferentes critérios, entre eles: critérios sociais e geográficos, incluindo aqueles mais específicos, como profissão, hábitos, etc. Um deles tem sido reconhecido com grande interesse nos estudos sobre o PB, a saber, o que delimita a variedade culta da variedade popular.

A variedade culta está associada ao grupo de falantes de maior prestígio social, pertencentes à camada mais alta da sociedade, com maior nível de escolarização e maior poder aquisitivo. Um ponto relevante no estudo da variedade culta é o de que a mesma

\footnotetext{
${ }^{1}$ A teoria também é conhecida por outros nomes, como Sociolinguística Variacionista, Sociolinguística Quantitativa e Teoria da Variação e Mudança Linguística.
} 
também apresenta um continuum de variações, como tem sido revelado nos diferentes projetos sobre a gramatica do português culto falado no Brasil, entre eles o da norma urbana culta (NURC).

A variação linguística, por sua vez, é entendida como requisito ou condição do próprio sistema linguístico, inerente às línguas e essencial à própria natureza da linguagem humana. Trata-se de um processo pelo qual duas formas com o mesmo valor referencial, isto é, com o mesmo significado, podem co-ocorrer no mesmo contexto. Há variação nos diversos níveis da gramática: fonológico, morfológico, sintático, lexical e discursivo.

Muitos estudos têm mostrado que o PB apresenta inúmeros fenômenos em variação. Um deles trata das realizações do objeto direto - pronome nominativo e clíticos - (Encontrei

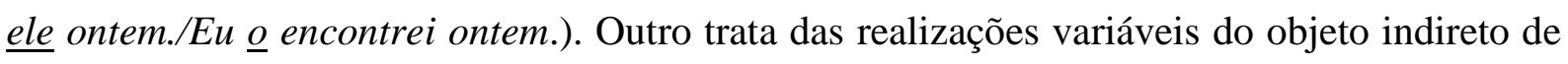
terceira pessoa, ora realizado como clíticos ora como pronomes oblíquos - (Encontrei o Pedro e lhe dei o dinheiro./Encontrei o Pedro e dei o dinheiro para ele.). E ainda, podemos exemplificar com o fenômeno que estudaremos nesta dissertação, que é o da alternância na realização do artigo definido antes de DPs possessivos (Paula lava ( $\underline{\text { s }}$ ) seus cabelos com o shampoo Pantene).

Agora, qual seria a distinção entre variação e variável? Segundo Labov (1972), variável é o lugar na gramática em que se localiza a variação. Para se definir uma variável linguística é necessário:

(i) definir o número exato de variantes;

(ii) estabelecer a multiplicidade de contextos em que ela aparece;

(iii) elaborar um índice quantitativo que mensura os valores das variáveis.

Pelos itens acima especificados, notamos que na definição da variável é importante incluirmos o conceito de variante. Dentro da sociolinguística, variantes são as formas individuais que competem pela expressão da variável, por exemplo: a presença versus a ausência do artigo diante do DP possessivo. Portanto, para se estabelecer o conceito de variável linguística é necessário que duas ou mais variantes tenham o mesmo significado referencial.

As variantes mais conhecidas em todas as línguas são as variantes padrão e não padrão. A variante padrão é a variante de prestígio, conservadora, que pertence à variedade culta da língua. Já a variante não padrão é o oposto da padrão, é considerada estigmatizada e inovadora, usada em contextos menos formais. 
Nem todas as variantes recebem essa avaliação. No caso da presença versus ausência do artigo definido com DPs possessivos no PB, tal avaliação entre um forma conservadora ou inovadora não se aplica. Entretanto, como veremos no capítulo II, na história do PE ao longo dos séculos, o uso dos artigos diante dos possessivos se torna categórico. Isso não impede, porém, como os estudos quantitativos têm mostrado, que haja variação na fala e escrita dos falantes cultos brasileiros.

De maneira geral, a análise sociolinguística enfoca o processo de interação fala/sociedade de uma dada variedade, buscando compreender a variável e os fatores que influenciam a operação de uma ou de outra variante, estabelecendo uma sistematização ao processo de variação linguística.

Vale ainda ressaltar que, para Labov (1972), somente há atribuição de valor social às regras linguísticas quando existe variação. Isso ocorre, pois, os falantes não estão acostumados a aceitar que duas expressões distintas signifiquem exatamente a mesma coisa, preferindo a significados diferentes e não iguais e em competição.

Uma consequência natural da forma de avaliação das variedades linguísticas envolve um continuun de distinção entre elas, tendo como extremos a fala popular (vernacular) e a norma culta. Porém, não basta reconhecer a variação por si só em seu contexto, é necessário explicá-la, identificar os meios que a controlam e inseri-la dentro de um modelo de linguagem, entendendo seu sistema e suas relações.

Logo, ao analisarmos as causas da mudança sintática, é necessário saber em que camada da estrutura social ela se originou, de que forma se difundiu para outros grupos sociais e quais os grupos que se mostraram resistentes a ela. Identificar os meios pelos quais as formas variantes de uma variável entram em disputa pela expressão de um significado é o que viabiliza a determinação dos condicionadores (ou fatores condicionantes) linguísticos e sociais, que configuram o objetivo principal de uma análise sociolinguística.

Ao afirmar que há fatores condicionantes na variação, afirma-se também que a variação linguística não é aleatória, que não acontece ao acaso e que existem regras que a regem, forças dentro e fora da língua que fazem um grupo de pessoas ou um único indivíduo falar da maneira como fala.

Esses condicionadores são os fatores que regulam/condicionam nossa escolha entre uma ou outra variante e podem ser divididos em internos e externos. Os condicionadores internos são os linguísticos, também chamados de variáveis independentes e tendem a estar relacionados com mudanças graduais. Os condicionadores externos, por sua vez, são os 
extralinguísticos, também chamados de variáveis independentes (ou grupo de fatores). São do tipo catastrófico e tendem a provocar mudanças linguísticas abruptas.

\subsubsection{A teoria da variação no contexto da mudança linguística}

A noção de que a língua se apresenta como um sistema organizado, mas heterogêneo, ou seja, formado por regras categóricas e regras variáveis, torna-se muito importante no estudo da mudança linguística.

A heterogeneidade estruturada da língua permite depreender, a partir das regras variáveis, os padrões linguísticos, sociais e estilísticos comportamentais que atuam na dinâmica da mudança.

Vale ressaltar que, na teoria laboviana, é reconhecida a noção de competência linguística, a qual é entendida como a capacidade do falante lidar com a heteregeneidade do sistema. Ou seja, a língua comporta regras variáveis permitindo que um falante $A$ aprenda uma forma usada por um falante $B$ e a adote como sua, sem abandonar a forma que usava. Por conseguinte, não existe falante de estilo único.

Weinreich, Labov e Herzog (1968) propõem um mecanismo na língua que não envolve a simples troca de uma forma linguística pela outra, mas a coexistência delas sob alternância em uma mesma comunidade, possíveis na fala de uma mesma pessoa inclusive, em que há o desfavorecimento gradual de uma forma pela outra através de motivações sociais, em situação de competição.

No estudo da mudança linguística, embora a Sociolinguística se dedique ao tratamento das regras variáveis, é preciso considerar que todas as línguas possuem regras categóricas, as quais, em outros quadros teóricos como a gerativa, são relevantes para se entender a natureza da competência linguística do falante nativo.

No PB podemos trazer como exemplo algumas regras categóricas:

(i) Ordem SV no contexto de verbos transitivos diretos (ex.: o José comprou a casa, mas não *comprou o José a casa.)

(ii) Ordem preposição mais complemento (ex.: com a Maria, mas não *a Maria com)

(iii) $\mathrm{O}$ artigo antecede o nome (ex.: o livro, mas não *livro o)

(iv) A ordem auxiliar mais verbo principal (ex: o José tinha saído, mas não *o José saído tinha). 
Segundo WLH (1968), a mudança linguística não afeta a estrutura da língua, ou seja, a língua continua estruturada enquanto as mudanças ocorrem. A partir do sistema da heterogeneidade ordenada, a competência dos falantes mostra-se inerente e o germe da mudança está no processo de transmissão da língua de uma geração a outra. Logo, fenômenos desviantes na fala da comunidade se tornam fenômenos constantes na gramática das crianças.

Porém, a mudança linguística não está vinculada a sucessão de gerações. Ela se dá por um continuum entre as gerações de uma certa comunidade de forma não uniforme que segue diferentes rumos. A história do $\mathrm{PB}$, quando comparada a história do $\mathrm{PE}$, nos oferece um exemplo de mudança em diferentes direções de vários fenômenos linguísticos.

Um ponto importante a ser destacado é que as formas linguísticas destacam além dos significados linguísticos, os significados sociais. A consequência disso é que a valoração social de uma variante em relação a outra tem o poder de acelerar ou barrar uma mudança na língua, entre outros fatores.

Vale ressaltar ainda que a Teoria da Variação prioriza como objeto de estudo a comunidade de fala, não o indivíduo. Dessa forma, se torna muito importante entender o conceito de comunidade de fala. Segundo Labov (1972), uma comunidade de fala não é apenas um grupo de falantes que usa as formas da língua, mas um grupo de falantes que, além disso, compartilha as mesmas normas a respeito do uso dessa língua. Isso significa que muitas vezes os falantes têm consciência desses usos e são capazes de emitir juízos de valor sobre as formas variáveis.

Muitas vezes, na realidade linguística brasileira, essa avaliação das variantes é marcante na produção linguística dos falantes letrados, uma vez que, ao lado da variante adquirida na fase de aquisição da língua materna, existe a forma aprendida em situação de escolaridade. Isso leva o falante culto a ter consciência estilística e social do uso de cada uma delas (não de forma total, mas consciente) ${ }^{2}$.

Dessa forma, mudanças podem ocorrer a todo o momento, ainda que sejam imperceptíveis. Mas como elas ocorrem? Como já visto anteriormente, WLH (1968) mostram que é possível que, em seu repertório linguístico, um falante disponha de mais de uma forma para expressar o mesmo significado - situação caracterizada por variação linguística. Porém, pode acontecer um desfavorecimento gradual da forma original e o favorecimento da nova, de

\footnotetext{
${ }^{2}$ Para uma discussão sobre a "Gramática do Letrado", cf. Kato (2005). Embora a reflexão se dê dentro do quadro teórico gerativista, encontra paralelo na concepção de variação linguística laboviana.
} 
modo que a forma antiga deixe de ser usada. Nesse caso, a situação já virou um processo de mudança linguística.

Portanto, a generalização da mudança através da estrutura linguística não é uniforme nem instantânea. Os fatores linguísticos e sociais encontram-se intimamente relacionados no desenvolvimento linguístico e, de maneira geral na língua, nem tudo que varia sofre mudança, mas toda mudança pressupõe variação (cf. WLH (1968)).

No entanto, duas variantes competindo podem conviver em variação durante anos sem que haja a substituição de uma pela outra forma, ou seja, sem que o processo de mudança se concretize, caracterizando uma variação estável: é o que ocorre em Pereira (2007), em seu estudo sobre os reflexivos na língua falada popular. Como afirma a autora, é possível que uma das formas do fenômeno estudado esteja caminhando em direção ao desaparecimento em um ritmo tão lento que o intervalo de tempo proposto pelo corpus não seja suficiente para transparecer qualquer tendência. Neste ponto, a autora assume com Labov $(1994,2001)$ que a mudança diminui sua velocidade quando está perto de completar-se, podendo envolver longos períodos sem chegar a um termo final. Apresentaremos em maiores detalhes Pereira (2007) na seção 1.1.3.

Voltando ao estudo de WLH (1968), vemos que os autores adotam um aspecto restritivo formal, embora sem aderir à noção de homogeneidade tal como proposta na gramática gerativa. Parece que a preocupação mais importante para uma teoria de mudança linguística é expressa em um conjunto de fundamentos empíricos, envolvendo cinco problemas que devem ser resolvidos no estudo da variação ${ }^{3}$ :

(i) Restrição ou Fatores Condicionantes;

(ii) Encaixamento da variação;

(iii) Avaliação das mudanças;

(iv) Transição;

(v) Implementação.

\footnotetext{
${ }^{3}$ Para compreender melhor o estudo clássico de WLH (1968) neste aspecto, baseamo-nos no roteiro proposto em Coelho \& al (2015).
} 


\subsubsection{O problema da Restrição}

Esse problema tem como objetivo investigar as mudanças que ocorrem nas línguas e as condições, ou princípios, que favorecem a sua ocorrência, definindo os fatores linguísticos (internos) e sociais (externos) que motivam o uso de uma ou outra variante. É importante observar que os princípios não são categóricos, mas apontam para tendências gerais. Dessa forma, são os fatores condicionantes que devem ser buscados no estudo da mudança. Assim, o controle dos grupos de fatores linguísticos e extralinguísticos que se aplica aos fenômenos variáveis é que nos permitirá reconhecer o conjunto das mudanças possíveis e das condições a que elas se submeteram.

\subsubsection{O problema do Encaixamento}

O problema do encaixamento envolve reconhecer a forma como um fenômeno linguístico em variação ou mudança está encaixado tanto na estrutura linguística como na social, ou seja, o encaixamento está ligado à forma com que um fenômeno variável se relaciona a outros fenômenos.

Há, portanto, uma relação entre o fenômeno variável e os condicionadores linguísticos e extralinguísticos que atuam como contextos de restrição, favorecendo ou desfavorecendo a aplicação de determinada regra. Em geral, uma mudança começa nos contextos linguísticos que mais favorecem a aplicação da regra e se difunde progressivamente aos demais contextos. O estudo do encaixamento tem tido grande prioridade na teoria laboviana. Os pesquisadores têm reconhecido que os fenômenos em mudança se encaixam no sistema sem que ele precise mudar por completo, ou seja, o sistema continua estruturado enquanto muda, de forma que os falantes continuam se comunicando sem prejuízo e sem comprometer a estruturalidade do sistema.

É possível afirmar, portanto, que é somente a partir da observação sistemática de diferentes fenômenos variáveis e de diferentes condicionadores atuando sobre um mesmo fenômeno é que poderemos avaliar como uma mudança se encaixa na estrutura linguística e na social. 


\subsubsection{O problema da Transição}

O problema da transição busca compreender melhor o período e os estágios em que as variantes coexistem ao longo das diferentes gerações e o tempo em que uma das formas avança sobre a outra entre os grupos sociais. Ou seja, procura-se compreender como se propagam as formas em variação/mudança, passando de um estágio a outro.

Portanto, para responder sobre o problema de transição, deve-se estar atento aos estágios da natureza linguística e extralinguística envolvidos no processo de variação/mudança.

\subsubsection{O problema da Avaliação}

O problema da avaliação tem por objetivo verificar os efeitos da atitude subjetiva e consciente do falante em relação às formas linguísticas em variação/mudança. Como se sabe, a avaliação linguística das formas está associada ao uso linguístico, ou seja, a sua eficiência no contexto da comunicação e interação social. Segundo essa perspectiva, os falantes têm competência linguística para compreender e usar diferentes variantes levando em conta uma distinção entre variantes de maior e de menos prestígio. A primeira, associada aos usos mais formais e a segunda aos usos mais informais.

\subsubsection{O problema da Implementação}

O problema de implementação analisa de perto os fatores envolvidos na implementação da mudança e a razão pela qual as mudanças ocorrem em determinada língua em um dado momento, mas não em outra, ou na mesma língua, em outros períodos.

Vale ressaltar que todos esses problemas estão intimamente relacionados, ou seja, é a implementação que verifica a necessidade de identificar condições possíveis para a mudança (restrição), os fatores condicionadores e o encaixamento estrutural e social do fenômeno em variação/mudança (encaixamento) e os estágios de transição atravessados pelas atitudes subjetivas do falante (avaliação). 


\subsubsection{Ilustrando a aplicação da metodologia laboviana com um estudo de caso: Pereira (2007)}

Para ilustrar a aplicação da teoria laboviana, trazemos um estudo de caso com base no trabalho de Pereira (2007). Nesse estudo, a autora tem como objetivo estudar a variação e provável mudança em curso no uso dos pronomes reflexivos no português popular falado na cidade de São Paulo, a partir de uma abordagem sociolinguística, funcionalista e cognitivista, buscando comprovar ou refutar a tese da mudança e estabelecer os fatores que favorecem ou desfavorecem o seu desenvolvimento.

A autora parte da hipótese de que os pronomes reflexivos estão em uso de uma forma variável no português popular, caracterizando um processo de mudança que tende a ir em direção ao seu apagamento. Porém, mesmo havendo um intervalo de dez anos entre os dois conjuntos de dados colhidos pela autora, a conclusão a que ela chega é a de que não houve mudança - o índice de uso do pronome foi praticamente o mesmo nos dois corpura (40\% nos inquéritos de 1986/87 e 42\% nos de 1997 a 2001).

Seguindo a metodologia da Sociolinguística Variacionista Laboviana, a autora estabeleceu os fatores que poderiam favorecer ou desfavorecer o uso de uma forma anafórica explícita em estruturas reflexivas, recíprocas e passivas. Confira o quadro abaixo: 


\begin{tabular}{|l|c|c|}
\hline Fatores selecionados & $\begin{array}{c}\text { Corpus de } \\
\mathbf{1 9 8 6 - 1 9 8 7}\end{array}$ & $\begin{array}{c}\text { Corpus de } \\
\mathbf{1 9 9 7 - 2 0 0 1}\end{array}$ \\
\hline SEMÂNTICOS & & \\
\hline Tipo de pronome reflexivo (Rodrigues; Pereira, 2006) & $\mathrm{X}$ & $\mathrm{X}$ \\
\hline Classe semântica do verbo (Kemmer, 1993) & & $\mathrm{X}$ \\
\hline SEMÂNTICO-COGNITIVOS & & \\
\hline Tipo de evento causativo (Talmy, 2003a,b) & & \\
\hline Divisão da psique (Lakoff, 1996) & $\mathrm{X}$ & $\mathrm{X}$ \\
\hline Dinâmica de força (Talmy, 2003a,b) & $\mathrm{X}$ & $\mathrm{X}$ \\
\hline Natureza do evento conforme o número de participantes & $\mathrm{X}$ & $\mathrm{X}$ \\
\hline Domínio do evento & & $\mathrm{X}$ \\
\hline & & $\mathrm{X}$ \\
\hline SINTÁTICOS & & \\
\hline Função sintática da forma anafórica & $\mathrm{X}$ & $\mathrm{X}$ \\
\hline Estatuto gramatical do pronome (Borba, 1991) & $\mathrm{X}$ & $\mathrm{X}$ \\
\hline Paralelismo & $\mathrm{X}$ & $\mathrm{X}$ \\
\hline Pessoa do discurso & $\mathrm{X}$ & \\
\hline Polaridade & & \\
\hline DISCURSIVOS & & \\
\hline Status informacional do referente & $\mathrm{X}$ & $\mathrm{X}$ \\
\hline
\end{tabular}

\begin{tabular}{|l|c|c|}
\hline SOCIAIS & & \\
\hline Procedência & $\mathrm{X}$ & \\
\hline Escolaridade & $\mathrm{X}$ & \\
\hline Favela & $\mathrm{X}$ & $\mathrm{X}$ \\
\hline
\end{tabular}

Quadro 1.1: Fatores selecionados como significativos pelo programa estatístico

(PEREIRA (2007:244)) $)^{4}$

Como condicionadores internos, Pereira (2007) apresenta os fatores de natureza semântica (tipo de pronome reflexivo, classe semântica do verbo), de natureza semânticacognitiva (tipo de evento causativo, divisão da psique, dinâmica de força, natureza do evento conforme o número de participantes, domínio do evento), de natureza sintática (função sintática da forma anafórica, estatuto gramatical do pronome, paralelismo, pessoa do discurso, polaridade) e de natureza discursiva (status informacional do referente). Como

\footnotetext{
${ }^{4}$ Pereira (2007:244), quadro 10 no original.
} 
condicionadores externos a autora apresenta os fatores de natureza social (procedência, escolaridade, de qual favela é proveniente, idade).

O estudo de Pereira vai ser muito relevante para essa dissertação, como veremos no capítulo 4, uma vez que trata de um fenômeno de variação estável, que acreditamos ser a característica do fenômeno que estamos analisando.

\subsection{A Teoria Gerativa e a visão paramétrica da língua}

\subsubsection{Pressupostos da Teoria Gerativa}

Um dos quadros teóricos adotados na nossa dissertação é o da Teoria Gerativa, que busca compreender, descrever e explicar a natureza da linguagem humana. A partir desse objetivo, os linguistas se esforçam a elaborar respostas às seguintes perguntas que permeiam os estudos sobre a língua:

1) Em que consiste o conhecimento linguístico existente na mente das pessoas?

2) Como esse conhecimento é adquirido pela criança já nos primeiros anos de vida?

3) Como esse conhecimento é posto em uso, em situação real, pelos indivíduos?

4) Como esse conhecimento é produzido pelo cérebro humano?

A neurolinguística se encarrega de responder a última questão, ocupando-se do cérebro humano e seu sistema físico, químico e biológico que dão origem ao fenômeno da linguagem na mente humana.

As demais questões, principalmente as duas primeiras, são objetos de estudo dos linguistas gerativos, que propõem uma teoria geral a respeito de como a linguagem funciona na mente humana, formulando hipóteses sobre como deve ser o conhecimento linguístico existente na mente das pessoas.

Essa linha de investigação gerativa da linguagem humana, que considera a capacidade de adquirir uma língua como um componente da mente, foi inaugurada na década de 1950, com os trabalhos do linguista, filósofo e ativista político Noam Chomsky. Em 1957, o autor lança seu livro clássico "Estruturas sintáticas", em que levanta sua primeira hipótese sobre os procedimentos mentais que geram as estruturas da linguagem. 
Em estudos posteriores, Chomsky $(1981,1986)$ trata a primeira questão nos seguintes termos: o conhecimento linguístico internalizado na mente dos falantes é um conhecimento implícito, uma capacidade de natureza mental interiorizada no cérebro humano que torna possível a um indivíduo nativo compreender e produzir uma sentença e reconhecer se a sentença é aceitável ou não em sua própria língua. Esse conhecimento implícito, essa gramática internalizada do falante foi inicialmente chamada de competência linguística e posteriormente renomeada Língua-I. A competência linguística, ou Língua-I, se opõe à noção de desempenho, ou Língua-E, que, por sua vez, designa os produtos gerados, o conjunto de sentenças possíveis de serem determinadas por esse sistema interno (Língua-I). Chomsky tem afirmado constantemente que a Língua-I é o objeto principal de investigação linguística. No entanto, para descrevermos e explicitarmos as suas propriedades, necessitamos dos dados da Língua-E.

E como esse conhecimento é adquirido pela criança já nos primeiros anos de vida? Uma resposta a essa questão parte da noção de que para que seja possível a aquisição de uma gramatica particular para a criança postula-se a ideia de órgão mental, um componente genético inato ao ser humano que nos possibilita articular princípios universais linguísticos para o entendimento da linguagem, chamado incialmente de Faculdade da Linguagem e posteriormente de Gramática Universal (GU) (cf. CHOMSKY 1981, 1986).

Se o ser humano não tivesse uma faculdade da linguagem inata, a criança não seria capaz de adquirir a língua da forma como adquire, ainda mais considerando a pobreza de estímulos que ela recebe a partir dos dados linguísticos primários $\left(\mathrm{DLP}^{5}\right)$, acessados de forma inconsciente pela própria criança, em seus anos iniciais de experiência com o mundo.

A GU se caracteriza como um conjunto de princípios rígidos e invariáveis que regulam o funcionamento da gramática como um todo e estão presentes em todas as gramáticas possíveis das línguas. No entanto, como dar conta das diferenças entre as línguas? Ou mesmo entender a variação e mudança sintáticas numa dada língua? Associado aos Princípios invariáveis postula-se um conjunto de informações flexíveis, abertas para serem fixadas a partir da experiência que cada indivíduo tem com uma língua particular. Esse conjunto limitado ficou conhecido como Parâmetros e são eles que possibilitam entender as diferenças, variações e mudanças nas línguas (cf. CHOMSKY 1981, 1986).

Dessa forma, os parâmetros complementam a resposta para a questão 2, uma vez que são fixados pela criança nos primeiros anos de vida, no processo de aquisição da linguagem,

\footnotetext{
${ }^{5}$ Em inglês: Primary Linguistic Data (PLD).
} 
de maneira que ela consiga desenvolver a sua gramática interna a partir de evidências contidas nos DLPs e a partir das propriedades inatas proporcionadas pelas estruturas da GU. Os estímulos desencadeiam a fixação dos valores paramétricos especificados pela GU, definindo a gramática específica da língua adquirida naquela situação (Língua-I). E como é estruturada essa gramática?

\subsubsection{A estrutura da sentença e suas operações básicas}

Vale ainda ressaltar a mais recente reformulação da Teoria dos Princípios e Parâmetros (P\&P), o quadro do Programa Minimalista (CHOMSKY 1995, 2000, 2001, 2004). Esse novo quadro tem por objetivo geral definir um mínimo de operações possíveis e excluir tudo que for desnecessário dentro do modelo, refinando a teoria dos P\&P.

Segundo essa abordagem, as estruturas das línguas são construídas e representadas a partir de três operações fundamentais: Concatenar (Merge), Mover (Move) e Concordar (Agree).

Concatenar é o mecanismo mais importante, que cria e combina as estruturas de forma invariante, juntando diferentes elementos para formar uma instância complexa dentro da estrutura, passível de ser classificada. Logo, ele não faz parte dos processos de mudança ou variação linguística, afinal, ele é considerado um princípio universal em todas as línguas.

É o caso da concatenação de um determinante e um sintagma nominal, por exemplo. O DP (determiner phrase) a toalha é formado por meio da operação concatenar, uma vez que o sintagma nominal toalha combina com o determinante $a$, formando essa unidade maior (DP), em que D $a$ é o núcleo do DP. Se os dois elementos concatenados não sofreram nenhum tipo de movimento dentro da sentença, essa concatenação é externa (se $\alpha$ e $\beta$ são elementos separados e combinam). Mas, se um dos elementos for uma cópia dentro da estrutura da sentença, essa concatenação é interna (se $\beta$ é parte de $\alpha$, sendo $\beta$ uma cópia).

Já a operação Mover é proveniente do processo de concatenar. Quando um constituinte já foi concatenado, mas precisa ser concatenado de novo com outro elemento, acontece um movimento desse constituinte até o local que ele é realizado foneticamente na estrutura, mas deixando traços (ou cópias) nulos fonologicamente pelos lugares que passou.

Um exemplo clássico de movimento são as sentenças com pronomes interrogativos do tipo $O$ que você comprou?. Nesta sentença, o DP interrogativo o que, gerado na posição interna da frase verbal (VP) como complemento do verbo comprar, move-se para uma 
posição na periferia à esquerda da frase, onde é fonologicamente realizado deixando uma cópia na posição em que foi originalmente gerado: O que você comprou fo que\}?

Por fim, a operação Concordar expressa os mecanismos de concordância entre os elementos com características formais da língua, tais como: pessoa, número, gênero e caso. Essa operação permite que um elemento concorde com o outro, de forma que os traços não interpretáveis de um elemento sejam eliminados, permanecendo apenas a estrutura dos traços interpretáveis.

Verifica-se na expressão nominal as meninas bonitas que o traço [+ plural] é realizado morfofonologicamente em todos os elementos. Porém, segundo Chomsky (1999), essa característica é valorada nas línguas apenas no núcleo de SNs (sintagmas nominais). No capítulo 3, discutiremos mais sobre essa noção de concordância de número, sua valoração e sua interpretabilidade.

Se a operação concatenar faz parte dos princípios das línguas por ser invariante, mover e concordar depende das características das línguas individualmente, ou seja, de seus parâmetros. Quando uma mudança/variação linguística acontece, concluímos que ela resultou de mudanças dos valores paramétricos dos traços formais das categorias funcionais, alterando as operações de mover e concordar.

\subsubsection{Variação e mudança sintática sob a perspectiva paramétrica}

Vale ressaltar que a teoria gerativa, como desenvolvida nos primeiros anos e, muitas vezes criticada por tomar como base empírica dados da intuição linguística do falante nativo, através dos julgamentos de gramaticalidade e agramaticalidade, ganha novos e importantíssimos rumos. O trabalho pioneiro de Lightfoot (1979), incorporando os pressupostos da teoria gerativa aos estudos de mudança sintática, ao lado do enorme avanço dos trabalhos de cunho comparativo, envolvendo um amplo leque de línguas das mais diferentes famílias linguísticas, leva ao desenvolvimento da Teoria dos Princípios e Parâmetros como acima especificada.

Ora, uma vez que os parâmetros têm um papel importante na descrição da variação e mudança sintática, há a necessidade de se entender a sua natureza formal. Roberts (2007), sob a perspectiva minimalista, faz uma conexão abrangente entre a abordagem paramétrica da língua e as perspectivas da mudança sintática. Seguindo Borer (1989), o autor assume um pressuposto que se tornou consensual entre os gerativistas, a saber: os elementos sujeitos a variação sempre são definidos em termos das características das projeções funcionais da 
língua. Roberts (2007) traz um refinamento da noção de parâmetro propondo três propriedades formais que devem fazer parte do estatuto de todo parâmetro nas diferentes línguas:

(i) um conjunto de traços formais altamente restritos;

(ii) a especificação de um valor "default";

(iii) a especificação das evidências que possam expressá-lo de forma clara na aquisição e mudança.

A partir dessas propriedades gerais o autor argumenta que o mecanismo central da mudança sintática é a mudança paramétrica, e que esta, por sua vez, se manifesta no processo de reanálise e acontece devido à natureza abdutiva da aquisição da linguagem.

Como Roberts (2007:124) explica, a reanálise abdutiva distingue-se do mecanismo de indução ou de dedução por ser passível de erro. Na elaboração dedutiva, por exemplo, dados o caso, a lei e o resultado, o caso instancia a lei e disso o resultado se segue. $\mathrm{Na}$ indução, o resultado está intrinsicamente associado ao caso, e disso segue-se a lei. Dado o famoso silogismo dedutivo "Todos os homens são mortais" (lei), "Sócrates é um homem” (caso), logo, "Sócrates é mortal” (resultado), no raciocínio abdutivo, uma vez tendo o resultado e a lei, não se pode garantir o caso. Ou seja, na abdução, a conexão entre o caso e o resultado que dele se segue pode ser acidental. A reanálise abdutiva é, pois, um mecanismo que muda a estrutura subjacente de um padrão sintático, porém não implica qualquer alteração da sua manifestação superficial.

Em parte por causa de sua natureza lógica falha, a noção de abdução proporciona uma maneira útil de pensar sobre a reanálise na aquisição da linguagem. De acordo com Andersen (1973:767, apud ROBERTS 2007:227), podemos esquematizar a reanálise abdutiva da seguinte forma:

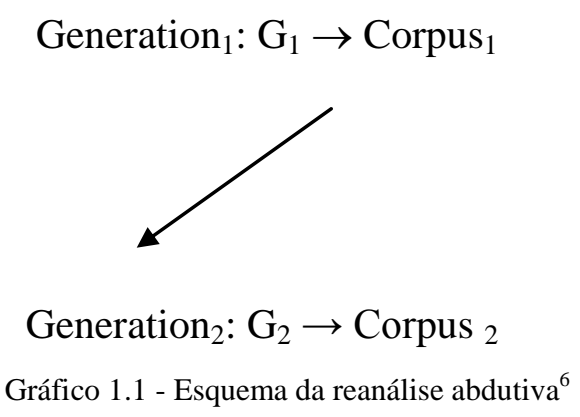

\footnotetext{
${ }^{6}$ Andersen (1973:767, apud ROBERTS 2007:227), sem numeração no orginal.
} 
No gráfico (1.1) acima 'Corpus' refere-se a um conjunto de sentenças produzidas pelos falantes. Isso é chamado de 'Output'; ' $G$ (rammar)' refere-se a uma instanciação da GU com parâmetros definidos pela 'Generation 1', a qual tem a 'G1' subjacente ao 'Corpus 1'. A 'G2' (gramática da criança) deriva do Corpus 1 e da GU, gerando um Corpus 2. Dessa forma, a criança pode fazer um erro, já que se pode pensar na GU como a lei e Corpus 1 como o resultado. Ela pode cometer um erro de abdução e deduzir um caso similar G2 pelo caso real G1.

Não há ligação direta entre $G 1$ e $G 2$, ambas as gramáticas são entidades mentais e não é possível ter acesso direto ao conteúdo da mente do outro. Como dissemos, as gramáticas são transmitidas de uma geração a outra via corpus, que pode dar margem a erros de abdução. A forma da transmissão leva a erros de aprendizagem e este tem sido o ponto de vista geral assumido por muitos: as reanálises são simplesmente erros de abdução.

Dessa forma, a reanálise como sintoma de uma variação/mudança paramétrica pode ser observada em diferentes estudos de sintaxe sincrônica e diacrônica. Nesses estudos, parâmetros são conjuntos de propriedades do sistema gramatical e têm seu valor fixado a partir da informação positiva obtida através do input disponível. Uma vez que os parâmetros unificam os conjuntos de propriedades gramaticais superficiais, isso implica que uma alteração de parâmetro pode se manifestar como um conjunto de reanálises, e uma nova análise é normalmente um sintoma de uma alteração de parâmetro.

Por fim, Roberts afirma que se um parâmetro é expresso nos dados com um determinado valor, este é fixado pelos falantes. Assim, ele propõe que a ambiguidade e opacidade na expressão de um parâmetro são necessárias para que ocorra a mudança abdutiva. A expressão de um parâmetro se torna ambígua quando a estrutura expressa qualquer um de seus valores ou nenhum deles. Por seu lado, a opacidade decorre da complexidade, uma vez que os falantes preferem assinalar a representação estrutural mais simples às sentenças do "input".

\subsubsection{A Mudança Paramétrica e os fatores extralinguísticos}

Roberts (2007) traz uma importante discussão a respeito do fato de que a mudança sintática tem, na verdade, dois aspectos a serem abordados: a mudança paramétrica que ocorre durante o processo de aquisição da linguagem - de forma individualizada - e a propagação da mudança na comunidade linguística. 
De acordo com a Teoria Gerativa a mudança paramétrica apresenta-se a partir de dois aspectos principais:

(i) A mudança paramétrica é catastrófica (instantânea), no sentido em que um determinado parâmetro muda seu valor instantaneamente e irrevogavelmente na fase de aquisição da linguagem;

(ii) A mudança paramétrica é interna ao falante e ocorre, basicamente, de maneira inteiramente independente do meio social, cultural ou histórico do falante. O único fator atuando na aquisição e na mudança é o DLP, o qual expressa os valores paramétricos.

Seria possível conciliar os aspectos internos e externos da mudança? Ora, se reconhecemos que mudanças bem sucedidas se dão através de reanálises abdutivas que se propagam nas comunidades de fala, a reposta é positiva: sim, é possível fazer essa associação.

Como dissemos, a visão internalista da mudança parece estar na contramão da pesquisa variacionista, sem possibilidade de diálogo com os pressupostos da Teoria da Variação e Mudança, tal como desenvolvida por WLH ((1968), Labov (1972) e seus seguidores (cf. seção 1.1)). De acordo com a Teoria Laboviana, a variação é resultado da natureza social da língua, sendo produto e condição para a comunicação. Além disso, o processo de implementação da mudança se apresenta nos dados de forma lenta e gradual, pressupondo períodos (longos ou não) de existência entre as variantes que compõem a variável linguística (cf. TORRES MORAIS \& BERLINCK (2009)).

Kroch $(1989,2000)$ concilia a teoria paramétrica "internalista" com os fatores extragramaticais que determinam o percurso das formas linguísticas no tempo histórico, através de uma metodologia lógico-matemática. Uma vez que entendemos os processos pelos quais uma mudança sintática ocorre, quais seriam os processos pelos quais ela se propaga? Sua resposta envolve a afirmação de que o curso de tempo da mudança sintática é impossível de ser fixado a um único ou específico momento histórico. A forma como as mudanças paramétricas se manifestam nos textos históricos não corrobora a hipótese de que sejam instantâneas. Ao invés disso, elas seguem normalmente uma curva- $S$, que mostra a gradação da mudança paramétrica, como mostra a figura abaixo: 


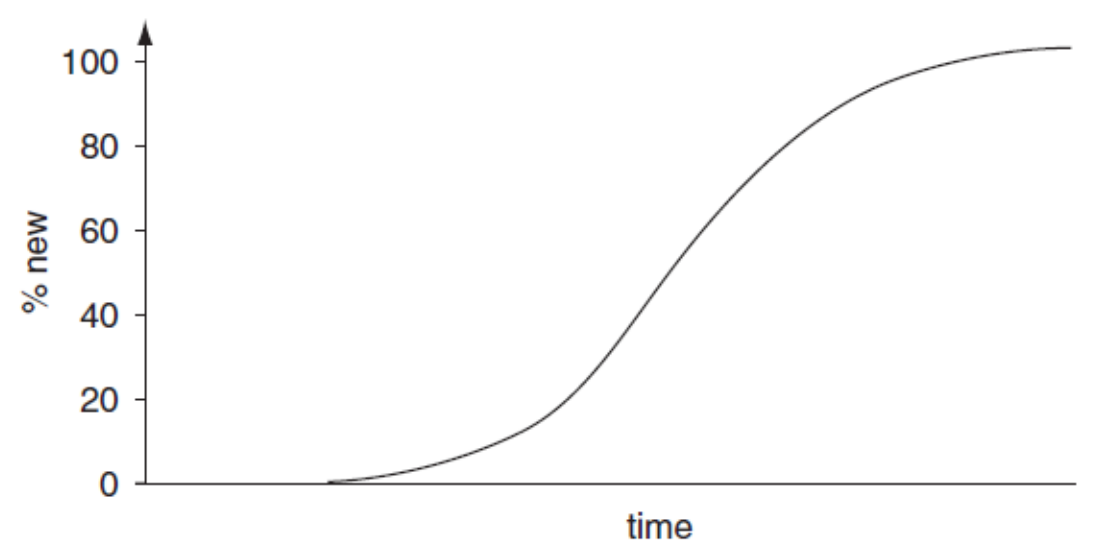

Gráfico 1.2 - Gráfico idealizador da curva- $S^{7}$

O efeito da mudança mostrado no gráfico (1.2) é gradual, ou seja, mudanças começam lentamente - com baixos percentuais de frequência, atingem um percentual alto de ocorrências e continuam em um ritmo lento. Segundo o autor, essa é a forma com que as mudanças se propagam na comunidade da fala, quando uma opção gramatical substitui a outra em processo de competição. O estudo da mudança sintática via competição de gramáticas tem mostrado que a gradação na frequência de uso de diferentes contextos superficiais reflete uma mesma mudança paramétrica - essa relação é denominada pelo autor de Hipótese da Taxa Constante.

A Hipótese da Taxa Constante revela que a gradação nas formas variantes no curso de uma mudança não é a mudança em si, ao contrário, é o reflexo de uma mudança na fixação de um mesmo parâmetro na gramática da língua.

Não há, porém, incompatibilidade entre a teoria internalista de mudança paramétrica, instantânea, individual, decorrente da aquisição da língua materna e a forma como a mudança paramétrica se propaga na comunidade de fala se considerarmos o seguinte ponto: enquanto a mudança paramétrica apresenta uma natureza cognitiva, fenômenos como curva-S, competição de gramáticas (diglossia) e efeito da taxa constante são apenas fenômenos de natureza extra-gramatical, determinados por fatores sociais, culturais, históricos, estilísticos, etc.

A conciliação entre as teorias está por trás de diversos estudos realizados nas últimas décadas, em particular, a linha de pesquisa iniciada por Kato \& Tarallo (1986, 2003), Tarallo

\footnotetext{
${ }^{7}$ Gráfico idealizador da curva-S de Kroch (DENISON (2003: 56), apud ROBERTS (2007:297)), sem numeração no original.
} 
\& Kato (1989), Roberts \& Kato (1993) que ficou conhecida como Sociolinguística Paramétrica.

Os autores sugerem a união da linguística paramétrica com a linguística quantitativa. Neste modelo, usam-se os resultados quantitativos como verificação das hipóteses propostas, extraídas da teoria gramatical escolhida.

\subsubsection{Um estudo de caso: o clássico exemplo do Parâmetro do Sujeito Nulo no PB}

Um número de propriedades diferencia sistematicamente línguas como o português, o italiano, o espanhol de línguas como o inglês e o francês, quanto à realização ou apagamento fonológico do sujeito pronominal. Esse contraste tem sido intensamente estudado na literatura corrente e recebeu a denominação de Parâmetro do Sujeito Nulo, o qual escolhemos como exemplo clássico de fenômeno que pode ser abordado dentro de um quadro gerativista e variacionista. Além disso, é relevante para os estudiosos que não só abordam aspectos da sintaxe comparativa, mas também tentam desvendar aspectos de mudança linguística e de aquisição da linguagem.

Já as gramáticas históricas e tradicionais mencionam, no estudo de línguas como o latim e grego, por exemplo, o fato de que as terminações pessoais dos verbos distinguindo pessoa e número tinham efeito na forma como o sujeito pronominal seria expresso, na medida em que consideravam redundante o seu uso diante das conjugações verbais "ricas morfologicamente”. Dentro do quadro teórico gerativista, Rizzi (1982) ficou conhecido pelo seu trabalho clássico, por estabelecer as propriedades que marcariam línguas de sujeito nulo de um lado, entre elas o italiano, e línguas de sujeito obrigatoriamente preenchido de outro, como o francês e o inglês. A partir desse trabalho, uma enorme literatura foi desenvolvida, abrangendo um enorme leque de línguas. Os estudos comparativos e históricos vieram revelar que a relação entre realização ou apagamento dos sujeitos referenciais e expletivos, e a flexão verbal era apenas um dos aspectos que precisavam ser considerados. Muitos outros fatores foram sendo considerados e trabalhados na tentativa de explicar esse ponto marcante de variação entre as línguas.

Assim, os pesquisadores acabam por descobrir que há línguas de tópico desprovidas de um sistema de flexão verbal de pessoa e número, como o chinês, que poderiam licenciar o sujeito pronominal nulo. Ou ainda línguas como o PB, em que esse parâmetro parece ser instável, uma vez que se observam diferenças entre o registro coloquial e culto. Recentemente, o PB tem sido considerado como língua de sujeito nulo parcial, em que o 
sujeito pronominal pode permanecer ou não expresso em condições restritas, determinadas tanto pelo contexto morfológico quanto o sintático.

Em particular, o PB tem-se apresentado como uma língua de grande interesse para os estudos de sintaxe diacrônica, uma vez que vem mostrando um declínio na ocorrência do sujeito nulo referencial definido, ao contrário do que revela o português europeu (PE) (cf. DUARTE 1993, 1995, 2003; DUARTE, KATO E BARBOSA, 2001). Para a autora, a elevação do nível de realização do sujeito pronominal estaria relacionada com a substituição do pronome pessoal tu pelo pronome de tratamento você e com a concorrência da expressão $a$ gente com o pronome nós, levando ao enfraquecimento da morfologia verbal. Os rearranjos no quadro do sistema dos pronomes pessoais ganham força nas primeiras décadas do século XX e levam a uma expressiva redução na flexão verbal, pois, tanto você, quanto a gente, coocorrem com as formas verbais de $3^{\mathrm{a}}$ pessoa do singular, ou seja, sem um morfema específico de pessoa e número.

Duarte (1993) demonstra que o nível de preenchimento do sujeito pronominal em PB, no seu corpus composto por peças teatrais, salta de 25\%, em 1918, para 46\%, em 1937; atingindo os níveis de 67\% e 74\% de sujeitos realizados, em 1975 e 1992, respectivamente. O gráfico1.3 expressa a progressiva redução no percentual de sujeitos nulos nas peças analisadas $^{8}$ :

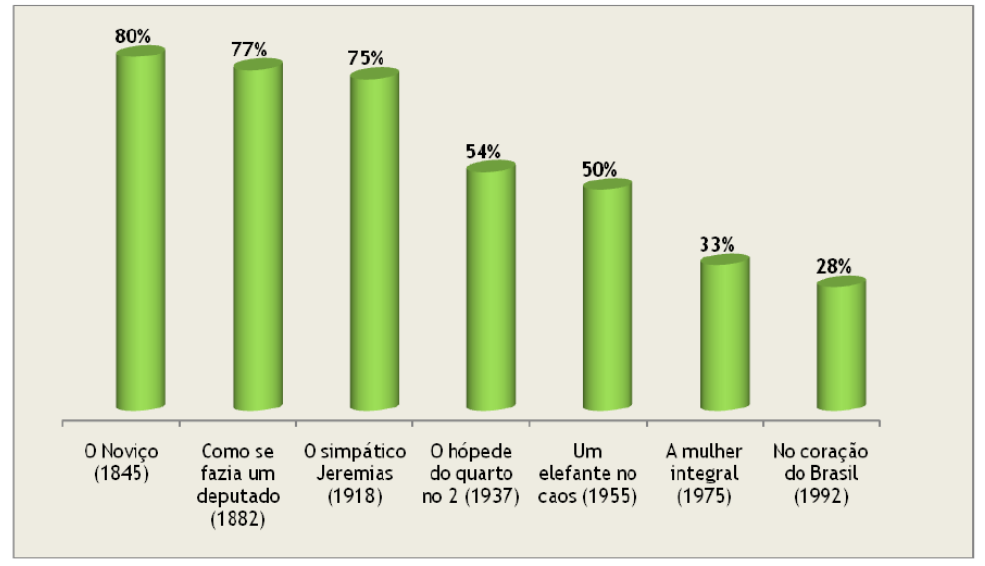

Gráfico 1.3: Sujeito nulo nas peças teatrais dos séc. XIX e XX

A autora identifica dois momentos em que houve uma redução significativa no percentual de sujeitos nulos: a primeira a partir da terceira década do século XX e a segunda no último quarto do mesmo século.

Assim, o paradigma flexional do verbo no PB teria deixado de ser funcionalmente "rico", provocando, então, a preferência pela expressão do sujeito, como vemos nas duas 
últimas colunas do gráfico 1.3, em que o percentual de sujeitos nulos é bastante baixo (33\% e $28 \%)$.

Nos estudos sobre o tema é possível ainda verificar que acontece um licenciamento seletivo do sujeito nulo no PB. Cyrino, Duarte e Kato (2000), para dar conta desse fato, propõem que a mudança que envolve categorias vazias se desenvolve condicionada por uma hierarquia de referencialidade, na qual a primeira e segunda pessoas, com o traço inerentemente [+hum], ocupam as posições mais altas na escala e o expletivo, isto é, a terceira pessoa, sem traços de pessoa, a posição mais baixa. Isso as leva a crer que, eventualmente, o PB poderia vir a desenvolver um expletivo lexical ao final da mudança.

Estudando o declínio dos sujeitos nulos, de um lado, e o desenvolvimento progressivo do objeto nulo, de outro, as autoras concluem que a referencialidade tem uma relevância altamente preditiva na pronominalização. A hierarquia de referencialidade prediz, parcialmente, o que ocorre com os dados, isto é, onde ainda podemos ter nulos sem restrição. Podemos dizer que o PB é pautado não pelo princípio "Evite Pronome", tal como formulado em Chosmky (1981), mas pelo princípio parcial "Evite pronomes referencialmente deficientes". Dessa forma, é possível afirmar que a sintaxe do PB vem mudando e que a variação exibida não é apenas efeito de uma mudança em curso, mas que ela pode ser explicada como propriedades de uma gramática estável caracterizável em termos de restrições semânticas de referencialidade e de propriedades morfossintáticas.

\section{Hierarquia Referencial}

\begin{tabular}{|c|c|c|c|}
\hline não-argumento & proposição & $\begin{array}{c} \pm \text { humano } \\
3 \mathrm{p} .\end{array}$ & $\begin{array}{l}\text { +humano } \\
2 \text { p. } 1 \text { p. }\end{array}$ \\
\hline
\end{tabular}

Em Kato e Duarte (2014), reforça-se a ideia de que, no PB, quanto mais referencial é o pronome pessoal, maior a expectativa de que seja expresso, retomando dessa forma a proposta da "hierarquia da referencialidade". No entanto, como as autoras observam, ainda retomando trabalhos anteriores, o PB apresenta uma outra propriedade interessante que é o fato de não ter gramaticalizado um pronome para desempenhar a função de sujeito expletivo (Øexpl), mas adotam uma estratégia de inversão locativa, como visto nos exemplos abaixo: 
(1) a. Øexpl chove muito nessas florestas.

b. Essas florestas chovem muito (redação de vestibular).

(Kato e Duarte $(2014: 7))^{10}$

Um outro resíduo de língua de sujeito nulo no PB é o nulo genérico (Øgen), que se tornou possível com o desaparecimento do se indefinido (cf. GALVES, 1987; NUNES, 1990). Observa-se, porém, que o nulo genérico entra em competição com os pronomes a gente ou você, nas quais se observa a não obediência ao princípio "Evite Pronome". Vejamos os exemplos por nós formulados abaixo com base na nossa intuição linguística:

(2) a. Øgen age-se com a razão e não com o coração.

b. Øgen age com a razão e não com o coração.

c. A gente age com a razão e não com o coração.

d. Você age com a razão e não com o coração.

Outro ponto importante é a emergência de estruturas com sujeitos deslocados à esquerda e à direita que são retomados por um pronome expresso dentro da sentença, como exemplificado em (3a-c). Essas estruturas não ocorrem em línguas de sujeito nulo, como o PE, o espanhol e o italiano, mas são altamente frequentes no francês, por exemplo, língua de sujeito pleno.

(3) a. O Pedro, ele não sabe o que diz.

b. Ele nunca sabe o que diz, o Pedro.

c. O Pedroi reconheceu que elei nunca sabe o que diz.

No entanto, ao mesmo tempo em que as sentenças acima mostrem indícios de sujeito pleno no PB, um pronome expresso não é possível em construções impessoais, como em (1a), ao contrário do que ocorre no francês. Isso leva a crer que, eventualmente, o PB poderia vir a desenvolver um expletivo lexical ao final da mudança.

Como Duarte e Kato (2014) concluem, a sintaxe do PB vem mudando e a variação exibida não é apenas efeito de uma mudança em curso, mas ela pode ser explicada como propriedades de uma gramática estável caracterizável em termos de restrições semânticas de referencialidade e de propriedades morfossintáticas.

\footnotetext{
${ }^{10}$ Kato e Duarte (2014:7), exemplo 16.
} 
Dessa forma, o presente capítulo apresentou os dois quadros teóricos em que se baseiam nossa análise: a teoria dos Princípios \& Parâmetros (CHOMSKY 1981, 1986) incluindo alguns refinamentos do Programa Minimalista (CHOMSKY 1995, 1998, 2000, 2001, 2004), e os pressupostos elaborados dentro da Sociolinguística Variacionista, também denominada Sociolinguística Laboviana (cf. WEINREICH, LABOV E HERZOG (WLH) (1968); LABOV (1972)), considerando ainda estudos posteriores que conciliaram a mudança paramétrica "internalista" da língua (ROBERTS (2007)) com fatores extragramaticais que determinam o percurso das formas linguísticas no tempo histórico (KROCH (1989, 1994, 2000)).

Trouxemos os conceitos básicos que levam ao conhecimento da Sociolinguística Laboviana, discutimos a teoria da variação no contexto da mudança linguística e apresentamos o estudo de Pereira (2007) como exemplo de aplicação da metodologia. Também apresentamos a investigação gerativa da linguagem humana, os principais pressupostos da Teoria dos P\&P e um pouco do quadro do Programa Minimalista. Baseandonos em Roberts (2007) mostramos um pouco sobre a variação e a mudança sintática, bem como a visão paramétrica da língua. Procuramos, contudo, associar a visão internalista da mudança e a pesquisa variacionista, discutindo aspectos da mudança paramétrica e fatores extralinguísticos que tornam possível o casamento dessas duas teorias. 


\section{PROPOSTAS DE ANÁliSES PARA UM ESTUDO DO DP POSSESSIVO NO PE E NO PB}

Como já mencionado na introdução, o principal objetivo desta dissertação é apresentar uma proposta de análise para a conhecida variação que caracteriza a gramática do português brasileiro (PB), a saber, presença vs. ausência de artigos definidos diante de possessivos prénominais. Neste capítulo vamos apresentar aspectos relevantes de alguns estudos recentes que trataram o fenômeno, tanto no português europeu (PE), quanto no português brasileiro (PB). Esse aspecto comparativo é necessário para caracterizar gramáticas distintas que hoje identificam as duas variedades do português, referente à combinação do artigo definido e possessivo pré-nominal, a saber: em diferentes contextos sintáticos, os sintagmas nominais possessivos exigem a realização do artigo definido no $\mathrm{PE}$, mas apresentam variação no português brasileiro (PB).

Assim, na seção 2.1, o objetivo é apresentar as hipóteses levantadas em Floripi (2008), empiricamente apoiadas num corpus histórico do português, do século XVI ao século XIX. Na seção 2.2, apresentamos uma breve notícia do estudo de Magalhães (2002). Na seção 2.5, apresentamos a abordagem de Castro (2006), com ênfase na sua perspectiva de uma diferença microparamétrica entre o PE e PB, de natureza morfofonológica, com base na hipótese de artigos definidos expletivos nulos e realizados lexicalmente, nos contextos possessivos. Por sua vez, Rinke (2010), na seção 2.4, inclui uma proposta bastante interessante, que se destaca das demais, no que se refere ao estatuto do artigo definido nos contextos possessivos. $\mathrm{O}$ estudo também é relevante por incluir um percurso histórico que se inicia na fase arcaica do português. O mesmo período é considerado por Costa (2002), como exposto na seção 2.5. No entanto, os dois estudos se complementam por apresentarem enfoques distintos em relação aos dados. Por fim, na seção 2.6. incluímos o estudo de Brito (2007), destacando, em particular, a sua proposta para o DP possessivo do PE, e a sua hipótese a respeito da natureza interna e externa dos possessivos dentro da estrutura DP. Ambos os pontos serão bastante relevantes para a análise que vamos propor no capítulo 3, para a estrutura do DP no PB, e para os aspectos gramaticais dos possessivos e artigos definidos. 


\subsection{O estudo de Floripi}

Um dos estudos que mais de perto dialoga com o tema da nossa dissertação é o de Floripi (2008). Na sua tese de doutoramento, a autora refaz um percurso da história do português, a partir do século XVI até o século XIX, verificando uma mudança gramatical nos padrões de aplicação do determinante com formas possessivas em posição pré-nominal, no interior do sintagma determinante (DP). ${ }^{11}$ Em particular, observa-se que no período denominado de Português Clássico (PC), o qual inclui os séculos XVI e XVII, dois sistemas gramaticais coocorriam na língua: um com a obrigatoriedade no uso do artigo definido diante do possessivo e outro em que o mesmo não era realizado ${ }^{12}$.

Tal variação, porém, se resolve pela obrigatoriedade da realização lexical do artigo nas estruturas do tipo DET+ POSS $+\mathrm{N}$, no português europeu moderno $(\mathrm{PE})$, fato este que a autora registra, com apoio na literatura recente, produzida por pesquisadores portugueses, entre eles, Castro (2006); Castro e Costa (2002); Miguel (2002a); Brito (2007). Vejamos o contraste entre as duas fases da língua nos exemplos abaixo: ${ }^{13}$

(1) a. O meu livro novo chegou Português Clássico
b. Meu livro novo chegou

(2) a. O meu livro novo chegou Português Europeu Moderno

b.* Meu livro novo chegou

O interesse pelo percurso histórico que vai do PC ao PE moderno leva a pesquisadora à escolha de um corpus composto de 23 textos de autores portugueses nascidos ao longo do período investigado, ortograficamente transcritos e morfologicamente etiquetados, os quais fazem parte do acervo documental pertencente ao Corpus Tycho Brahe ${ }^{14}$. Tomando como base uma abordagem quantitativa dos dados analisados, ela observa que é a partir do século XVII que o uso do artigo diante dos possessivos teve a frequência aumentada, o que lhe

\footnotetext{
${ }^{11}$ Adotaremos a sigla DP (Determiner Phrase) para nos referirmos ao sintagma determinante.

${ }^{12}$ Com a denominação Português Clássico a autora corrobora a hipótese de Galves (1996, 2001, 2004) e de Paixão de Sousa (2004), no sentido de ter havido um estágio gramatical intermediário entre o português antigo/arcaico (PA) e o PE.

${ }^{13}$ Floripi (2008:1), sem numeração no original.

${ }^{14}$ Corpus disponível no site: www.ime.usp.br/ tycho/corpus.
} 
permite formular a hipótese de que uma das gramáticas existentes no PC teria sido reanalisada, acarretando a generalização no emprego do artigo.

Adotando os pressupostos teóricos da Teoria dos Princípios e Parâmetros, em particular a vertente minimalista (CHOMSKY (2005)), e com base em autores como Kayne (1994), e Schoorlemmer (1998), Floripi propõe que os padrões de aplicação do artigo nos DPs possessivos expressam um processo de competição de gramáticas, nos termos de Kroch (1989, 1994, 1999, 2000). Segundo Floripi a substituição de uma gramática antiga pela nova não se propaga subitamente na comunidade, mas de forma gradual, sendo evidenciada pela variação de resultados obtidos no decorrer do tempo, elucidando que as duas gramáticas ainda podiam coocorrer na língua. ${ }^{15}$

A atenção da autora gira ainda em torno de Longobardi (1994), por sua hipótese universal do DP, segundo a qual todas as línguas, independentemente do fato de terem ou não artigos, realizados ou nulos fonologicamente, evidenciam que todo sintagma nominal em posição de argumento realiza-se obrigatoriamente com uma estrutura DP. ${ }^{16}$ Como Floripi comenta:

[...] a Hipótese de DP contribuiu para uma análise sintática e semântica dos constituintes nominais ao abrir caminho para a realização de diversas investigações sobre a tipologia linguística do uso de determinantes nos sintagmas possessivos, sobre a relação morfossintática entre os clíticos e os determinantes e sobre o status da expressão nominal, entre outras tantas análises.

(Floripi, 2008: 31)

Na verdade, as hipóteses a respeito de como está arquitetada a estrutura interna do DP têm ganho uma grande espaço na pesquisa recente. Alguns autores propõem que a estrutura do DP reflete a estrutura sentencial, ou seja, possui núcleos funcionais que podem ser relacionados aos que são propostos para as sentenças (cf. entre outros, SZABOLCSI 1983, 1987). Da mesma forma, outros pesquisadores aumentaram o leque das categorias funcionais introduzidas no interior da frase nominal, entre elas, Num P (cf. entre outros, RITTER 1987, 1991) e PossP (cf. entre outros SCHOORLEMMER (1998) e RINKE (2010)).

\footnotetext{
${ }^{15}$ A autora revisa igualmente as principais propostas de mudança dentro da Teoria dos Princípios e Parâmetros de Lightfoot (1979, 1991, 1998), a noção de definitude de Lyons (1999), e a abordagem da gramaticalização do artigo definido, a partir dos demonstrativos, nos moldes de Roberts \& Rousseau (2003).

${ }^{16}$ Como se sabe, Abney (1987) foi o primeiro a propor que determinantes (artigos e demonstrativos) fossem definidos como categorias funcionais nucleares que selecionam um elemento lexical - o sintagma nominal, criando assim, o que passou a ser denominado de Sintagma Determinante (Determiner Phrase- DP).
} 


\subsubsection{Os dados}

Na primeira etapa de seu trabalho, os dados foram quantificados a partir de três critérios:

(i) presença ou ausência do artigo;

(ii) posição na oração do sintagma contendo o possessivo (se em posição inicial de frase ou se localizado dentro de uma oração) e;

(iii) presença ou ausência de uma preposição que antecede o DP contendo o possessivo.

Provenientes desses critérios, dez tipos de contextos foram delineados e quantificados, na tentativa de visualizar os ambientes de variação do determinante em DPs possessivos.

Com relação à posição do DP possessivo em posição inicial absoluta foram buscados os seguintes contextos:

- Sintagma possessivo em posição inicial absoluta na oração (rotulado como 0 - poss):

"Seu corpo foi enterrado o mais solenemente que pôde ser, com grande dor, e sentimento de todos, de que era muito amado, como era razão o fosse um Rei." (Couto, 1542).

(Floripi 2008: 125)

- Sintagma possessivo em posição inicial absoluta na oração + determinante (rotulado como 0

$-\mathrm{D}$ - poss);

“O seu pintar é trapos, maçonerias, verduras de campos, sombras de árvores, e rios e pontes, a que chamam paisagens, e muitas feguras para cá e muitas para acolá.” (Holanda, 1517).

(Floripi 2008: 126)

- Sintagma possessivo em posição inicial absoluta na oração + preposição (rotulado como 0 $\mathrm{P}$ - poss);

"De sua dificultosa conquista, a redução à Fé, empresa digna do grande coração de VIEIRA, e uma de suas maiores façanhas, demos já em separada obra completa relação.” (Barros, 1675).

(Floripi 2008: 126) 
- Sintagma possessivo em posição inicial absoluta na oração antecedido por uma preposição + determinante (rotulado como $0-\mathrm{P}$ - D- poss);

"Contra o nosso parecer, nunca achamos dúvida bastante, contra o dos outros sim." (Aires, 1705).

(Floripi 2008: 126)

- Sintagma possessivo em posição inicial absoluta na oração antecedido pela contração de uma preposição com um determinante (rotulado como 0 - PD - poss);

“ No nosso Evangelho diz o mesmo Senhor: Tunc videbunt: então verão: E aquelle então é agora: aquelle tunc é nunc: Tunc videbunt, et nunc est.”(Sermões, Vieira, 1608).

(Floripi 2008: 126)

E com relação à posição do DP possessivo em posição interna à oração foram buscados os seguintes contextos:

- Sintagma possessivo interno a uma oração e precedido por um determinante (rotulado como $\mathrm{D}$ - poss);

"São Paulo descrevendo este mundo, para nos desaffeiçoar de suas vaidades, diz que é como um theatro, em que as figuras cada uma entra a representar o seu papel, e passa: Præterit enim figura hujus mundi." (Sermões, Vieira, 1608).

(Floripi 2008: 127).

- Sintagma possessivo interno a uma oração e precedido por uma preposição (rotulado como (P-poss);

“Nem cuideis, que vos conheço, quem quer que sois, nem que ponho o dedo em vossas couzas em particular: o meu zelo bate só no commum." (Manuel Antônio da Costa, 1601).

(Floripi 2008: 127)

- Sintagma possessivo interno a uma oração e precedido por uma preposição + determinante (rotulado como $\mathrm{P}$ - D -poss);

"Porém, quanto a mi, o que da tenção dêstes autores convém mais com o nosso modo de fala, sal quer dizer graça, que é o contrário da frieza e sensaboria. (Lobo, 1579).

(Floripi 2008: 127) 
- Sintagma possessivo interno a uma oração e precedido pela contração de uma preposição com um determinante (rotulado como PD - poss) e;

“No mês de Maio dos anos do Senhor de mil e quinhentos e catorze, reinando em Portugal elRei Dom Manuel, único deste nome, e presidindo na Igreja de Deus o Papa Leão X, pariu Maria Correa um filho, que bautizaram na sua igreja e freguesia e chamaram Bertolameu. (Souza, 1556).

(Floripi 2008: 127)

- Sintagma possessivo interno a uma oração precedido por outro elemento qualquer que não um determinante ou uma preposição (rotulado como X-poss)

"Mas como não é Vossa Mercê que me informa dessas circunstâncias, é fôrça que minha amizade penda mais para o pesar que para o gôsto. (Brochado, 1651).

(Floripi 2008: 127).

Como segunda etapa, 18 fatores ${ }^{17}$ foram considerados para a classificação de cada um dos DPs possessivos encontrados:

1) A posição do possessivo na sentença;

2) $\mathrm{O}$ elemento anterior ao pronome possessivo;

3) A presença ou ausência do determinante;

4) Os tipos de preposição encontrados;

5) A ocorrência ou não da contração da preposição com o determinante;

6) A definitude do determinante;

7) $\mathrm{O}$ gênero do pronome possessivo;

8) O número do pronome possessivo;

9) A pessoa do pronome possessivo;

10) O tipo de possessivo encontrado;

11) O elemento posterior ao pronome possessivo;

12) O tipo de núcleo do sintagma nominal;

13) O tamanho do sintagma nominal possessivo;

14) Os traços semânticos do núcleo do DP possessivo;

15) A função sintática do sintagma nominal possessivo;

\footnotetext{
${ }^{17}$ A autora considera o item (3) como fator. Nós o consideraremos como a metodologia quantitativa sugere: variável dependente. Cf. Caps. 1 e 4.
} 
16) $O$ gênero textual em que o referido dado se encontrava;

17) O período em que o referido dado se encontrava;

18) $\mathrm{O}$ texto em que o referido dado se encontrava.

\subsubsection{Resultados quantitativos}

Após realizada a classificação dos dados, o próximo passo na pesquisa foi o de dar início ao processo de quantificação e análise. No gráfico 2.1, temos o resumo de sua detalhada análise. Nele podemos visualizar de forma clara o percurso percentual da ocorrência dos determinantes nos DPs possessivos ao longo do período histórico considerado.

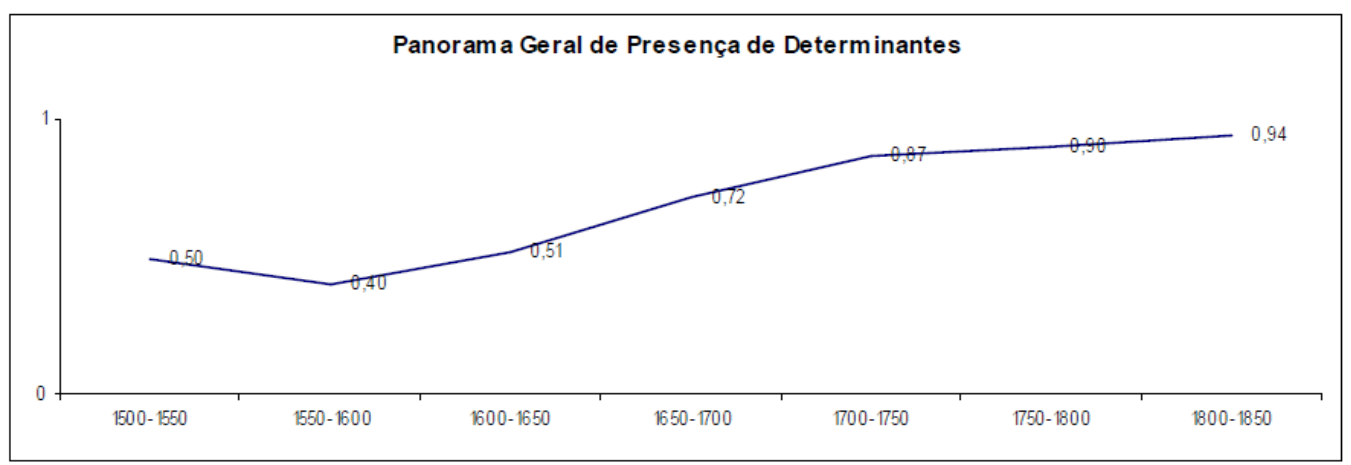

Gráfico 2.1 - Percentual de ocorrências do determinante nos DPs possessivos. ${ }^{18}$

Por meio desse gráfico, fica evidenciada uma variação no uso do determinante diante do possessivo no PC, e uma mudança no sentido da sua sistematicidade nos textos dos escritores portugueses, no decorrer dos séculos XVI ao XIX. Na avaliação de Floripi, o gráfico representa, nitidamente, a tendência para uma mudança na aplicação do artigo no PC. Assim, no início do século XVI, até meados do século XVII, o percentual de artigos girava em torno de 50\%, o que revela uma grande oscilação. Em seguida, já na segunda metade do século XVII, observa-se um crescimento acentuado de $50 \%$ a $70 \%$.

Ao olhar mais de perto para os contextos escolhidos, Floripi afirma que, em seus resultados, o fator sintático não exerce um grande peso para o licenciamento ou não do artigo nos DPs possessivos, de modo que apenas a presença ou não da preposição pode ser considerada significativa. Ela observa que a maioria dos sintagmas preposicionados, embora

\footnotetext{
${ }^{18}$ Floripi (2008:138), gráfico 2.
} 
possam ocorrer como complementos, tem a sua maior produtividade como adjuntos. Assim, embora haja uma preferência quase absoluta para o uso do DP possessivo em posição interna da sentença, as posições sintáticas distintas, entre elas, sujeito e objeto direto não favoreceram o aumento percentual no uso dos artigos.

A autora considera ainda os resultados obtidos com relação a outros fatores, como número, gênero, pessoa e tamanho do DP possessivo, os tipos de núcleos do Sintagma Nominal, entre eles, nomes comuns, nomes próprios e nomes relacionais.

\subsubsection{Gramáticas em competição no $P C$ e as mudanças que levam às gramáticas do PE}

Pode-se afirmar que Floripi (2008), sob uma perspectiva diacrônica, mostra que o fator fundamental para se entender a implementação da mudança na realização do artigo é a presença ou não de uma preposição junto ao DP possessivo, corroborando estudos anteriores, como o de Silva (1982) e Magalhães (2002), nos quais já havia sido notado que os contextos preposicionados diferem dos contextos não preposicionados. Logo, o uso da preposição junto aos DPs possessivos é realmente um fator atuante para a mudança presenciada ${ }^{19}$.

A hipótese da autora para o fenômeno da variação no uso do determinante, quando introduzido por preposições, é a de que a preposição poderia estar sendo analisada como um núcleo funcional, não lexical, o que tornaria permissível a contração da preposição com os traços do determinante. Tal contração, porém, nem sempre aparece expressa em uma realização morfologicamente visível. Assim, no PC, as preposições seriam capazes de licenciar os traços de definitude em $\mathrm{D}$, por projeção estendida ${ }^{20}$, permitindo que o artigo fosse omitido em alguns casos. Isso explicaria o fato de que muitos DPs preposicionados não realizavam o artigo.

Um outro ponto que merece destaque diz respeito aos sintagmas possessivos que têm como núcleos nomes relacionais, ou seja, nome que se referem a relações de parentesco e

\footnotetext{
${ }^{19}$ De acordo com os seus dados, o número de ocorrências do uso do determinante sem a preposição sempre foi relativamente grande, desde o século XVI, sofrendo uma variação no decorrer dos séculos até alcançar um percentual em torno dos $90 \%$ a partir de meados de 1650 .

${ }^{20}$ Lembramos que a noção de projeção estendida (extend projection) foi originalmente proposta por Grimshaw (1991), segundo a qual a estrutura de uma sentença é a projeção estendida de VP, dominada por duas categorias funcionais: IP e CP. O conjunto dessas duas categorias constitui a projeção estendida. Da mesma forma, Grimshaw (2006) propõe que o DP é uma categoria funcional para o núcleo N, assim como o IP é para o núcleo V. Na proposta de Floripi (2008), o PP também se colocaria como uma projeção estendida do núcleo N.
} 
amizade- pai, mãe, filho, etc.- Como a autora enfatiza, embora tais casos não tenham sido numerosos, eles eram claramente inibidores do uso do artigo, uma vez que, desde 1500 até1700 havia pouquíssimas ocorrências de artigo que variavam de $0 \%$ a cerca de $30 \%$. A partir de 1700, porém, foi possível encontrar autores já com indices maiores na realização dos artigos com nomes de parentesco, e após 1750, os textos investigados revelam casos de $68 \%$, chegando a 97\% em Almeida Garret, nascido em 1799. Portanto, segundo Floripi, tais contextos são também importantes para refletir o percurso da mudança de natureza gramatical no PE.

Como acima mencionamos, ao reunir os resultados que englobam tanto DPs possessivos sem preposição, quanto DPs possessivos preposicionados, a autora observa que, até os anos de 1650-1700, há variação no uso do artigo, mas sem evidência de um contexto estabelecido de mudança, o que permite afirmar a existência de dois panoramas de mudança, remetendo a distintos sistemas possessivos. Com base na tipologia de Schoorlemmer (1998), Floripi assume duas gramáticas para a fase clássica do português, uma do tipo do francês moderno, que não permite a coocorrência do artigo e possessivo (* le mon livre) e outra do tipo do italiano moderno que tem artigo nos DPs possessivos (il mio libro), como mostram, respectivamente, as figuras (2.1) e (2.2):

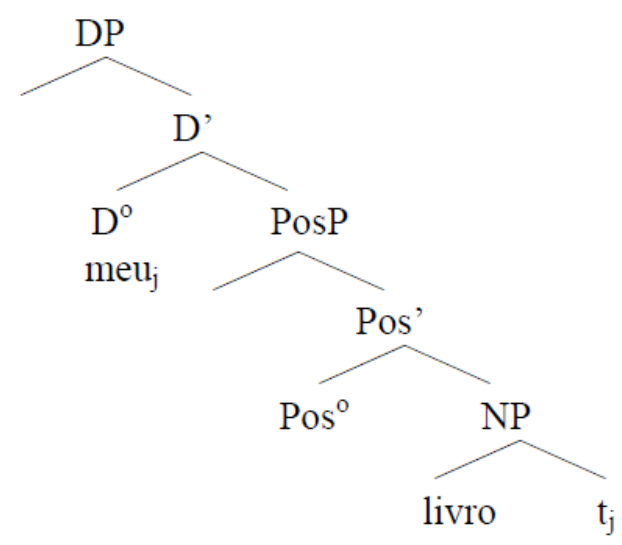

Figura 2.1: representação arbórea da gramática do tipo francês ${ }^{21}$

\footnotetext{
${ }^{21}$ Floripi (2008:190), sem numeração no original.
} 
Gramática do Tipo Italiano

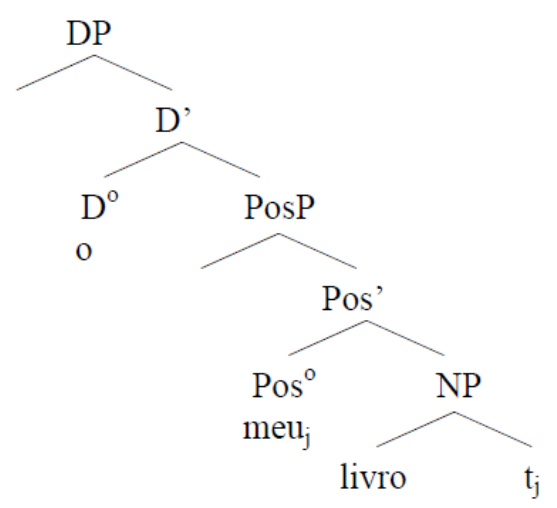

Figura 2.2: representação arbórea da gramática do tipo italiano ${ }^{22}$

A autora assume ainda a proposta de inserir nessas estruturas uma projeção Agr (Agreement) ${ }^{23}$, expressiva da concordância entre os elementos relacionados pela posse. Além disso, o fato de se ter núcleos distintos para o artigo e o pronome favorece a hipótese de que a preposição e o artigo podem ser concatenados dada a sua adjacência, sem que isso venha a afetar o pronome possessivo que se encontra em uma posição mais baixa em (AgrP). As derivações abaixo podem exemplificar melhor esses traços:

Gramática - tipo Francês

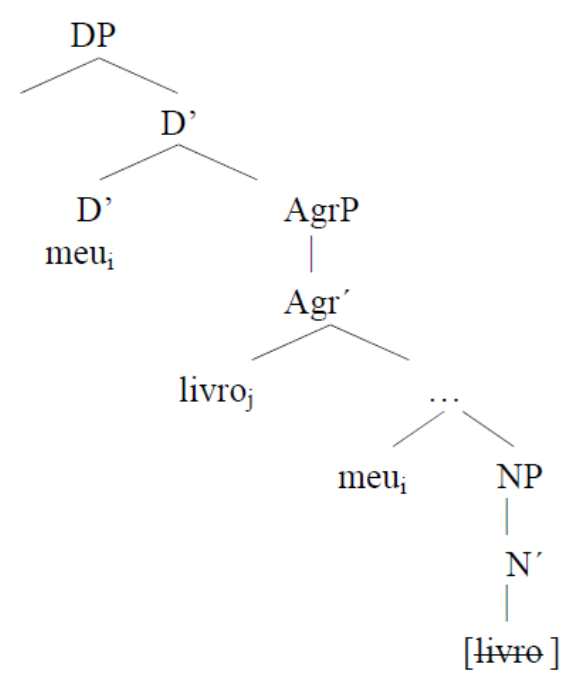

Figura 2.3: representação arbórea da gramática do tipo francês com $\mathrm{AgrP}^{24}$

\footnotetext{
${ }^{22}$ Floripi (2008:190), sem numeração no original.

${ }^{23}$ Em português, Concordância.

${ }^{24}$ Floripi (2008:210), exemplo 191.
} 


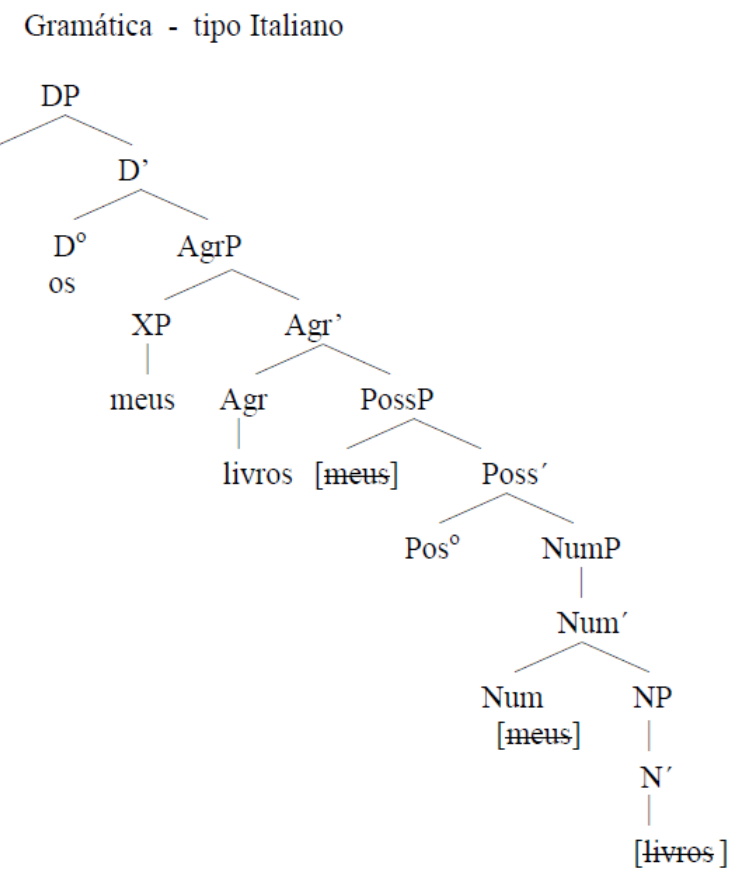

Figura 2.4: representação arbórea da gramática do tipo italiano com AgrP. ${ }^{25}$

Como dissemos acima, uma das gramáticas do PC (Gramática 2- G2) seria identificada como a do italiano: o uso do artigo antes do possessivo não está em variação. $\mathrm{O}$ possessivo permanece no núcleo de PossP, deixando livre a posição D para que o artigo seja inserido, checando o traço de definitude. Entretanto, como dito acima, observa-se que, na fase clássica, há uma segunda gramática do tipo do francês (Gramática 1- G1), na qual o possessivo ocupa a posição D e não coocorre com o artigo. Nesta gramática, o pronome possessivo detém os traços [+possessivo], [+definido], enquanto na anterior o possessivo tem apenas o traço [+possessivo]. O quadro abaixo evidencia as duas gramáticas do PC:

\begin{tabular}{|c|c|}
\hline $\begin{array}{l}\text { Gramática } 1 \text { - tipo Francês } \\
\text { [D meu }] \\
\text { [+definido, +possessivo }]\end{array}$ & $\begin{array}{l}\text { Gramática } 2 \text { - tipo Italiano } \\
{\left[\begin{array}{ll}\text { D } & \text { o }] \quad[\text { Agrp } \text { meu }] \\
{[+ \text { definido }] \quad[+ \text { possessivo }]}\end{array}\right.}\end{array}$ \\
\hline & $\begin{array}{l}\mathrm{P}+\mathrm{D}=\text { de meu }- \text { sem } \\
\text { morfologicamente visível } \\
\mathrm{P}+\mathrm{D}=\text { do meu }- \text { com } \\
\text { morfologicamente visível }\end{array}$ \\
\hline
\end{tabular}

Quadro 2.1 - Contextos de variação no início do século XVI no português.

\footnotetext{
${ }^{25}$ Floripi (2008:210), exemplo191.
} 
A competição entre as gramáticas no século XVI, exposta no quadro 1, resulta em que uma delas sai vencedora (tipo italiano), banindo a outra (tipo francês). Segundo a autora, o período de competição entre duas gramáticas distintas teria se iniciado em momento anterior ao século XVI, e tal competição teria feito com que a gramática do tipo francês fosse enfraquecida ao longo do tempo, e passasse a ser menos recorrente. Isso teria sido evidenciado pelos resultados com DPs em contextos sem preposição.

Na fase moderna do PE, a gramática do tipo francês desaparece definitivamente, não havendo mais possibilidade, em nenhum dialeto, de um uso do possessivo sem o artigo. No caso da gramática do tipo italiano, porém, seguindo Castro (2006), Floripi assume um segundo momento de mudança, no qual ocorre uma reanálise, descrita nos seguintes termos: o pronome possessivo passa a comportar-se como um elemento nuclear (X), e não mais como uma projeção máxima (XP), ocupando agora a posição D, juntamente com o artigo definido. ${ }^{27}$ Como se disse, tal gramática do possessivo pré-nominal corresponde à gramática padrão do PE moderno, diferenciando-o do italiano. ${ }^{28}$ As duas gramáticas do PE, a conservadora (dialetal) e a padrão estão no quadro 2.2:

\begin{tabular}{|c|c|c|}
\hline & Português Clássico & Português Europeu \\
\hline Gramática 1 & $\begin{array}{l}\text { [D } \text { meu }] \\
{[+ \text { definido, }+ \text { possessivo }]}\end{array}$ & \\
\hline Gramática 2 & $\begin{array}{lc}{\left[\begin{array}{ll}\mathrm{D} & \mathrm{O}\end{array}\right]} & {[\text { AgrP meu }]} \\
{[+ \text { definido }]} & {[+ \text { possessivo }]}\end{array}$ & 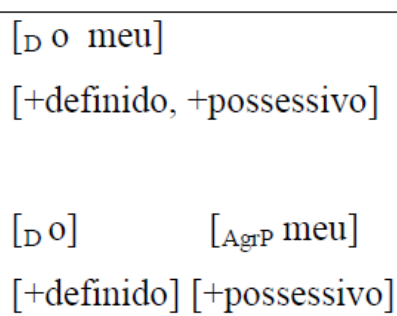 \\
\hline
\end{tabular}

Quadro 2.2 - Gramáticas do português clássico e do português europeu ${ }^{29}$

\footnotetext{
${ }^{26}$ Floripi (2008:212), quadro 16.

${ }^{27}$ Veremos esse ponto com maiores detalhes na seção 2.5.

${ }^{28} \mathrm{O}$ comportamento sintático/semântico dos possessivos pré-nominais no PE, levando em conta as diferenças dialetais tem ainda inspirado outras análises. Miguel (2002a), por exemplo, afirma que há evidências para se postular gramáticas em competição no PE para os possessivos pré-nominais. Há uma variedade dialetal, mais conservadora, na qual os possessivos podem coocorrer com uma artigo indefinido (um meu amigo...), caracterizando -se categoricamente como projeção máxima (XP). Uma outra gramática inovadora (padrão) caracteriza-se por ter o possessivo pré-nominal condicionado pela definitude do DP (o meu amigo). Nesta gramática os possessivos estariam apresentando uma reanálise, uma vez que tem um comportamento simultâneo de núcleo (X) e projeção máxima (XP). Por fim, uma $3^{\text {a }}$ gramática dialetal, na qual os possessivos se comportam como clíticos em D e estão associados aos artigos definidos (o me livro).

${ }^{29}$ Floripi (2008: 217), sem numeração no original.
} 
No entanto, embora assumindo com Castro (2006) que o possessivo pré-nominal no PE seja um núcleo gerado em D na variedade padrão do PE, juntamente com o artigo, Floripi rejeita a hipótese de que o artigo diante do possessivo comporte-se como um mero expletivo, sem conteúdo semântico ${ }^{30}$. Ou seja, para Floripi o processo de reanálise estrutural em que os traços dissociados de [+definitude, +posse] são realizados no mesmo núcleo $\mathrm{D}$, mostraria que o possessivo retém o traço de posse e o artigo o traço de definitude. Uma vez que ambos podem ser tratados como a realização morfológica de traços abstratos, não é necessário postular um artigo expletivo para ocupar o núcleo do DP, principalmente por duas razões. Primeiramente, por não estar muito claro por que, uma vez que o possessivo ocupa o núcleo do DP, o artigo expletivo tenha se tornado obrigatório para ocupar a mesma posição funcional. Em segundo lugar, por tal hipótese não deixar claro ou devidamente entendida a microvariação entre a obrigatoriedade fonológica da realização do artigo no PE, em oposição à sua variedade no PB. Por que a obrigatoriedade apenas em uma das variedades do português? ${ }^{31}$

Concluindo, podemos dizer que, para Floripi, a explicação para a mudança no uso do artigo em DPs possessivos, no percurso que leva da fase clássica para a fase moderna do PE é resultante de uma reanálise que faz com que o traço de definitude, associado ao traço de possessividade em $\mathrm{D}$, passe a ser morfologicamente realizado, respectivamente, por meio de um artigo e de um possessivo. Ou seja, depois da reanálise, a presença vs. ausência do artigo definido não está mais correlacionada a uma posição diferente do possessivo, nem a uma projeção categorial distinta como X ou XP. Nos dois casos, o possessivo é um núcleo em D.

\subsubsection{Proposta para o PB}

Apesar de o PB estar fora do escopo de sua tese, Floripi remete, por diversas ocasiões, a autores que discorreram sobre a variação no uso do determinante com DPs possessivos, entre eles, Silva (1982), Neves (1993) e Silva \& Callou (1996). Os dois últimos abordam dados de fala. A autora lembra ainda os vários estudos que trataram da perda do seu em favor da forma perifrástica dele. ${ }^{32}$

Em particular, Floripi retoma Costa \& Figueiredo Silva (2006) em um aspecto muito

\footnotetext{
${ }^{30}$ Discutiremos a proposta de Castro (2006) com maiores detalhes na seção 2.3.

${ }^{31}$ Lembrando que para Schoorlemmer (1998), a diferença fundamental entre as línguas deve-se à uma opção paramétrica no licenciamento do traço de definitude no DP: em PossP (para línguas como o Italiano) ou em D (para línguas como o francês).

${ }^{32}$ Cf. Cerqueira (1996)
} 
importante: o da concordância de número. Como se sabe, no PE há concordância sistemática de número entre artigo, possessivo e núcleo nominal no interior do DP. No PB, porém, segundo os autores, há dois dialetos, a saber, PB1 e PB2, que diferem na organização de um padrão de concordância. ${ }^{33}$ Assim, enquanto o primeiro se alinha ao padrão do PE (3a), o segundo apresenta variação. O que interessa salientar é que os pronomes possessivos, ao contrário dos adjetivos, podem ser os únicos que apresentam a expressão morfológica de número (3d). Além disso, não se pode ter marca de plural no artigo, sem a concordância com o possessivo $(3 \mathrm{c})^{34}$.
(3) a. Os meus livros (PE, PB1)
b. Os meus livro
c. *Os meu livro
d. O meus livro
(PB2)

Seguindo pressupostos da Morfologia Distribuída, os autores assumem que um morfema pode se realizar de duas formas: como morfema único (singleton), ou como morfema dissociado. A distinção entre o PE e PB decorre dessa dicotomia. Enquanto o PE revela um morfema de plural dissociado, pois, todos os elementos são capazes de carregar as marcas de plural, o PB apresenta um morfema único, sendo este marcado em D, ou no pronome possessivo, ou seja, no elemento semanticamente mais saliente.

Floripi evidencia ainda que, na presença da preposição, antes do artigo definido, os falantes aceitam sem dificuldades a expressão de número apenas no possessivo (4e): Vejamos alguns de seus exemplos:

(4) a. * Em os meus meninos ninguém bate

b. Nos meus meninos ninguém bate

c. Nos meus menino ninguém bate

d. ? Nos meu menino ninguém bate

e. No meus menino ninguém bate ${ }^{35}$

\footnotetext{
${ }^{33}$ Floripi não assume que a variação presença vs, ausência do artigo no PB reflita uma gramática conservadora, ou nos moldes do PC.

${ }^{34}$ Adaptamos a apresentação dos exemplos mencionados em Costa \& Figueiredo Silva (2006).

${ }^{35}$ Floripi (2008:230), exemplos 201 a-e .
} 
Floripi assume a proposta de Costa \& Figueiredo Silva para uma das gramáticas do PB (PB1), propondo que, nesta variedade, o possessivo se encontra em D e por isso recebe a marca de plural, em adjunção ao artigo. No entanto, como a autora reconhece, a hipótese do possessivo em D parece não ser possível para o BP2, uma vez que seria difícil justificar por que o artigo não pode apresentar a marca de plural, uma vez que está em $\mathrm{D}$, em adjunção ao possessivo. Dessa forma, ela afirma que a hipótese de que, no PB dialectal (PB2), os possessivos e os artigos ocupam posições sintáticas distintas parece mais coerente.

No Capítulo 3 retomamos alguns pontos da proposta de Floripi.

\subsection{Novos dados do Corpus Tycho Brahe: o estudo de Magalhães 2002}

Diacronicamente anterior ao estudo de Floripi (2008), o estudo de Magalhães (2002) apresenta uma hipótese para o artigo definido, dentro de uma perspectiva diacrônica, procurando mostrar a evolução do uso do artigo diante de pronomes possessivos e dos nomes próprios em um conjunto de 12 textos portugueses do período clássico do português (PC), igualmente disponibilizados no Corpus Tycho Brahe.

Seguindo os padrões de Longobardi (1994) e Schoorlemmer (1998), Magalhães explica os casos nos quais o possessivo, precedido pela preposição, podia dispensar o artigo. Para ela, assim como assumido por Castro (2006), o artigo é um expletivo e sua presença seria determinada pelo componente fonológico do traço de definitude que se realiza em D. A autora assume a hipótese de competição de gramáticas, tal como Schoorlemmer (1998): numa das gramáticas, o núcleo da categoria PossP tem um traço de definitude variável e movimento do possessivo para $\mathrm{D}$, neste caso, ocasionando a ausência do artigo diante do possessivo. Na outra gramática, o núcleo PossP não tem o traço de definitude variável, de modo que o possessivo não se move para $\mathrm{D}$ e o artigo pode co-ocorrer livremente com o possessivo.

Quando a autora compara seus contextos, ela conclui que existiram dois momentos na história do uso do artigo diante do possessivo em PE:

(i) no contexto dos DPs possessivos não preposicionados, a variação ainda ocorria no século XVI, vindo a desaparecer no século XVIII; e

(ii) para os DPs possessivos introduzidos por preposições, a variação tem início em meados de século XVII, perdurando ainda no século XIX. 
Entretanto, Magalhães não se detém no processo e mecanismos de mudança ocorrida no PC e no PE, ou seja, não aponta para os elementos e mecanismos que acarretaram a mudança gramatical desta língua.

\subsection{Castro (2006) e a hipótese do expletivo nulo}

Em Castro (2006), encontramos igualmente uma análise para o contraste observado entre o PE e PB no que diz respeito à presença do artigo diante do possessivo pré-nominal, em posição de argumento: o PE apresenta uma realização foneticamente obrigatória do artigo, enquanto no PB há uma realização variável. Como ela observa, o fenômeno também é interessante em termos históricos, uma vez que tal variação foi encontrada na documentação desde a fase arcaica do português. Castro parte da seguinte questão: o contraste observado entre o PE e o PB teria como causa o sistema dos possessivos ou o sistema dos determinantes? Para respondê-la, a primeira tarefa realizada consistiu em vasculhar a literatura relevante a respeito dos possessivos.

\subsubsection{Parametrização com base em diferentes línguas: o sistema possessivo}

A autora concentra-se nas propostas de Lyons (1985), Giorgio \& Longobardi (1991) e Schoorlemmer (1998), as quais têm em comum uma abordagem tipológica, com base em propriedades gramaticais dos possessivos, incluindo o seu comportamento sintático (distribucional), ora atuando como adjetivos, ora como determinantes. Nessa perspectiva, as línguas se dividem em dois grupos: línguas que impedem a presença do artigo diante do possessivo, como o espanhol e o francês, têm um possessivo determinante. Línguas que obrigam a presença do artigo têm um possessivo adjetival, como o italiano, o catalão e o PE.

Uma análise possível baseada nessa tipologia assume o possessivo determinante como ocupante da posição D, não havendo, pois, a necessidade de um artigo. Por seu lado, a natureza adjetival do possessivo determina que o artigo possa ser, ou não, o ocupante da posição D. No entanto, Castro rejeita tanto o Parâmetro Possessivo, dentro da Gramática Universal (GU), proposto por Lyons (1985) e Giorgi \& Longobardi (1991), quanto a divisão entre línguas do Tipo 1 e línguas do Tipo 2, como proposto em Schoorlemmer (1998). ${ }^{36}$ Com

\footnotetext{
36 "The Possessive Parameter" foi formulado nos seguintes termos: "Possessive elements are syntactically specifed to be realised on the surface either as Adjectives (as in Italian), or as Determiners (as in English or French).” (GIORGI \& LONGOBARDI (1991); apud CASTRO (2006:176)).
} 
isso, ela se recusa a assumir que a variação paramétrica entre o PE e o PB seja resultante do contraste categorial adjetivo vs. determinante do possessivo pré-nominal. Em outras palavras, a autora questiona a afirmação de que o PE e o PB deveriam enquadrar-se tipologicamente como línguas de possessivos adjetivais, ao contrário das línguas com possessivos determinantes, uma vez que vários problemas descritivos se apresentariam, entre eles. ${ }^{37}$

(i) No PB, os possessivos pré-nominais podem ocorrer sem o artigo definido, sem restrição contextual. Assim, o PB teria possessivos determinantes ao lado de possessivos adjetivais;

(ii) Os possessivos focalizados em sintagmas nominais definidos não podem ser pósnominais, ao contrário do que acontece em catalão e italiano.

(iii) Os possessivos pré-nominais não podem ocorrer em sintagmas nominais indefinidos, ao contrário do que acontece em catalão e italiano.

Ao recusar a hipótese de que as diferenças entre o PE e PB estariam enraizadas no estatuto adjetival vs. determinante dos possessivos, a autora passa a considerar a natureza pronominal dos possessivos. Disso resulta a convicção de que um conjunto de propriedades sintáticas, morfológicas e semânticas sustentam a oposição deficiente/forte, tal como proposto em Cardinaletti \& Starke (1999) e Cardinaletti (1998), inicialmente com base no sistema dos pronomes pessoais, mas, posteriormente, abrangendo o sistema dos possessivos, num conjunto de línguas românicas e germânicas

Segundo os autores, também no sistema dos possessivos há uma divisão tripartida entre pronomes fortes, fracos e clíticos, ou seja, os pronomes deficientes podem ser subdivididos em fracos ou clíticos. Assim, os pronomes fracos diferenciam-se sintaticamente dos clíticos por serem projeções máximas (XP), igualando-se, neste aspecto, aos pronomes fortes, enquanto os clíticos são núcleos (X). Isso significa que, no interior do DP, os possessivos clíticos se adjungem a $\mathrm{D}$, e os pronomes fracos são gerados numa posição prénominal de especificador, abaixo de D. Os pronomes possessivos fortes, por sua vez, embora XPs, são gerados na posição pós-nominal no interior do DP.

\footnotetext{
${ }^{37}$ Como Castro (2006:cap.5) observa, o próprio Lyons (1985) reconhece que a distinção entre línguas com genitivos determinantes e línguas com genitivos adjetivais não é rígida. As línguas podem apresentar variação, em determinados contextos. $\mathrm{O}$ italiano e o catalão, por exemplo, permitem um possessivo sem artigo com nomes de parentesco. Nesses termos, os possessivos no português teriam um padrão misto.
} 
Castro propõe que a distinção entre pronomes possessivos fracos e fortes é adequada para o português, embora a língua não apresente formas distintas para os possessivos prénominais (fracos) e pós-nominais (fortes), ao contrário do francês, por exemplo ${ }^{38}$.

No entanto ela se afasta igualmente da proposta de Cardinaletti (1998), ao assumir para o português que os possessivos pré-nominais, embora pronomes fracos, comportam-se como núcleos, sendo gerados em adjunção a $\mathrm{D}$, a posição em que definitude é interpretada. A tipologia agora se baseia na forma dos possessivos, considerando não apenas a morfologia ou distribuição dos possessivos, mas o estatuto categorial em termos da dicotomia núcleo (X) vs. projeção máxima (XP), entre os possessivos pré-nominais que são núcleos e ocupam a posição D, e possessivos pós-nominais que são XPs.

Os argumentos listados abaixo servem para exemplificar o fato de que tanto na variedade lusitana, quanto na variedade brasileira, os possessivos são núcleos, comportandose diferentemente dos possessivos XPs, do tipo italiano.

(i) Possessivos pré-nominais podem coocorrer com advérbios fracos do tipo ainda, já, em adjunção no núcleo D, mas não com advérbios de modo que são XPs ${ }^{39}$

(5) a. a ainda minha mulher

b. a já sua noiva

(ii) Possessivos pré-nominais podem ser focalizados unicamente por acento (prosódia). ${ }^{40}$

(6) Vi os MEUS alunos, não (os) teus.

(iii) O possessivo pré-nominal está estritamente adjacente ao artigo definido, a exceção ocorrendo apenas na presença de alguns advérbios, como mostrado nos exemplos $(5 \mathrm{a}-\mathrm{b})$.

\footnotetext{
${ }^{38}$ Castro (2006) assume que os possessivos apresentam uma natureza dupla em termos dos traços funcionais (pessoa e número), podendo ser, ao mesmo tempo, pronomes (referindo-se ao possuidor), e adjetivos /determinantes (concordando em gênero e número com o possuído).

${ }^{39}$ Castro (2006:68), exemplo 75a e 75.

${ }^{40}$ Castro (2006:68), exemplo 76a .
} 
(iv) Os possessivos pré-nominais são majoritariamente usados com artigos definidos, ao contrário dos pós-verbais que são usados com artigos indefinidos ${ }^{41} 42$.

(7) a. (o) meu livro.

b. um livro meu.

c. *um meu livro

d. um livro meu

Tal restrição se confirma pelo fato de que os demonstrativos - inerentemente definidos - combinam-se (preferencialmente) com possessivos pré-nominais. Além disso os possessivos pré-nominais nunca combinam com determinantes ou modificadores não definidos. Em outras palavras, o possessivo pré-nominal no português é definido de alguma forma, enquanto na posição pós-nominal está associado com a indefinitude. Castro conclui, portanto, que os possessivos prenominais são núcleos ocupando a posição $\mathrm{D}$, em adjunção com o artigo definido e certos advérbios, como se vê na figura (2.5):

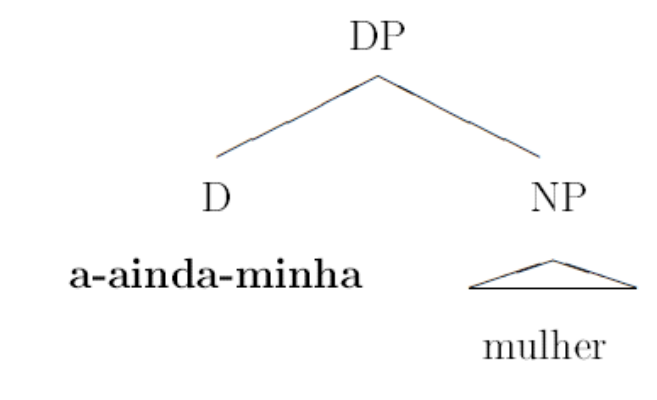

Figura 2.5 - Possessivos pronominais em D ${ }^{43}$

\subsubsection{Sobre a definitude}

No estudo dos possessivos é preciso ainda assumir uma noção de definitude. Nos moldes de Lyons (1999), Castro afirma que a definitude é uma categoria gramatical em línguas que exibem marca de definitude. Em português o marcador é o artigo definido o(s), a(s), introduzindo as frases definidas e sendo localizado na projeção DP.

\footnotetext{
${ }^{41}$ Castro (2006:187), exemplos 286a-b; 287a-b .

${ }^{42}$ A autora faz buscas nos sites do google obtendo evidências de que, tanto no PE quanto no PB, tal tendência se confirma. Cf. Também Neves (1993), com base nos dados do NURC.

${ }^{43}$ Castro (2006:222), exemplo 350 .
} 
Como mencionado anteriormente, Longobardi (1994) classifica os artigos definidos em substantivos e expletivos, ou seja, semanticamente vazios, com base nos seguintes contextos:

(i) os artigos definidos podem contribuir com o seu próprio significado (como operadores) nos usos específicos dos nomes comuns;

(ii) podem ser expletivos ocupando uma posição interpretada na leitura normal dos nomes próprios singulares;

(iii) podem ser expletivos ocupando uma posição semanticamente não interpretada com genéricos.

O autor especifica alguns contextos nos quais um expletivo poderia ocorrer, como 'último recurso', quando a língua não tem movimento de N para D. Esse seria o caso dos sintagmas nominais com nomes próprios de pessoas. Os nomes próprios têm alta referencialidade, portanto, estaria licenciada a presença do artigo para expressar a referencialidade/definitude. No caso do italiano, a língua permite movimento de $\mathrm{N}$ para $\mathrm{D}$, dispensando o artigo expletivo. No PE e PB não há movimento de N para D. Portanto, a presença do artigo expletivo se faz necessária. O mesmo ocorreria no caso dos genéricos.

Inspirada na distinção entre artigo definido substantivo e artigo definido expletivo de Longobardi (1994), e na variação presença vs. ausência do artigo no PE e PB, Castro inclui entre os contextos que requerem artigos expletivos, os DPs com possessivo pré-nominal. Neste caso, não é o artigo definido o elemento marcador da interpretação definida do sintagma nominal, uma vez que o possessivo que ocupa a posição $\mathrm{D}$, produz o mesmo efeito. Vejamos cada um deles.

(i) No interior dos sintagmas nominais o possessivo pré-nominal pode ocorrer sem artigo definido no PB (8a), mas não no PE (8b). ${ }^{44}$

(8) a. Meu livro tem 100 páginas.

b. O meu livro tem 100 páginas.

\footnotetext{
${ }^{44}$ Castro (2006:233), exemplos 357 a-b .
} 
(ii) o artigo definido pode estar ausente com nomes próprios de pessoas no PB (9a). No PE, porém, ele é obrigatório $(9 b){ }^{45}$

(9) a. Joaquinita fazia anos amanhã.

b. A Joaquinita fazia anos amanhã.

(iii) Na posição de sujeito as frases nominais requerem artigo definido no PE, no contexto de predicados individuais e de espécie (kind) (10a-b), enquanto no PB pode apresentar um Nome Nu (Bare Noun) (11a-b): ${ }^{46}$

(10) a. Os elefantes são inteligentes.

b. Os elefantes estão extintos.

(11) a. Elefantes são inteligentes.

b. Elefantes estão extintos.

(iv) Nos sintagmas nominais com interpretação genérica, o PB apresenta Nomes Nus, tanto no singular como no plural (13a,b-c), enquanto o PE exige um artigo definido, em caso correlato a $(12 \mathrm{a}):^{47}$

(12) a. Criança lê revistinha.

b. Crianças lêem revistinhas.

c. As crianças lêem revistinhas.

Dentro do quadro da Teoria dos Princípios e Parâmetros, o que Castro defende, portanto, é que o contraste presença versus a ausência de artigo definido diante de possessivos pré-nominais no PE e PB não resulta de diferenças na gramática dos possessivos. Antes o que distingue as duas variedades é a realização do artigo definido expletivo que tanto nas nominais possessivas, quanto nos genéricos e com nomes próprios, pode ser foneticamente nulo em PB e obrigatoriamente realizado em PE.

Castro (2006) reforça a sua hipótese lembrando do fato adicional que marca as duas

\footnotetext{
${ }^{45}$ Castro (2006:235), exemplos $362 \mathrm{a}-\mathrm{b}$.

${ }^{46}$ Castro (2006:240), exemplos 366a-b e 367 a-b .

47 Castro (2006:240/241), exemplos 368a-b e 379 .
} 
variedades do português: enquanto no PE, as marcas de número estão presentes em todos os elementos do sintagma nominal (13a-b), em algumas variedades do PB, podem ocorrer em um único elemento (14a). ${ }^{48} \mathrm{O}$ que chama a atenção é que quando um possessivo pré-nominal ocorre, é ele e não o artigo que aloja a marca de plural (15b). ${ }^{49}$

(13) a. os primeiros filhos

b. os meus filhos

(14) a. os primeiro filho

b. o meus filho

Considerando que no português a expressão de número semanticamente relevante é codificado em D, Castro assume a análise para a variação micro-paramétrica entre PE e PB de Costa \& Figueiredo Silva (2006). Esta análise baseia-se no modelo da Morfologia Distribuída e assume que o morfema de plural pode ser singleton (realizado uma vez, no núcleo relevante) ou morfema dissociado/copiado para outros núcleos.

A proposta de Castro é a de que, numa língua com morfema plural singleton, como é o caso do PB, número é realizado em D. O contraste acima pode ser explicado pela natureza diferente dos dois artigos: (14a) contém um artigo substantivo responsável pela marcação de definitude e a marca de pluralidade; (14b) contém um artigo expletivo sem conteúdo semântico: neste caso é o possessivo, que acumula a codificação da definitude, e a expressão semântica de pluralidade.

\subsection{O estudo de Rinke: um panorama diacrônico desde o português arcaico}

Rinke (2010) dedica-se ao estudo da combinação de artigo definido e pronome possessivo na história do PE, mais especificamente, entre os séculos XIII e XIX. Como se sabe, na fase arcaica da língua (séculos XIII e XIV) ${ }^{50}$, o artigo definido é sistematicamente omitido na presença dos possessivos. No entanto, como já discutido, ao longo do tempo os textos escritos por portugueses revelam uma mudança importante que é a presença praticamente categórica do artigo definido diante dos possessivos. Comparem-se os exemplos

\footnotetext{
${ }^{48}$ Este fato foi apresentado e discutido na revisão de Floripi (2008).

49 Castro (2006:277), exemplos 379a-b e 380a .

50 Cf. Mattos \& Silva (1989), entre outros.
} 
(15a) e (15b), os quais ilustram o contraste entre o PE e o português arcaico (PA), sugerindo uma mudança linguística no que se refere à combinação do artigo com o possessivo. ${ }^{51}$

(15) a. Comecei a minha vida sem nada e hoje sou um grande lavrador,... (CORDIALSIN, 1992)

b. e por ua casa c(on) sua q(ui)ntaa q(ue) foy de nosso padre e de nossa madre...

(doc. 1266, Martins 2001)

Considerando que é importante ter uma base de dados para a investigação diacrônica dos possessivos, Rinke faz uso de um corpus formado por 1632 frases nominais do século XIII ao século XX, provenientes do norte de Portugal e da região de Lisboa, publicada por Martins (2001). Abaixo reproduzimos seu diagrama 2.1 e seus resultados:

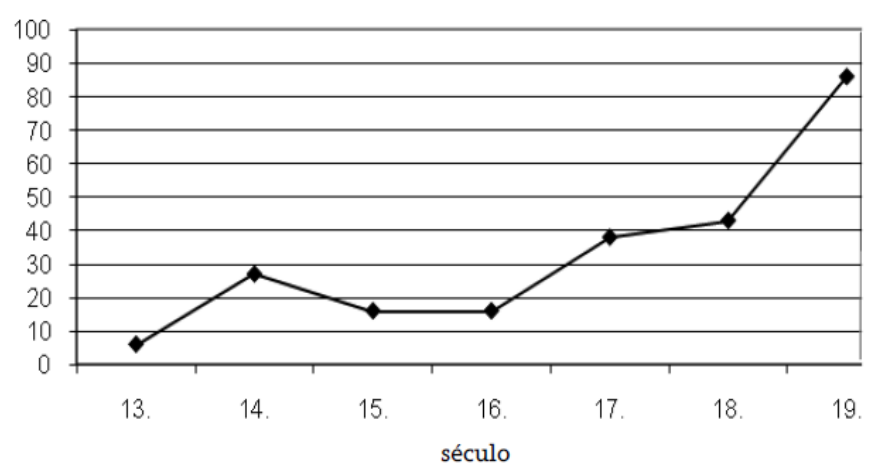

Diagrama 2.4.1 Proporção de frases nominais possessivos com artigo definido ${ }^{52}$

Pelo gráfico, vê-se que, no século XIII, o artigo está categoricamente ausente nos contextos possessivos. Já no final do século XIX, atinge quase a totalidade dos dados. Há um período, entre os séculos XVI e XVIII em que a ocorrência do artigo é variável, sendo a sua omissão quantitativamente dominante até o século XVIII. Fica fácil observar que o gráfico de Rinke, embora mais abrangente em termos de período histórico e com base em documentação distinta, apresenta a mesma curva ascendente desenhada a partir dos resultados de Floripi (2008), ou seja, a mudança em direção à implementação do artigo diante do possessivo na história do PE.

Rinke destaca, porém, que no aspecto diacrônico é preciso reconhecer que os autores do século XIX se caracterizaram por um uso inovador e arcaizante no uso dos artigos diante

\footnotetext{
${ }^{51}$ Rinke (2010:122), exemplos 1 a -b.

${ }^{52}$ Rinke (2010:130), diagrama 1.
} 
dos possessivos. No entanto, a autora conclui que tal coexistência de dois estados linguísticos não refletem opcionalidade no uso do artigo, que caracterizou gramaticamente o período arcaico. Um outro aspecto da mudança diacrônica que ela destaca é o de que, ao contrário do português arcaico, a fase atual do português (e podemos lembrar que isso vale tanto para o PE como para o PB), obriga a que o possessivo pré-nominal seja precedido por artigo definido.

Vale destacar que um outro ponto importante discutido pela autora a respeito da fase arcaica do português é o da existência de formas femininas fracas/ átonas, ma (mha), ta, sa , no século XIII e XIV, ao lado de formas fortes/ tônicas, minha, tua, sua, que se tornam categóricas no século XV, como mostrado em Mattos e Silva (1989, 1993). A autora registra ainda a proposta de Miguel (2002a) e Brito (2007), segundo as quais o português arcaico possuía três paradigmas de possessivos: a) uma série de possessivos pré-nominais clíticos que ocorrem sem artigo e podem ser duplicados pela forma pronominal dele; b) uma série átona de possessivos pré-nominais fracos, com artigos e em construções elípticas; c) uma série de formas fortes pós-nominais e predicativas.

Relativamente à análise dos possessivos no português e nas línguas românicas em geral, a autora destaca que dois aspectos distintos, mas interdependentes, têm chamado a atenção dos pesquisadores: a) o estatuto categorial dos possessivos como adjetivos ou determinantes e b) a caracterização dos possessivos como elementos fracos ou fortes. ${ }^{53}$

Como ela esclarece, a progressiva combinação do pronome possessivo com o artigo definido, na história do PE, pode estar refletindo: (i) ou uma mudança categorial no estatuto dos possessivos; (ii) ou a extensão do emprego do artigo aos contextos possessivos.

No segundo caso, teríamos um processo de gramaticalização do próprio artigo definido. Ou seja, o artigo definido teria surgido primeiramente como marcador de um tópico discursivo, ou informação dada, a partir de contextos específicos (definidos e indefinidos), para os contextos não específicos, e se estenderia depois a todos os contextos em que um sintagma nominal possessivo é interpretado como definido. A autora assume que a segunda interpretação é a adequada.

De fato, Rinke observa que, no século XIV, o emprego do artigo definido parte de contextos nos quais o falante põe em relevo a referência anafórica de uma frase nominal com pronome possessivo. Uma evidência vem do fato de que o uso do artigo definido com

\footnotetext{
${ }^{53}$ Lembramos que Lyons (1985) propõe que as línguas dividem-se tipologicamente em línguas que permitema combinação do artigo definido com o possessivo (adjectival-genitive- (AG-)languages) e línguas de genitivos determinantes (determinative-genitive-languages- (DG-)languages), as quais não a permitem. A classificação de Lyons corresponde ao parâmetro de possessivação (possessive parameter) proposto por Giorgi e Longobardi (1991).
} 
possessivo é combinado com os adjetivos dito/dicto ou sobredito/sobredicto, abaixo exemplificado. $^{54}$

(16) Emp(ra)zo A uos (e) //ha// Aa d(i)ta vossa molher (e) pessoa depos uos, os d(i)tos talhos de ujnha (doc. 1363, Martins 2001)

Em outras palavras, a proposta de Rinke é a de que o artigo definido tenha primeiramente surgido como marcador de um tópico discursivo, gramaticalizando-se, posteriormente, como o elemento que realiza morfologicamente a definitude. A mudança linguística observada no que se refere ao artigo nos contextos possessivos não refletiria uma mudança categorial do possessivo e também não estaria relacionada com a perda de um paradigma de formas possessivas fracas e fortes. ${ }^{55}$ Ao contrário, a mudança linguística, consiste no processo de gramaticalização do demonstrativo do latim e de sua reanálise como artigo definido nas línguas românicas (núcleo da categoria DP). ${ }^{56}$

Tal mudança, segundo a autora, caracteriza-se por uma longa fase de variação, na qual a marcação de um possessivo como definido é opcional. O núcleo do DP possessivo pode ser ocupado por um artigo definido, lexicalmente realizado ou vazio, sendo a segunda opção a que se verifica no latim e nas línguas que não dispõem de artigos lexicais. A estrutura que a autora tem em mente para os possessivos e determinantes no PE toma como base Schoorlemmer 1998: ${ }^{57}$

\footnotetext{
${ }^{54}$ cf. Rinke (2010:132), exemplo 17a.

${ }^{55}$ Na verdade, Rinke retoma Castro \& Costa (2003) e Castro (1996) em sua discussão de que os possessivos prénominais no português não se encaixariam nem na tipologia dos pronomes fortes e fracos, nem numa classificação tradicional como adjetivos. A autora enfatiza que os possessivos do português, embora apresentem certos paralelismos com adjectivos, têm propriedades particulares. Além disso, não podem ser classificados nem substituem determinantes, porque ocorrem em posições não argumentais que, seguindo Longobardi (1994), a autora reconhece que não dispõem da categoria $\mathrm{D}$, entre eles, os contextos apositivos, predicativos, vocativos, e outros.

${ }^{56}$ Para a sua hipótese da gramaticalização do artigo definido a autora se baseia em em Roberts \& Rousseau (2007).

${ }^{57}$ Rinke (2010:122), sem numeração no original.
} 


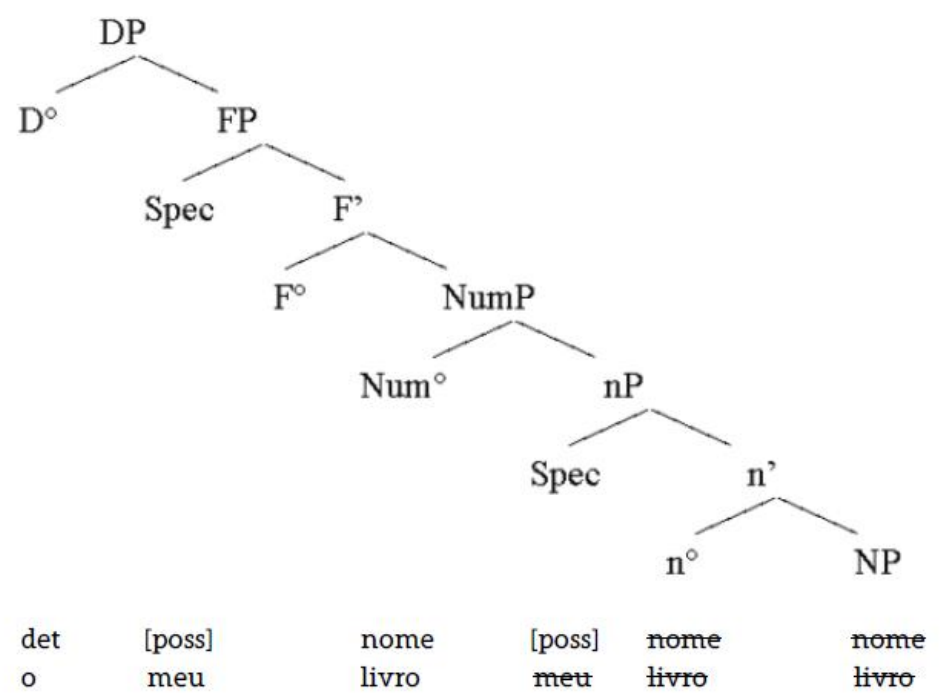

Figura 2.6: Possessivo NP com definido opcional

No âmbito dessa estrutura, o possessivo pode ocupar duas posições distintas: ou a sua posição básica (SpecNP), no caso de ser pós-nominal, ou o especificador da categoria FP em posição pré-nominal. A diferença entre o português e o italiano consiste nos fatores que determinam a posição dos possessivos: a estrutura informacional no caso do italiano e a definitude do sintagma nominal no caso do português.

\begin{abstract}
A análise implica que a presença/ausência do artigo não indica o estatuto categorial do possessivo como adjectivo ou determinante, porque os artigos definidos podem não ser utilizados em línguas que dispõem de possessivos inequivocamente adjectivais. Além disso, a variação tipológica também não se relaciona com o estatuto forte ou fraco das formas possessivas, visto que tanto os possessivos fracos como os possessivos fortes podem ocorrer com ou sem artigo. Com base nesta argumentação, podemos concluir que o estatuto de determinante de um possessivo corresponde tipologicamente à ausência do artigo (Lyons 1986), embora a omissão do artigo não implique que os possessivos de uma dada língua sejam determinantes.
\end{abstract}

(Rinke (2010:121).

Assim, a autora identifica o contraste entre o português medieval e o PE, pelo fato de que, na fase moderna do português, o artigo definido acompanha sistematicamente as expressões nominais com possessivo pré-nominal, sendo porém, sistematicamente omitido no português antigo. Em termos de implementação da mudança, observou-se pela sua abordagem quantitativa que, a partir do século XIV, existe uma fase de variação, na qual o emprego do artigo é opcional. No século XIX, o uso do artigo em combinação com os pronomes possessivos generaliza-se, com exceção dos termos de parentesco. 


\subsection{O estudo de Costa (2002): novas informações a respeito do português arcaico}

Tendo como um dos objetivos prioritários de sua pesquisa estabelecer os fatores morfossintáticos que favorecem a presença ou a ausência do artigo definido em DPs possessivos, e DPs que têm como núcleo um nome próprio de pessoa no português arcaico (PA), Costa (2002) traz conclusões que são relevantes à nossa pesquisa. A autora reconhece ainda os dois conhecidos fatos a respeito do PA: (i) a presença do artigo é variável diante do possessivo; (ii) há um percentual mais alto de apagamento do artigo.

Na busca dos seus objetivos, Costa analisa quatro textos escritos entre os séculos XIII e XVI. Como ela esclarece, alguns critérios foram bastante relevantes na seleção das obras que viriam a constituir o corpus. Primeiramente foram selecionados textos que cobrissem o período histórico, entre os séculos XIII e XVI. Depois houve a necessidade de que os textos fossem de diferente natureza, o que resultou no seguinte elenco:

(i) 32 documentos notariais editados por Clarinda Maia (TCM).

(ii) Crônica de D. Pedro (CDP), escrita por Fernão Lopes.

(iii) Diálogo da Viçiosa Vergonha (DVV) e

(iv) Diálogo em Louvor de Nossa Linguagem (DLNL), ambos de autoria de João de Barros.

$\mathrm{Na}$ análise do corpus, a autora considera seis contextos a serem investigados em DPs possessivos, considerando a presença/ausência de artigo:

(i) pessoa do possessivo;

(ii) número do possessivo;

(iii) tipo do sintagma;

(iv) tipo de preposição;

(v) formas como a preposição se apresenta e

(vi) função sintática do sintagma nominal.

A autora observa que, embora seja marcante a superioridade percentual da ausência do clítico com possessivos em todos os textos consultados, o percentual da presença aumenta nos textos do final do período arcaico, século XVI, com os textos escritos por João de Barros: DVV: 28,57\%; DLNL: 37,87\%. Assim, de um total de 1384 ocorrências, 1200 (84,56\%) foram de possessivo não antecedido de artigo, havendo apenas $184(12,96 \%)$ de possessivo 
antecedido de artigo. A Tabela (2.2) e o Gráfico (2.1) fornecem os seguintes dados:

\begin{tabular}{l|r|r|r|r|r|r|r|r|r|r}
\hline & \multicolumn{2}{|c|}{ TCM } & \multicolumn{2}{c|}{ CDP } & \multicolumn{2}{c|}{ DW } & \multicolumn{2}{|c|}{ DLNL } & \multicolumn{2}{|c}{ TOTAL } \\
\cline { 2 - 11 } & OC & \multicolumn{1}{c|}{$\%$} & OC & \multicolumn{1}{c}{$\%$} & OC & $\%$ & OC & $\%$ & OC & $\%$ \\
\hline Poss. c/ art. & 54 & 12,64 & 53 & 7,12 & 52 & 28,57 & 25 & 37,87 & 184 & 12,96 \\
\hline Poss. s/ art. & 340 & 79,62 & 689 & 92,60 & 130 & 71,42 & 41 & 62,12 & 1200 & 84,56 \\
\hline Art. + det. + poss. & 33 & 7,72 & 2 & 0,26 & 0 & 0 & 0 & 0 & 35 & 2,46 \\
\hline
\end{tabular}

Tabela 2.2 - Ocorrências de artigo definido diante de possessivo ${ }^{58}$

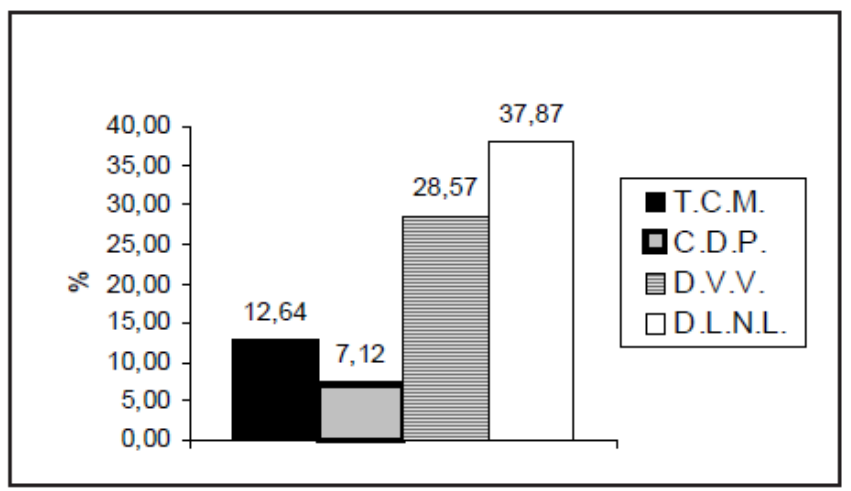

Gráfico 2.1 - Ocorrências de artigo definido diante de possessivo ${ }^{59}$

A seguir vejamos o que foi exposto na tabela 2.3 e gráfico 2.2, nos quais estão computados os resultados percentuais relativos ao diferentes tipos de possessivos no conjunto das obras pesquisadas por Costa:

\begin{tabular}{l|r|c|r|r|r|r|r|r|r|r}
\hline & \multicolumn{2}{|c|}{ TCM } & \multicolumn{2}{c|}{ CDP } & \multicolumn{2}{c|}{ DVV } & \multicolumn{2}{c|}{ DLNL } & \multicolumn{2}{c}{ TOTAL } \\
\cline { 2 - 12 } & OC & \multicolumn{1}{c|}{ OC } & $\%$ & OC & $\%$ & OC & $\%$ & OC & $\%$ \\
\hline meu(s), minha(s) & 10 & 18,51 & 2 & 3,77 & 8 & 15,38 & 1 & 4,00 & 21 & 11,41 \\
\hline nosso(s), nossa(s) & 10 & 18,51 & 6 & 11,32 & 4 & 7,69 & 10 & 40,00 & 30 & 16,30 \\
\hline teu(s), tua(s) & 0 & 0 & 2 & 3,77 & 11 & 21,15 & 0 & 0 & 13 & 7,06 \\
\hline vosso(s), vossa(s) & 6 & 11,11 & 5 & 9,43 & 1 & 1,92 & 0 & 0 & 12 & 6,52 \\
\hline seu(s), sua(s) & 28 & 51,85 & 38 & 71,69 & 28 & 53,84 & 14 & 56,00 & 108 & 58,69 \\
\hline
\end{tabular}

Tabela 2.3 - Possessivos detectados nas obras pesquisadas por Costa ${ }^{60}$

\footnotetext{
${ }^{58}$ Costa (2002:289), tabela 1.

${ }^{59}$ Costa (2002:289), gráfico 3 .

${ }^{60}$ Costa (2002:291), tabela 2 .
} 


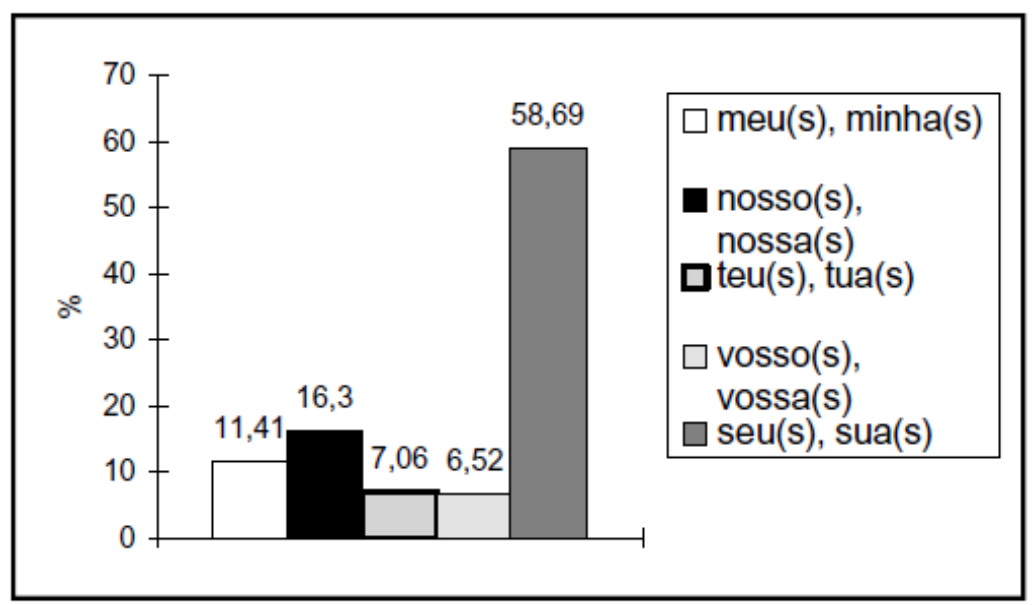

Gráfico 2.2 - Possessivos detectados nas obras pesquisadas por Costa ${ }^{61}$

Como a autora comenta, a exposição dos resultados mostra que os textos consultados favoreceram a marcante supremacia dos percentuais de ocorrências dos possessivos seu(s), sua(s) frente aos alcançados pelos demais possessivos. Também é possível perceber que os pronomes vosso(s), vossa(s) seguidos dos pronomes teu(s), tua(s) mostraram um rendimento menor se comparados aos outros possessivos.

Por sua vez, os resultados obtidos com a variável número (singular /plural) evidenciam que há uma superioridade absoluta de ocorrências no singular no uso do possessivo com artigo em todos os textos - conforme demonstra a tabela (2.4) e gráfico (2.3). Observe-se que o percentual da variável singular chega a atingir $96 \%$ no DLNL.

\begin{tabular}{l|r|c|r|r|r|r|r|r|r|r}
\hline \multirow{2}{*}{} & \multicolumn{2}{|c|}{ TCM } & \multicolumn{2}{c|}{ CDP } & \multicolumn{2}{c|}{ DVV } & \multicolumn{2}{c}{ DLNL } \\
\cline { 2 - 11 } & OC. & $\%$ & OC. & $\%$ & OC. & $\%$ & OC & $\%$ & \multicolumn{1}{c}{ OC } & \multicolumn{1}{c}{$\%$} \\
\hline Singular & 42 & 77,77 & 41 & 77,35 & 36 & 69,23 & 24 & 96,00 & 143 & 77,71 \\
\hline Plural & 12 & 22,22 & 12 & 22,64 & 16 & 30,76 & 1 & 4,00 & 41 & 22,28 \\
\hline
\end{tabular}

Tabela 2.4 - Ocorrências de singular e plural no uso dos possessivos nas obras pesquisadas por Costa ${ }^{62}$

\footnotetext{
${ }^{61}$ Costa (2002: 291), gráfico 6 .
}

${ }^{62}$ Costa (2002:292), tabela 3. 


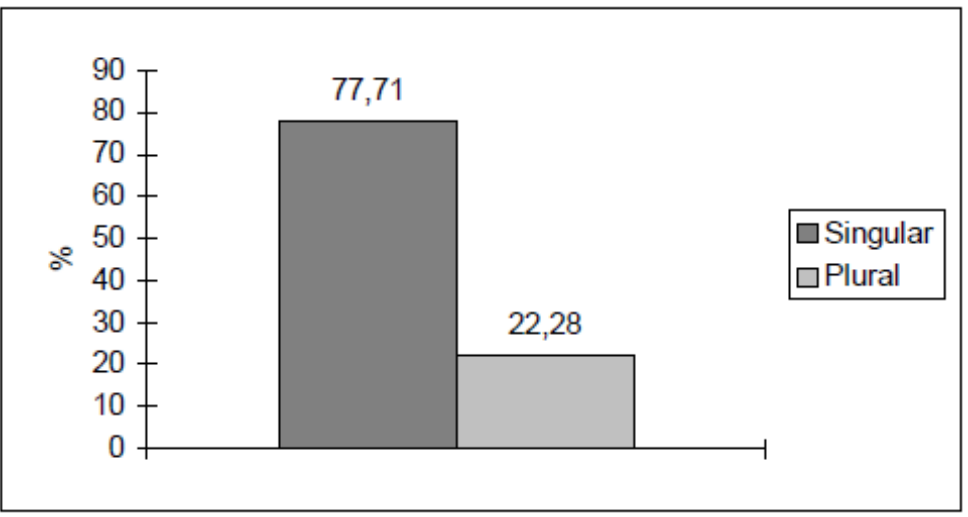

Gráfico 2.3 - Ocorrências de singular e plural no uso dos possessivos nas obras pesquisadas por Costa ${ }^{63}$

O terceiro contexto identificado por Costa, tipos de sintagma, se refere à proeminência do sintagma preposicionado nas ocorrências de possessivo com artigo, a qual a autora conclui como sendo irrefutável em todos os textos analisados. Como veremos no capítulo 4, onde expomos os resultados percentuais obtidos com o nosso corpus, a presença da preposição vai ser igualmente relevante para o favorecimento da realização do artigo definido frente ao possessivo. Vejamos a tabela (2.5) e o gráfico (2.4) abaixo:

\begin{tabular}{l|r|c|r|c|r|r|r|r|r|c}
\hline & \multicolumn{2}{|c|}{ TCM } & \multicolumn{2}{c|}{ CDP } & \multicolumn{2}{c|}{ DVV } & \multicolumn{2}{c}{ DLNL } & \multicolumn{2}{c}{ TOTAL } \\
\cline { 2 - 12 } & OC & \multicolumn{1}{c|}{ OC } & \multicolumn{1}{c|}{$\%$} & OC & $\%$ & OC & $\%$ & OC & $\%$ \\
\hline Preposicionado & 43 & 79,62 & 34 & 64,15 & 30 & 57,69 & 15 & 60,00 & 122 & 66,30 \\
\hline Nominal & 11 & 20,37 & 19 & 35,84 & 22 & 42,30 & 10 & 40,00 & 62 & 33,69 \\
\hline
\end{tabular}

Tabela 2.5 - Ocorrências de possessivo com artigo em SNs e SPreps ${ }^{64}$

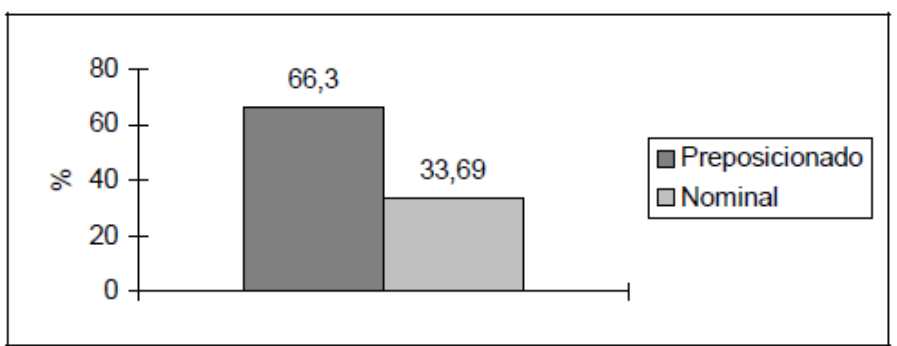

Gráfico 2.4 - Ocorrências de possessivo com artigo em SNs e SPreps ${ }^{65}$

\footnotetext{
${ }^{63}$ Costa (2002:292), gráfico 9 .

${ }^{64}$ Costa (2002:293), tabela 4 .

${ }^{65}$ Costa (2002:293), gráfico 12 .
} 
O quarto contexto, tipos de preposição, mostra que o percentual total de uso da preposição de em ocorrências de possessivo com artigo é superior ao total de todas as outras preposições em conjunto. A exposição dos resultados está na tabela (2.6) e gráfico (2.5):

\begin{tabular}{l|r|r|r|r|r|r|r|r|r|r}
\hline & \multicolumn{2}{|c|}{ TCM } & \multicolumn{2}{c|}{ CDP } & \multicolumn{2}{c|}{ DVV } & \multicolumn{2}{c}{ DLNL } & \multicolumn{2}{c}{ TOTAL } \\
\cline { 2 - 13 } & OC & \multicolumn{1}{c}{$\%$} & OC & $\%$ & OC & $\%$ & OC & $\%$ & OC & $\%$ \\
\hline de & 32 & 74,41 & 19 & 55,88 & 15 & 50,00 & 11 & 73,33 & 77 & 63,74 \\
\hline a & 6 & 13,95 & 10 & 29,41 & 9 & 30,00 & 2 & 13,33 & 27 & 22,13 \\
\hline em & 2 & 4,65 & 3 & 8,82 & 4 & 13,33 & 2 & 13,33 & 11 & 9,16 \\
\hline perante & 1 & 2,32 & 0 & 0 & 0 & 0 & 0 & 0 & 1 & 0,81 \\
\hline com & 1 & 2,32 & 1 & 2,94 & 0 & 0 & 0 & 0 & 2 & 1,63 \\
\hline por & 1 & 2,32 & 0 & 0 & 0 & 0 & 0 & 0 & 1 & 0,81 \\
\hline ante & 0 & 0 & 0 & 0 & 1 & 3,33 & 0 & 0 & 1 & 0,81 \\
\hline até & 0 & 0 & 1 & 2,94 & 0 & 0 & 0 & 0 & 1 & 0,81 \\
\hline conforme & 0 & 0 & 0 & 0 & 1 & 3,33 & 0 & 0 & 1 & 0,81 \\
\hline
\end{tabular}

Tabela 2.6 - Ocorrências de preposições em contexto de possessivos com artigo ${ }^{66}$

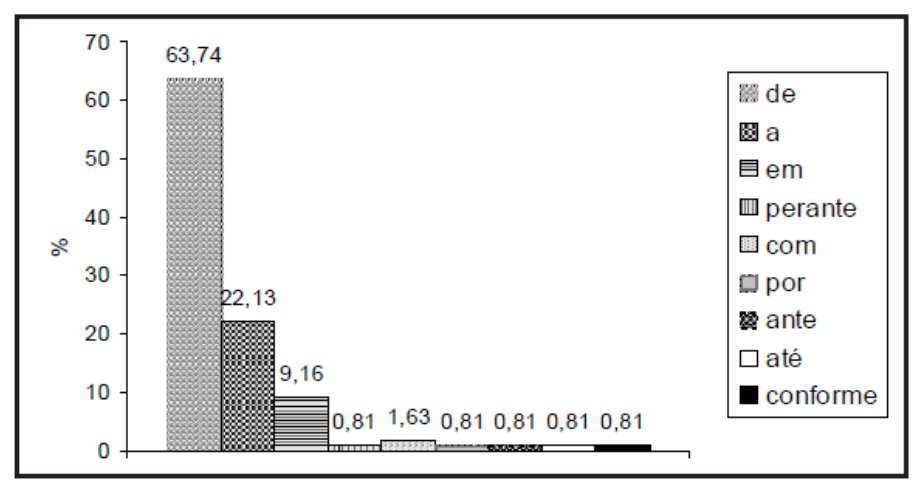

Gráfico 2.5 - Ocorrências de preposições em contexto de possessivos com artigo ${ }^{67}$

Por sua vez, o quinto contexto que se refere às formas nas quais a preposição se apresenta, evidencia o fato de que preposições que se contraem favorecem muito mais o uso do artigo definido diante de possessivo de uma maneira geral. A tabela (2.7) e gráfico (2.6) comprovam essa supremacia:

\begin{tabular}{r|r|c|r|r|r|r|r|r|r|r}
\hline & \multicolumn{2}{|c|}{ TCM } & \multicolumn{2}{c|}{ CDP } & \multicolumn{2}{c|}{ DW } & \multicolumn{2}{c|}{ DLNL } & \multicolumn{2}{c}{ TOTAL } \\
\cline { 2 - 11 } & OC & $\%$ & OC & $\%$ & OC & $\%$ & OC & $\%$ & OC & $\%$ \\
\hline Contraídas & 38 & 88,37 & 32 & 94,11 & 27 & 90,00 & 14 & 93,33 & 111 & 90,98 \\
\hline Não contraídas & 5 & 11,62 & 2 & 5,88 & 3 & 10,00 & 1 & 6,66 & 11 & 9,01 \\
\hline
\end{tabular}

Tabela 2.7 - Ocorrências de preposições contraídas e não-contraídas no contexto pesquisado 68

\footnotetext{
${ }^{66}$ Costa (2002:294), tabela 5.

${ }^{67}$ Costa (2002:295), gráfico 15.

${ }^{68}$ Costa (2002:296), tabela 6.
} 


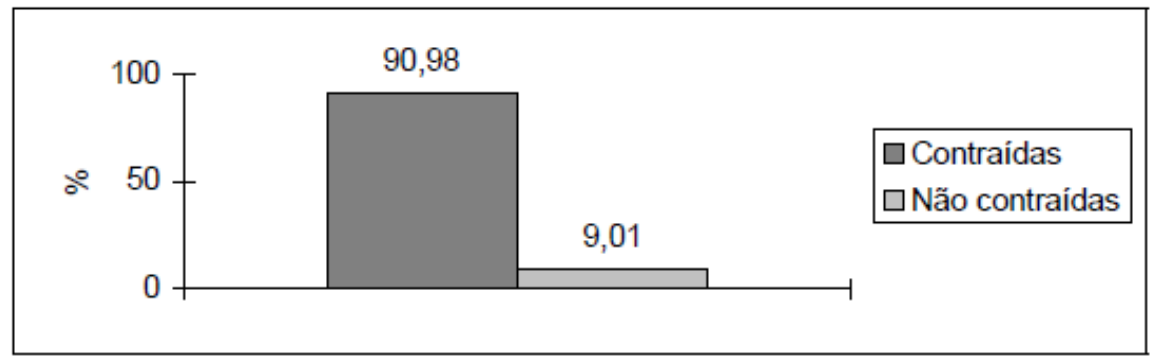

Gráfico 2.6 - Ocorrências de preposições contraídas e não-contraídas no contexto pesquisado ${ }^{69}$

O sexto contexto, função sintática do sintagma nominal, demonstra terem sido as funções de sujeito e de objeto direto as que obtiveram maior índice no uso do artigo diante de possessivo em todos os textos estudados por Costa, conforme comprovam tabela (2.8) e gráfico (2.7) que se seguem:

\begin{tabular}{l|r|c|r|r|r|r|r|r|r|r}
\hline & \multicolumn{2}{|c|}{ TCM } & \multicolumn{2}{c|}{ CDP } & \multicolumn{2}{c|}{ DW } & \multicolumn{2}{c|}{ DLNL } & \multicolumn{2}{c}{ TOTAL } \\
\cline { 2 - 12 } & OC & \multicolumn{1}{c|}{ OC } & \multicolumn{1}{c|}{$\%$} & OC & $\%$ & OC & $\%$ & OC & $\%$ \\
\hline Objeto direto & 8 & 72,72 & 8 & 42,10 & 13 & 59,09 & 5 & 50,00 & 34 & 54,83 \\
\hline Sujeito & 3 & 27,27 & 10 & 52,63 & 8 & 36,36 & 4 & 40,00 & 25 & 40,32 \\
\hline Predicativo & 0 & 0 & 1 & 5,26 & 1 & 4,54 & 1 & 10,00 & 3 & 4,83 \\
\hline
\end{tabular}

Tabela 2.8 - Ocorrências de preposições contraídas e não-contraídas no contexto pesquisado ${ }^{70}$

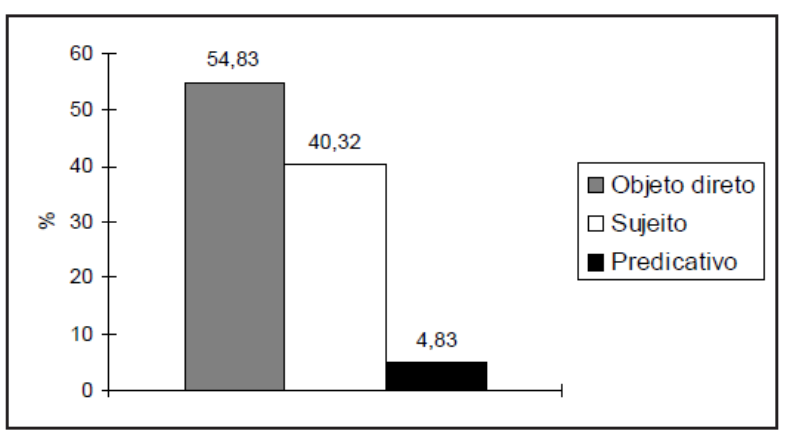

Gráfico 2.7 - Ocorrências de preposições contraídas e não-contraídas no contexto pesquisado ${ }^{71}$

Concluindo a apresentação de Costa (2002), queremos considerar duas afirmações feitas pela autora: (i) a de que o contexto mais relevante entre os apresentados é o da presença da preposição, que vem a ser um estímulo para o uso do artigo definido; (ii) a de que o uso do artigo definido diante do possessivo aumentou mais no final do período arcaico.

O item (i) seria surpreendente, uma vez que os resultados encontrados com relação ao uso da preposição são contrários aos das outras pesquisas sobre o assunto, em que a

\footnotetext{
${ }^{69}$ Costa (2002:296), gráfico 16.

${ }^{70}$ Costa (2002:297), tabela 7.

${ }^{71}$ Costa (2002:297), gráfico 21.
} 
preposição costuma inibir o uso do artigo e não estimulá-lo. Em Floripi (2008) há menção ao erro encontrado nas tabelas de Costa (2002) e, com uma leitura atenta, a autora percebeu que os dados de Costa (2002) correspondem à quantificação do total de ocorrências de DPs preposicionados ou não, considerando sempre a presença do artigo. Dessa forma, esses resultados não contemplariam a variação do uso do artigo, mas a possibilidade do DP possessivo vir precedido por uma preposição ou não (cf. FLORIPI (2008) p. 114).

Portanto, mesmo sem apresentar uma análise sobre a estrutura do DP possessivo, os resultados de Costa propiciam uma confirmação de outros estudos a respeito do fato de que uma mudança nos padrões de aplicação do artigo na língua já estava tomando forma antes do século XV, intensificando-se ao longo do tempo.

\subsection{Brito (2007) e a estrutura do DP}

Assim como Miguel (2002a), Brito (2007) reconhece 3 gramáticas em competição para os possessivos pré-nominais no PE, com estatuto distinto. Uma delas, uma gramática dialetal, de língua falada, na qual os possessivos são quase clíticos ao artigo definido, podem ser reduzidos e devem ocupar a posição D. Outras duas gramáticas, uma dominante e outra mais conservadora/formal, são descritas a partir dos testes apresentados em Costa \& Castro (2003) e Castro (2007). Assim Brito assume que o que diferencia as duas outras gramáticas é o fato de a gramática não dominante/conservadora, ao contrário da dominante, permitir que certos advérbios (a ainda minha mulher) e alguns outros elementos interrompam a adjacência obrigatória do artigo e possessivo. As duas gramáticas também se distanciariam na medida em que a mais conservadora aceita indefinidos antes dos possessivos (uns meus livros).

Vale ressaltar que a proposta formulada por Brito para as gramáticas dos possessivos no PE tem uma perspectiva distinta. Ela afirma que uma análise sintática tem que levar em conta não apenas a natureza externa dos possessivos (como X ou XP), mas a dualidade de sua natureza interna, ou seja, a natureza pronominal e adjetival. De fato, como ela discorre, as formas possessivas expressam uma dupla dimensão. A primeira é uma relação com as 3 pessoas do discurso, no singular e no plural. A segunda relaciona o possuidor às entidades designadas pelo núcleo nominal, apresentando concordância em gênero e número (o/os meu (s) amigo (s); a/as minha(s) amiga (s)). Nessa última dimensão, expressam concordância com

o objeto possuído. A autora lembra ainda que, com relação aos traços semânticos dos possessivos, o traço [+ específico] tem uma natureza de traço "default". Dependendo das 
línguas, porém, os possessivos podem expressar ainda valores de definitude (francês, espanhol, inglês), enquanto outras não são especificadas em relação a esse traço.

Nos termos de Déchaine and Wiltschko (2003), a autora assume que, por sua natureza morfológica e sintaxe interna, os possessivos são uniformemente coleções de traços $(\phi \mathrm{P})$, variando nas diferentes línguas na sua sintaxe externa, ou seja, no seu estatuto como adjetivo ou determinante. A pergunta que se segue naturalmente é a que foi levantada pela maioria dos estudos acima resenhados a respeito do sistema possessivo do PE: os possessivos pré-nominais são adjetivos ou determinantes? Partindo da constatação de que há um situação de variação entre as línguas românicas, e mesmo dentro de uma mesma língua, a respeito da presença vs. ausência do artigo diante dos possessivos pré-nominais, é possível argumentar que eles variam na sua natureza como D ou como A. No entanto, como Brito lembra, no programa minimalista (cf. Chomsky 2000), a variação e a microvariação no sistema possessivo entre gramáticas não se deve ao diferente estatuto categorial das palavras (contra o parâmetro de Giorgi \& Longobardi 1990), mas aos traços das categorias funcionais. Portanto, o que se tem que considerar é a natureza e os traços de D, em particular, se D tem material lexical ou não, quais traços D codifica, e em como se realizam as operações de checagem dos traços de concordância (caso, número, e pessoa) em cada gramática, com consequências para as diferentes operações computacionais.

Com base na hipótese do DP universal proposta em Longobardi (1994) e nas propostas de projeções funcionais entre DP e NP para as operações de checagem dos traços de Pessoa e Número, além de uma projeção para gerar o possessivo pré-nominal (PossP), a autora propõe a seguinte estrutura para a gramática dialetal:

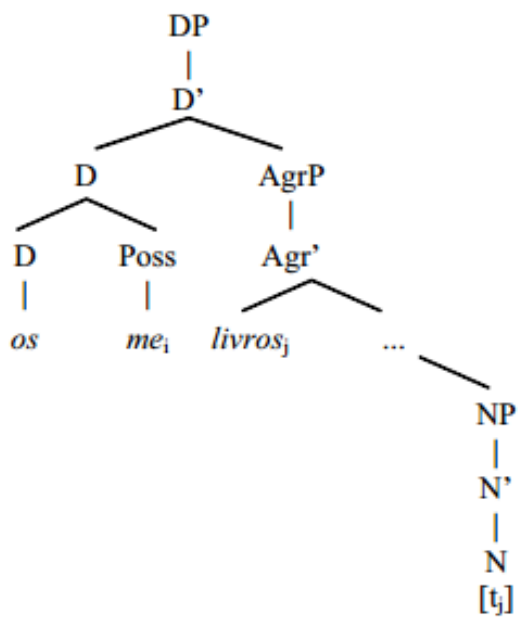

Figura 2.7: Estrutura da gramática dialetal do $\mathrm{PE}^{72}$

\footnotetext{
${ }^{72}$ Brito (2007:44), figura 64 .
} 
Na gramática dialetal, os possessivos são sempre definidos e clíticos. A motivação de seu movimento para $\mathrm{D}$ é o traço [+ definido] do núcleo determinante.

E como seria a estrutura que representa a sintaxe do DP na gramática não dominante? Brito propõe a que está representada em (2.8):

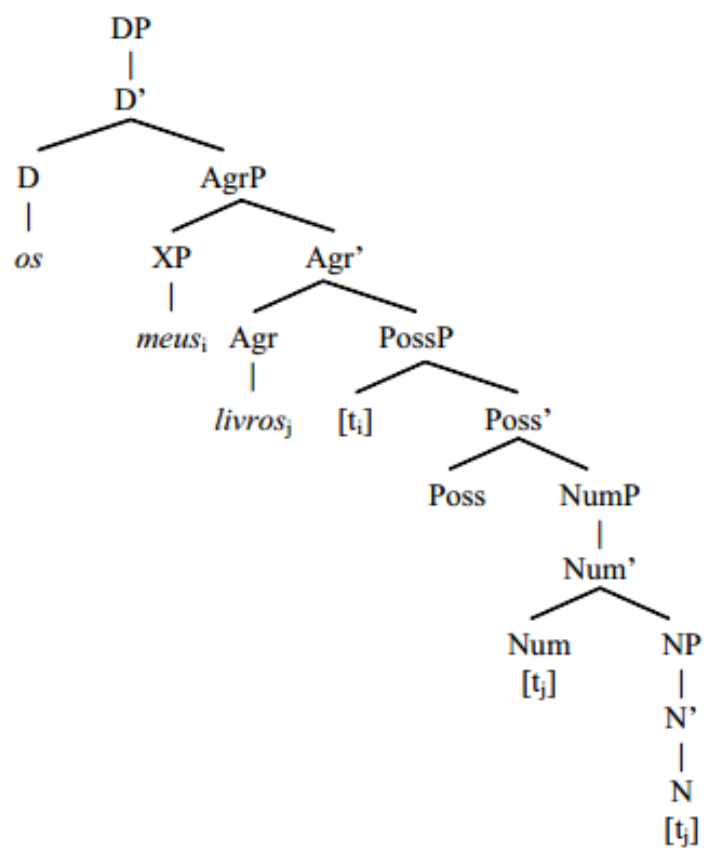

Figura 2.8: Estrutura da gramática não dominante do $\mathrm{PE}^{73}$

Brito afirma que na gramática não dominante os possessivos não são caracterizados com o traço [+definido], podendo ocorrer com indefinidos. Neste caso, são XPs e a motivação para o seu movimento decorre da atração pelo traço Pessoa em AgrP e Número em NumP. Desta forma, são distintos dos determinantes, identificando-se como adjetivos pronominais.

Por fim, quanto à gramática dominante, Brito argumenta que a mesma parece ter as propriedades da gramática dialetal por exigir a adjacência entre artigo e possessivo e por ter uma interpretação definida. Neste aspecto Brito acompanha Miguel (2002a), Castro (2006), e também Floripi (2008), uma vez que tais autoras reconhecem que a restrição aos contextos de definitude e a adjacência estrita entre possessivo e artigo estariam evidenciando uma reanálise categorial dos possessivos pré-nominais como núcleos em D. No entanto, Brito se distancia de Castro (2006) em relação aos testes que a autora apresenta sobre focalização e coordenação dos possessivos pré-nominais. Para Brito, tais testes não evidenciariam o

\footnotetext{
${ }^{73}$ Brito (2007:45), figura 68.
} 
estatuto dos possessivos como núcleos, mas sim como projeções máximas, configurando uma propriedade da gramática não dominante. A questão é então saber se os possessivos prénominais da gramática dominante estariam ou não em adjunção a $\mathrm{D}$, como proposto para a gramática dialetal, e também por Castro (2006) e Floripi (2008) para a gramática dominante, ou se ainda são adjetivos, na posição de Spec de uma categoria funcional. Brito conclui com a seguinte hipótese: a gramática dominante não é uma gramática homogênea. Ao contrário, ela é uma mistura de propriedades das outras duas gramáticas, a dialetal e a não dominante. No primeiro caso, o possessivo codifica [+def], mas é ainda adjetivo, ocupando a posição de SpecAgrP, embora tonando-se D gradualmente. No segundo caso os possessivos são APs e ocupam SpecAgrP, uma posição distinta daquela dos artigos definidos.

Concluindo este capítulo podemos afirma que, praticamente em todos os artigos resenhados constatamos que os autores se preocuparam em discutir o percurso diacrônico do artigo definido nos contextos de possessivos pré-nominais na história do português. Tal percurso é também bastante relevante porque retrata os rumos distintos tomados pelo PE e PB ao longo do tempo. Enquanto o artigo definido acompanha os sintagmas nominais com pronome possessivo no $\mathrm{PE}$, o mesmo é sistematicamente omitido no português antigo do século XIII. No PB, porém, a variação presença vs. ausência de artigo diante dos possessivos se mantém estável. Como caracterizar a mudança linguística que se manifesta nas duas variedades do português? Destacamos em nossas leituras algumas questões que foram tratadas particularmente por Floripi (2008), Castro (2006), Rinke (2009) e Brito (2007):

1) A questão da natureza categorial do possessivo: como determinante, ou como adjetivo;

2) A questão da natureza semântica do artigo definido: como elemento portador da definitude ou vazio semanticamente nos contextos possessivos;

3) A questão da natureza da mudança -o que teria mudado: o sistema dos possessivos ou o papel do artigo definido,- na perspectiva da teoria dos princípios e parâmetros.

4) A questão da natureza dos pronomes possessivos pré-nominais como formas fracas ou como clíticos.

Como vimos igualmente, a forma como foi entendido o fenômeno em estudo e as causas que levaram a uma mudança diacrônica na história das duas variedades do português, 
embora tenham apresentado pontos em comum, foram divergentes em outras respostas dadas às questões acima formuladas. 


\section{PROPOSTA DE ANÁLISE PARA O DP POSSESSIVO NO PB}

Como dissemos na introdução, o objetivo desta dissertação é apresentar uma abordagem do conhecido fenômeno caracterizado como presença vs. ausência do artigo definido diante do possessivo pré-nominal no português brasileiro (PB). Entendemos que tal discussão seria mais abrangente se fosse emoldurada pela perspectiva comparativa com o português europeu (PE), uma vez que as duas variedades seguiram rumos distintos em seu desenvolvimento diacrônico. Além disso, nosso estudo apoia-se na teoria gerativista, aliada aos pressupostos metodológicos da teoria sociolinguística laboviana.

O capítulo está dividido em duas partes. Na primeira, pretendemos trazer ainda algumas considerações adicionais a respeito de propriedades semânticas, sintáticas e morfológicas dos artigos definidos em particular, a noção de definitude e a categoria D (eterminante). Também na primeira parte apresentamos a hipótese sobre a sintaxe e semântica dos Nomes Nus (Bare Nouns-BNs) no PB, tal como desenvolvida em Borik, Cyrino \& Espinal (2012) e Cyrino \& Espinal (2013/2014).

$\mathrm{Na}$ segunda parte discutimos os aspectos centrais da proposta de Torres Morais (inédito), a qual assumiremos para tratar da natureza dos possessivos e artigos no PB, e da estrutura funcional interna do DP possessivo. A proposta se baseia não apenas em hipóteses a respeito da sintaxe e semântica dos $\mathrm{BNs}$ no $\mathrm{PB}$, como também apresenta pontos em comum e discordantes com os autores mencionados no capítulo 2 a respeito da variação presença vs. ausência dos artigos diante dos possessivos.

\subsection{Os artigos definidos}

$\mathrm{Na}$ descrição gramatical, os denominados artigos definidos, o, $a$, os, as, têm sido objeto de intensa investigação, quer do ponto de vista morfossintático, quer do ponto de vista semântico, em diferentes perspectivas teóricas. Um dos pontos intrigantes decorre do fato de que nem todas as línguas possuem artigos, como é o caso do japonês, do chinês, do coreano, e de tantas outras de diferentes famílias linguísticas. Em particular, as línguas românicas se tornam especiais do ponto de vista diacrônico, quando se considera que o latim não tinha artigos. Assim, como se afirma consensualmente, os artigos definidos das românicas evoluíram dos demonstrativos latinos. 
Na perspectiva da gramática gerativa, os artigos são membros de uma categoria funcional denominada Determinante, a qual abrange outros itens, tais como demonstrativos, artigos indefinidos, quantificadores e, como mostraremos mais adiante, possessivos prénominais em algumas línguas. Do ponto de vista semântico, os artigos motivam discussões a respeito de uma noção muito complexa: a noção de definitude. Além disso, a literatura relevante que foi considerada nesta dissertação nos mostrou que os artigos definidos se revelaram igualmente complexos em termos sintáticos.

\subsubsection{A hipótese do DP universal}

Para os linguistas gerativistas, a distribuição dos determinantes levou a que fosse repensada a estrutura interna do sintagma nominal $(\mathrm{NP})^{74}$, dentro da formulação da Teoria XBarra. Em trabalhos hoje clássicos, Szabolcsi (1983), com base no húngaro, e Abney (1987), implementam a ideia, conhecida como a Hipótese $\mathrm{DP}^{75}$, segundo a qual as frases nominais consistem num NP que é complemento de um núcleo funcional, o núcleo $\mathrm{D}$, levando a um entendimento mais aprofundado da sintaxe interna da frase nominal (2). Com isso, fica descartada a hipótese anterior sobre a estrutura a ser assinalada a projeções de determinantes: a de que o DP é gerado dentro dos NPs, na sua posição de especificador (1):

\section{(1) $\left[\mathrm{NP} D\left[\mathrm{~N}^{\prime} \mathrm{N}\right]\right]$ \\ (2) $[\mathrm{DP}[\mathrm{D}$ ’ D NP]]}

O resultado disso é que o DP passa a ser uma categoria sintática cujo núcleo seleciona um NP. Da mesma forma, a ausência de artigos em certas línguas colocou um desafio adicional para uma possível formulação paramétrica, envolvendo línguas com e sem artigos. Nas línguas com artigos, parece consensual o fato de que os argumentos seriam DPs. Mas, e nas línguas sem artigos? Que estrutura seria atribuída às expressões nominais? NPs ou DPs com D [+def] sem realização lexical?

Como já mencionado no capítulo 2, Longobardi refina e universaliza a proposta dos autores acima mencionados, formulando a Hipótese do DP Universal (Universal DP

\footnotetext{
${ }_{74}^{74}$ NP como sigla de Nominal Phrase.

${ }^{75}$ DP como sigla de Determiner Phrase.
} 
Hypothesis-UDPH), com base no italiano, língua na qual os NPs com e sem artigos comportam-se de forma distinta, nos seguintes termos:

$A$ "nominal expression" is an argument only if it is introduced by a category $D$. DP can be an argument, NP cannot.

(Longobardi 1994: 628).

A afirmação relevante de Longobardi para o italiano é a seguinte: um núcleo singular contável não pode ocorrer em nenhuma das posições canônicas de argumentos, por exemplo, sujeito (3a), objeto direto (3b), objeto preposicionado (3c), sujeito invertido de predicados ergativos ou inergativos (3d), sem ser introduzido por um determinante lexical, na maioria das vezes, um artigo definido ou indefinido, um quantificador ou demonstrativo: ${ }^{76}$

(3) a. *(Un/Il) grande amico di Maria mi ha telefonato.

b. *Ho incontrato (un il) grande amico di Maria ieri.

c. Ho parlato con * (un/il) grande amico di Maria iere.

d. Ha telefonato/ É venuto *(un/il) grande amico di Maria.

\subsubsection{Os artigos definidos e a noção de definitude}

Outro ponto que se torna relevante para entendermos a hipótese do DP tem a ver com a relação entre os artigos e a noção semântica de definitude. Tal relação tem levantado debates acalorados. No âmago da vasta literatura sobre o assunto, destacamos um ponto consensual: uma das funções mais proeminentes do artigo definido é a de codificar a definitude. No entanto, como caracterizar a noção? Para o nosso estudo sobre artigos e possessivos no PB, adotaremos a proposta de von Heusinger (2011), nos seguintes termos:

The concept of definiteness in natural language is of special interest because it seems to be pragmatic in nature but it has semantic impact. The analysis of definite expressions exhibits some aspects of the fuzzy borderline between semantics and pragmatics and the interaction between the two areas

(von Heusinger 2011).

\footnotetext{
${ }^{76}$ Longobardi (2004:612), exemplos 6 a-d.
} 
Nesses termos o autor apresenta fundamentos empíricos e teóricos para justificar a teoria da saliência a qual, segundo ele, contempla o que a teoria da unicidade e a teoria da familiaridade têm de melhor, e se destaca como um novo conceito de definitude. Uma expressão definida, em seus diferentes usos, se refere ao elemento mais saliente em um dado conjunto. Nesta dissertação, como veremos, vamos assumir a definição pré-teórica de Heusinger, a saber: Uma expressão definida denota sem ambiguidade um único objeto, ou seja, o objeto pode ser identificado como o único que é denotado pela expressão.

Podemos dizer ainda que a posição D pode estar associada a diversas propriedades, dependendo das diferentes perspectivas: (i) D é o local da noção semântico-pragmática da definitude; (ii) D é posição do artigo definido; (iii) DP é a projeção estendida do nome, que torna um nome num argumento sintático, ancorando-o no contexto extralinguístico. Portanto, não se tem ainda uma clara ideia que distinga o conceito $\mathrm{D}$ ou como posição sintática, ou como categoria sintática do artigo definido que o realiza em muitas línguas. Há uma ligação entre o artigo e D, o que torna difícil dizer se as propriedades mencionadas são propriedades inerentes a $\mathrm{D}$, como um posição ou categoria, ou do próprio artigo. (cf. Alexiadou \& al (2007) e Ghomeshi (2009)).

\subsubsection{O parâmetro semântico de Cherchia (1998)}

No entanto, embora a hipótese do DP tenha tido grande repercussão, a literatura relevante que consultamos mostra que a UDPH é desafiada pelo clássico trabalho de Chierchia (1998), no qual é proposta uma distinção paramétrica entre as línguas, com base na natureza semântica dos nominais. O autor formula o Parâmetro do Mapeamento Nominal (Nominal Mapping Parameter (NMP), propondo a existência de dois tipos de línguas: (i) línguas nas quais os nominais são $[-\arg ,+$ pred], e (ii) línguas nas quais os nominais são [+arg,+pred].

Tal parâmetro prediz que nas línguas do primeiro tipo, como é o caso das línguas românicas, os NPs nus, ou seja, NPs sem artigo (Bare Nouns- BNs), não poderão ocorrer em posição canônica de argumento, estando sua distribuição condicionada aos contextos em que o NP recebe uma interpretação predicativa. Nas línguas do segundo tipo, como as eslavas, que não têm artigos, e as germânicas, os BNs podem ocorrer em posição de sujeito e objetos. $\mathrm{O}$ inglês seria uma língua [+arg, +pred], por apresentar BNs argumentais em determinados 
contextos, embora tenha artigos. Ao contrário, como dissemos, as línguas [-arg, +pred] requerem um tipo de determinante para que uma expressão nominal possa ser licenciada como argumento sintático e semântico.

\subsubsection{Uma proposta para os BNs no PB}

Nesse ponto cabe uma pergunta: como ficaria o PB diante da UDPH e do NMP? Sabemos que o PB tem constituído um desafio para o NMP, como mostrado em Schmitt \& Munn (1999), Müller (2002) e trabalhos que se seguiram. Neles, os autores apresentam fatos empíricos de que os BNs no PB podem ocorrer na posição argumental de sujeito, objeto, e nas posições de predicado, ao contrário de línguas como o espanhol, o italiano, o português europeu, que apresentam importantes restrições de natureza sintática e semântica para o licenciamento dos BNs. O PB deveria, portanto, ser classificado como língua [- arg, +pred].

Recentemente Borik, Cyrino \& Espinal (2012) e Cyrino \& Espinal (2013/2014) trazem uma proposta muito interessante para tratar dos BNs no PB, assumindo que o PB faz parte das línguas [-arg, +pred], uma vez que sejam consideradas as previsões da UDPH, para incluir outra propriedade marcante, a saber, a de que o PB tem artigo definido nulo, fato este já reconhecido na literatura (cf. SCHMITT \& MUNN (1999), SCHMITT \& MUNN (2002), MUNN \& SCHMITT (2005)).

As autoras destacam as seguintes propriedades que individualizam o PB de outras línguas românica, no que se refere à natureza da expressão nominal:

(i) A aparente opcionalidade do determinante;

(ii) A realização variada de número no domínio nominal;

(iii) A ocorrência de BNs em todas as posições argumentais com significados variados dependendo do tipo de predicado no qual ocorrem.

Com base nessas propriedades, as autoras formulam duas hipóteses de trabalho:

HI1: Na posição de argumentos, BNs são DPs com um determinante nulo e projeção de Número (Num P).

H2: Número é morfossintaticamente valorado e interpretado em $\mathrm{D}$, mesmo quando o determinante é nulo. 
A H1 é uma clara adesão à HDPH, proposta em Longobardi (1994). Adicionando ainda a categoria NumP, as autoras assumem que (4) representa a estrutura sintática em para os argumentos nominais em todas as línguas

(4) [DP D [NumP Num [NP N ]]]

Vale notar, porém, que enquanto a estrutura universal do DP para argumentos nominais com artigos realizados lexicalmente não é contestada na literatura, o caso do PB cria um situação intrigante, uma vez que permite expressões nominais definidas, tanto com artigos realizados lexicalmente, quanto com artigos nulos fonologicamente, nas mesma posições argumentais. A partir dos fatos do $\mathrm{PB}$, as autoras assumem que a estrutura em (3) está disponível em todas as línguas, mesmo as que não têm artigos, como o russo, ou que tenham artigos, mas podem deixá-los omitidos, como é o caso do PB.

Os exemplos abaixo ilustram contextos em que os BNs podem ocorrer, em diferentes posições: sujeito (5a), objeto direto e indireto $(5 \mathrm{c})$ e predicado $(5 \mathrm{~b}){ }^{77}$ Como observamos acima, essa distribuição "permissiva" e uma interpretação particular dos BNs torna o PB bastante original.

(5) a. Criança lê revistinha.

b. João é médico.

c. Coreano vende roupa pra brasileiro.

Em (5a) o BN tem uma intepretação genérica de plural e criança se refere à soma máxima dos indivíduos do tipo criança, como em As crianças lêem revistinha. Da mesma forma a expressão nominal objeto em (5a) pode ter duas leituras: uma definida e outra indefinida, quer singular ou plural, dependendo da informação contextual disponível: $a(s)$ revistinhas e uma(s) revistinhas. Cyrino \& Espinal (2014) afirmam, porém, que os dados em (5a-c) não contradizem o Parâmetro do Mapeamento Nominal, formulado em Chierchia (1998), segundo o qual as línguas românicas têm nomes [-arg,+pred], de modo que os BNs só poderiam ocorrer em posição de predicado. Embora o PB permita BNs em posição de argumentos, pela hipótese assumida pelas autoras, tais BNs são DPs, com D nulo

\footnotetext{
${ }^{77}$ Munn and Schmitt (2005:823), exemplo 1b; 829, exemplo 19c, exemplo 3c tomado de Müller (2004:87), exemplo 50 apud CYRINO \& ESPINAL (2014:4), exemplos 3a-c no original.
} 
fonologicamente.

Assim, nos exemplos acima, apenas (5b) mostra um BN real, ou seja, aqui não temos um argumento, mas um NP na posição predicativa.

BNs no PB, portanto, podem ser definidos, uma vez que a gramática da língua permite descrições definidas com ou sem artigos explícitos, especificadas por Número. As autoras propõem um teste fundamental para confirmar o estatuto definido dos $\mathrm{BNs}$, com base na distribuição do pronome ele, o qual, impõe restrições fortes em relação a seu antecedente. De fato, no $\mathrm{PB}$, o pronome ele pode se referir apenas a expressões que denotam entidades, ou seja, seu antecedente tem que ser uma expressão definida. Vejamos os exemplo em (6a -b). ${ }^{78}$

(6) a. Eu limpei o banheiro ontem. Deixei ele bem brilhante. b. Eu limpei banheiro ontem. Deixei ele bem brilhante.

Em outros termos, os exemplos em (6a-b) evidenciam que as expressões banheiro e $o$ banheiro correspondem a estruturas DPs, uma vez que somente os DPs, mas não os NPs, são argumentos sintáticos canônicos, por terem a mesma distribuição. Além disso, o relacionamento discursivo com o pronome ele compatível unicamente com um antecedente DP é o mesmo queira o antecedente seja um DP ou um BN.

Outro exemplo ilustrativo se refere às condições de controle de PRO e ligação anafórica nos exemplos em (7a-b). O sujeito e objeto do verbo transitivo contratar, pode controlar o sujeito da subordinada e servir de antecedente para o pronome reflexivo. Como se sabe, o controlador de PRO e antecedente do anafórico deve ser um DP. Portanto, a expressão nominal empregada em (7a), é um DP com artigo definido nulo e não um NP (BN). ${ }^{79}$

(7) a. A Maria $a_{\mathrm{i}}$ contratou empregada $\mathrm{j}_{\mathrm{j}}$ ara $\mathrm{PRO}_{\mathrm{i}} / \mathrm{j} s e_{\mathrm{i}} / \mathrm{j}$ vestir de odalisca no carnaval.

b. A Maria $_{i}$ contratou uma empregada $a_{j}$ para $\mathrm{PRO}_{\mathrm{i}} / \mathrm{j} s e_{\mathrm{i}} / \mathrm{j}$ vestir de odalisca no carnaval.

Cyrino \& Espinal (2013/2014) assumem ainda que se uma língua por "default" tem uma estrutura como (2), pode possuir estruturas "menores" como as que estão listadas abaixo. Todas elas estariam disponíveis no PB.

\footnotetext{
${ }^{78}$ Cyrino \& Espinal 2013:3, exemplos 5a-b.

${ }^{79}$ Borik, Cyrino \& Espinal 2012:4, exemplos 6a-b.
} 
(8) a. [NP N ]
b. [DP D [NP N ]]
c. [NumP Num [NP N ]]

No que se segue, comentaremos apenas as estruturas em (8a) e (8b), por serem as que nos interessam mais de perto.

Segundo as autoras, a estrutura [NP N] em (8a) é a estrutura do BN real. No PB, os verdadeiros BNs são NPs e estão restritos à posição de objeto do verbo TER. Nesse contexto, os BNs estão associados à denotação do tipo propriedade, não do tipo entidade, e apresentam neutralidade de número. Uma evidência sintática para o estatuto de BN do objeto é o fato de que o mesmo não pode ser controlador de PRO e antecedente de anafórico: ${ }^{80}$

(9) a. A Maria $_{i}$ tem empregada para $\mathrm{PRO}_{\mathrm{i}} / *_{\mathrm{j}} s e_{\mathrm{i}} /{ }_{\mathrm{j}}$ vestir de odalisca no carnaval.

Por fim, o caso da estrutura em (8b) é bastante relevante, porque é um DP, mas não projeta Número. Cyrino \& Espinal (2013/2014) propõem que se trata da estrutura que está associada a argumentos com o significado de espécie definida. Espécies definidas evidenciam a presença da projeção $\mathrm{D}$ e a ausência de número em todas as línguas. O exemplo abaixo ilustra um predicado genérico, no qual o sujeito se refere a espécie definida. ${ }^{81}$

(10) Panda está em extinção. Ele é o símbolo oficial do WWF.

Observe-se que o sujeito panda pode ser o antecedente de pronome forte ele, evidenciando o seu estatuto como argumento. Observe-se ainda que o pronome não pode estar no plural, uma vez que o sujeito com intepretação de espécie nomeia uma classe de objetos individuais que compartilham a propriedade do $\mathrm{N}$ panda. $\mathrm{E}$, por ser nome de uma espécie, não se refere à soma máxima dos indivíduos. Espécies definidas licenciam, porém, pronomes reflexivos. $\mathrm{O}$ antecedente do pronome reflexivo deve ser referencial. ${ }^{82}$

(11) Dodô desapareceu da superfície da terra porque ele não pôde se proteger de ataques.

\footnotetext{
${ }^{80}$ Borik, Cyrino \& Espinal 2012: 6, exemplo 10a.

${ }^{81}$ Borik, Cyrino \& Espinal 2012: 7, exemplo 14.

${ }^{82}$ Borik, Cyrino \& Espinal 2012: 8, exemplo 16.
} 
O terceiro argumento usado pelas autoras é o de que, no PB, espécies definidas podem ser expressa por meio de um DP com artigo expresso. Vejamos o paradigma em (12a-b): ${ }^{83}$

(12) a. O panda logo estará extinto.

b. Panda logo estará extinto.

Portanto expressões que denotam espécies podem ser realizados como DPs no PB quer o determinante seja nulo ou lexical.

Lembramos que a expressão que se refere a espécie é sintaticamente e semanticamente incompatível com Número, como mostra o exemplo em (13): ${ }^{84}$

(13) *Dois dodôs desapareceram no século XVII.

\subsubsection{Concordância variável de número no interior da frase nominal}

Outro ponto importante para se entender os fatos dos BNs no PB é o que se relaciona ao conhecido fenômeno da variação na concordância de número no DP. Vejamos os exemplos abaixo: ${ }^{85}$

(14) a. Os brasileiro é trabalhador.

b. Os brasileiro são trabalhadores.

c. *O brasileiros é trabalhadores.

Tais exemplos são relevantes por mostrarem que no PB, assim como nas outras línguas românicas, o lugar da expressão de número e definitude é D. Daí a agramamticalidade de (14c). No PB, porém, a expressão da concordância nominal e verbal entre os elementos nominais e sentenciais mostra variação de natureza coloquial/formal.

A variedade mais conservadora, ao contrário da coloquial, tem a pluralidade expressa em todos os constituintes do DP (cf. SCHERRE, 1988, 1994, SCHERRE and NARO, 1998,

\footnotetext{
${ }^{83}$ Borik, Cyrino \& Espinal 2012: 8, exemplo 16.

${ }^{84}$ Borik, Cyrino \& Espinal 2012: 8, exemplo 19.

${ }^{85}$ Cyrino \& Espinal (2014:2), exemplos 2a-c.
} 
entre outros). Dessa forma, um BN no singular pode ser plural, uma vez que o artigo nulo esteja instanciando as marcas de plural. Tais fatos, evidenciam a hipótese de que, no PB, Número é morfossintatiacmente valorado e interpretado em $\mathrm{D}$, mesmo quando o determinante é nulo.

Por fim, o conjunto de exemplos em (15), constituem novas evidências para as hipóteses assumidas para o PB, em relação à aparente opcionalidade dos artigos e a realização variável de número: ${ }^{86}$

(15) a. O brasileiro é trabalhador.

b. Os brasileiros são trabalhadores

c. Brasileiro é trabalhador.

d. Brasileiros são trabalhadores.

Olhando para o conjunto de sentenças acima, é possível pensar que o determinante não tem nenhum efeito no significado de uma expressão nominal na posição de sujeito, em sentenças genéricas. As autoras afirmam, porém, que não há opcionalidade real na realização do artigo definido. No PB, como nas outras línguas românicas, a categoria D é requerida para os argumentos. Assim, o que parece ser um BN, como no exemplo (15c) é um DP com determinante nulo.

Além disso, devido à marcação de número apenas no artigo no $\mathrm{PB}$, os $\mathrm{BNs}$ podem ter uma interpretação ambígua com duas estruturas distintas. Em (15a e 15c) as expressões nominais o brasileiro/brasileiro são DPs com artigo definido que podem projetar duas estruturas: uma sem projeção de Número (NumP), que força a intepretação de espécie definida, ou seja, de classe, satisfazendo uma propriedade denotada por N, a espécie brasileiro (15a) e a outra em (15c), que projeta NumP, marcado em D (os brasileiro), o que força a interpretação de soma máxima de todos os elementos do conjunto denotado pelo Nome, ou seja, aos indivíduos da classe dos brasileiros.

Assim, no PB, argumentos canônicos permitem a omissão do artigo. E permitem que número seja especificado foneticamente somente no artigo. Seguindo Longobardi (1999, 2000), Cyrino \& Espinal (2014) postulam que um determinante quer realizado ou ausente é um criador de argumento e portador da definitude. Sem a hipótese de D nulo seria difícil

\footnotetext{
${ }^{86}$ Müller (2002:280), exemplos 1, 2, 4 e 5 apud CYRINO \& ESPINAL (2014:2), exemplos 1a-d. no original.
} 
explicar o licenciamento da anáfora do tipo entidade ele. D também seria o ativador da referência discursiva. Ainda com base em Bouchard (2002) e Dobrovie-Sorin (2012), as autoras afirmam que Número é essencial para extensionalizar a propriedade denotada pelo Nome.

Como dissemos, os fatos relacionados à realização de número apontam para o papel crucial de D em tornar possível a referência. Assumimos daqui para frente que, o PB codifica a especificação morfossintática de Número e interpretabilidade em D.

Finalmente, o exemplo (16), mencionado em nota de rodapé por Cyrino \& Espinal (2014), recebeu um destaque especial em Torres Morais (inédito), como veremos, por ser crucial para a sua hipótese a respeito dos DPs possessivos: ${ }^{87} \mathrm{O}$ exemplo ilustra o fato de que a referência única do BN pós-verbal na posição de objeto, revela que o termo aliança pode se referir no discurso unicamente ao objeto antecedente a minha aliança, e ao DP seu anel de casamento.

(16) “Perdi a minha aliança !”, gritou Didi. Às vésperas da Copa do Mundo de1958, o meio-campista parou o treino da seleção canarinho para procurar seu anel de casamento .[...] E nada de encontrar aliança .

Segundo as autoras

BNs can be definite specific in BrP: that is, it is possible for a $\mathrm{BN}$ to have a fixed reference and, therefore, to refer back to an entity either already introduced in the discourse or part of the common ground, without the support of an overt determiner.

Cyrino \& Espinal (2014:13)

\subsubsection{A estrutura interna do DP}

Como acima discutido, Cyrino \& Espinal (2013/2014) assumem que a categoria Número é requerida sintaticamente e semanticamente no domínio do DP (cf. RITTER, 1991). As autoras propõem a estrutura em (8a), para as sentenças (15a-d), ou seja, corresponde a (15b) os brasileiros, (15c) (em uma das intepretações), e (15d) brasileiros. Observe-se que em (16b) temos a operação de movimento do Nome, gerado dentro da frase nominal (NP) para a camada $n \mathrm{P}$, onde tem valorado seu traço não interpretado de Número.

\footnotetext{
${ }^{87}$ Cyrino \& Espinal (2014:12), nota de rodapé 10, exemplos 2a-c no original, extraídos da versão online da revista Almanaque Brasil.
} 


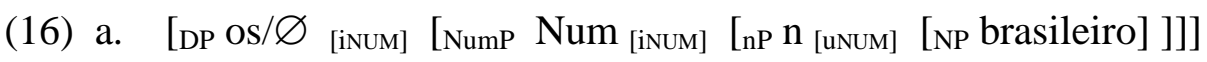

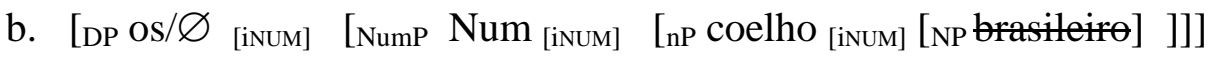

As autoras propõem que a concordância de Número é realizada através da operação Agree (Concordância), envolvendo elementos que carregam semanticamente traço interpretável de Número [iNUM] e elementos que portam traços não interpretáveis de Número [uNUM]. A relação Agree parece se efetivar numa direção inversa, contrariamente a Chosmky (2001), operando de cima para baixo, com os traços [iNUM] c-comandando os traços [uNUM) (cf. BIBERAUER \& ROBERTS 2011; BIBERAUER \& ZEIJLSTRA 2012). $\mathrm{Na}$ estrutura proposta, somente n é especificado [uNUM]), O traço [iNUM], um traço sintático inerente de D e Num, é compartilhado entre D e Num, mesmo quando D é nulo.

As autoras concluem que a abordagem da variação na realização de número, dentro do domínio nominal, resulta das seguintes postulações: Número, no PB, é morfossintaticamente especificado e interpretável em D, e valorado por meio de uma operação de Agree inverso (envolvendo elementos que carregam traços de Número interpretável e não interpretável). A concordância morfofonológica de Número, porém, é pós- sintática.

As estruturas DPs sem a projeção de Número são unicamente associadas com a intepretação de espécie definida, revelando que, dependendo da posição do tipo de predicado e tipo de sentença o que se parece com BNs em BP são DPs definidos.

Portanto em BP, BNs podem ser expressões definidas (individualizadas, referenciais). Por fim, as autoras concluem que a análise dá conta do fato de que o mesmo grupo de falantes nativos pode alternar a escolha de um determinante nulo ou realizado. Há apenas uma gramática que especifica Num em D, uma vez que concordância entre D e N é pós-sintática. A análise é apropriada para a variedade formal e informal do PB. 


\subsection{DPs possessivos no $\mathrm{PB}$}

No artigo intitulado "Artigos definidos e possessivos: uma visão microparamétrica" Torres Morais (inédito) ${ }^{88}$, observa que há uma literatura muito interessante sobre o PB no quadro da teoria gerativa, lidando com aspectos da sintaxe e semântica dos possessivos, tanto nas construções de possuidor externo, quanto nas construções de possuidor interno. A autora chama a atenção para o fato de que os pesquisadores estão preocupados em propor uma estrutura do DP para as expressões definidas e possessivas, considerando a variação na expressão da concordância de número no interior do DP, a variação na presença vs. ausência do artigo definido diante dos possessivos pré-nominais, os possessivos nulos e outros aspectos (cf. KATO (1985); MENUZZI (1996); CERQUEIRA (1996); FLORIPI \& NUNES (2009); RODRIGUES (2010).

Além disso, é bastante produtiva a literatura gerativista que compara o PB com o PE, como vimos no capítulo 2 desta dissertação (cf. MIGUEL 2002; COSTA \& CASTRO 2003; MAGALHÃES 2004; CASTRO 2006; COSTA \& FIGUEIREDO SILVA 2006; BRITO 2007; RINKE 2010, e referencias neles citadas).

A autora tem dois objetivos principais, fortemente inspirados na teoria dos $\mathrm{BNs}$, como elaborada por Borik, Cyrino \& Espinal (2012), e Cyrino \& Espinal (2013/2014), resenhados na seção anterior. São eles:

1) Discutir uma estrutura a ser atribuída aos DP possessivos no PB, considerando as propriedades sintáticas e semânticas dos BNs definidos, em posição argumental;

2) Mostrar que as diferenças entre o PE e PB relacionadas à presença vs. ausência do artigo definido diante do possessivo decorre de duas propriedades gramaticais presentes no PB, mas ausentes no PE:

(i) o PB permite um D definido nulo especificado por Número;

(ii) a presença do possessivo pré-nominal no interior do DP pode mudar a dinâmica na qual os traços de Número são morfossintaticamente valorados e interpretados.

\footnotetext{
88 Torres Morais (inédito). Artigos definidos e possessivos: uma visão microparamétrica. Baseada na comunicação apresentada em Romania Nova VII in commemoration of Mary Kato's 80th Birthday. BUENOS AIRES - November 26 to 28 - 2014.
} 
Em particular, Torres Morais retoma os fatos discutidos a respeito dos BNs argumentais do PB e postula a hipótese de que são os mesmos que identificam os DPs possessivos nas duas propriedades abaixo mencionadas.

Propriedade A: Presença de artigos definidos nulos nos DPs possessivos, em variação com a sua realização lexical. ${ }^{89}$

(17) a. A minha bicicleta está quebrada. (PE-PB)

b. Minha bicicleta está quebrada. (PB-*PE)

Propriedade B: Variação sistemática de concordância entre os elementos que integram o DP possessivo (cf. SCHERRE 1988, 1994; SCHERRE \& NARO 1998; COSTA \& FIGUEIREDO SILVA 2006, entre outros). Como a autora lembra, os estudiosos têm notado que a gramática formal mostra a pluralidade expressa em cada constituinte dentro do DP definido, enquanto a gramática coloquial produz sequências bem formadas, nas quais a especificação de traços de Número pode estar apenas no determinante/artigo. Entretanto, dada a sequência $\mathrm{D}+\mathrm{Poss}+\mathrm{N}$ se somente um dos constituintes pré-nominais porta a especificação de traços de Número, este constituinte será o possessivo e não o determinante. Vejamos o paradigma em (18): ${ }^{90}$

(18) a. A minhas bicicleta estão quebradas.

b. Minhas bicicleta estão quebradas.

c. *As minha bicicleta estão quebradas.

\subsubsection{Uma proposta de análise para a estrutura do DP possessivo no PB}

Retomemos as duas hipóteses assumidas por Cyrino \& Espinal (2013/2014) para o estudo dos BNs no PB:

H1: Na posição de argumentos, BNs são DPs com um determinante nulo e projeção de Número (Num P).

\footnotetext{
${ }^{89} \mathrm{Cf}$. os estudos resenhados no capítulo 2.

${ }^{90}$ Cf. capítulo 2 onde esse padrão foi discutido.
} 
H2: Número é morfossintaticamente valorado e interpretado em $\mathrm{D}$, mesmo quando o determinante é nulo.

A partir das duas hipóteses, Torres Morais propõe uma estrutura básica para o DP possessivo no PB. Como ela esclarece, porém, para tal tarefa é necessário considerar questões básicas, entre elas:

(i) A questão da natureza categorial do possessivo;

(ii) A questão da natureza semântica do artigo definido: como elemento portador da definitude ou vazio semanticamente nos contextos possessivos;

(iii) A questão do locus das mudanças que se observam na evolução do PB: o sistema dos definidos ou o sistema dos possessivos.

\subsubsection{A natureza categorial dos possessivos pré-nominais e dos artigos}

Com relação à distribuição dos possessivos a autora critica a rigidez das tipologias propostas em Schoorlemmer (1998) entre línguas do Tipo 1 (possessivo determinante) e línguas do Tipo 2 (possessivo adjetivo) e a divisão tripartite de Cardinalletti (1998) entre formas fortes e deficientes (possessivos fracos e clíticos), apoiando-se em autores como Ihsane (2000), Alexiadou (2004) e von Peterghem (2012), para propor que os paradigma dos possesivos são heterogêneos, entre as línguas e dentro de uma mesma língua. Com base em diferentes línguas românicas, pode-se distinguir os possessivos em três tipos: pronomes, adjetivos e determinantes. Para tanto, é importante reconhecer a natureza dual dos possessivos: sintaticamente ocorrem em posição adnominal (como modificadores ou especificadores); do ponto de vista semântico e referencial comportam-se como pronomes, uma vez que podem se referir a uma entidade, o possuidor, o qual pode ser identificado deiticamente ou anaforicamente.

Como Torres Morais ressalta, com base em van Peteghem (2012), o padrão de concordância no interior do DP possessivo mostra a sua natureza dupla. Assim, enquanto pronomes, os possessivos herdam seus traços de pessoa e número, do antecedente ou referente. Enquanto adjetivos, concordam em gênero e número com o núcleo (possuído).

No entanto todas as formas possessivas exibem concordância de pessoa e número com o possuidor. E número e gênero com o possuído. O padrão duplo se expressa de forma distinta na morfologia: com o possuidor a concordância é expressa pela raiz das formas possessivas, 
portanto lexicalmente, o que configura um acordo referencial, não concordância gramatical. Ao contrario a concordância com o nome é marcada por morfemas flexionais, ativada por relações gramaticais.

A autora assume ainda o padrão de gramaticalização proposto em von Peteghem (2012), no qual, através do desenvolvimento diacrônico, os possessivos passam por duas fases: formas fortes se tornam fracas em posição pré-nominal, usadas com outros determinantes, e as formas fracas tendem a ocupar a posição de determinante, sofrendo cliticização. O processo de gramaticalização está mais avançado no francês, uma vez que as formas possessivas não mais apresentam propriedades adjetivais. $\mathrm{O}$ menos avançado é o italiano onde os possessivos são ainda adjetivais. Torres Morais assume que este é o caso do PB, segundo ela evidenciado pelo fato de que o possessivo pré-nominal ocupa uma posição funcional distinta do determinante em $\mathrm{D}$, e apresenta a concordância adjetival com o núcleo do NP possuído.

O estatuto categorial dos possessivos como adjetivos em posição pré-verbal, leva a autora a propor que estrutura do DP possessivo implica a projeção de uma categoria funcional dentro do conjunto de projeções funcionais no domínio DP. A categoria, denominada FP pela autora, é semelhante à categoria PossP, proposta por Rinke (2010), projetada entre o DP e NumP. Assim, tanto no contexto dos nomes relacionais ou não relacionais, o possessivo é gerado no Spec, FP e recebe caso genitivo inerente do núcleo funcional que o introduz (cf. ZRIBI-HERTZ (2007); GUERÓN (2007)).

Portanto, podemos concluir que a proposta de Torres Morais, no que concerne ao estatuto categorial do possessivo pré-nominal no PB, vai contra a proposta de Castro (2006), a qual afirma que não há distinção categorial no sistema dos possessivos no PB e PE. Como vimos, a autora trata os possessivos nas duas variedades do português como núcleos, comportando-se diferentemente dos possessivos XPs, do tipo italiano.

Quanto à variação na presença vs. ausência do determinante no interior dos DPs possessivos, fica claro que Torres Morais não atribui a eles o estatuto de elementos expletivos, uma vez que a sua análise se baseia na sintaxe e semântica dos BNs, desenvolvida por Cyrino \& Espinal (2013/2014). Assim, a variação presença vs. ausência dos determinantes é apenas no nível pós-sintático, o mesmo ocorrendo com a variação na concordância dos traços de Número. Com isso, a estrutura do DP possessivo não se altera. No entanto, segundo a autora, a presença do possessivo altera a dinâmica na qual os traços de Número são morfossintaticamente interpretados, como ilustrado em (19a-b): 


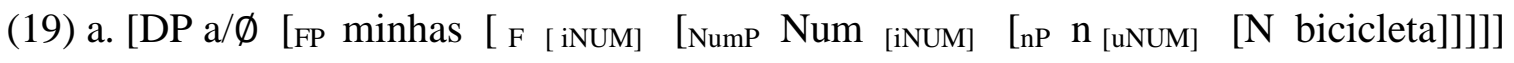
b.[DP a/ $\emptyset$ [FP minhas [ F [ iNUM] [NumP Num ${ }_{[i N U M]}$ [nP bicicleta $_{[\text {iNUM] }}[\mathrm{N}$ bicicleta $\left.\left.]\right]\right]$

Nessas estruturas temos as seguintes operações:

(20) a. O traço inerente $[i \mathrm{NUM}]$ é compartilhado entre Num e F, o núcleo do FP, que introduz o possessivo na posição de Spec, FP.

b) $\mathrm{O}$ traço $[u \mathrm{NUM}]$ de $n$ é valorado e o nome bicicleta é movido para $n$. A relação é sintática e determinada por c-comando;

c) $\mathrm{O}$ traço $[i \mathrm{NUM}]$ em F é realizado morfofonologicamente pelo possessivo pré-nominal, gerado em SpecFP;

d) A concordância morfofonológica de número no nome e no determinante é póssintática, não estando representada na estrutura.

Como acima comentamos, Torres Morais afirma que, embora os traços de Número [iNUM] em D, típicos dos DPs definidos tenham sido valorados em $\mathrm{F}$, isso não significa considerar que o artigo (nulo ou realizado), gerado em D, seja um expletivo, vazio semanticamente, de modo ficando o possessivo como o marcador de definitude e possessividade, como proposto por Castro (2006).

Com base nessas reflexões, a autora reformula a $\mathrm{H} 2$ para o $\mathrm{PB}$ nos seguintes termos:

(i) D é o local da definitude;

(ii) $\mathrm{O}$ determinante, nulo ou realizado, é obrigatório para expressar a definitude;

(iii) $\mathrm{Na}$ estrutura interna do DP possessivo, o traço $[i \mathrm{NUM}]$ é morfossintaticamente interpretado em F;

(iv) A categoria que porta a marca de Num é a primeira categoria funcional que merge após NumP.

Nas palavras da autora, reproduzidas abaixo, temos as suas conclusões:

I assumed the analysis of BNs in BP put forward by Cyrino \& Espinal (2014). I showed that it must be adapted to account for differences observed between EP and BP in the realm of the Possessive DP. I left implicit the idea that BP definite article is not a lexical or null expletive. In particular, its optionality is only apparent because BNs and possessive DPs, with null articles, are definite DPs. 


\subsubsection{Uma proposta para o DP possessivo no PE}

Nos estudos resenhados no Capítulo 2 desta dissertação, a maioria deles apresentou hipóteses para dar conta da natureza dos artigos definidos diante dos possessivos prénominais. Um dos aspectos mais intrigantes é de natureza histórica: o PE, mas não o PB, passa a exigir artigos obrigatoriamente realizados na presença do possessivo. Um ponto, porém, foi consensual entre os pesquisadores: os DPs possessivos são expressões definidas, estando o artigo e possessivo em adjacência estrita no domínio do DP. Não houve, porém, consenso quanto ao estatuto do artigo como elemento de conteúdo semântico, gramaticalizado para marcar a definitude/referencialidade, ou como expletivo, gerado em D, sem importe semântico.

Como vimos, a proposta de Torres Morais, comparando DPs possessivos e BNs no PB, contempla a hipótese de que os artigos no PB, lexicais ou nulos, são os portadores de definitude e pluralidade, ou seja, não são vazios semanticamente. Na presença dos possessivos, o traço de Número realizado em F, não altera natureza de $\mathrm{D}$ como portador da definitude. No entanto, embora a autora tenha assinalado as diferenças que caracterizam o PE e PB, ela não deixou muito claro qual seria o estatuto do determinante no PE, nem qual seria a natureza categorical do possessivo: como núcleo, gerado em $\mathrm{D}$, ou como XP, gerado em Spec,FP.

Para sanar essa lacuna, propomos a hipótese de que, no PE, a obrigatoriedade do artigo, atingindo os DPs possessivos e os contextos genéricos, leva a um uso expletivo do mesmo. Tal movimento ocasiona, por sua vez, uma recategorização do possessivo que se torna uma forma fraca, gerado em D, realizando nesta posição os traços de definitude e posse, como sugerido em Castro (2006). 


\section{METODOLOGIA E RESULTADOS QUANTITATIVOS}

Neste capítulo, o objetivo geral é apresentar resultados de nossa abordagem quantitativa referentes à variação na colocação dos artigos definidos em sintagmas nominais com formas possessivas de $3^{\mathrm{a}}$ pessoa, seu, sua, seus suas, em posição pré-nominal. Já no capítulo 2 dessa dissertação, demos destaque a resultados quantitativos obtidos em alguns trabalhos anteriores, dentre muitos outros hoje disponíveis na literatura sobre o assunto, pelo fato de adotarem uma perspectiva comparativa entre o português europeu (PE) e o português brasileiro (PB), e por buscarem traçar o percurso histórico de tal variação.

O capítulo está dividido em seções e subseções, em cuja seção 4.1 apresentamos o corpus jornalístico, na seção 4.2 a fonte documental e fatores linguísticos de análise, na seção 4.3 os resultados quantitativos quanto a presença versus ausência do determinante diante do possessivo e, partindo do condicionador período, o cruzamento com os fatores: tipos de sintagma (DP possessivo sem preposição e os diferentes tipos de preposição introdutoras de DPs possessivos - PP), a pessoa pronominal, tipos de verbos, função sintática do sintagma, tipos de posse do sintagma, tipos de texto e localidade do texto. Por último, apresentamos as considerações finais e relevantes sobre os resultados (seção 4.5).

\subsection{Apresentação do Corpus}

Como mencionado na introdução, selecionamos um corpus jornalístico composto de anúncios e cartas de leitores e redatores extraídos de jornais paulistas (capital e interior), contemplando a primeira e segunda metades do século XIX. Esse corpus jornalístico faz parte do acervo documental construído no âmbito do projeto temático de equipe Para a História do Português Paulista (PHPP), o qual, por sua vez, é um desdobramento de um projeto mais abrangente, denominado Para a História do Português Brasileiro (PHPB), ambos idealizados por Ataliba Teixeira de Castilho, com sede na Universidade de São Paulo (USP). ${ }^{91}$

Podemos dizer que vários temas articulam o PHPP, entre eles, os que se referem à investigação da comunidade linguística de São Paulo, a análise teórica dos fenômenos de mudança gramatical e à organização do Corpus Diacrônico do Português Paulista e seu tratamento empírico. Os temas acima mencionados articulam-se, por sua vez, nos seguintes

\footnotetext{
${ }^{91}$ cf. Castilho (2009) para uma detalhada reflexão sobre ambos os projetos históricos, os quais, segundo o autor, foram motivados pelos achados do Projeto Norma Urbana Culta (NURC) e do Projeto de Gramática do Português Falado (PGPF). Assim, há em comum o objetivo de indagar como se implantou e se desenvolveu a modalidade brasileira do português.
} 
objetivos: (i) Traçar a sócio história do português paulista, estudando a ocupação demográfica do território, a formação das variedades culta e popular, e a difusão da variedade popular em direção a Mato Grosso; (ii) Estudar a mudança gramatical da variedade paulista do português brasileiro, em diferentes perspectiva teóricas; (iii) Organizar e disponibilizar o Corpus Diacrônico do Português Paulista, de forma a estimular novas pesquisas sobre essa variedade.

Para cada objetivo contemplado no PHPP, alguns subprojetos foram organizados, ocupando-se cada um de sua área. A presente dissertação está inserida no subprojeto "Gramáticas paulistas na história do português brasileiro", que se individualiza pelo quadro teórico e pelos temas escolhidos. ${ }^{92}$

Os anúncios que coletamos foram publicados no livro E os preços eram commodos...: anúncios de jornais brasileiros século XIX, organizados por Guedes \& Berlinck (2000). O quadro 4.1 da página a seguir apresenta todos os jornais e anúncios disponíveis neste acervo.

\footnotetext{
${ }^{92}$ O primeiro objetivo do Subprojeto, coordenado pela Profa. Maria Aparecida Torres Morais, juntamente com outros colaboradores, é descrever e analisar fenômenos de variação e mudança sintáticas que revelem convergências e contrastes centre o Português Paulista e outras variedades do Português Brasileiro. Relacionado ao primeiro, o segundo objetivo visa a contribuir com a tarefa de formação de corpus representativo do Português Paulista. O Subprojeto propõe uma abordagem da mudança morfossintática com base em duas vertentes teóricas: a da teoria gerativa dos princípios e parâmetros $(\mathrm{P} \& \mathrm{P})$ e da teoria sociolinguística da variação e mudança. Os temas que foram selecionados envolvem o sistema pronominal (pronomes pessoais, possessivos, demonstrativos), categorias funcionais, fatos de concordância nominal e verbal, ordem das palavras, e outros.
} 


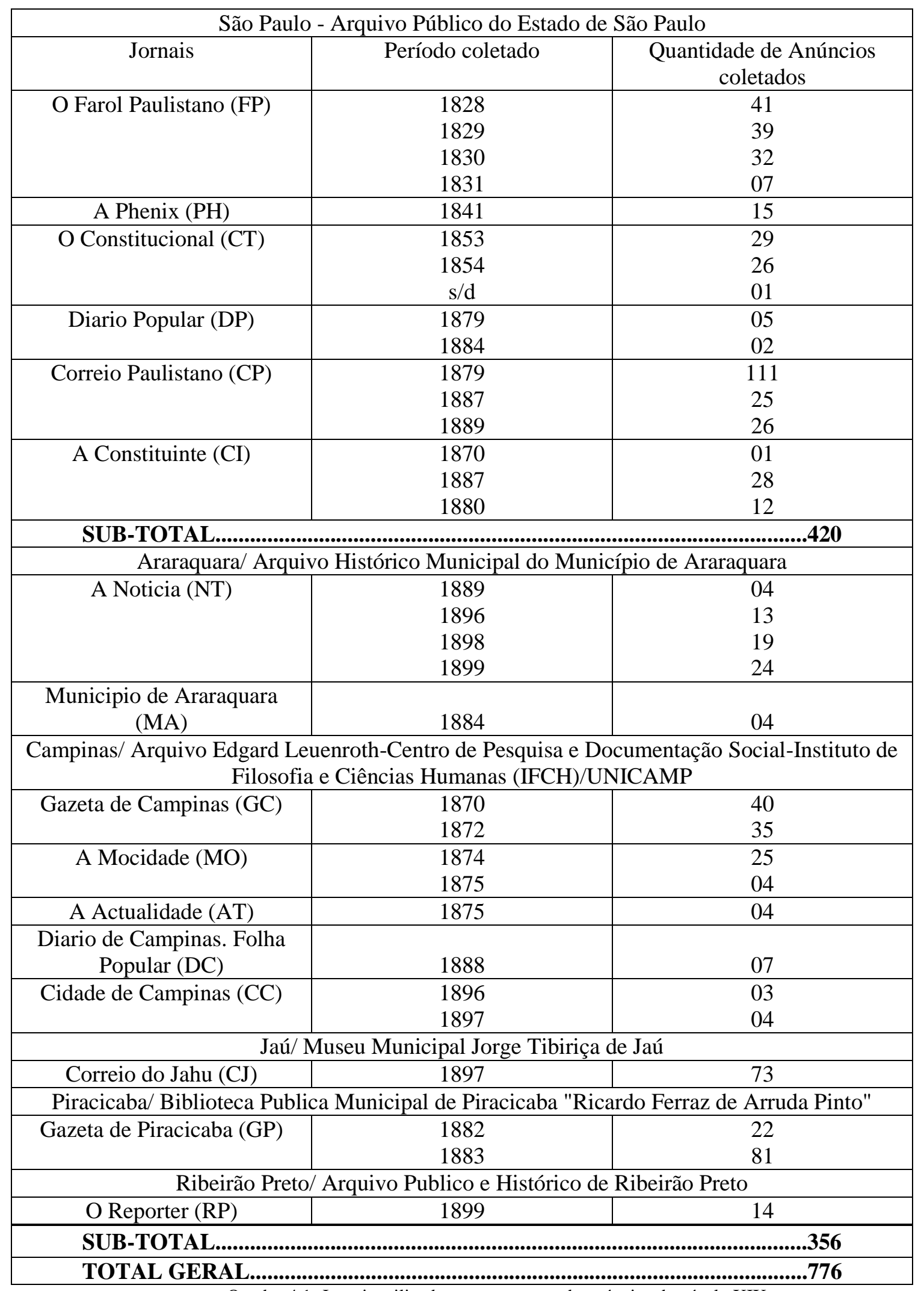


As cartas de leitores e redatores, por sua vez, foram retiradas do livro Críticas, queixumes e bajulações na Imprensa Brasileira do séc. XIX: cartas de leitores e cartas de redatores, organizados por Barbosa \& Lopes (2006). Os quadros 4.2 e 4.3 e apresentam a distribuição desse acervo:

\begin{tabular}{|c|c|c|}
\hline SÃO PAULO - SÃO PAULO & Cartas de Leitor $\mathrm{n}^{\mathrm{os}}$ & Cartas de Redator $\mathrm{n}^{\mathrm{os}}$ \\
\hline A Nação & ------ & 534-535; 537-543 \\
\hline A Noite & $\begin{array}{l}----- \\
\end{array}$ & $\begin{array}{l}536 ; 544-549 ; 559- \\
561\end{array}$ \\
\hline A OPINIÃO & ------ & 528 \\
\hline A PHENIX & $438-441$ & $\begin{array}{l}----- \\
\end{array}$ \\
\hline A Platéa & " ------ & 550-558; 562-566 \\
\hline A Província de S. Paulo & $512-513$ & - \\
\hline Aurora Paulistana & " ----- & $478-479$ \\
\hline Correio Paulistano & $442-447 ; 516-524$ & $\begin{array}{c}481-505 ; 506-507 ; \\
529-532 \\
\end{array}$ \\
\hline Diario de São Paulo & $510-511 ; 514$ & ------ \\
\hline " DIÁRIO LIBERAL & $\begin{array}{c}----- \\
\end{array}$ & 526 \\
\hline ESTADO DE SÃO PAULO & $\begin{array}{ll}------ \\
\end{array}$ & 533 \\
\hline $\begin{array}{l}\text { Farol Paulistano } \\
\end{array}$ & 389-394 & $395-437$ \\
\hline O Confilador Paulistano & $\begin{array}{ll}----- \\
\end{array}$ & 480 \\
\hline O Holophote & $\begin{array}{ll}----- \\
\end{array}$ & 527 \\
\hline O Publicador Paulistano & ------ & 508-509 \\
\hline \multicolumn{3}{|l|}{ SANTOS - SÃO PAULO } \\
\hline Cidade de Santos & $524-525$ & ------ \\
\hline
\end{tabular}

Quadro 4.2: Jornais utilizados para o corpus de cartas de leitores e redatores do século XIX.

\begin{tabular}{|c|c||c|}
\hline \multicolumn{3}{|c|}{ São Paulo } \\
\hline \hline Fases & Leitor & Redator \\
\hline \hline Fase 1 & $389-394$ & $395-437$ \\
$(\mathbf{1 8 0 8 - 1 8 4 0 )}$ & 06 cartas & 43 cartas \\
\hline \hline Fase 2 & $438-477$ & $478-509$ \\
$(\mathbf{1 8 4 1 - 1 8 7 0 )}$ & 40 cartas & 33 cartas \\
\hline \hline Fase 3 & $510-525$ & $526-566$ \\
$(\mathbf{1 8 7 1 - 1 9 0 0 )}$ & 16 cartas & 41 cartas \\
\hline
\end{tabular}

Quadro 4.3: Distribuição das cartas de leitores e redatores paulistas ao longo do século XIX.

Para a nossa abordagem quantitativa, optamos por compor uma amostra representativa do material disponibilizado, a partir da contagem de 5.000 palavras para cada gênero textual (carta de leitores, redatores e anúncios) e período (primeira metade do século XIX e segunda metade do século XIX). 
No quadro 4.4 a seguir, nomeamos os jornais da Capital consultados e a quantidade dos anúncios referentes às duas metades do século XIX. Para o interior, apenas anúncios da segunda metade do século XIX foram encontrados no corpus, como mostra o quadro 4.5. No mesmo quadro expomos os jornais consultados.

\begin{tabular}{|c||c|c|}
\hline \multicolumn{3}{|c|}{ Cidade de São Paulo - Anúncios } \\
\hline \hline Jornal & Período & Quantidade de Anúncios \\
\hline \hline O Farol Paulistano & $1828-1829$ & 46 \\
\hline \hline O Constitucional & $1853-1854$ & 34 \\
\hline \hline Diário Popular & 1879 & 3 \\
\hline \multicolumn{2}{|c|}{ Quadro 4.4: Anúncios de jornais da cidade de São Paulo no século XIX } \\
\hline
\end{tabular}

\begin{tabular}{|c|c|c|}
\hline \multicolumn{3}{|c|}{ Interior- Anúncios } \\
\hline \hline Jornal & Período & Quantidade de Anúncios \\
\hline \hline Município de Araraquara & 1884 & 2 \\
\hline A Notícia & $1889-1899$ & 16 \\
\hline Gazeta de Campinas & 1870 & 16 \\
\hline \hline A Mocidade & $1874-1875$ & 29 \\
\hline \hline A Actualidade & 1875 & 4 \\
\hline \hline $\begin{array}{c}\text { Diario de Campinas. } \\
\text { Folha Popular }\end{array}$ & 1888 & 5 \\
\hline
\end{tabular}

Quadro 4.5: Anúncios dos jornais do interior de São Paulo no século XIX

No que se refere às cartas de leitores e redatores, o corpus não disponibilizou tal material em jornais do interior do Estado. Portanto, a coleta teve que se restringir ao material coletado em jornais da capital. No quadro 4.6, apresentamos o conjunto de jornais consultados para as duas metades do século XIX, o número e quantidade de cartas selecionadas. Por fim, o quadro 4.7, expõe o número e quantidade das cartas de redatores e a identificação dos periódicos, para as duas metades do século XIX.

\begin{tabular}{||c||c|c||c||}
\hline \multicolumn{4}{|c|}{ Cidade de São Paulo - Cartas de Leitores } \\
\hline \hline Jornal & Período & Número das Cartas & Quantidade de Cartas \\
\hline \hline O Farol Paulistano & 1828 & $219,220,221,222,222$ & 5 \\
\hline A Phenix & 1841 & $224,225,226$, & 3 \\
\hline Correio Paulistano & $1854-1859$ & $228,230,231,232$, & 9 \\
& & $233,234,235,236,237$, & \\
\hline
\end{tabular}

Quadro 4.6: Cartas de leitores de jornais da cidade de São Paulo- século XIX 


\begin{tabular}{|c|c|c|c|}
\hline \multicolumn{4}{|c|}{ Cidade de São Paulo - Cartas de Redatores } \\
\hline Jornal & Período & Número das Cartas & Quantidade de Cartas \\
\hline O Farol Paulistano & $1827-1831$ & $\begin{array}{l}395,397,398,399, \\
401,402,404,406, \\
408,409,410,413, \\
414,415,421,422, \\
426,430,434,437 \\
\end{array}$ & 20 \\
\hline Aurora Paulistana & 1852 & 479 & 1 \\
\hline Correio Paulistano & $\begin{array}{c}1854-1857 \\
1890\end{array}$ & $\begin{array}{c}483,485,486,487,494 \\
495,496,497,498,500 \\
503,504,505,506 \\
531,533,534\end{array}$ & 17 \\
\hline A Opinião & 1889 & 507,530 & 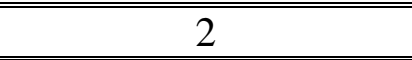 \\
\hline Diário Liberal & 1886 & 528 & 1 \\
\hline Estado de São Paulo & 1891 & 535 & 1 \\
\hline A Nação & $1897-1898$ & $536,542,543$ & 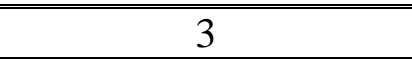 \\
\hline A Noite & 1898-1899 & $548,551,561$, & 3 \\
\hline A Platéa & $1897-1900$ & $552,553,556,557,567$ & 5 \\
\hline
\end{tabular}

\subsection{Fonte documental e fatores linguísticos}

Como se sabe, a pesquisa linguística laboviana dedicada ao PB não só confirmou o pressuposto de que toda mudança é precedida pelo confronto de variantes, como também privilegiou a língua falada em uso nos diferentes segmentos da sociedade, dentro de um continuum do mais formal para o menos formal, como o campo ideal para se observar ambos os fenômenos. Da mesma forma, os estudos gerativistas, consideram a Lingua-E, ou externalizada, como material empírico indispensável para uma abordagem da Língua-I, entendida como a gramática núcleo, ou conhecimento linguístico internalizado na mente/cérebro dos falantes nativos (cf. CHOMSKY, 1986).

Quando empreendemos estudos históricos/diacrônicos não podemos, porém, contar com falantes nativos. Daí a necessidade de se buscar nos bancos de dados o material que sirva de suporte para a veiculação de diferentes gêneros textuais que mais se aproximem da oralidade, no sentido de expressar um embate entre as formas gramaticais de prestígio, valorizadas pelo crivo normativo, e as formas inovadoras. De fato, como os vários projetos sobre o PB culto falado demonstraram, os falantes cultos apresentam uma situação de diglossia. Muitas vezes, as formas inovadoras estão em variação com as formas de prestígio, mas com estatutos gramaticais distintos. As primeiras adquiridas durante a fase da aquisição 
da linguagem. As segundas aprendidas via letramento (cf. KATO, CYRINO \& CORRÊA, 2009).

Os pesquisadores têm sido igualmente unânimes em afirmar que os jornais constituem um desses veículos, uma vez que neles encontramos a concretização de diferentes gêneros textuais, entre eles, carta, editoriais, reportagens, propaganda e outros. Com isso, acreditamos que o corpus que escolhemos pode ser um veículo adequado para expressar a variação presença vs. ausência dos artigos definidos no contexto dos DPs possessivos.

Quanto ao período escolhido, o século XIX, ele também não é trivial, uma vez, que pode servir como ponto de comparação entre o PB e PE. Como mostramos no capítulo II, é nesse século que a realização dos artigos se torna categórica na variedade lusitana.

Por fim, observamos que as variáveis independentes que escolhemos, em particular, os fatores linguísticos, embora em número bastante restrito, são os mais relevantes para um entendimento dos condicionamentos que estão por trás da escolha de uma ou outra variante. Assim, os fatores tipos de verbos e posição argumental, explicitada pelas funções gramaticais sujeito, objeto direto e complemento oblíquo, são relevantes por evidenciarem a presença de sintagmas nominais introduzidos por artigo (DPs), como discutido no capítulo 3. Da mesma forma, o estatuto do possessivo como expressão de posse inalienável vs. posse alienável tem sido fonte de intensa discussão teórica na literatura relevante. Por fim, a presença da preposição como possível condicionadora no embate das variantes foi detectada em vários estudos, entre eles o de Floripi (2008), como discutimos no capítulo II.

Como se viu, a nossa dissertação fez um recorte bastante particular por tratar apenas dos pronomes possessivos de $3^{\mathrm{a}}$ pessoa seu, seus, sua, suas. A nossa escolha tem uma justificativa que se baseia no fato de que as formas possessivas de $3^{\mathrm{a}}$ pessoa se distinguem das formas de $1^{\mathrm{a}}$ e $2^{\mathrm{a}}$ pessoa possessivas pelo seu uso anafórico e por terem sofrido movimentos diacrônicos muito particulares.

\subsection{Apresentação das Variáveis Dependentes e Independentes}

Nesta sessão, listamos, primeiramente, a nossa variável dependente e as variáveis independentes - os fatores de natureza interna e externa condicionadores do fenômeno em variação escolhido como objeto de nosso estudo (cf. quadro 4.8 da página a seguir).

Entre os fatores aqui apresentados, alguns foram retirados de diversos estudos sobre o DP possessivo, como discutido no capítulo 2, e outros foram por nós formulados, com base na leitura de trabalhos, na observação dos dados e nas hipóteses apresentadas. 
Posteriormente, exemplificamos cada variável a partir de nosso corpus, com dois exemplos cada (um da primeira metade e outro da segunda metade do século XIX), buscando dispor melhor dos fatores que nos ajudaram na análise dos dados. Tais fatores nos mostram, de forma quantitativa, o grau condicionador que cada variável apresenta para a determinação do uso do artigo diante do DP possessivo. 
I. VARIÁVEL DEPENDENTE
a) $0=$ ausência do artigo
b) $1=$ presença do artigo

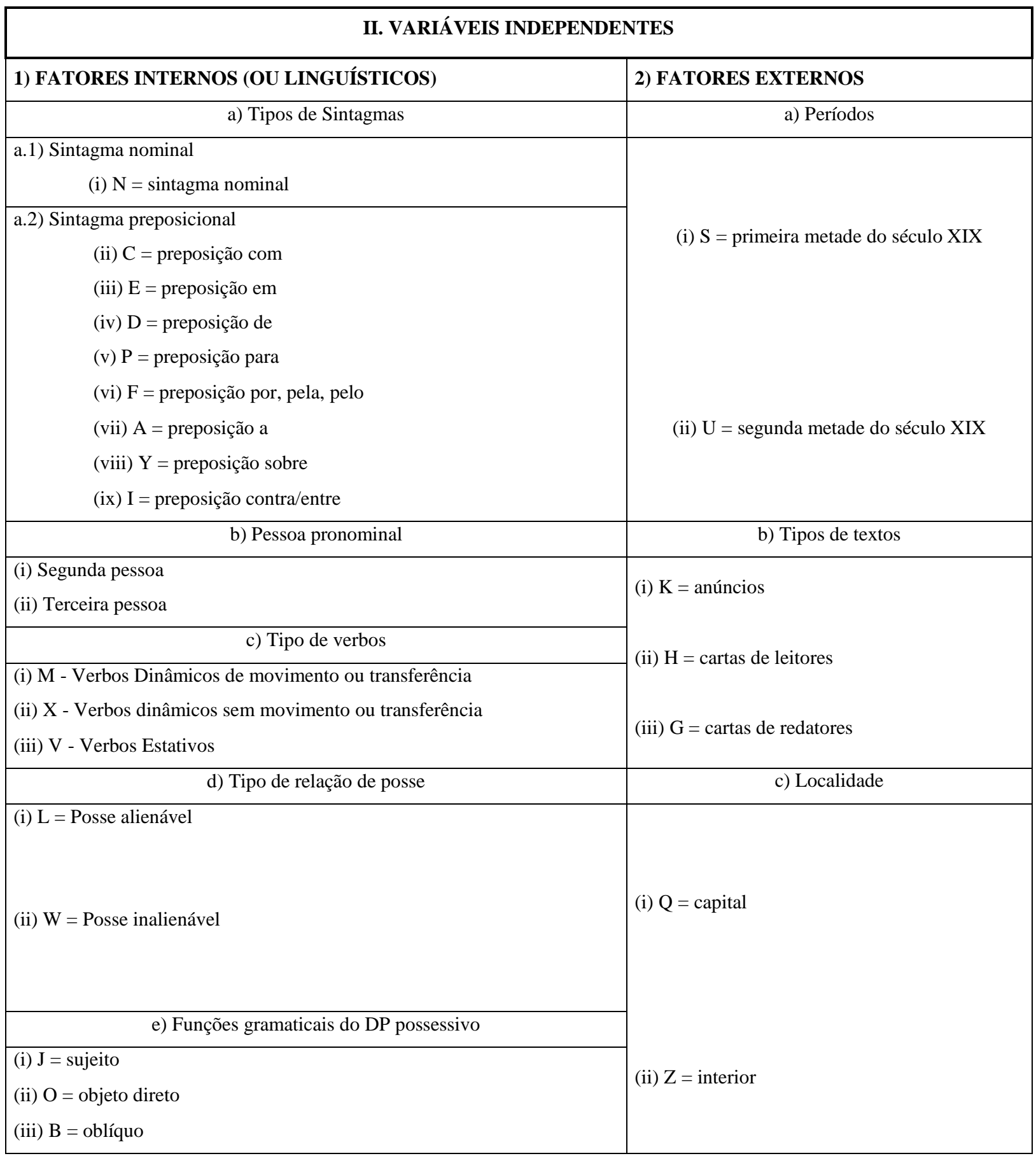

Quadro 4.8: Variáveis dependentes e independentes 


\section{VARIÁVEL DEPENDENTE:}
a) $0=$ ausência do artigo

(1) Legonssat Sabatier, morador na rua do Rosa-|rio, número 24, convida a todas as pessoas que lhe com-|prarão bilhetes de rifa, a satisfazerem sua importan-|cia ate o Domingo proximo 20 do corrente, na cer-|teza de que aquelles Bilhetes que ate então não fo-|rem pagos ficarão por conta do mesmo Sabatier.

O Farol Paulistano, 16 de janeiro de 1828, anúncios

(2) ASA DOS LAVRADOES| TOLEDO \& COMPanhia.| FERRAGISTA| Comunicamos em geral ao commercio, aos nossos freguezes e amigos que, devido ao estado sanitário de São Carlos do Pinhal, mudamos o nosso estabelecimento commercial para Estação onde esperamos, como sempre, receber suas ordens.|Americo Braziliense, 20 de março de 1896.|TOLEDO \& COMPanhia.

A Notícia, 21de junho de 1896, anúncios
b) $1=$ presença do artigo

(3) O Doutor João Baptista Badaró, Italiano formado| em Medicina na Universidade de Pavia, examinado| e approvado no Rio de Janeiro, participa ao Pu-|blico d'esta Cidade que elle se propoêm a exercer| a sua proffissão, para o que o devem procurar em| casa do Doutor José da Costa Cavalho (...).

O Farol Paulistano, 28 de maio de 1828, anúncios

(4) ARMAZEM DA ANCORA|O abaixo assignado communica aos seus numerosos amigos e freguezes, que de volta da Europa, abriu na mesma casa rua 2 esquina da avenida 10, um grande armazem de seccos e molhados, ferragens, que vende a preços baratissimos.

A Notícia, dezembro de 1898, anúncios 


\section{VARIÁVEIS INDEPENDENTES:}

\section{- FATORES INTERNOS (OU LINGUÍSTICOS)}

a) Tipos de Sintagmas
a.1) Sintagma nominal
(i) $\mathrm{N}=$ sintagma nominal

(5) Domingos Monteiro de Carvalho da Villa de Mogi-|mirim faz constar ao Publico que na Cadeia daquella| Villa se achão 2 escravos ainda boçais que forão pe-|gados no Distrito da Freguezia de Caconde (...).Quem for seu dono os| queira procurar.

O Farol Paulistano, 21 de junho de 1828, anúncios

(6) O Doutor Ricardo Gumbleton Daunt obrigado por circuns-|tancias imprevistas á partir da capital antes do dia que havia|designado, não pode cumprir o seu dever despedindo-se pes-|soalmente das pessoas que dignarão honral-o (...).

O Constitucional, 17 de maio de 1854, anúncios

a.2) Sintagma preposicional

(ii) $\mathrm{C}=$ preposição com

(7) Bernardo Guedes Cardozo e Vasconcellos, faz| saber ao respeitavel Público, que todo o negocio fei-|to com sua mulher Antonia Joaquina Leite Pentea-|do, fica nullo para o futuro.

O Farol Paulistano, 18 de outubro de 1828, anúncios

(8) (...) As pessôas que queirão honrar-lhe com sua|proteção, podem dirigir-se ao Hótel Paulista-|no, a onde achão-se a venda os bilhetes.

O Constitucional, 01 de junho de 1853, anúncios 
(iii) $\mathrm{E}=$ preposição em

(9) Ao Capitão Francisco Antonio Pinto| Bastos, morador n'esta Cidade, Rua de São| Gonçalo, casa número 4 fugio um escravo da| Costa, de nome Francisco (...) Há| toda a certeza de estar n'esta Cidade, e quem| o trouxer em sua casa, receberá as alviçaras.

O Farol Paulistano, 16 de fevereiro de 1828, anúncios

(...) Logo que os actuaes administradores desta folha fizeram acquisição da propriedade della, a convidaram-me com insistencia a conservar-me $\underline{\text { em }}$ sua redacção politica (...).

Correio Paulistano, 18 de junho de 1890, carta de redator

(iv) $\mathrm{D}=$ preposição de

(11) Ao Tenente Luiz Francisco da Costa,| morador no Rio de Janeiro, na rua de São| Francisco de Paula número 90, desappareceo| sem motivo algum no $1^{\circ}$.de Julho do cor-|rente anno, um seo escravo ladino de no-|me Francisco, (...) roga-se a| qualquer pessôa, que delle der noticia, ou| o levar á casa de seo Senhor, (...).

O Farol Paulistano, 16 de fevereiro de 1828, anúncios

$30 \$ 000$ de Gratificação| A Quem apprehender a seu se-|nhor ou em cadêa segura, fazendo participação,|o escravo Herculano que desappareceo em 7|do corrente, (...). Protesta-se com todo o|rigor das leis contra quem lhe der couto ou uti-|lisar-se de seus serviços.

O Constitucional, 29 de junho de 1853, anúncios

(v) $\quad \mathrm{P}=$ preposição para

(13) Um Extrangeiro de Nação Portugueza che-|gado ha pouco a esta Cidade, faz publico que abri-|rá sua loje de Alfaiáte, (...) que quizerem hir para| a sua loje, que poder-se-hão dirigir á mesma casa| no dia segunda feira 18 do corrente (...).

O Farol Paulistano, 13 de maio de 1829, anúncios 
(14) (...) Tinhamos aceitado o terreno unico ferido pelo Estado que assim se definiu: "não era folha official...e para suas publicações (do governo) fazia-o a tanto por linha, (...).

Correio Paulistano, 15 de junho de 1890, carta de redator

(vi) $\mathrm{F}=$ preposição por, pela, pelo

José Maria Rodrigo de Carvalho, estabelecido| na Provincia de São Pedro do Sul, vindo a esta Cida-|de, teve a satisfacção de receber aqui destinctos ob-|sequios de varios Senhores, (...), em taes circunstancias agradece por esta maneira, a| unica que lhe é possivel os obsequios que recebeu, e ol interesse que por sua pessoa tomarão os Senhores de São| Paulo (...).

O Farol Paulistano, 24 de junho de 1829, anúncios

O Doutor Ricardo Gumbleton Daunt obrigado por circuns-|tancias imprevistas á partir da capital antes do dia que havia|designado, não pode cumprir o seu dever despedindo-se pes-|soalmente das pessoas que dignarão honral-o por suas relações| durante a sua estada em São Paulo, e por tanto o faz por este an-|nuncio, (...).

O Constitucional, 17 de maio de 1854, anúncios

(vii) $\quad \mathrm{A}=$ preposição a

Do Ouvidor interino desta Cidade Rodrigo| Antonio Monteiro de Barros fugiu um escravo de| nome Manoel, (...).quem o en-|tregar a seu Senhor receberá boas alviçaras.

O Farol Paulistano, 04 de julho de 1829, anúncios

(...) Existe o campo dos Curros que é lar- | go, e o mais espaçoso, ahi se deverião | reunir todos os carros de madeiras, e | quem as quizesse comprar em vez de | dirigir se a SãoFrancisco com mais | meia duzia de passos indo aos Curros, | poderia compral-as a seu gosto: (...).

Correio Paulistano, 29 de julho de 1857, carta de leitor 
(viii) $\quad \mathrm{Y}=$ preposição sobre

(..) Oh! Senhor Redactor, clame contra tanto des- | leixo, tendo em vista o = guta cavat lapi [corroído].... | e póde ser que se acordem e se levantem | dos fôfos colchões de macia penna nossos | patricios, que tomarão sobre seus hombros | esses arduos deveres, que se tornão gostosos | quando se trabalha pelo bem (...).

O Farol Paulistano, 22 de Março de 1828, carta de leitor

(ix) $\quad \mathrm{I}=$ preposição contra/entre (apenas 1 ocorrências de cada)

(20)

(...) como em 1838 e 1839 | quando governava a Provincia um Presidente, | que dizião seus opposicionistas, não curava do melho- | ramento da Provincia: hoje porem que não a go- | verna um espuma ou arribado, mas sim um de $\mid$ seus adversarios chefe do partido chamado pau- | lista, e á quem tantos elogios incessantemente fa- | zem aquelles mesmos, que contra seus antecesso- | res só tinhão insultos, (...).

A Phenix, 24 de Fevereiro de 1841, carta de leitor (...) A camara mandou que Victoriano José Lemes respon- | desse a respeito, este pedio que fosse uma commissão no- | meada pela camara d'entre os seus membros, (...).

Correio Paulistano, 26 de Março de 1859, carta de leitor

\section{b) Pessoa pronominal}

(i) Segunda pessoa

(...) Se era de todos, para que nomeou | Sua Excelência somente as pessoas que tem direito | a semelhante obsequio?, e se era só de alguns | poucos eleitos, que importava ao público a|o saber se Sua Excelênciatinha ou não tido tem- | po para se despidir dos seus amigos, ou dos | poucos eleitos que o cortejavão? Não é que | eu censure a Vossa mercê Senhor Redactor por inse- | rir um semelhante annuncio; (...). 
(23) Senhor Redactor. - Não se póde ser auto- | ridade hoje em dia! (...)|| Todavia por distracção deixe-me gastar | um canto de sua folha. || (...).

Correio Paulistano, 22 de Julho de 1854, carta de leitor

(ii) Terceira pessoa

(24)

(...) Mas o peior foi | que os Paulistas com toda a sua rusticidade | já forão honrados com uma Proclamação de | despedida geral da Propria Pessôa de Sua Majestade | o IMPERADOR, e por isso talvez os poucos | eleitos não fizessem todo o aprêço, | que Sua Excelência esperava, (...).

O Farol Paulistano, 30 de Abril de 1828, carta de leitor

O decano da imprensa paulistana tem nestes ultimos tempos tomado feição sympathica, já quanto aos assumptos da ordem publica a que aborda, já quanto ao seu desenvolvimento intellectual e material na redacção e administração. $\|($...).

A Platéa, 27 de junho de 1900, carta de redator

c) Tipo de verbos

(i) M - Verbos Dinâmicos de movimento ou transferência

(26) (...) Isto sirva de resposta a certo Senhor Correspondente do Rio, que enviou sua correspondencia para o seu particularissimo da Villa de Sanctos, para d'alli nos ser enviada. (...).

O Farol Paulistano, 30 de Janeiro de 1830, carta de redator

(27) $\quad \mathrm{Eu} \mid$ que presenciava o facto, dirigi-me então á loja $\mid$ - reclamando a minha propriedade e | o caixeiro da loja respondeu-me que não | poderia entregar-me sem ordem de seu | amo. ||

O Farol Paulistano, 20 de Setembro de 1854, carta de leitor 
(ii) $\mathrm{X}$ - Verbos dinâmicos sem movimento ou transferência

Bernardo Guedes Cardozo e Vasconcellos, faz| saber ao respeitavel Público, que todo o negocio fei-|to com sua mulher Antonia Joaquina Leite Pentea-|do, fica nullo para o futuro.

O Farol Paulistano, 18 de outubro de 1828, anúncios

A imparcialidade que nos temos imposto manda que acolhamos com todo o prazer a correspondencia do Senhor Doutor Gabriel, muito embora o seu final se revestisse de um espirito mais ardente. || Haverá logar á resposta. || A Redacção.

Correio Paulistano, 01 de julho de 1854, carta de redator

(iii) V - Verbos Estativos

(30)

Rua do Rozario Logea de fazenda secca| casa número 13, acha-se avenda uma porção| de Livros, intitula-se Medicina Curativa,| em $4 .^{\circ} 1$ vollume preço $2 \$$ réis muito util para| uma Casa de familia. Seu Autor é José Ma-|ria Bom-Tempo, Medico de S.M.I. estes| Livros são chegados proximamente da| Côrte.

O Farol Paulistano, 12 de março de 1828, anúncios

A publicação será gratuita, visto como unicamente desejamos que o Correio Paulistano contenha interesse pela variedade de seus escriptos e pela parte noticiosa que procuraremos alargar. || São Paulo - 1854 - Typographia IMPARCIAL de Marques \& Irmão.

Correio Paulistano, 06 de julho de 1854, carta de redator

d) Tipo de relação de posse

(i) L = Posse alienável

(32) Um Extrangeiro de Nação Portugueza che-|gado ha pouco a esta Cidade, faz publico que abri-|rá sua loje de Alfaiáte, (...).

O Farol Paulistano, 13 de maio de 1829, anúncios 
Senhores Redactores - Principiarei por con- | gratular-me com Vossas mercês, por já | termos, em São Paulo, um jornal dedicado | a preencher o vacuo que havia, (...) procurando satisfazer a todas as | classes, permitta que me utilize de um | canto de sua folha para chamar a atten- | ção da camara municipal para o deleixo | de seus fiscaes, (...).

Correio Paulistano, 05 de julho de 1854, carta de leitor

(ii) $\quad \mathrm{W}=$ Posse inalienável $^{93}$

(34) (...) Oh! Senhor Redactor, clame contra tanto des- | leixo, tendo em vista o = guta cavat lapi [corroído].... | e póde ser que se acordem e se levantem | dos fôfos colchões de macia penna nossos | patricios, que tomarão sobre seus hombros | esses arduos deveres, (...).

Farol Paulistano, 22 de março de 1828, carta de leitor

RARIDADE || Erão hoje 5 horas da tarde, quando, | estando eu em minha casa, chegou | um homem, que parecia marinhei- | ro, de cara sinistra, tez morena, quei- | xo perpendicularmente longo, com | voz rouca e cavernoza, soltando bafo- | radas asquerozas, arreganhando seus $\mid$ dentes semelhantes ao de um + cão $\mid$ defila, (...)o $\mid$ escrivão da provedoria, sincero e inof- | fensivo com é, não costumando a fa- | zer parte, nas miseraveis intrigas, (...).

Correio Paulistano, 30 de dezembro de 1857, carta de leitor

Senhores Redactores. || Quando falleceo João Rodrigues de Camargo Pi- | res, Tio do actual Secretario do senhor Tobias, es- I perava se que sua herdeira achasse muito dinhei- | ro, pois dizia se, que bastante possuia o dicto fal- | lecido, e que mesmo dinheiro em ouro havia nas | vesperas de sua morte elle recebido. Mas a her- | deira sua Mãe, e Avó do dicto Secretario o Doutor | Gabriel, nada achou (...).

A Phenix, 23 de janeiro de 1841, carta de leitor

\footnotetext{
${ }^{93}$ Como posse inalienável colocamos as posses relativas a parentesco, parte-todo e parte-corpo.
} 
Disse-nos que vem a São Paulo, a passeio, e á procura de oboloos(sic) para a subsistencia e de seu pae que é cego e está no Rio (...).

A Nação, 25 de outubro de 1897, carta de redator

e) Funções gramaticais do DP possessivo

(i) $\quad \mathrm{J}=$ sujeito

(38) Perdeo-se no Hospital, onde tem morado os Co-|lonos Alemãos, uma caixa de prata com lettras| iniciaes do nome de seu dono: roga se portanto a| qualquer pessôa, que a tenha comprado, haja de| a entregar no mesmo Hospital, onde seu dono lhe| satisfará a quantia por que tiver comprado a re-|ferida caixa.

O Farol Paulistano, 21 de junho de 1828, anúncios

60-RUA DIREITA- 60|| O João Palmeira acaba de abrir na casa acima sua fabrica de licores e bebidas alcoholicas, onde se encontrará tudo o que é peculiar destes estabelecimentos. Seus antigos freguezes são rogados a preferir seus productos, vantajosos em preços e em qualidades.

Gazeta de Campinas, 12 de junho de 1870, anúncios

(ii) $\mathrm{O}=$ objeto direto

(40) A muitos cidadãos caridozos se abre uma porta franca, e segura para fazerem effectiva beneficencia, se o perigo de mal empregar sua caridade... Paulistas! (...) estão para embarcar trez Paulistas, (...).

Gazeta de Campinas, 07 de março de 1827, carta de redator

(41) Um Extrangeiro de Nação Portugueza che-|gado ha pouco a esta Cidade, faz publico que abri-|rá sua loje de Alfaiáte, (...).

O Farol Paulistano, 13 de maio de 1829, anúncios 
(iii) $\mathrm{B}=$ oblíquo $^{94}$

(42) Na rua do Ouvidor, número5, ha para vender-|se uma escrava crioula de 20 annos de edade, e bem| parecida: quem á quizer dirija se a tractar com seu|dono.

O Farol Paulistano, 30 de dezembro de 1828, anúncios

A Francisco das Chagas mora-|dor na freguezia da Cutia fugio a tres an-|nos mais ou menos um escravo pardo|bem barbado, (...).Quem o capturar e entregar a seu|senhor na referida freguezia será bem|gratificado.

O Constitucional, 11 de maio de 1853, anúncios

- FATORES EXTERNOS (extralinguísticos)

a) Períodos

(i) $\mathrm{S}=$ primeira metade do século XIX

(44) Rogamos a todos os Cidadãos nos queirao illustrar com seus talentos e lembranças, (...).

Farol Paulistano, 07 de fevereiro de 1827, carta de redator

Senhor Redactor - Como em o seu número 97 | de hoje me offerece occasião de desabafo | contra a Camara d'esta Cidade a quem | incumbe a sua policia quero desabafar meu | censibilisado coração, (...).

Farol Paulistano, 22 de março de 1828, carta de leitor

(46) Um Extrangeiro de Nação Portugueza che-|gado ha pouco a esta Cidade, faz publico que abri-|rá sua loje de Alfaiáte, (...).

O Farol Paulistano, 13 de maio de 1829, anúncios

\footnotetext{
${ }^{94} \mathrm{O}$ complemento oblíquo inclui todo complemento/adjunto introduzido por preposição.
} 
(ii) $\mathrm{U}=$ segunda metade do século XIX

(47)

(...) Todos que se achão encarregados de empresas d’esta natureza não ignorarão quaõ difficil é venser taes embaraços e por isso muito nos admiramos de que o Mercantil d'esta cidade que tem soffrido do mesmo mal nos queira envolver na sua mania de tudo censurar sem criterio.

Aurora Paulistana, 25 de março de 1852, carta de redator

Senhor Redactor: - Tem de realisar-se | muito breve o contracto para a illu- | minação da cidade, e como eu sou | um dos moradores de um dos arra- | baldes da cidade, onde ha lampiões | pro formula, e que nunca se acendem, | aproveito-me da sua recenascidafo- | lhapara pedir á Sua Excelência que descarre- | gue a mão no applicar as multas (...)

Correio Paulistano, 28 de junho de 1854, carta de leitor

Compra-se algumas carroças de aterro em bom estado arreiadas|e com animaes, sendo seus preços rasoaveis,|recebe-se tambem á jornal. Trata-se a rua Episcopal numero 8 sobrado,|das 10 horas da manhã às 3 da tarde.

Diário Popular, 09 de janeiro de 1879, anúncios

b) Tipos de textos

(i) $\quad \mathrm{K}=$ anúncios

Ao Capitão Francisco Antonio Pinto| Bastos, morador n'esta Cidade, Rua de São| Gonçalo, casa número 4 fugio um escravo da| Costa, de nome Francisco (...) Hál toda a certeza de estar n'esta Cidade, e quem| o trouxer em sua casa, receberá as alviçaras.

O Farol Paulistano, 16 de fevereiro de 1828, anúncios

À PRAÇA|Eu abaixo assignado declaro que comprei ao senhor Joaquim Machado de Lemos,|livre e desembaraçado de qualquer onus, o seu armazem de seccos e molhados,|sito à rua do Seminario numero 8. Luiz Turri.

Diário Popular, 03 de janeiro de 1879, anúncios

(ii) $\mathrm{H}=$ cartas de leitores 
Senhor Redactor. - Depois de cessar por um pouco essa abundante chuva, que | desde o anno passado tem caido todos os | dias sem interrupção, quiz ver o estado da | varzea do Carmo, e se com effeito tinha- | se conseguido o fim d'esgotál-a, dirigi-me | até a chamada ponte do ferrão, que foi | entulhada, e vi que o pêso das aguas, que | não respeita grandes barreiras, quanto | mais ás fracas havia aberto o seu antigo | caminho,(...).

Farol Paulistano, 15 de março de 1828, carta de leitor

Senhor Redactor: - Tem de realisar-se | muito breve o contracto para a illu- | minação da cidade, e como eu sou | um dos moradores de um dos arra- | baldes da cidade, onde ha lampiões | pro formula, e que nunca se acendem, | aproveito-me da sua recenascidafo- | lhapara pedir á Sua Excelência que descarre- | gue a mão no applicar as multas (...).

Correio Paulistano, 28 de junho de 1854, carta de leitor

$\mathrm{G}=$ cartas de redatores

Senhor Aprendiz de Ferreiro \| Temos à vista a sua carta acerca da Proposta no Regimento da Cavallaria número 17, a qual recebemos hontem à noite, (...).

Farol Paulistano, 21 de fevereiro de 1827, carta de redator

A imparcialidade que nos temos imposto manda que acolhamos com todo o prazer a correspondencia do Senhor Doutor Gabriel, muito embora o seu final se revestisse de um espirito mais ardente. || Haverá logar á resposta. || A Redacção.

Correio Paulistano, 01 de julho de 1854, carta de redator

c) Localidade

(i) $\quad$ Q = capital

(56) Aos Senhores Do interior: \| A redacção do Correio, (...) Todavia isso não impede que outros Senhores Nos enviem seus escriptos, quanto possam utilisar. (...).

Farol Paulistano, 06 de julho de 1854, carta de redator 
(...) Se era de todos, para que nomeou | Sua Excelência somente as pessoas que tem direito | a semelhante obsequio?, e se era só de alguns | poucos eleitos, que importava ao público a| o saber se Sua Excelênciatinha ou não tido tem- | po para se despidir dos seus amigos, ou dos | poucos eleitos que o cortejavão? Não é que | eu censure a Vossa mercê Senhor Redactor por inse- | rir um semelhante annuncio; (...).

Farol Paulistano, 30 de abril de 1828, carta de leitor

Jorge scorrar Ferreiro e Engenheiro|Participa ao respeitavel publico prin|cipalmente aos seus freguezes, que mu-|dou sua fabrica para o largo da Cadea es|quina da rua da Esperança, (...).

O Constitucional, 11 de maio de 1853, anúncios

(ii) $\quad \mathrm{Z}=$ interior

Compra-se algumas carroças de aterro em bom estado arreiadas|e com animaes, sendo seus preços rasoaveis,|recebe-se tambem á jornal. Trata-se a rua Episcopal numero 8 sobrado,|das 10 horas da manhã às 3 da tarde.

Diário Popular, 09 de janeiro de 1879, anúncios

Para a quantificação das frequências da variável dependente e dos fatores (variáveis independentes) enumerados acima foi utilizado o sistema estatístico GoldVarb (2001 - versão modificada do programa Varbrul, de David Rend e David Sankoff), que possibilita, além da quantificação dos dados, fazer o cruzamento entre as diversas variáveis que serão encontradas no corpus.

Dessas variáveis independentes, o pacote de programas computacionais GoldVarb selecionou como estaticamente significativos para o apagamento do artigo os fatores: tipo de sintagma (nominal e preposicional), pessoa pronominal (segunda ou terceira) e tipo de verbos (verbos dinâmicos de movimento ou transferência, verbos dinâmicos sem movimento ou transferência e verbos estativos).

Porém, não só esses fatores foram passivos de análise. Os gráficos e tabelas que se seguem mostram cruzamentos possíveis de serem feitos pelo programa computacional, e sua respectiva importância para o presente estudo. 


\subsection{Resultados Quantitativos}

\subsubsection{Presença $x$ ausência do determinante diante do possessivo}

Ao investigar o uso do possessivo seu (s), sua (s) na primeira e segunda metades do século XIX na amostra constituída de anúncios, cartas de leitores e redatores, foram encontradas 365 ocorrências. Desse total, 131 (35\%) ocorrem em textos da primeira metade do século XIX e 234 (65\%) na segunda metade, como mostram o gráfico 4.1 e tabela 4.1.

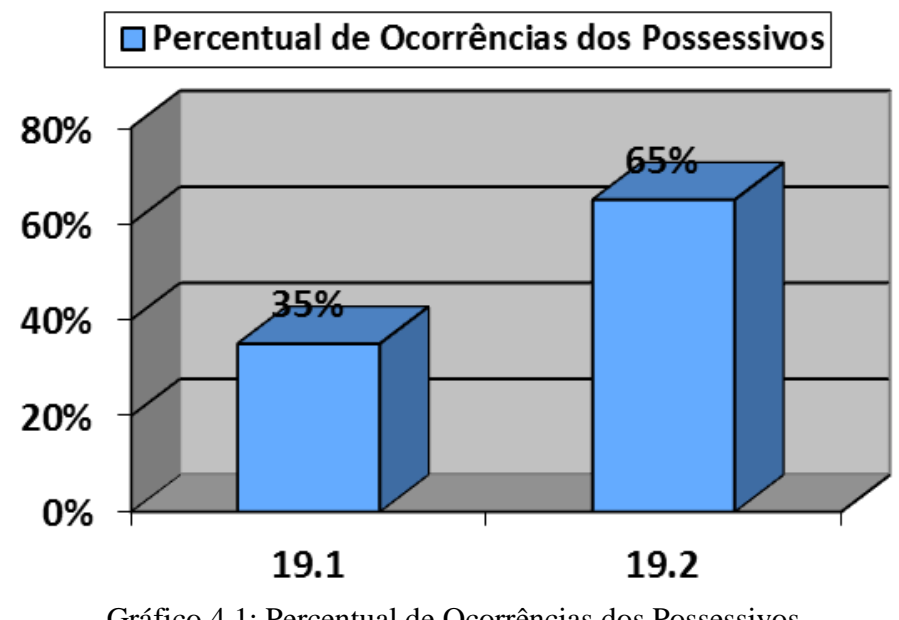

\begin{tabular}{|c|c|}
\hline Período & Número de Ocorrências \\
\hline $\mathbf{1 9 . 1}$ & $131 / 365(35 \%)$ \\
\hline $\mathbf{1 9 . 2}$ & $234 / 365(65 \%)$ \\
\hline
\end{tabular}

Tabela 4.1: Número de Ocorrências do Possessivo

Com relação à variável dependente, presença versus ausência do artigo definido diante do possessivo, temos o seguinte panorama: na primeira metade do século XIX, de um total de 131 ocorrências, $58 \%$ apresenta ausência do determinante; na segunda metade, de um total de 234 ocorrências, obtivemos os mesmos resultados da primeira metade. Da mesma forma, coincidiram os percentuais de presença do determinante (42\%). Vejamos os gráficos 4.2 e 4.3 e a tabela 4.2 a seguir: 


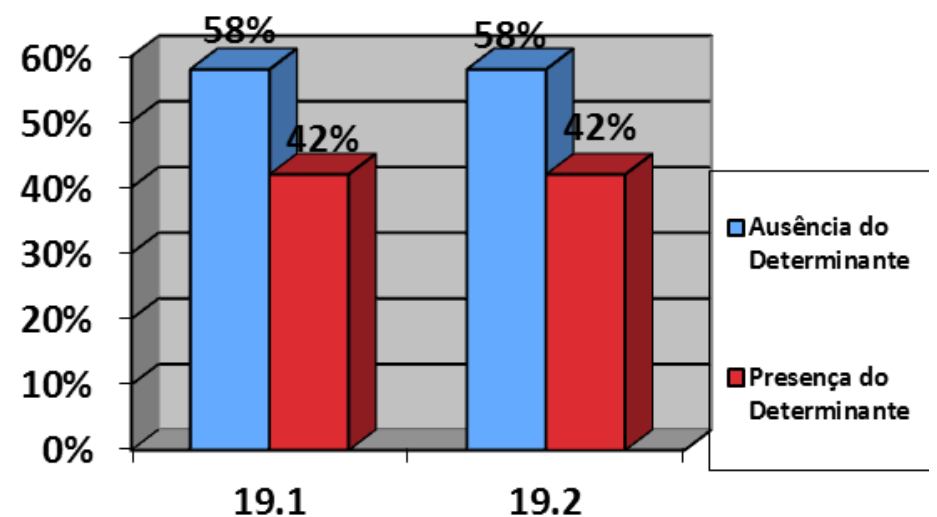

Gráfico 4.2: Ausência versus presença do determinante por período

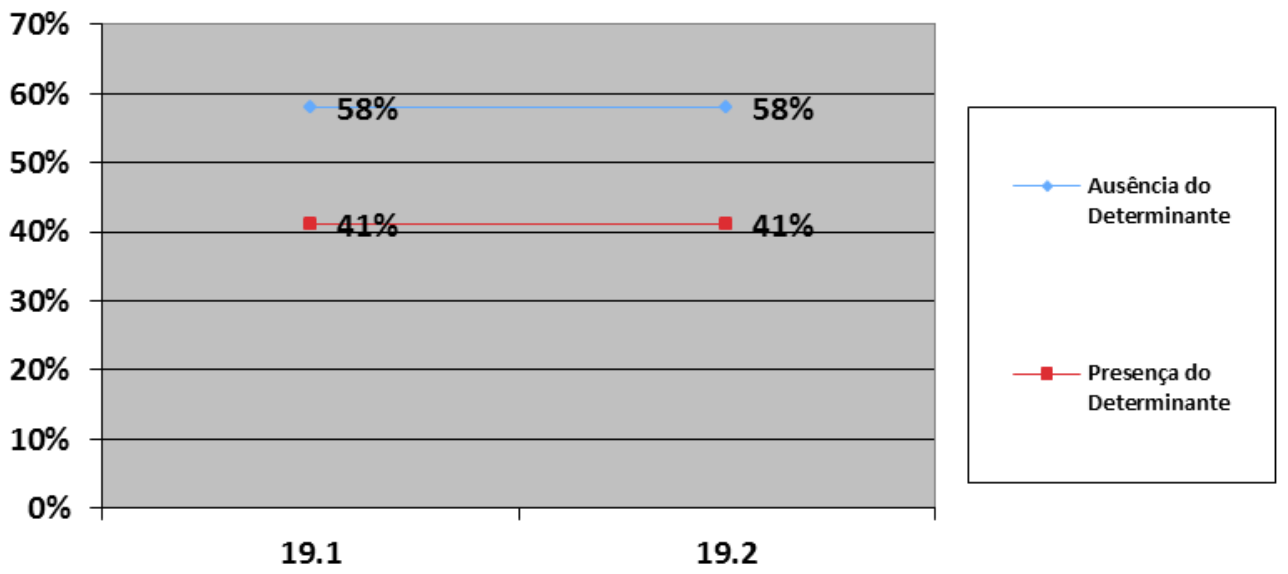

Gráfico 4.3: Ausência x Presença do Determinante por Período

\begin{tabular}{|c|c|}
\hline & Número de Ocorrências \\
\hline Ausência do Determinante & $215 / 365(58 \%)$ \\
\hline Presença do Determinante & $150 / 365(42 \%)$ \\
\hline
\end{tabular}

Tabela 4.2: Número de Ocorrências do Determinante

Embora tenhamos obtido resultados idênticos para o século XIX como um todo, faremos uma análise detalhada dos fatores anteriormente citados com o objetivo de averiguar quais deles o programa seleciona para favorecer ou não o uso do determinante. Somente dessa forma conseguiremos reconhecer uma mudança linguística em progresso ou uma variável estável. 


\subsubsection{Tipos de Sintagma}

\subsubsection{DP possessivo sem preposição}

Iniciamos a nossa análise quantitativa referente a cada um dos fatores independentes a partir da natureza do sintagma nominal, ou seja, DP sem preposição e DP com preposição. Antes de olharmos os dados contrapondo os dois períodos em foco (primeira e segunda metades do século XIX), analisamos o uso do determinante considerando a presença e a ausência da preposição em conjunto (os dois períodos analisados), como verificamos no gráfico 4.4 e tabela 4.3 abaixo.

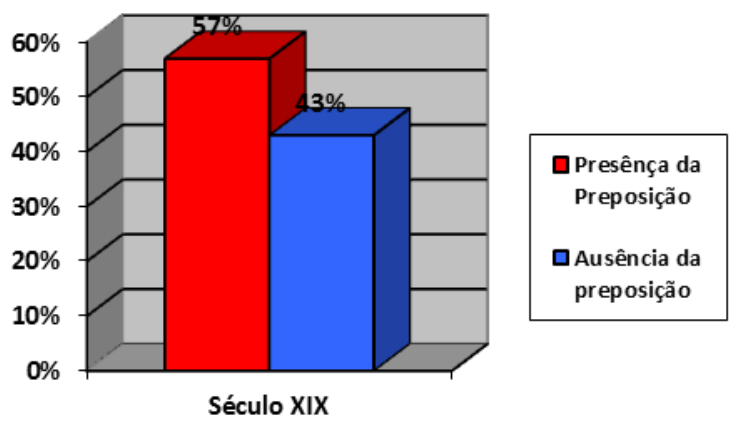

Gráfico 4.4: Ausência versus presença da preposição

\begin{tabular}{|c|c|}
\hline Século XIX & Frequência \\
\hline Presença da Preposição & $208 / 365(57 \%)$ \\
\hline Ausência da Preposição & $157 / 365(43 \%)$ \\
\hline
\end{tabular}

Tabela 4.3: Ausência versus presença da preposição

É possível identificar, em um panorama geral, que um pouco mais da metade das ocorrências dos sintagmas possessivos apresentam uma preposição em sua estrutura. Basta saber se a presença dessa preposição favorece o uso do artigo ou não, como mostram o gráfico 4.5 e tabela 4.4 abaixo. 


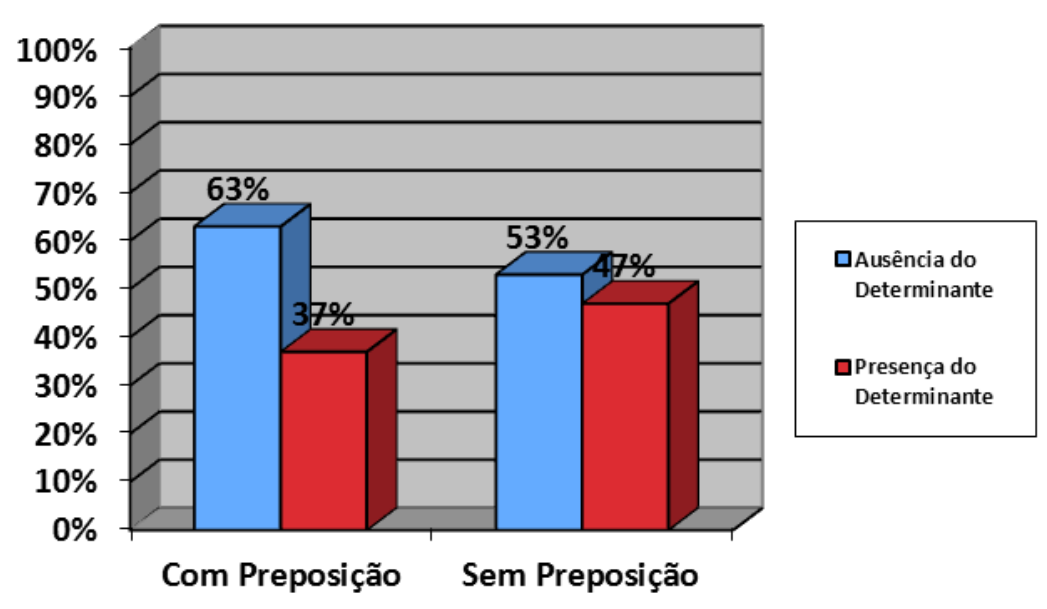

Gráfico 4.5: Ausência versus presença do determinante com e sem preposição no século XIX

\begin{tabular}{|c|c|c|}
\hline Século XIX & Com preposição & Sem preposição \\
\hline Ausência do Determinante & $131 / 208(63 \%)$ & $83 / 157(53 \%)$ \\
\hline Presença do Determinante & $77 / 208(37 \%)$ & $74 / 157(47 \%)$ \\
\hline Total & $208 / 365(57 \%)$ & $157 / 365(43 \%)$ \\
\hline
\end{tabular}

Tabela 4.4: Ausência versus presença do determinante com e sem preposição

Como vemos no gráfico 4.6, gráfico 4.7 e tabela 4.5, não há uma diferença percentual marcante entre a presença e ausência de determinantes com DPs possessivos sem preposição nos dois períodos, uma vez que a diferença entre eles não passa de 6\%. Das 157 ocorrências, $53 \%$ é o percentual, em ambas as metades do século XIX, da ausência de determinante diante de DPs possessivos sem preposição. Da mesma forma, obtivemos o mesmo percentual $43 \%$, nos dois períodos, referente à presença do determinante.

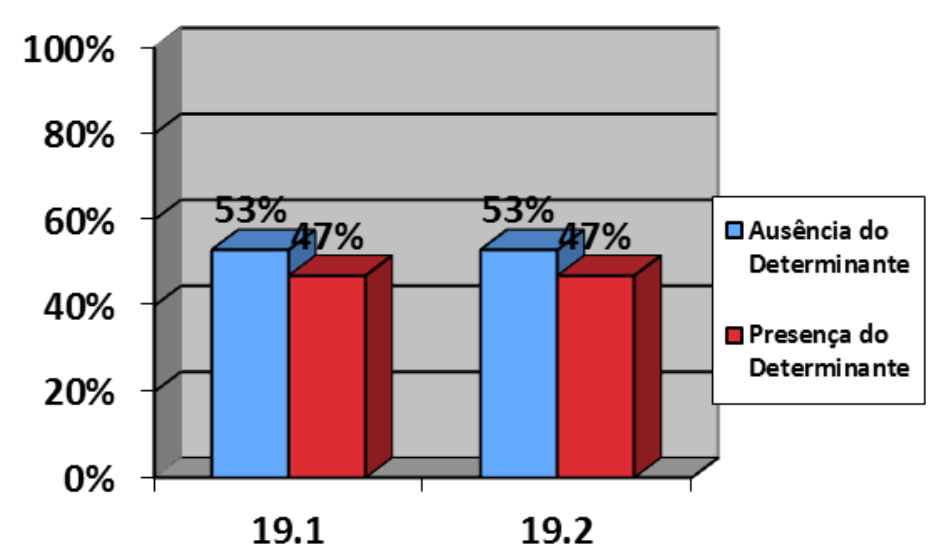

Gráfico 4.6: Ausência versus presença em DPs possessivos sem preposição 


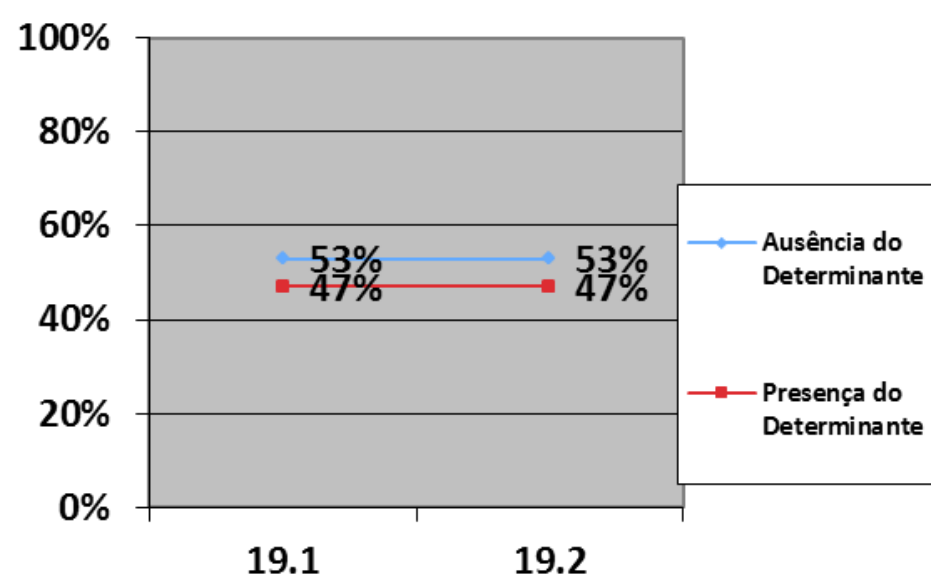

Gráfico 4.7: Ausência versus presença em DPs possessivos sem preposição

\begin{tabular}{|c|c|c|}
\hline Possessivos sem Preposição & $\begin{array}{c}\mathbf{1 9 . 1} \\
\text { Frequência }\end{array}$ & $\begin{array}{c}\mathbf{1 9 . 2} \\
\text { Frequência }\end{array}$ \\
\hline Ausência do Determinante & $29 / 55(53 \%)$ & $54 / 102(53 \%)$ \\
\hline Presença do Determinante & $26 / 55(47 \%)$ & $48 / 102(47 \%)$ \\
\hline Total & $55 / 157(35 \%)$ & $102 / 157(65 \%)$ \\
\hline
\end{tabular}

Tabela 4.5: Ausência versus presença em DPs possessivos sem preposição

Para os dados em que há ocorrência de PPs (gráficos 4.6, 4.7 e tabela 4.4), os dados nos revelam percentuais mais representativos. É possível perceber uma ausência maior do determinante $(62,5 \%)$ quando o sintagma possessivo é preposicionado. Especificamente, $62 \%$ (46/75) foi o percentual no qual o determinante é nulo fonologicamente diante de PPs possessivos na primeira metade do século XIX e 63\% (85/133) para a segunda metade.

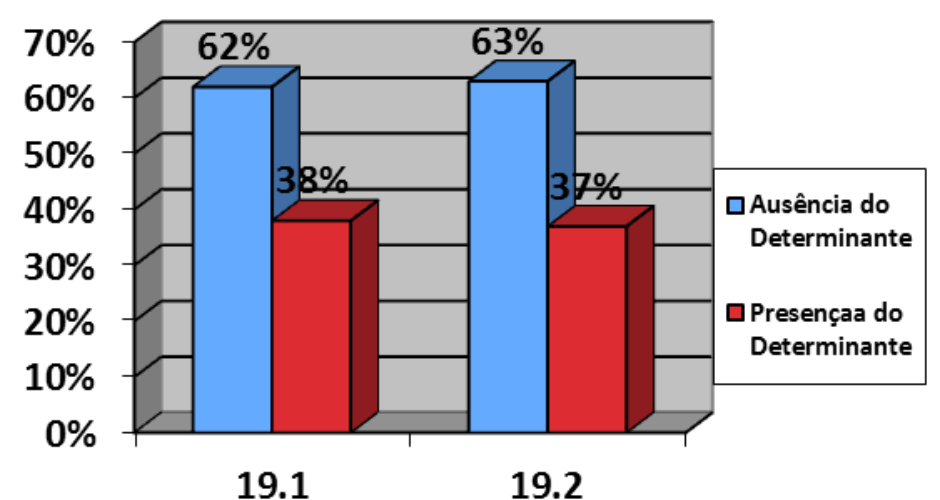

Gráfico 4.8: Ausência versus presença em DPs possessivos com preposição 


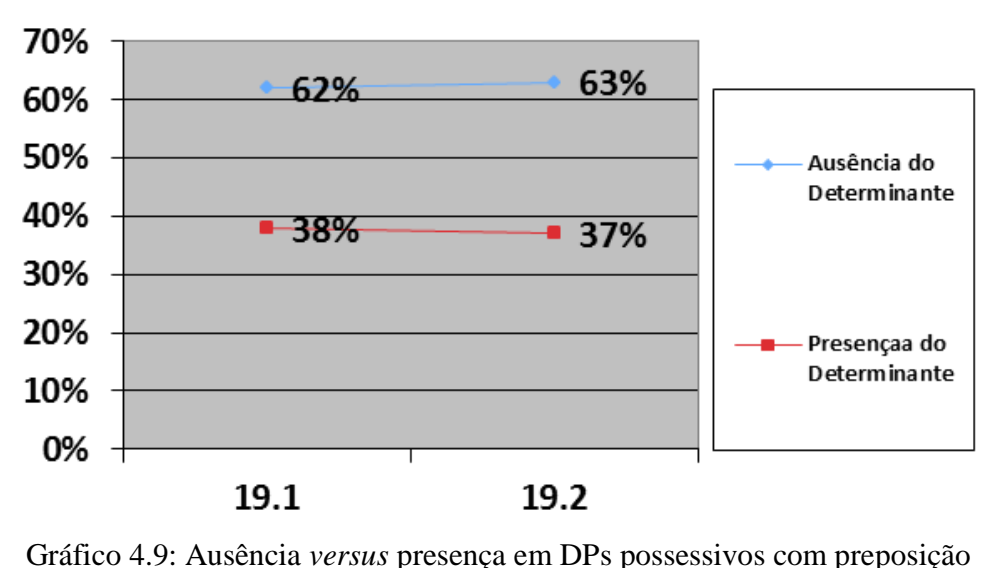

\begin{tabular}{|c|c|c|}
\hline Possessivos com Preposição & $\begin{array}{c}\mathbf{1 9 . 1} \\
\text { Frequência }\end{array}$ & $\begin{array}{c}\mathbf{1 9 . 2} \\
\text { Frequência }\end{array}$ \\
\hline Ausência do Determinante & $46 / 75(62 \%)$ & $85 / 133(63 \%)$ \\
\hline Presença do Determinante & $28 / 75(38 \%)$ & $49 / 133(37 \%)$ \\
\hline Total & $75 / 208$ & $133 / 208$ \\
\hline
\end{tabular}

Tabela 4.6: Ausência versus presença em DPs possessivos com preposição

De acordo com os dados, o número de ocorrências dos sintagmas sem preposição não nos dá um cenário de mudança em progresso, apenas de uma variação que ainda está atuando. No entanto, quando olhamos os sintagmas possessivos preposicionados, percebemos que esses favorecem a ausência do determinante, uma vez que o percentual atingido é a média de $62,5 \%$, corroborando estudos anteriores (Floripi (2008) - cf. capítulo 2).

\subsubsection{Diferentes tipos de preposição introdutoras de DPs possessivos (PP)}

Em 365 ocorrências de sintagmas nominais com possessivos, 208 (57\%) ocorrem com preposição. Das preposições usadas, as mais recorrentes foram: com, de, em, para, por e $a$. Houve também uma única ocorrência das preposições entre, contra e sobre que, por apresentar uma porcentagem muito baixa, não foram computadas.

No gráfico 4.10 , tabelas 4.7 e 4.8 a seguir, que representam o uso das diferentes preposições diante do sintagma nominal possessivo e a presença do determinante, obtivermos os percentuais de 28/208 (14\%) para a preposição com, 23/208 (11\%) para a preposição em, 84/208 (41\%) para a preposição de, 6/208 (3\%) para a preposição para, 14/208 (7\%) para a preposição por e 50/208 (24\%) para a preposição $a$. 


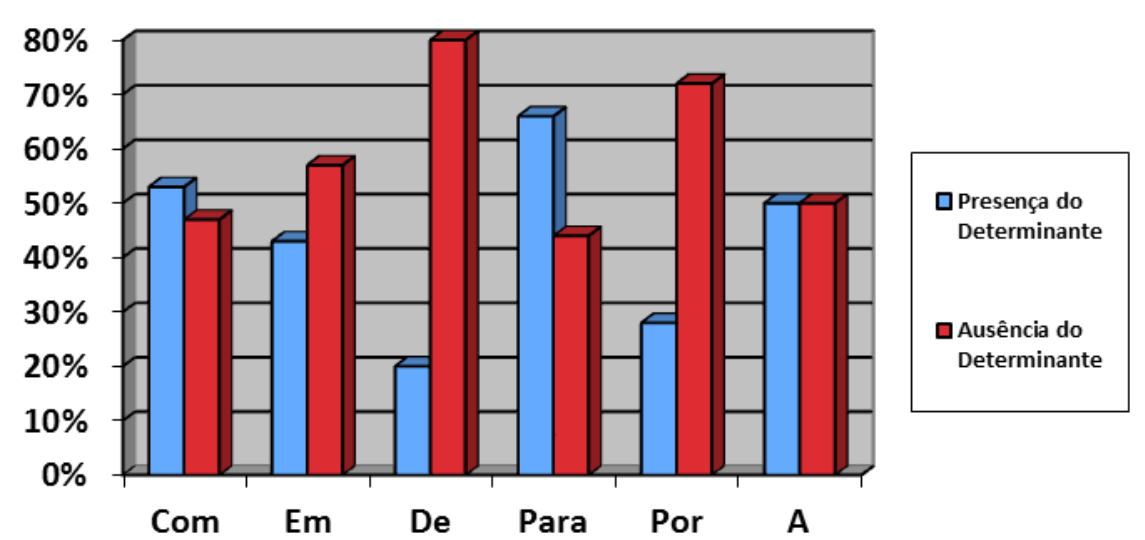

Gráfico 4.10: Ausência x Presença do determinante diante dos tipos de preposição

\begin{tabular}{|c|c|}
\hline Preposição & Número de Ocorrências \\
\hline COM & $28 / 208(14 \%)$ \\
\hline EM & $23 / 208(11 \%)$ \\
\hline DE & $84 / 208(41 \%)$ \\
\hline PARA & $6 / 208(3 \%)$ \\
\hline POR & $14 / 208(7 \%)$ \\
\hline A & $50 / 208(24 \%)$ \\
\hline
\end{tabular}

Tabela 4.7: Número de ocorrências dos diferentes tipos de preposição

Quando fazemos o cruzamento dos diferentes tipos de preposição e variável dependente, obtemos os resultados percentuais expressos na tabela 4.6.

O fato do programa GoldVarb 2001 gerar um peso relativo para os tipos de preposição e ainda julgar esse fator como peso 1 é de extrema importância para os nossos estudos, e mostra indícios de um percurso próximo ao PE quando este ainda estava em variação (século XVI).

\begin{tabular}{|c|c|c|c|}
\hline Preposição & $\begin{array}{c}\text { Frequência sem } \\
\text { Determinante }\end{array}$ & $\begin{array}{c}\text { Frequência com } \\
\text { Determinante }\end{array}$ & $\begin{array}{c}\text { Peso Relativo } \\
\text { de não realização) }\end{array}$ \\
\hline Sem preposição & $83 / 157(53 \%)$ & $74 / 157(47 \%)$ & 0,422 \\
\hline COM & $12 / 28(46 \%)$ & $15 / 28(54 \%)$ & 0,386 \\
\hline EM & $13 / 23(57 \%)$ & $10 / 23(43 \%)$ & 0,517 \\
\hline DE & $67 / 84(79 \%)$ & $17 / 84(21 \%)$ & 0,777 \\
\hline PARA & $2 / 6(34 \%)$ & $4 / 6(66 \%)$ & 0,179 \\
\hline POR & $10 / 14(72 \%)$ & $4 / 14(28 \%)$ & 0,608 \\
\hline A & $25 / 50(50 \%)$ & $25 / 50(50 \%)$ & 0,305 \\
\hline
\end{tabular}

Observa-se que as preposições com e $a$ são irrelevantes para esse critério de seleção, uma vez que o percentual de suas ocorrências permanece na casa dos 50\%. A preposição 
para, por sua vez, aparece em 3\% dos dados e desfavorece consideravelmente o uso do determinante $(34 \%)^{95}$. A preposição em desfavorece o uso do determinante de forma equilibrada $(57 \%$,$) . As preposições de e por são as que mais se destacam entre as demais, uma$ vez que desfavorecem de forma significativa o uso do determinante (79\% e 72\%, respectivamente). Como visto anteriormente, o não uso da preposição desfavorece o uso do determinante em $53 \%$.

Ao analisarmos o peso relativo, que leva em conta todos os fatores rodados no programa, percebemos que as preposições que desfavorecem o não uso do artigo são: com $(\mathrm{PR}=0,353), \operatorname{para}(\mathrm{PR}=0,276)$ e $a(\mathrm{PR}=0,305)$. O não uso da preposição também desfavorece o não uso do artigo $(P R=0,422)$. A preposição $\mathrm{em}$, por sua vez, não influi na análise $(\mathrm{PR}=0,502)$. Já as preposições que favorecem o não uso do artigo são: de $(\mathrm{PR}=$ $0,768)$ e $\operatorname{por}(\mathrm{PR}=0,608)$.

Nos gráficos 4.11 e 4.12 e tabela 4.9 ainda trazemos o progresso da variável independente por período, para melhor visualizarmos seu percurso.

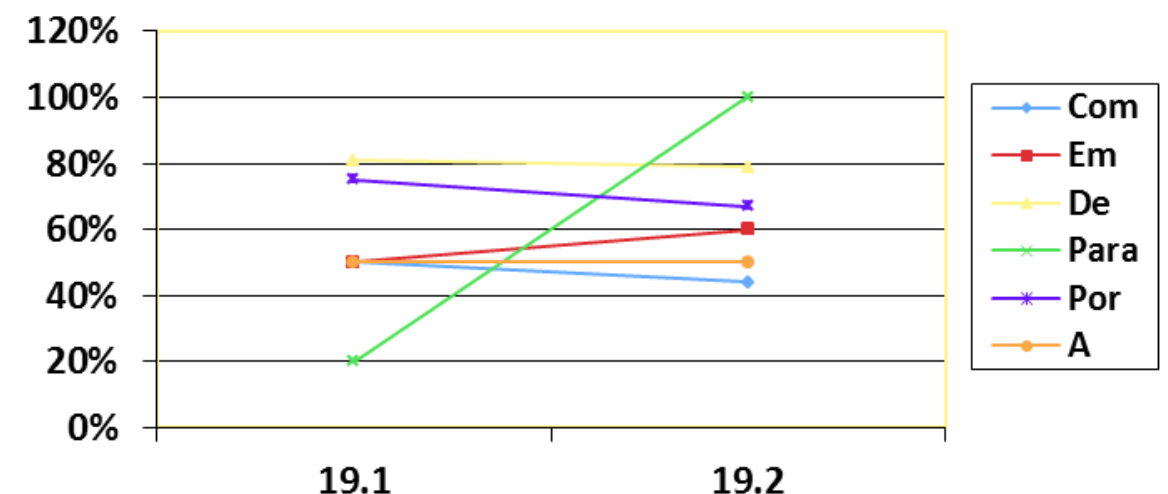

Gráfico 4.11: Ausência do determinante diante dos diferentes tipos de preposição por período

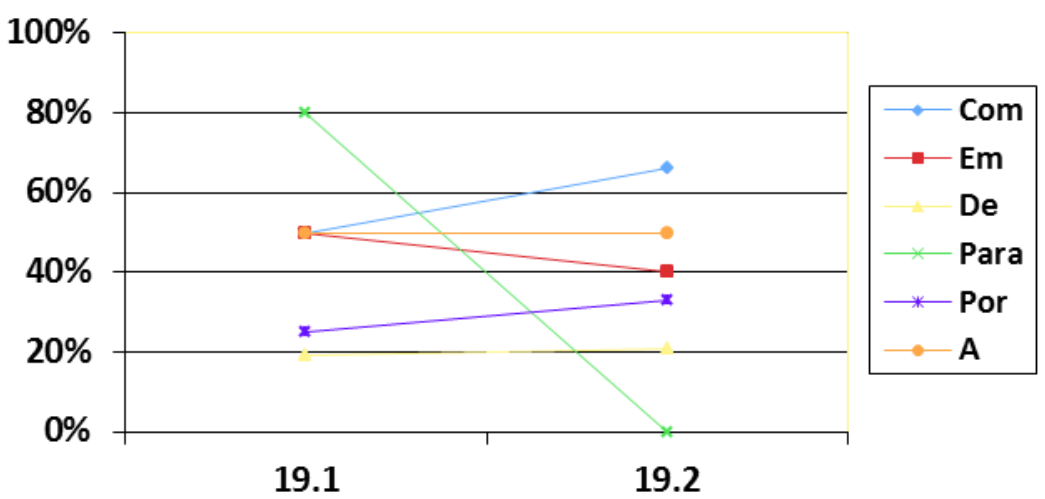

Gráfico 4.12: Presença do determinante diante dos diferentes tipos de preposição por período

\footnotetext{
${ }^{95}$ A preposição para desfavorece consideravelmente o uso do determinante, mas devemos considerar que o número de ocorrências (6) é muito baixo para se concluir algo. Precisaria de um corpus maior de investigação.
} 


\begin{tabular}{|c|l|c|c|}
\hline Preposição & & $\begin{array}{c}\mathbf{1 9 . 1} \\
\text { Frequência }\end{array}$ & $\begin{array}{c}\mathbf{1 9 . 2} \\
\text { Frequência }\end{array}$ \\
\hline \multirow{2}{*}{ COM } & Ausência do determinante & $5 / 10(50 \%)$ & $8 / 18(44 \%)$ \\
\cline { 2 - 4 } & Presença do determinante & $5 / 10(50 \%)$ & $10 / 18(66 \%)$ \\
\hline \multirow{2}{*}{ EM } & Ausência do determinante & $4 / 8(50 \%)$ & $9 / 15(60 \%)$ \\
\cline { 2 - 4 } & Presença do determinante & $4 / 8(50 \%)$ & $6 / 15(40 \%)$ \\
\hline \multirow{2}{*}{ DE } & Ausência do determinante & $22 / 27(81 \%)$ & $45 / 57(79 \%)$ \\
\cline { 2 - 4 } & Presença do determinante & $5 / 27(19 \%)$ & $12 / 57(21 \%)$ \\
\hline \multirow{2}{*}{ PARA } & Ausência do determinante & $1 / 5(20 \%)$ & $1 / 1(100 \%)$ \\
\cline { 2 - 4 } & Presença do determinante & $4 / 5(80 \%)$ & $0 / 1(0 \%)$ \\
\hline \multirow{2}{*}{ POR } & Ausência do determinante & $6 / 8(75 \%)$ & $4 / 6(67 \%)$ \\
\cline { 2 - 4 } & Presença do determinante & $2 / 8(25 \%)$ & $2 / 6(33 \%)$ \\
\hline \multirow{2}{*}{$\mathbf{A}$} & Ausência do determinante & $8 / 16(50 \%)$ & $17 / 34(50 \%)$ \\
\cline { 2 - 4 } & Presença do determinante & $8 / 16(50 \%)$ & $17 / 34(50 \%)$ \\
\hline
\end{tabular}

Tabela 4.9: Presença do determinante diante dos diferentes tipos de preposição por período

\subsubsection{A pessoa pronominal}

Como se sabe, muito estudos têm mostrado que a inserção de você/vocês no sistema dos pronomes pessoais, substituindo tu e vós, altera os usos do possessivo seu, levando à perda da distinção entre segunda e terceira pessoas na expressão do pronome possessivo (cf. Silva (1982, 1991, 1996); Perini (1985); Cerqueira (1993)). No entanto, na fala formal e na variedade escrita em diferentes tipos de textos, o possessivo seu é favorecido como forma anafórica na retomada do antecedente referencial de terceira pessoa.

Os nossos dados corroboram os estudos acima, uma vez que o percentual encontrado é de apenas $6 \%$ (22/365) de ocorrências do possessivo seu/sua usado para se remeter a segunda pessoa e 94\% (323/365) remetendo-se a terceira. São nos contextos de cartas de leitores enviadas a redatores que a maioria das ocorrências de segunda pessoa acontece. Verificamos o panorama geral de ocorrências na tabela 4.10 abaixo:

\begin{tabular}{|c|c|}
\hline Pessoa & Número de Ocorrências \\
\hline $\mathbf{3 a}$ & $323 / 365(94 \%)$ \\
\hline $\mathbf{2 a}$ & $22 / 365(6 \%)$ \\
\hline
\end{tabular}

Tabela 4.10: Número de ocorrências dos possessivos de segunda e terceira pessoas 
Ao analisarmos o século XIX como um todo, em 61\% (209/343) das ocorrências de seu/sua como terceira pessoa o determinante é morfofonologicamente nulo e em $39 \%$ dos casos, 134/343, o determinante é lexical. Para as ocorrências de seu/sua retomando uma referência de segunda pessoa, ocorre o oposto: $27 \%$ (6/22) das ocorrências há ausência de determinante, enquanto em 73\% (16/22) há presença (cf. gráfico 4.13 e tabela 4.11).

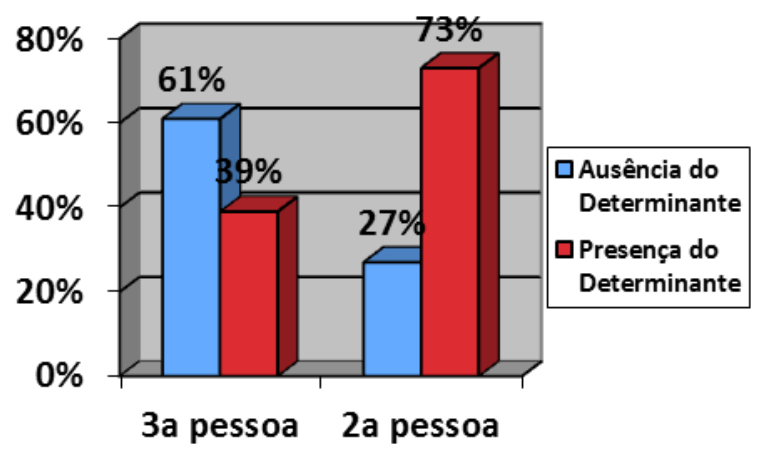

Gráfico 4.13: Frequência do determinante diante dos possessivos de terceira e segunda pessoas

Como é possível notar na tabela 4.11, o programa computacional GoldVarb selecionou o fator "tipo de pessoa" como altamente significativo para a análise, gerando, inclusive pesos relativos: 0,529 para a não realização do determinante diante do DP possessivo com referente de terceira pessoa e 0,139 como segunda. Isso significa que o possessivo de terceira pessoa desfavorece ligeiramente o não-uso do artigo, enquanto o possessivo de segunda pessoa comporta-se de forma consideravelmente contrária, favorecendo o não-uso do artigo.

Os resultados de frequência mostram que, nos contextos de terceira pessoa, a ausência do determinante é maior. No entanto, em DPs possessivos retomando antecedentes de segunda pessoa, principalmente, é notável o favorecimento do uso do determinante.

\begin{tabular}{|c|c|c|c|}
\hline Pessoa & $\begin{array}{c}\text { Ausência do } \\
\text { determinante }\end{array}$ & $\begin{array}{c}\text { Presença do } \\
\text { determinante }\end{array}$ & $\begin{array}{c}\text { Peso Relativo } \\
\text { (de não realização) }\end{array}$ \\
\hline $\mathbf{3}^{\text {a }}$ pessoa & $209 / 343(61 \%)$ & $134 / 343(39 \%)$ & 0,529 \\
\hline $\mathbf{2}^{\mathbf{a}}$ pessoa & $6 / 22(27 \%)$ & $16 / 22(73 \%)$ & 0,139 \\
\hline
\end{tabular}

Log likelihood $=-220,701$ Significance $=0,005$

Tabela 4.11: Frequência do determinante diante dos possessivos de terceira e segunda pessoas

Esses dados apresentados se referem ao século XIX como um todo. Entretanto, é importante analisarmos os dados separados por período. Nos gráfico 4.14, 4.15 e tabela 4.12 apresentamos a frequência do determinante diante dos possessivos de terceira pessoa apenas. 


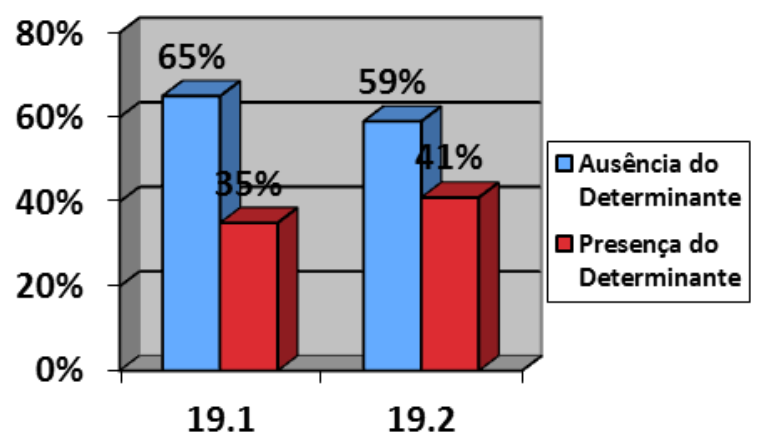

Gráfico 4.14: Ausência x Presença do determinante diante do possessivo de $3^{\mathrm{a}}$ pessoa

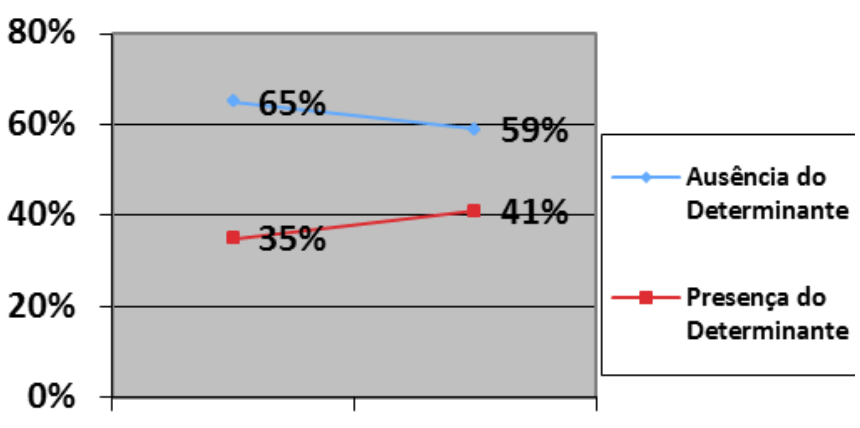

$19.1 \quad 19.2$

Gráfico 4.15: Ausência x Presença do determinante diante do possessivo de $3^{\mathrm{a}}$ pessoa

\begin{tabular}{|c|c|c|}
\hline Possessivos de $3^{\text {a }}$ pessoa & $\begin{array}{c}\mathbf{1 9 . 1} \\
\text { Frequência }\end{array}$ & $\begin{array}{c}\mathbf{1 9 . 2} \\
\text { Frequência }\end{array}$ \\
\hline Ausência do determinante & $74 / 114(65 \%)$ & $135 / 229(59 \%)$ \\
\hline Presença do determinante & $40 / 114(35 \%)$ & $94 / 229(41 \%)$ \\
\hline Total & $114 / 343(33 \%)$ & $229 / 343(66 \%)$ \\
\hline
\end{tabular}

Tabela 4.12: Frequência do determinante diante dos possessivos de terceira pessoa

Sobre o uso do determinante diante do possessivo de terceira pessoa em nossos corpora, é possível afirmar que há uma ligeira mudança em direção à realização do artigo entre a primeira metade e a segunda metade do século XIX, sem diferenças significativas (apenas de 6\%). Para os possessivos de segunda pessoa, nota-se que o próprio uso da pessoa pronominal é pequeno (22/243 (6\%)) e, quando usado, a frequência dos determinantes é irregular, mas com tendência à ausência, como demonstram gráficos 4.16, 4.17 e tabela 4.13 abaixo. 


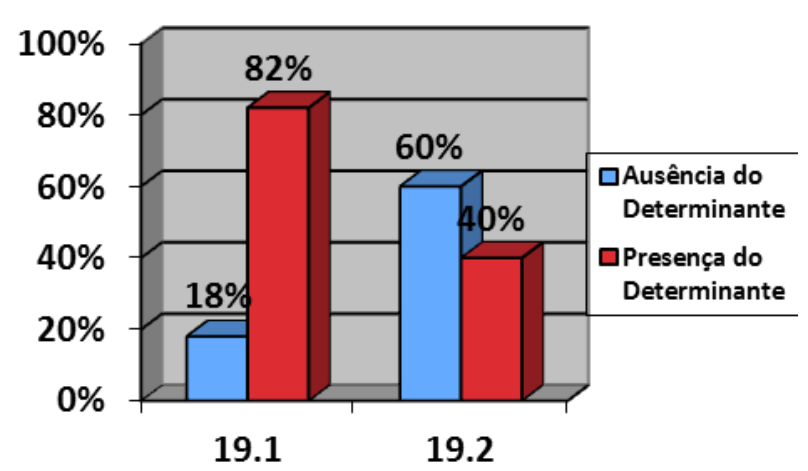

Gráfico 4.16: Ausência x Presença do determinante diante do possessivo de $2^{\mathrm{a}}$ pessoa

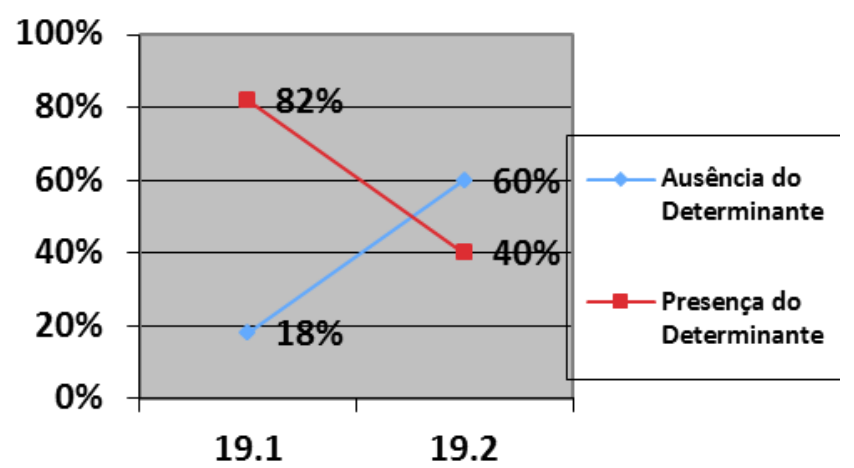

Gráfico 4.17: Ausência x Presença do determinante diante do possessivo de $2^{\mathrm{a}}$ pessoa

\begin{tabular}{|c|c|c|}
\hline Possessivos de $\mathbf{2}^{\mathbf{a}}$ pessoa & $\begin{array}{c}\mathbf{1 9 . 1} \\
\text { Frequência }\end{array}$ & $\begin{array}{c}\mathbf{1 9 . 2} \\
\text { Frequência }\end{array}$ \\
\hline Ausência do determinante & $3 / 17(18 \%)$ & $3 / 5(60 \%)$ \\
\hline Presença do determinante & $14 / 17(82 \%)$ & $2 / 5(40 \%)$ \\
\hline Total & $17 / 22(77 \%)$ & $5 / 22(23 \%)$ \\
\hline
\end{tabular}

Tabela 4.13: Frequência do determinante diante dos possessivos de segunda pessoa

É interessante notar que estudos como o de Silva (1982) sobre o PE e o PB já relatavam sobre a notável diferença entre o uso do determinante diante do possessivo seu/seu de terceira e de segunda pessoa. Segundo a autora, o uso em terceira pessoa desfavorece o uso do artigo mais que o de segunda (16\% de presença contra 55\%, respectivamente). Em nossa pesquisa, os resultados corroboram os de Silva (1982), uma vez que temos 39\% de presença do determinante na terceira pessoa e $73 \%$ na segunda.

Esse ponto vale a pena ser valorizado em pesquisas posteriores, uma vez que enquanto o possessivo de terceira pessoa desfavorece o uso do determinante de forma quase neutra, o possessivo de segunda pessoa o favorece decisivamente. 


\subsubsection{Tipos de verbos}

Para uma melhor análise dos dados, observar a tipologia do verbo na sentença é de fundamental importância. Foi considerada a tipologia dos verbos conforme apresentada em Berlinck (1996), na qual esses são semanticamente divididos em três tipos:

(i) verbos dinâmicos que expressam transferência ou movimento: correr, entregar, mudar, trazer, levar, andar, cozinhar, abrir, fechar, jogar, pular, comer, beber, dar, mover, fazer, devolver, roubar, tirar, suprimir, colocar, pôr, etc.

(ii) verbos dinâmicos que não expressam transferência ou movimento: beijar, lavar, pentear, operar, acariciar, apalpar, arruinar, articular, cobrir, destruir, esfregar, estragar, examinar, ferir, guardar, limpar, massagear, modificar, mutilar, operar, organizar, pegar, pentear, polir, rasgar, remendar, salvar, secar (o cabelo), sujar, tingir, transformar, trocar, etc.

(iii) verbos estativos: admirar, invejar, analisar, avaliar, conhecer, desejar, entender, esperar, imaginar, observar, ouvir, provocar, querer, reconhecer, satisfazer, segurar, etc.

Dentre as 365 ocorrências, 238/365 (66\%) contemplam verbos estativos, 65/365 $(17,5 \%)$ verbos dinâmicos de movimento e transferência e 62/365 (16,5\%) verbos dinâmicos sem movimento e transferência, como mostram o gráfico 4.18 e tabela 4.14 :

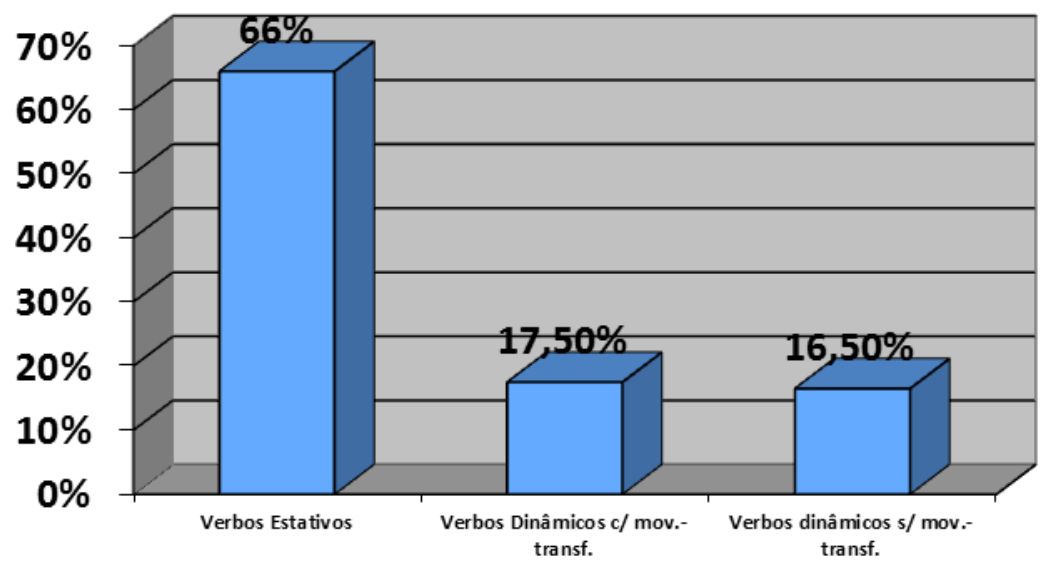

口Percentual de Ocorrências 


\begin{tabular}{|c|c|}
\hline Tipos de Verbos & Número de Ocorrências \\
\hline Estativos & $238 / 365(66 \%)$ \\
\hline $\begin{array}{c}\text { Dinâmicos com } \\
\text { movimento/transferência }\end{array}$ & $65 / 365(17,5 \%)$ \\
\hline $\begin{array}{c}\text { Dinâmicos sem } \\
\text { movimento/transferência }\end{array}$ & $62 / 365(16,5 \%)$ \\
\hline
\end{tabular}

Tabela 4.14: Número de ocorrências a partir dos tipos de verbos

Ao analisarmos o uso do determinante nos sintagmas nominais possessivos e os diferentes tipos de verbos na sentença, chegamos ao resultado para ausência do determinante de: $56 \%$ (131/238) para os verbos estativos (PR: 0,443), 76\% (49/65) para os verbos dinâmicos com movimento/transferência (PR: 0,719) e 57\% (35/62) para os verbos dinâmicos sem movimento/transferência (PR: 0,474) - cf. gráfico 4.19 e tabela 4.15 .
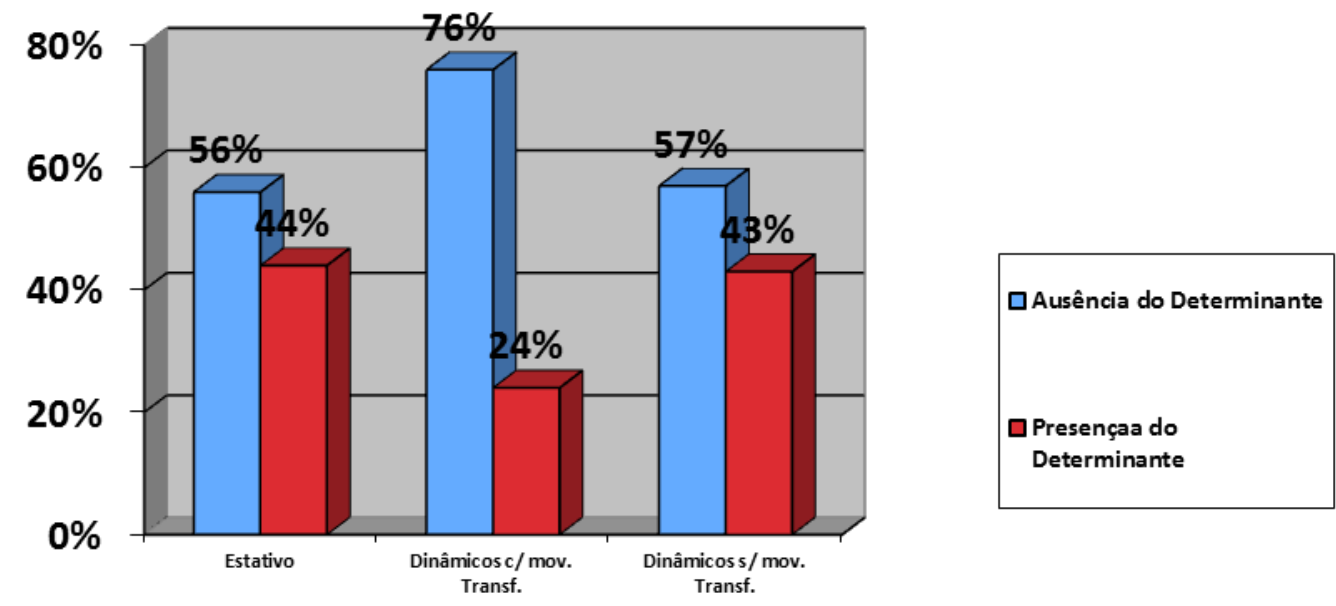

Gráfico 4.19: Percentual de frequência dos determinantes a partir dos tipos de verbos

\begin{tabular}{|c|c|c|c|}
\hline Tipo de Verbo & $\begin{array}{c}\text { Ausência do } \\
\text { determinante }\end{array}$ & $\begin{array}{c}\text { Presença do } \\
\text { determinante }\end{array}$ & $\begin{array}{c}\text { Peso Relativo } \\
\text { (de não realização) }\end{array}$ \\
\hline Estativos & $131 / 238(56 \%)$ & $107 / 238(44 \%)$ & 0,443 \\
\hline $\begin{array}{c}\text { Dinâmicos com } \\
\text { movimento/transferência }\end{array}$ & $49 / 65(76 \%)$ & $16 / 65(24 \%)$ & 0,719 \\
\hline $\begin{array}{c}\text { Dinâmicos sem } \\
\text { movimento/transferência }\end{array}$ & $35 / 62(57 \%)$ & $27 / 62(43 \%)$ & 0,474 \\
\hline
\end{tabular}

Log likelihood $=-220,701$ Significance $=0,005$

Tabela 4.15: Frequência dos determinantes a partir dos tipos de verbos 
As frequências do uso do artigo diante do possessivo quando os verbos são estativos e dinâmicos sem movimento e transferência mostram uma variação no uso. Quando verificamos seu percentual (56\% para os estativos e 57\% para os dinâmicos sem movimento/transferência) percebemos que esses tipos de verbos favorecem ligeiramente a presença do artigo.

Isso se comprova no peso relativo fornecido pelo programa computacional: 0,443 para os verbos estativos e 0,474 para os verbos dinâmicos sem movimento ou transferência. Ou seja, os dados aqui significam que esses tipos de verbos desfavorecem $(<50)$ a não realização do artigo.

Os verbos dinâmicos com movimento ou transferência, por sua vez, apresentam um percentual de ausência do determinante de $76 \%$ - um percentual considerado representativo para o apagamento do artigo. Quanto ao peso relativo, os verbos dinâmicos com movimento ou transferência favorecem muito a não realização do artigo: 0,719 de peso relativo.

Logo, quando analisamos em um panorama geral a frequência do determinante (gráfico 4.17 e tabela 4.12), percebemos que os verbos dinâmicos com movimento e transferência apresentam um favorecimento considerável de ausência do artigo ( $P R=0,719)$. Os verbos estativos e dinâmicos sem movimento ou transferência não nos permite fazer uma afirmação segura a respeito, uma vez que apresentam $P R=0,443$ e 0,474, respectivamente.

A seguir, podemos verificar essa frequência cronológica dos verbos, a partir da primeira e da segunda metades do século XIX, obedecendo às tipologias acima mencionadas. Os gráficos 4.18, 4.19 e tabela 4.13 representam os dados dos verbos estativos, que apresentam um aumento considerável na ausência do determinante (de 10\% $=48 \%$ para $58 \%)$.

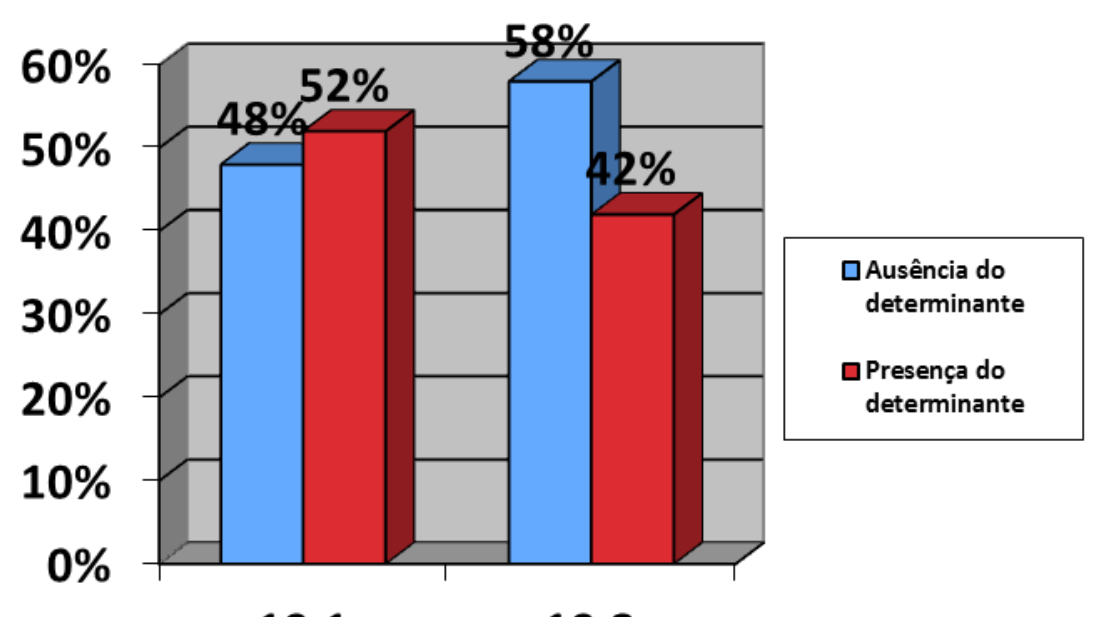

$19.1 \quad 19.2$ 


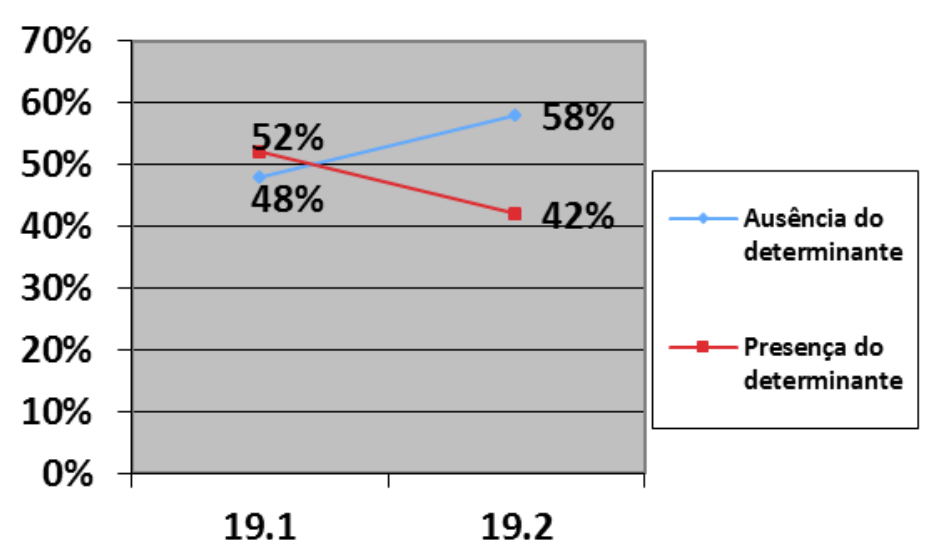

Gráfico 4.21: Frequência dos determinantes em sentenças com verbos estativos

\begin{tabular}{|c|c|c|}
\hline Verbos Estativos & $\begin{array}{c}\mathbf{1 9 . 1} \\
\text { Frequência }\end{array}$ & $\begin{array}{c}\mathbf{1 9 . 2} \\
\text { Frequência }\end{array}$ \\
\hline Ausência do determinante & $38 / 79(48 \%)$ & $93 / 159(58 \%)$ \\
\hline Presença do determinante & $41 / 79(52 \%)$ & $66 / 159(42 \%)$ \\
\hline Total & $79 / 238(77 \%)$ & $159 / 238(23 \%)$ \\
\hline
\end{tabular}

Tabela 4.16: Frequência dos determinantes em sentenças com verbos estativos

Os gráficos 4.20, 4.21 e tabela 4.16 representam os dados dos verbos dinâmicos com movimento ou transferência, que mantêm um alto percentual de ausência do determinante nas duas metades de século ( $76 \%$ para a primeira e $75 \%$ para a segunda).

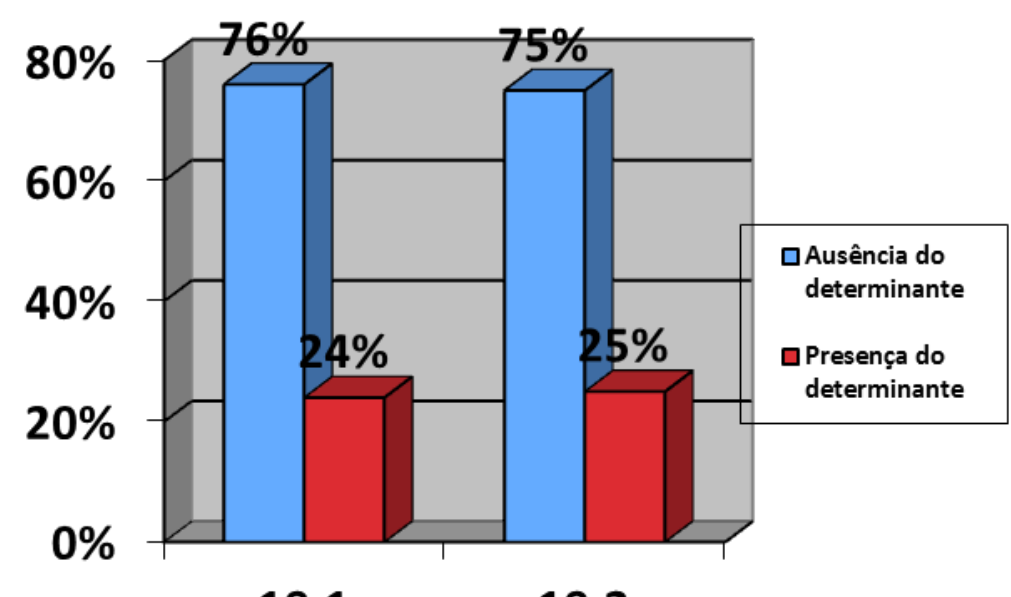

$19.1 \quad 19.2$

Gráfico 4.22: Percentual de frequência dos determinantes em sentenças com verbos dinâmicos com movimento/transferência 


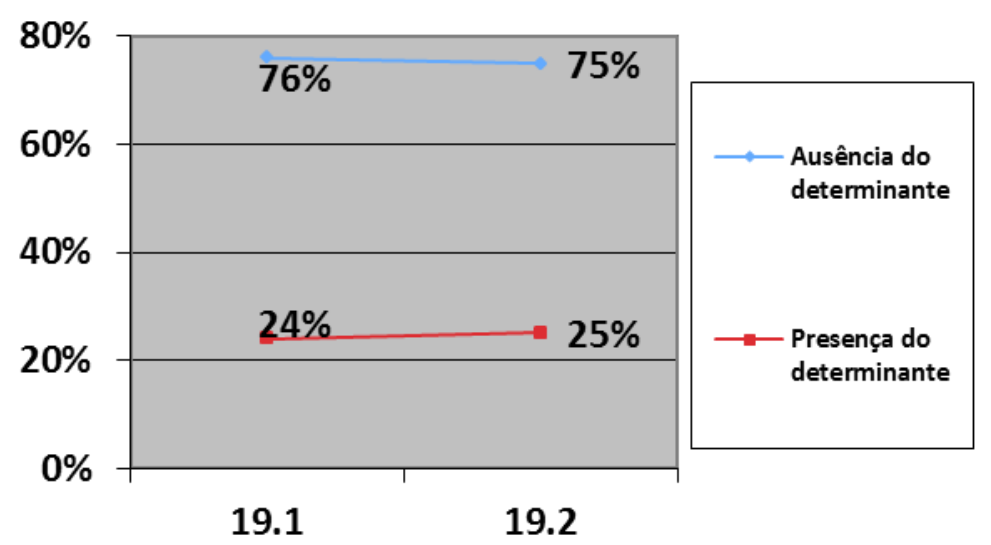

Gráfico 4.23: Percentual de frequência dos determinantes em sentenças com verbos dinâmicos com movimento/transferência

\begin{tabular}{|c|c|c|}
\hline $\begin{array}{c}\text { Verbos Dinâmicos com } \\
\text { movimento/transferência }\end{array}$ & $\begin{array}{c}\mathbf{1 9 . 1} \\
\text { Frequência }\end{array}$ & $\begin{array}{c}\mathbf{1 9 . 2} \\
\text { Frequência }\end{array}$ \\
\hline Ausência do determinante & $22 / 29(76 \%)$ & $27 / 36(75 \%)$ \\
\hline Presença do determinante & $7 / 29(24 \%)$ & $9 / 36(25 \%)$ \\
\hline Total & $29 / 65(45 \%)$ & $36 / 65(55 \%)$ \\
\hline
\end{tabular}

Tabela 4.17: Frequência dos determinantes em sentenças com verbos dinâmicos com movimento/transferência

E os verbos dinâmicos sem movimento ou transferência apresentam percentuais em disparidades entre as duas metades: na primeira, a ausência do determinante é de $74 \%$, na segunda, a ausência é de $46 \%$ (tabela 4.1 e gráficos 4.22 e 4.23).

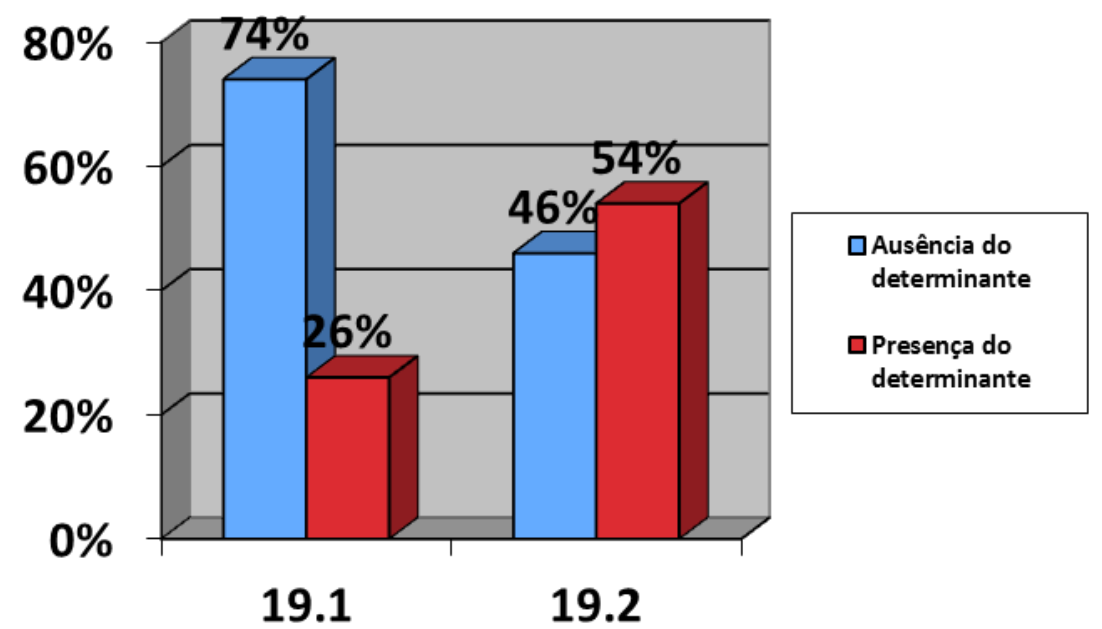

Gráfico 4.24: Percentual de frequência dos determinantes em sentenças com verbos dinâmicos sem movimento/transferência 


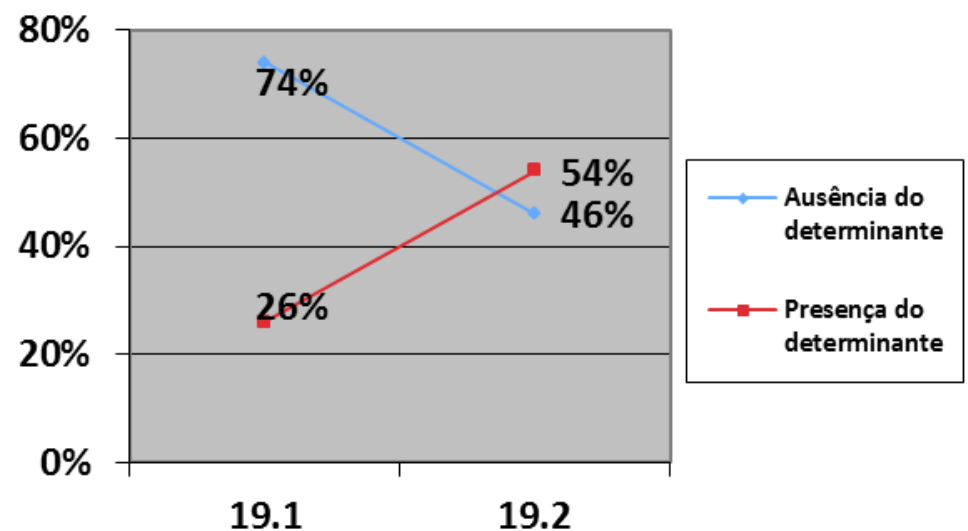

Gráfico 4.25: Frequência dos determinantes em sentenças com verbos dinâmicos sem movimento/transferência

\begin{tabular}{|c|c|c|}
\hline $\begin{array}{c}\text { Verbos Dinâmicos sem } \\
\text { movimento/transferência }\end{array}$ & $\begin{array}{c}\mathbf{1 9 . 1} \\
\text { Frequência }\end{array}$ & $\begin{array}{c}\mathbf{1 9 . 2} \\
\text { Frequência }\end{array}$ \\
\hline Ausência do determinante & $17 / 23(74 \%)$ & $18 / 39(46 \%)$ \\
\hline Presença do determinante & $6 / 23(26 \%)$ & $21 / 39(52 \%)$ \\
\hline Total & $23 / 62(37 \%)$ & $39 / 62(63 \%)$ \\
\hline
\end{tabular}

Tabela 4.18: Frequência dos determinantes em sentenças com verbos dinâmicos sem movimento/transferência

Se analisarmos as tabelas 4.16, 4.17 e 4.18 e os gráficos 4.20, 4.21, 4.22, 4.23, 4.24 e 4.25, notamos diferenças relevantes da primeira metade para a segunda metade do século XIX. É possível notar que, de acordo com os dados, verbos dinâmicos com movimento ou transferência de fato favorecem a ausência do determinante. Isso se deve ao fato de que este tipo de verbo licencia um objeto DP, o qual é normalmente interpretado como tema, ou como o indivíduo que se move, ou sofre a mudança. No contexto, essa mudança já está inserida, não tendo a necessidade de interpretá-la com uma definição maior que o próprio possessivo já sugere.

\subsubsection{Função sintática do sintagma}

Os sintagmas nominais possessivos podem ter três funções sintáticas na sentença: sujeito, oblíquo e objeto direto. O sujeito, preposto ao verbo; o oblíquo, complemento/adjunto preposicionado; e objeto direto, complemento não preposicionado. Das 365 ocorrências, 136 (37\%) são objetos diretos, 206 (57\%) oblíquos e 23 (6\%) sujeitos: 


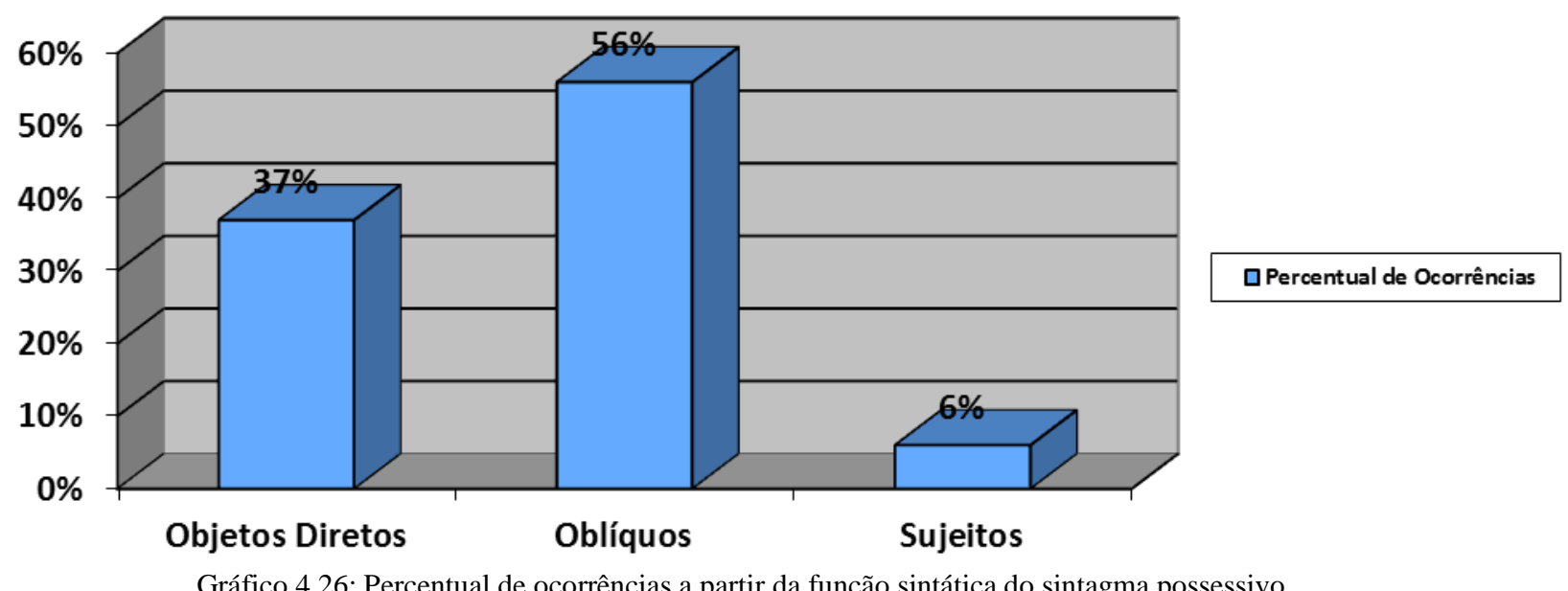

Gráfico 4.26: Percentual de ocorrências a partir da função sintática do sintagma possessivo

\begin{tabular}{|c|c|}
\hline Função Sintática & Número de Ocorrências \\
\hline Objetos Diretos & $136 / 365(37 \%)$ \\
\hline Oblíquos & $206 / 365(56 \%)$ \\
\hline Sujeitos & $23 / 365(6 \%)$ \\
\hline
\end{tabular}

Tabela 4.19: Número de ocorrências a partir da função sintática do sintagma possessivo

Após verificar a frequência de ocorrências das funções (gráfico 4.26 e tabela 4.19), é possível distinguir dentre essas ocorrências e suas funções as quais favorecem o uso do artigo ou não. $\mathrm{Na}$ tabela 4.20 e gráfico 4.27 abaixo, contrapomos as três funções sintáticas considerando a presença e a ausência do artigo em todo o século XIX.

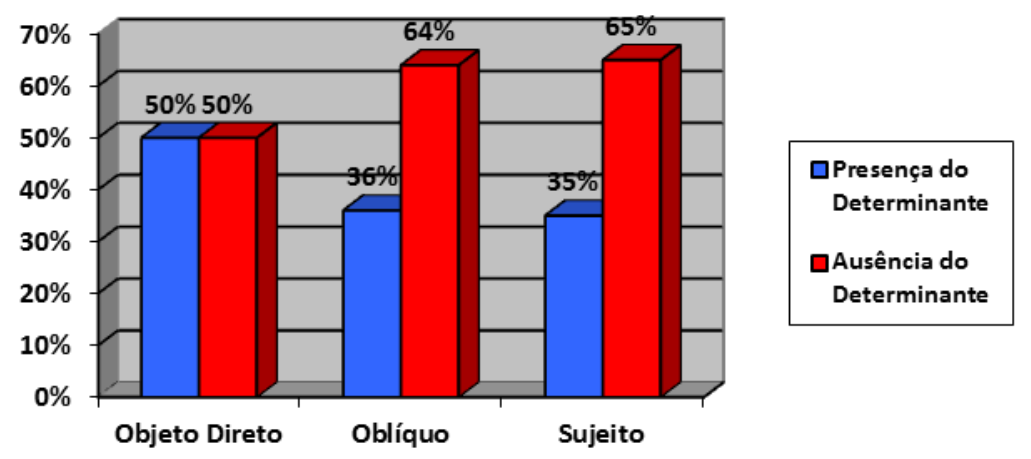

Gráfico 4.27: Presença x ausência do artigo a partir da função sintática do sintagma possessivo 


\begin{tabular}{|c|c|c|}
\hline Tipo de Verbo & Frequência com Determinante & Frequência sem Determinante \\
\hline Objeto Direto & $68 / 136(50 \%)$ & $68 / 136(50 \%)$ \\
\hline Oblíquo & $74 / 206(36 \%)$ & $132 / 206(64 \%)$ \\
\hline Sujeito & $8 / 23(35 \%)$ & $15 / 23(65 \%)$ \\
\hline
\end{tabular}

Tabela 4.20: Presença $\mathrm{x}$ ausência do artigo a partir da função sintática do sintagma possessivo

De acordo com os números acima, as funções sintáticas de oblíquo e sujeito não favorecem o uso do artigo ( $35 \%$ e $34 \%$ de frequência com o determinante, respectivamente). A função de objeto direto, por sua vez, prevalece neutra no quesito (50\% de frequência com o determinante).

Também é possível analisar os períodos cronologicamente, considerando as duas metades do século XIX. Quanto ao objeto direto, temos 52\% (24/46) de ausência do determinante na primeira metade do século XIX e 49\% (44/90) na segunda - uma diminuição percentual de apenas 3\%, cf. gráficos 4.28, 4.29 e tabela 4.21 .

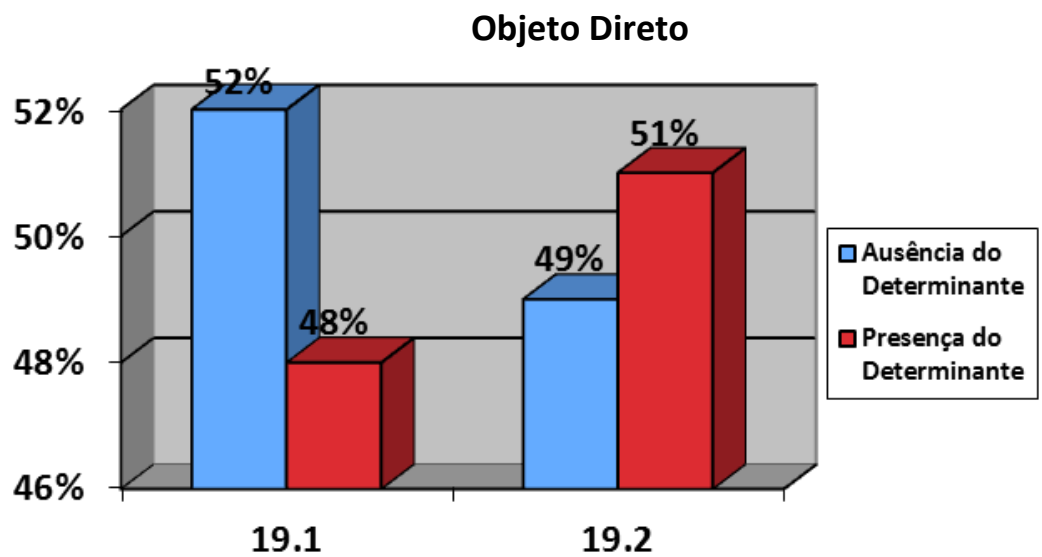

Gráfico 4.28: Frequência do determinante diante do objeto direto 


\section{Objeto Direto}

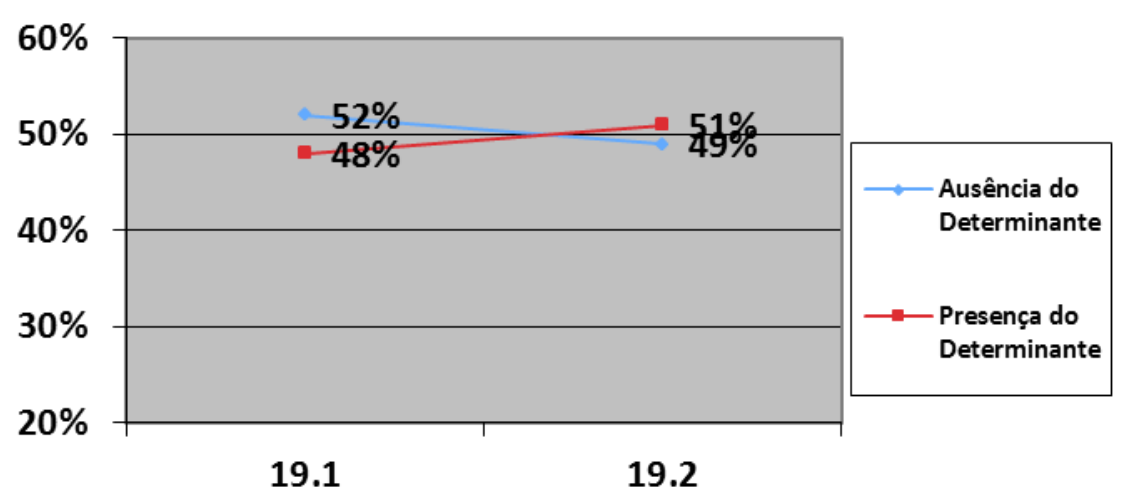

Gráfico 4.29: Frequência do determinante diante do objeto direto

\begin{tabular}{|c|c|c|}
\hline Objeto Direto & $\begin{array}{c}\mathbf{1 9 . 1} \\
\text { Frequência }\end{array}$ & $\begin{array}{c}\mathbf{1 9 . 2} \\
\text { Frequência }\end{array}$ \\
\hline Ausência do determinante & $24 / 46(52 \%)$ & $44 / 90(49 \%)$ \\
\hline Presença do determinante & $22 / 46(48 \%)$ & $46 / 90(51 \%)$ \\
\hline Total & $46 / 136(34 \%)$ & $90 / 136(66 \%)$ \\
\hline
\end{tabular}

Tabela 4.21: Frequência do determinante em objetos diretos

Quanto ao oblíquo, temos 62\% (46/74) de ausência do determinante na primeira metade do século XIX e 65\% (86/132) na segunda - um aumento percentual de apenas 3\%, cf. gráficos 4.30, 4.31 e tabela 4.22 .

\section{Oblíquo}

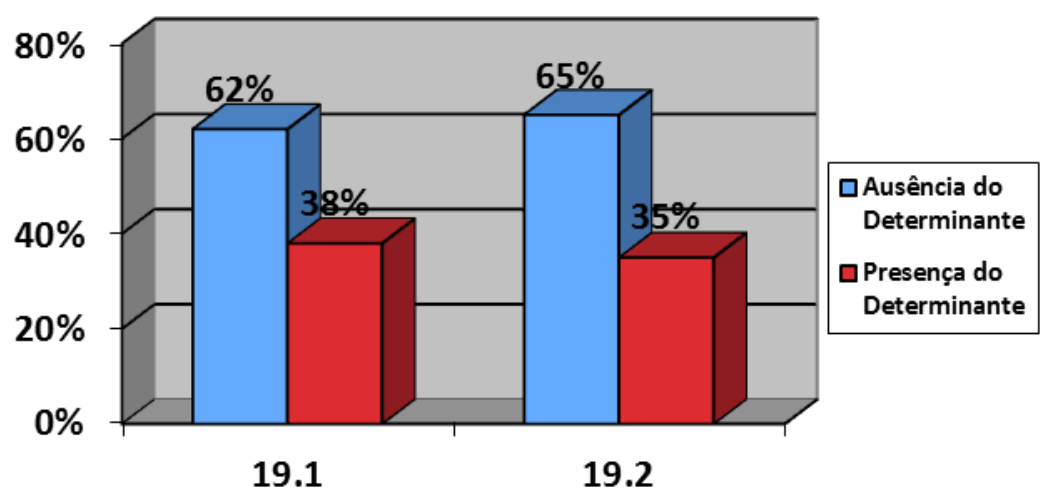

Gráfico 4.30: Frequência do determinante diante do oblíquo 
Oblíquo

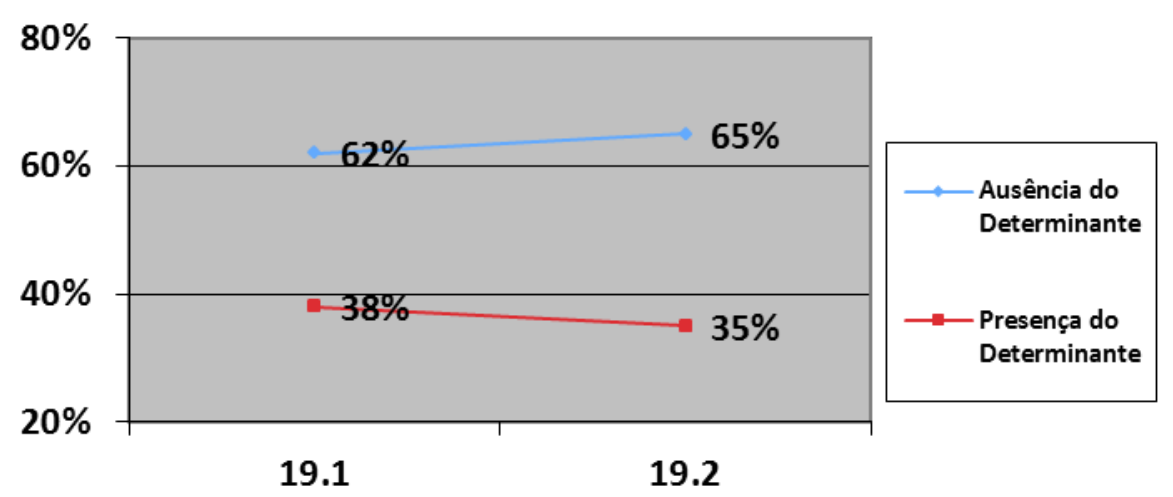

Gráfico 4.31: Frequência do determinante diante do oblíquo

\begin{tabular}{|c|c|c|}
\hline Oblíquo & $\begin{array}{c}\mathbf{1 9 . 1} \\
\text { Frequência }\end{array}$ & $\begin{array}{c}\mathbf{1 9 . 2} \\
\text { Frequência }\end{array}$ \\
\hline Ausência do determinante & $46 / 74(62 \%)$ & $86 / 132(65 \%)$ \\
\hline Presença do determinante & $28 / 74(38 \%)$ & $46 / 132(35 \%)$ \\
\hline Total & $74 / 206(36 \%)$ & $132 / 206(64 \%)$ \\
\hline \multicolumn{2}{|c|}{ Tabela 4.22: Frequência do determinante do oblíquo } \\
\hline
\end{tabular}

Quanto ao sujeito, temos 64\% (7/11) de ausência do determinante na primeira metade do século XIX e 79\% (8/12) na segunda - um aumento percentual de 15\%, cf. gráficos 4.32 , 4.33 e tabela 4.23 . 


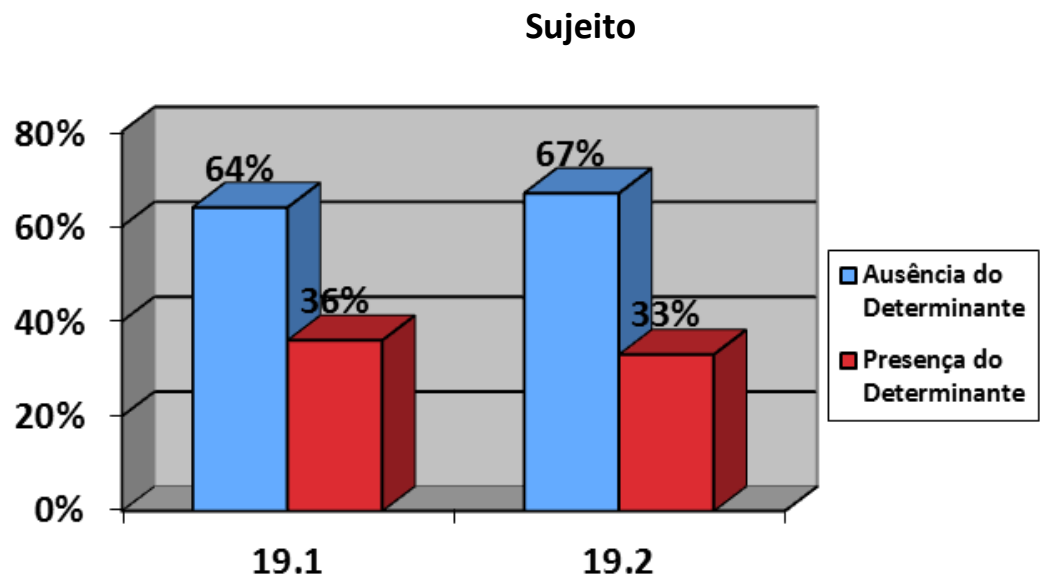

Gráfico 4.32: Frequência do determinante diante do sujeito

\section{Sujeito}

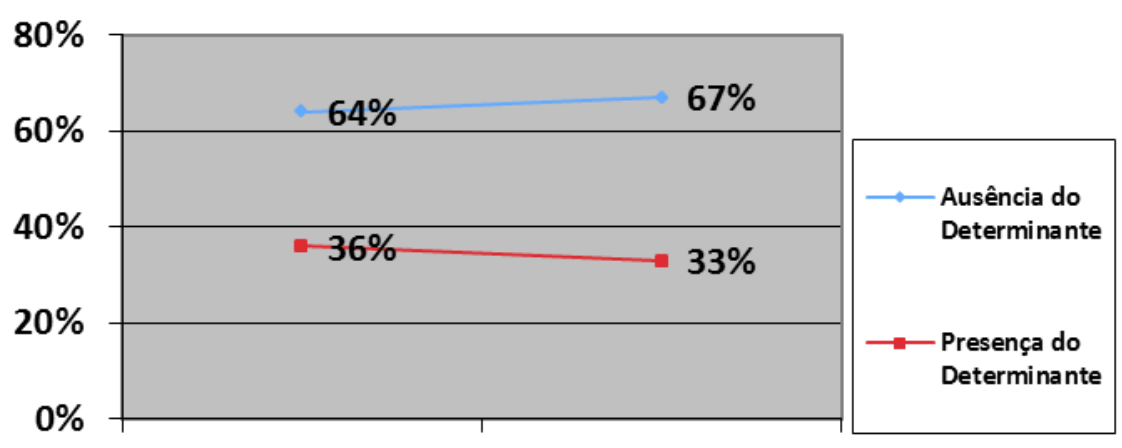

19.1

19.2

Gráfico 4.33: Frequência do determinante diante do sujeito

\begin{tabular}{|c|c|c|}
\hline Sujeito & $\mathbf{1 9 . 1}$ & $\begin{array}{c}\mathbf{1 9 . 2} \\
\text { Frequência }\end{array}$ \\
\hline Ausência do determinante & $7 / 11(64 \%)$ & $8 / 12(79 \%)$ \\
\hline Presença do determinante & $4 / 11(36 \%)$ & $4 / 12(33 \%)$ \\
\hline Total & $11 / 23(48 \%)$ & $12 / 23(52 \%)$ \\
\hline
\end{tabular}

Tabela 4.23: Frequência do determinante diante do sujeito

De acordo com as frequências apresentadas, as funções sintáticas de oblíquo e sujeito não favorecem o uso do artigo (média de 64\% e 65\% de ausência, respectivamente). A função de objeto direto, por sua vez, prevalece neutra no quesito (média de 50\%). Ao longo do século XIX, as ocorrências não variam muito, diferenciando-se em no máximo 5\%. Logo, a análise 
desse fator traz indícios de uma ausência maior no determinante diante de sintagmas nominais possessivos quando esses ocupam a função sintática de oblíquo (com preposição, o que corrobora o item 4.4.2) e de sujeito (agente, causador e experienciador, que tem uma referência no contexto).

\subsubsection{Tipos de posse do sintagma}

No intuito de investigar os diferentes contextos que podem ou não favorecer o uso do artigo diante de sintagmas nominais possessivos no PB, examinamos também o tipo de posse do sintagma do possessivo. Essa posse se distingue entre alienável e inalienável. A posse alienável é a que pode ser atribuída a qualquer referente que esteja dentro do contexto, não necessariamente dentro da sentença. A posse inalienável, por sua vez, estabelece uma relação entre o referente/possuidor dentro da sentença, não podendo ser atribuída a posse a outro referente. Esta última pode ser dividida em três tipos: parte do corpo, parentesco e parte-todo, mas como as ocorrências são poucas para serem demonstradas em gráficos separados, apresentamos aqui a posse inalienável como um todo. A ocorrência dos diferentes tipos de posse pode ser analisada abaixo:

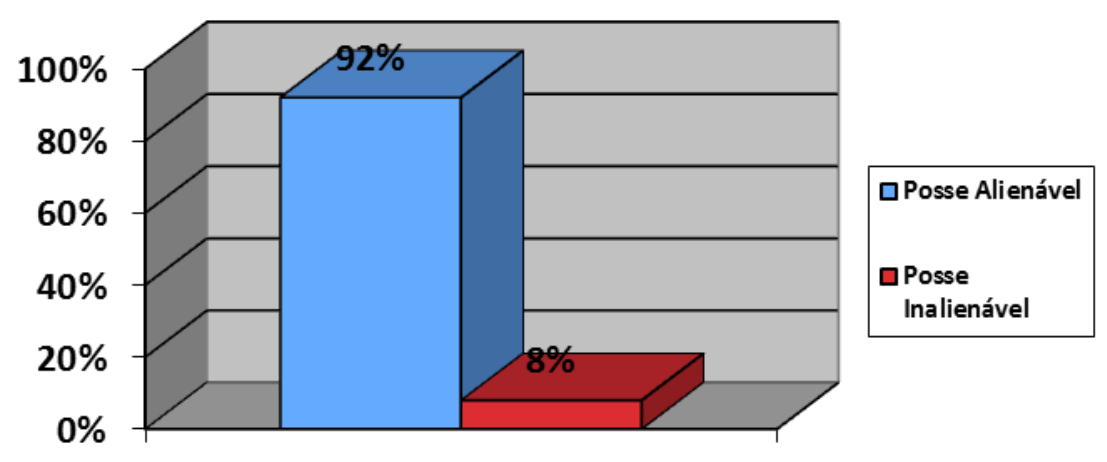

Gráfico 4.34: Número de ocorrências dos determinantes de acordo com os tipos de posse

\begin{tabular}{|c|c|}
\hline Tipo de Posse & Número de ocorrências \\
\hline Alienável & $336 / 365(92 \%)$ \\
\hline Inalienável & $29 / 365(8 \%)$ \\
\hline
\end{tabular}

Tabela 4.24: Número de ocorrências do corpus de acordo com os tipos de posse

Nota-se que grande maioria da posse presente nos corpura classifica-se como alienável $(92 \%, 336 / 365)$ e apenas $8 \%$ (29/365) como posse inalienável, conforme mostram a 
tabela 4.24 e o gráfico 4.34. Basta saber qual é o uso do determinante diante dos diferentes tipos de posse conforme os períodos.

Analisando a presença e a ausência do artigo em todo o século XIX considerando o tipo de posse, percebemos que a ausência do determinante prevalece nos dois tipos de posses, porém é ainda maior na posse inalienável (69\%) do que na posse alienável (59\%) - cf. gráfico 4.35 e tabela 4.25 .

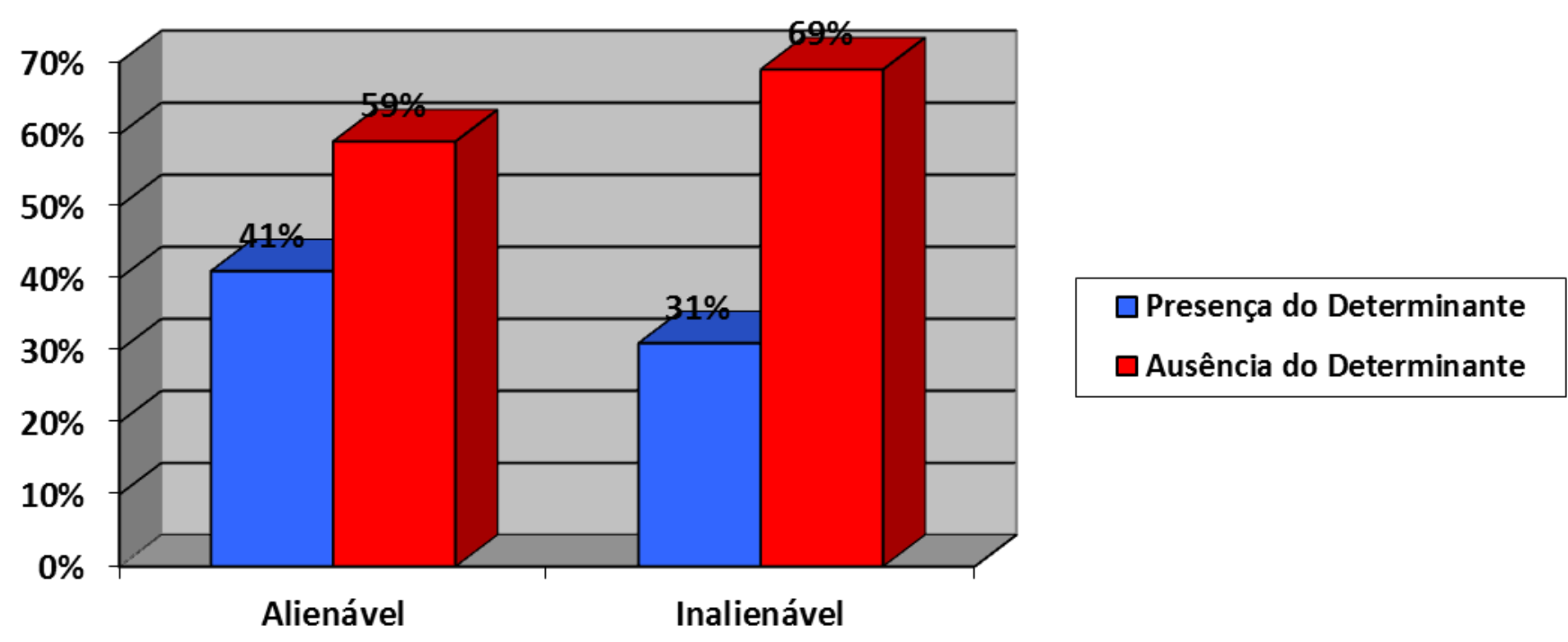

Gráfico 4.35: Presença x ausência dos determinantes de acordo com os tipos de posse

\begin{tabular}{|c|c|c|}
\hline Tipo de Posse & $\begin{array}{c}\text { Frequência com } \\
\text { Determinante }\end{array}$ & $\begin{array}{c}\text { Frequência sem } \\
\text { Determinante }\end{array}$ \\
\hline Alienável & $141 / 336(41 \%)$ & $195 / 336(59 \%)$ \\
\hline Inalienável & $9 / 29(31 \%)$ & $20 / 29(69 \%)$ \\
\hline
\end{tabular}

Tabela 4.25: Presença $\mathrm{x}$ ausência dos determinantes de acordo com os tipos de posse

Examinando os casos de posse alienável, grande maioria no corpus, verificamos um percentual de $56 \%$ de ausência do determinante para a primeira metade e 59\% para a segunda metade do século XIX - cf. gráficos 4.36, 4.37 e tabela 4.26. A escolha do uso do determinante está relacionada a outros fatores na sentença que determinam melhor a ausência ou presença do determinante (como preposição, pessoa pronominal, e outros apresentados nesta seção). 


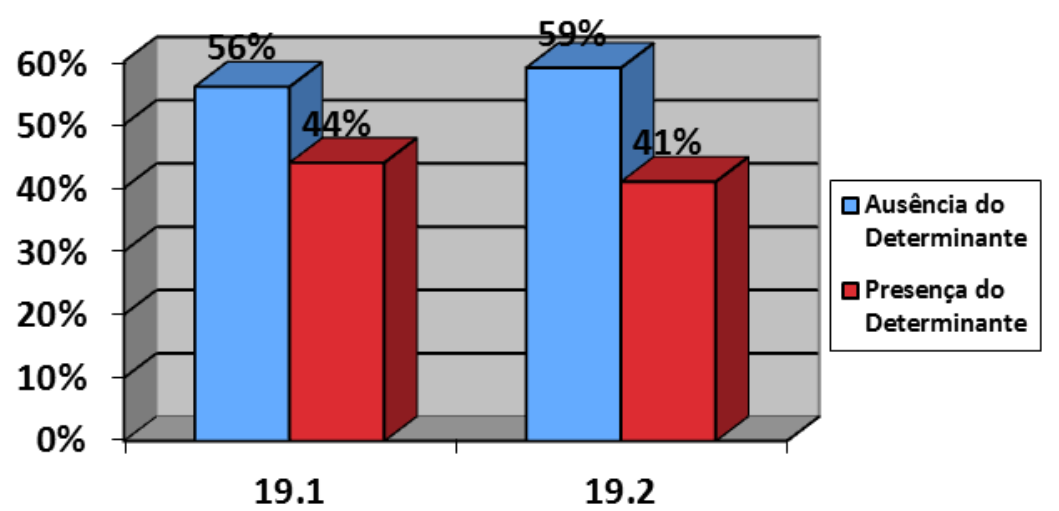

Gráfico 4.36: Frequência do determinante com posse Alienável

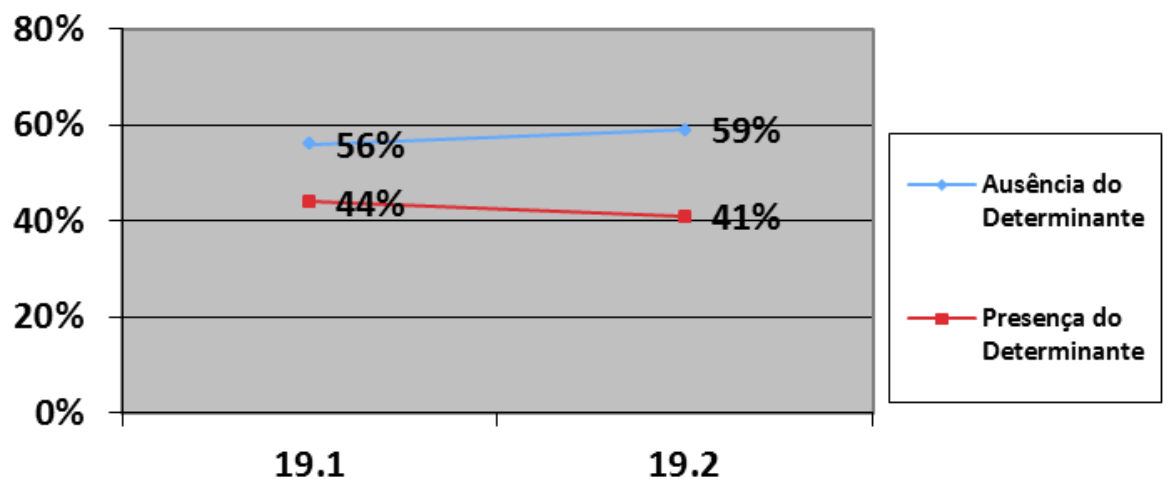

Gráfico 4.37: Frequência do determinante com posse Alienável

\begin{tabular}{|c|c|c|}
\hline Posse alienável & $\begin{array}{c}\mathbf{1 9 . 1} \\
\text { Frequência }\end{array}$ & $\begin{array}{c}\mathbf{1 9 . 2} \\
\text { Frequência }\end{array}$ \\
\hline Ausência do determinante & $67 / 119(56 \%)$ & $128 / 217(59 \%)$ \\
\hline Presença do determinante & $52 / 119(44 \%)$ & $89 / 217(41 \%)$ \\
\hline Total & $119 / 336(35 \%)$ & $217 / 336(65 \%)$ \\
\hline
\end{tabular}

Tabela 4.26: Frequência do determinante com posse Alienável

Ao nos depararmos com a posse inalienável, nossos dados mostram que, na primeira metade do século XIX, o contexto favoreceu $83 \%$ (10/12) a ausência do determinante. Na segunda metade, o contexto favoreceu 59\%. (10/17). De um período para o outro, o determinante aumentou em 14\% a sua frequência de ocorrências (cf. gráficos 4.38, 4.39 e tabela 4.27). 


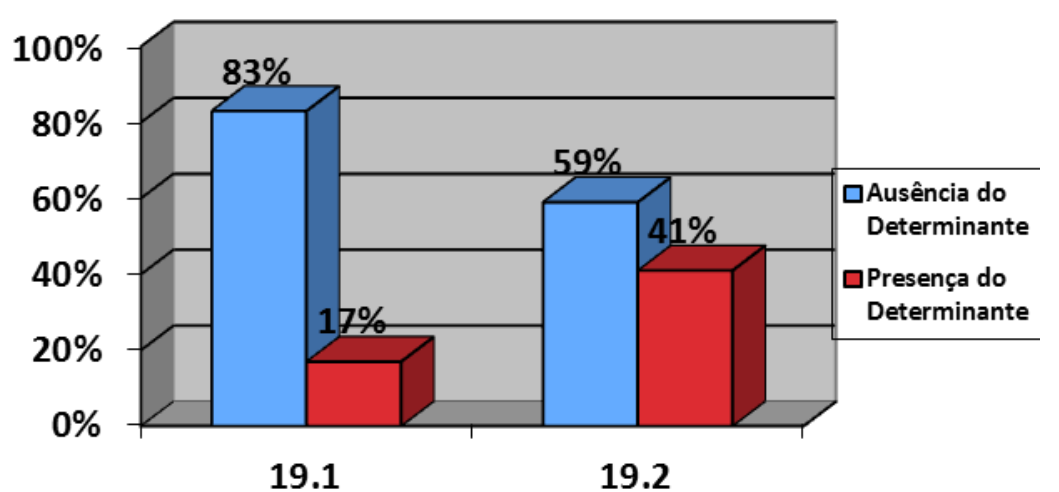

Gráfico 4.38: Frequência do determinante com posse Inalienável

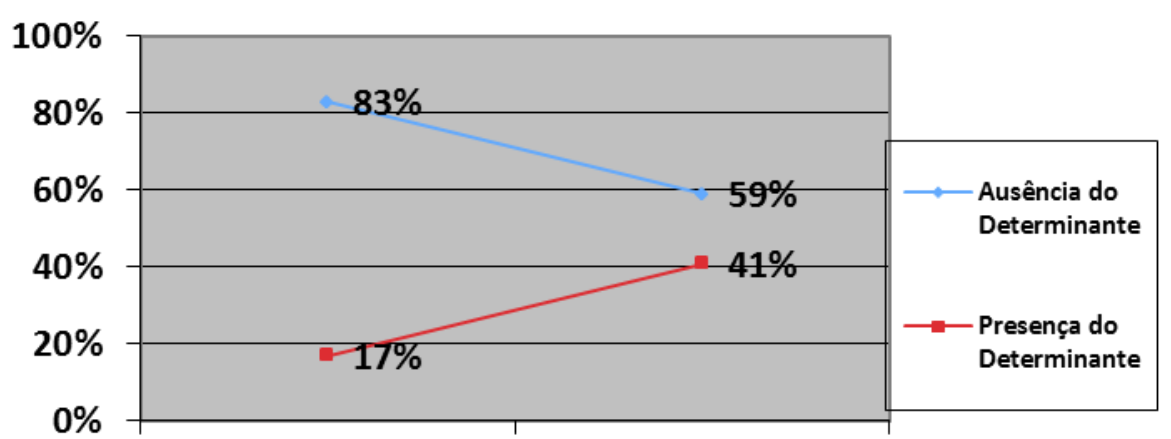

19.1

19.2

Gráfico 4.39: Frequência do determinante com posse Inalienável

\begin{tabular}{|c|c|c|}
\hline Posse alienável & $\begin{array}{c}\mathbf{1 9 . 1} \\
\text { Frequência }\end{array}$ & $\begin{array}{c}\mathbf{1 9 . 2} \\
\text { Frequência }\end{array}$ \\
\hline Ausência do determinante & $10 / 12(83 \%)$ & $10 / 17(59 \%)$ \\
\hline Presença do determinante & $2 / 12(17 \%)$ & $7 / 17(41 \%)$ \\
\hline Total & $12 / 29(41 \%)$ & $17 / 29(59 \%)$ \\
\hline
\end{tabular}

Tabela 4.27: Frequência do determinante com posse alienável

Os resultados apresentados nesta sessão mostram que, diacronicamente, a presença do determinante aumenta nos contextos de posse inalienável. Porém, sincronicamente, a posse inalienável favorece mais a não realização do artigo em relação à posse alienável (cf. tabelas e gráficos antecedentes), o que corroboram outros trabalhos sobre o tema.

Floripi (2008) e Nunes \& Floripi (2009) propõem uma categoria vazia em contextos de DPs de posse com nomes relacionais (parentesco). Os autores trabalharam com a estrutura desses DPs e mostraram como é possível licenciar uma categoria vazia, ou seja, após o movimento do possessivo. Por sua vez, Silva (1982) classifica o que nós chamamos de posse inalienável como posse com fator de especificidade marcante. O artigo é empregado com maior frequência nos contextos em que o possuído é [+ específico]. Os casos que acontecem sem determinante são aqueles em que o falante não necessita destacar nenhum elemento do 
conjunto, a informação já é clara. O fator especificidade explicaria, portanto, o uso reduzido do determinante com posse inalienável nos dados da autora. Vale salientar que Silva usa o fator especificidade como favorecedor do emprego do determinante e não obrigatório.

\subsubsection{Tipos de texto}

Quanto aos fatores externos, um deles diz respeito aos tipos de textos. Dentro do nosso corpus, três tipos de textos foram escolhidos: anúncios, carta de leitores e carta de redatores abrangendo primeira e segunda metade do século XIX.

Considerando um total de 365 ocorrências, contatamos que 159 (44\%) aparecem nos anúncios; 91 (24\%) provem das cartas de leitores e 115 (31\%) das cartas de redatores. No gráfico 4.40 e tabela 4.28 é possível visualizar melhor os percentuais acima:

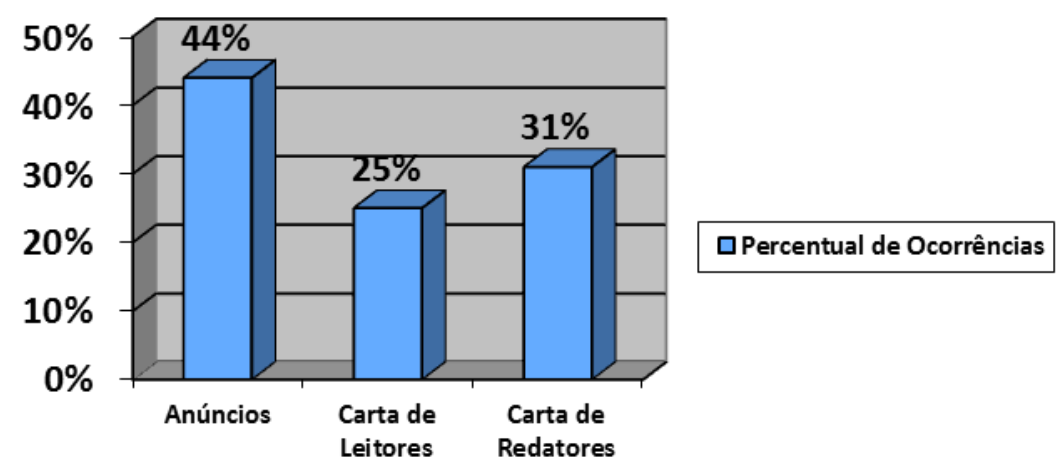

Gráfico 4.40: Ocorrências dos possessivos por tipos de textos

\begin{tabular}{|c|c|}
\hline Tipo de Texto & Número de ocorrências \\
\hline Anúncios & $159 / 365(44 \%)$ \\
\hline Carta de Leitores & $91 / 365(25 \%)$ \\
\hline Carta de Redatores & $115 / 365(31 \%)$ \\
\hline
\end{tabular}

Tabela 4.28: Número de ocorrências dos possessivos por tipo de texto

Diante desse percentual de ocorrências, qual é a frequência geral do uso do determinante nos contextos apresentados? No gráfico 4.41 e na tabela 4.29 , observamos que os anúncios são o que menos favorecem o uso do artigo (68\%), enquanto cartas de leitores e 
redatores estão bem próximas de um percentual não muito representativo (51\% e 54\%, respectivamente).

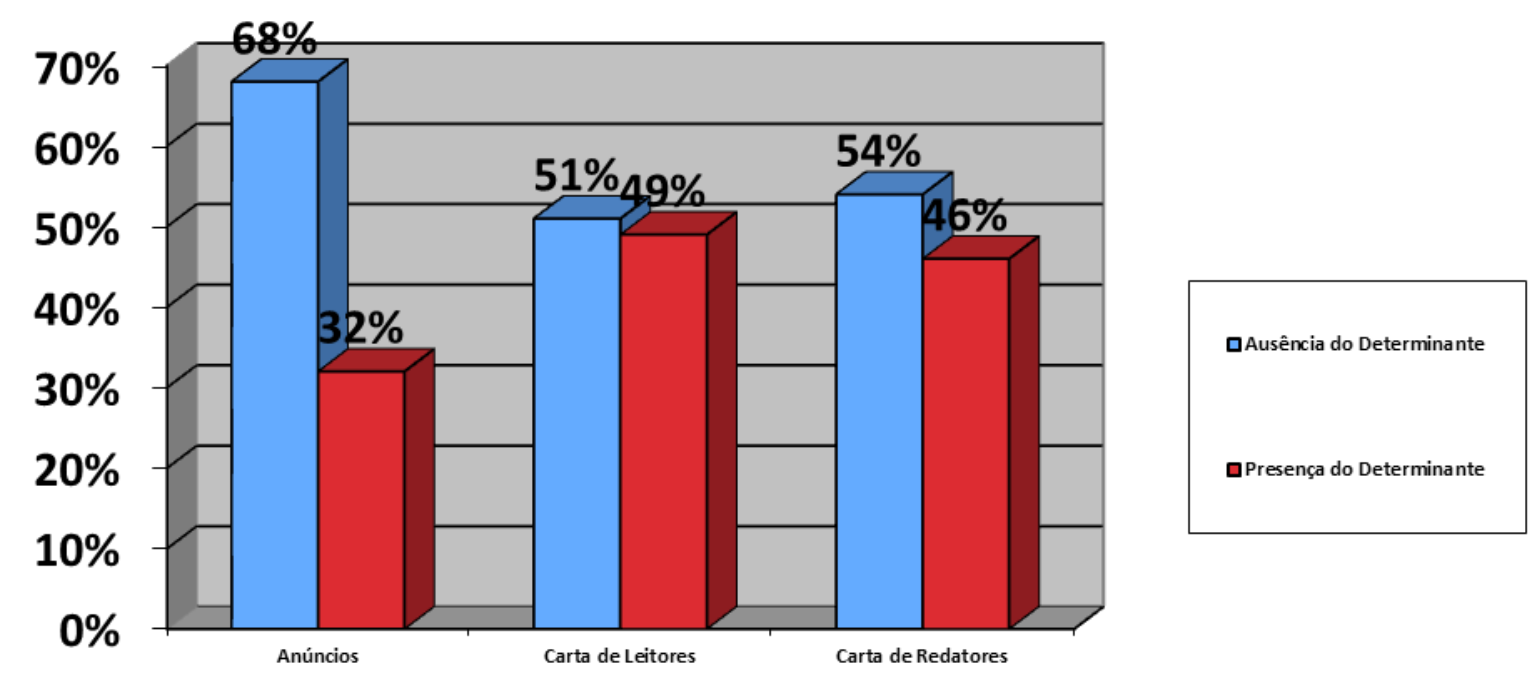

Gráfico 4.41: Frequência geral do determinante diante do possessivo por tipo de texto

\begin{tabular}{|c|c|c|}
\hline Tipo de Texto & $\begin{array}{c}\text { Frequência geral sem } \\
\text { Determinante }\end{array}$ & $\begin{array}{c}\text { Frequência geral com } \\
\text { Determinante }\end{array}$ \\
\hline Anúncios & $108 / 159(68 \%)$ & $51 / 159(32 \%)$ \\
\hline Carta de Leitores & $46 / 91(51 \%)$ & $45 / 91(49 \%)$ \\
\hline Carta de Redatores & $61 / 115(54 \%)$ & $54 / 115(46 \%)$ \\
\hline Total & $215 / 365(59 \%)$ & $150 / 365(41 \%)$ \\
\hline
\end{tabular}

Tabela 4.29: Frequência geral do determinante diante do possessivo por tipo de texto

Abaixo podemos fazer uma análise cronológica dos dados apresentados acima, considerando as duas metades do século XIX. Uma vez que a maior parte do corpus é formada por anúncios, cabe a nós analisarmos as ocorrências do determinante nesses e nos demais contextos (cf. gráficos 4.42 a 4.47 e tabelas 4.30 a 4.32). 


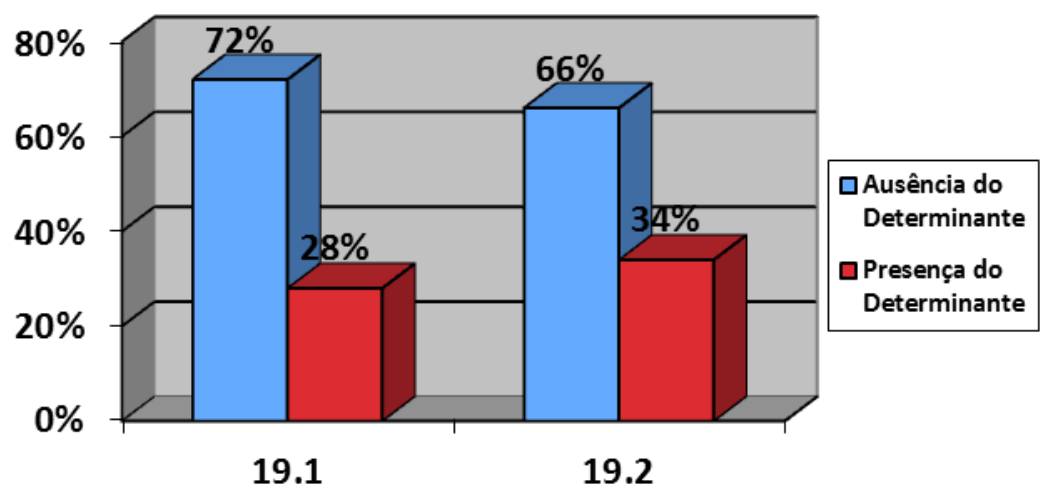

Gráfico 4.42: Frequência do determinante diante do possessivo em anúncios

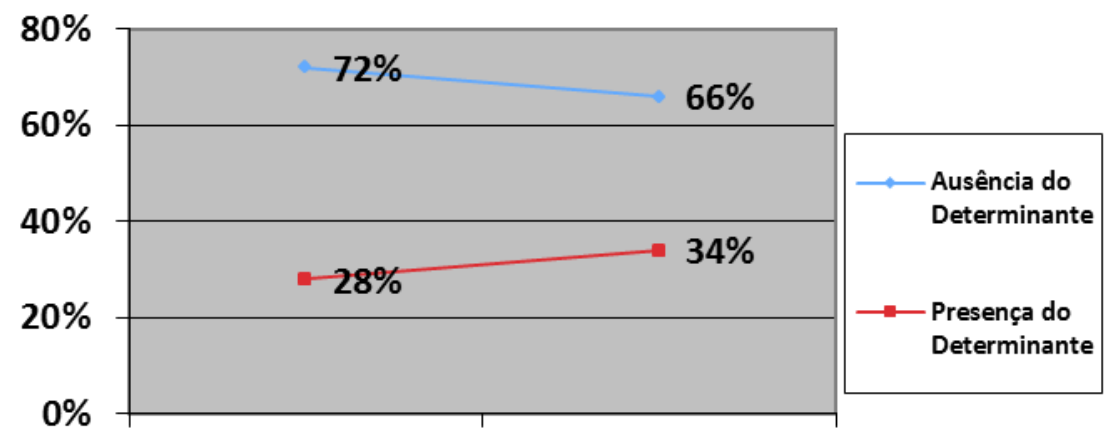

19.1

19.2

Gráfico 4.43: Frequência do determinante diante do possessivo em anúncios

\begin{tabular}{|c|c|c|}
\hline Anúncios & $\begin{array}{c}\mathbf{1 9 . 1} \\
\text { Frequência }\end{array}$ & $\begin{array}{c}\mathbf{1 9 . 2} \\
\text { Frequência }\end{array}$ \\
\hline Ausência do determinante & $33 / 46(72 \%)$ & $75 / 113(66 \%)$ \\
\hline Presença do determinante & $13 / 46(28 \%)$ & $38 / 113(34 \%)$ \\
\hline Total & $46 / 159(29 \%)$ & $113 / 159(71 \%)$ \\
\hline
\end{tabular}

Tabela 4.30: Frequência do determinante diante do possessivo em anúncios

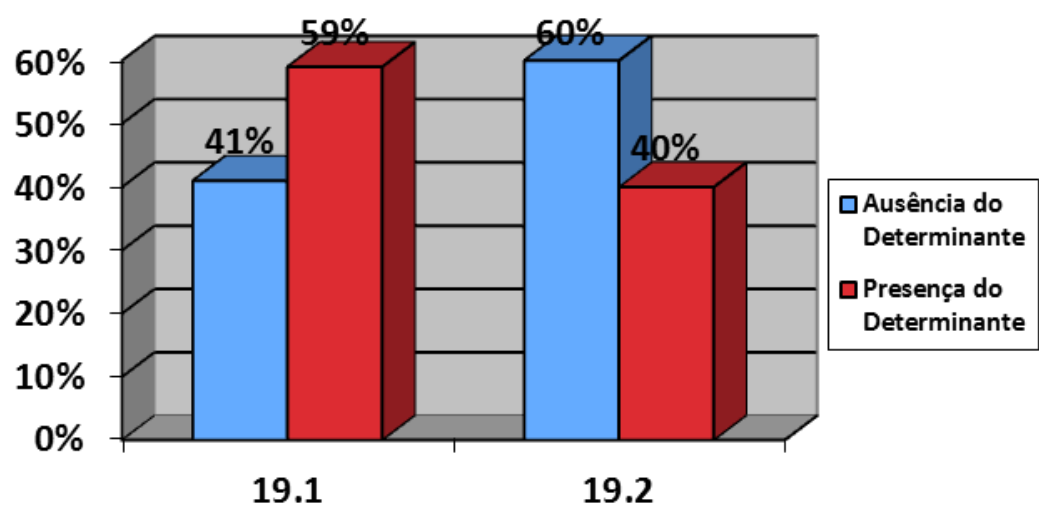

Gráfico 4.44: Frequência do determinante diante do possessivo em carta de leitores 


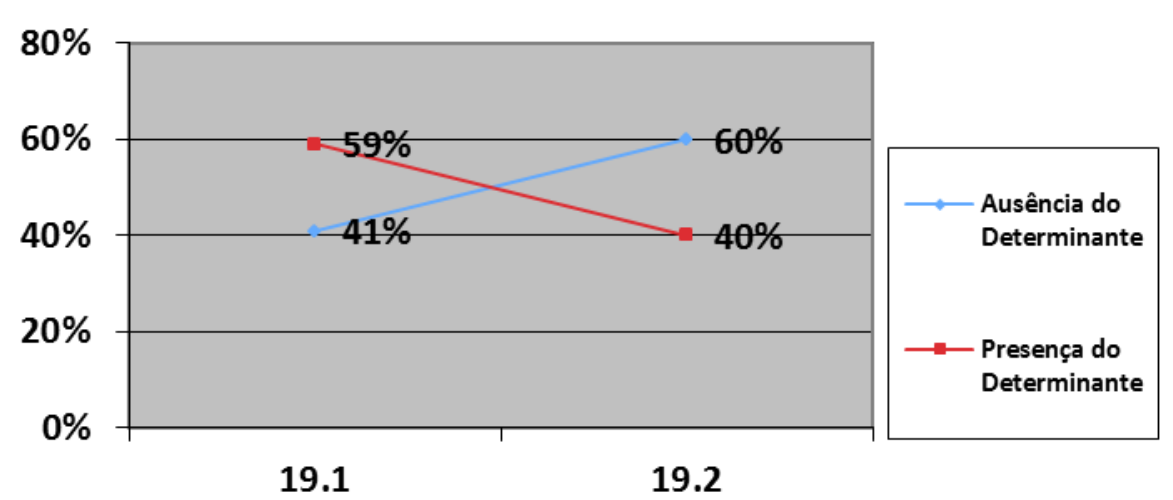

Gráfico 4.45: Frequência do determinante diante do possessivo em carta de leitores

\begin{tabular}{|c|c|c|}
\hline Carta de Leitores & $\begin{array}{c}\mathbf{1 9 . 1} \\
\text { Frequência }\end{array}$ & $\begin{array}{c}\mathbf{1 9 . 2} \\
\text { Frequência }\end{array}$ \\
\hline Ausência do determinante & $18 / 44(41 \%)$ & $28 / 47(60 \%)$ \\
\hline Presença do determinante & $26 / 44(59 \%)$ & $19 / 47(40 \%)$ \\
\hline Total & $44 / 91(48 \%)$ & $47 / 91(52 \%)$ \\
\hline
\end{tabular}

Tabela 4.31: Frequência do determinante diante do possessivo em carta de leitores

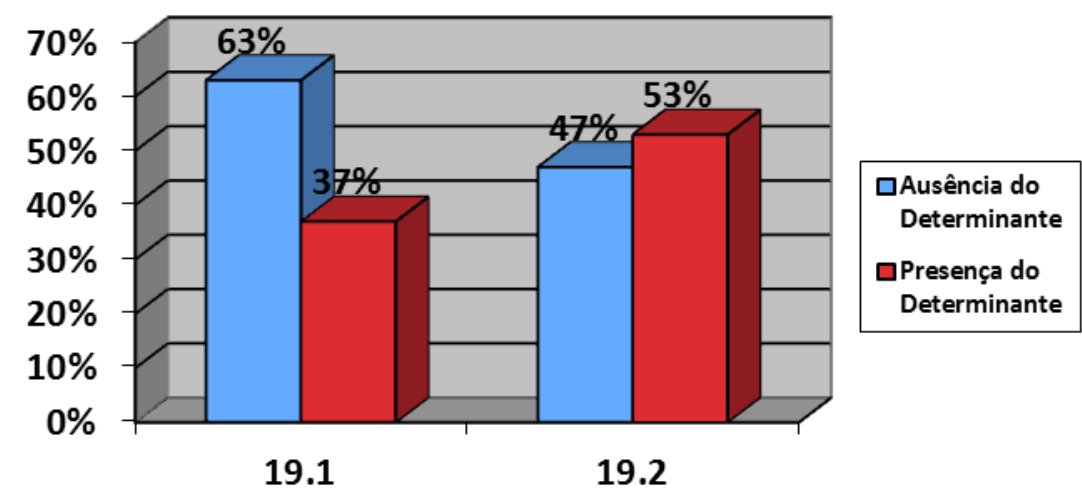

Gráfico 4.46: Frequência do determinante diante do possessivo em carta de redatores

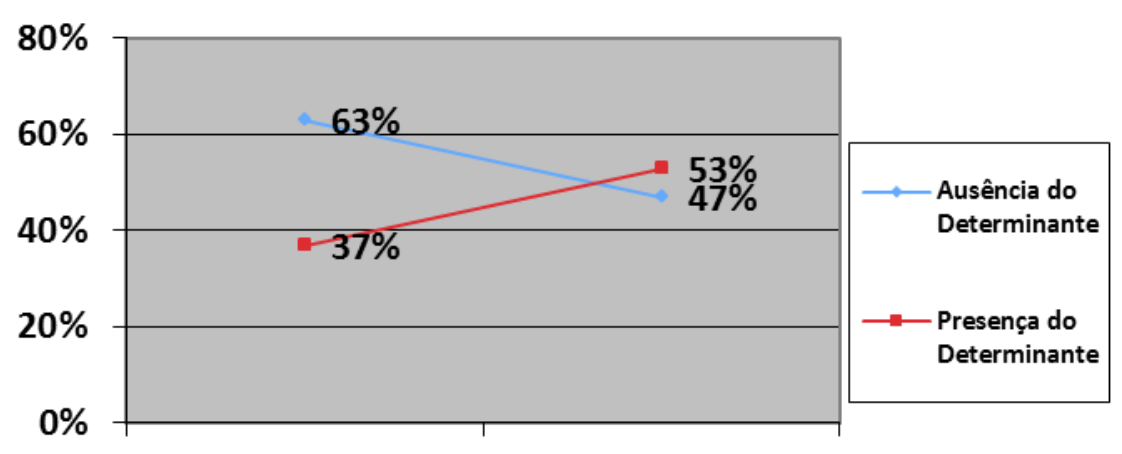

19.1

19.2

Gráfico 4.47: Frequência do determinante diante do possessivo em carta de redatores 


\begin{tabular}{|c|c|c|}
\hline Carta de Redatores & $\begin{array}{c}\mathbf{1 9 . 1} \\
\text { Frequência }\end{array}$ & $\begin{array}{c}\mathbf{1 9 . 2} \\
\text { Frequência }\end{array}$ \\
\hline Ausência do determinante & $26 / 41(63 \%)$ & $35 / 74(47 \%)$ \\
\hline Presença do determinante & $15 / 41(37 \%)$ & $39 / 74(53 \%)$ \\
\hline Total & $41 / 115(36 \%)$ & $74 / 115(64 \%)$ \\
\hline
\end{tabular}

Tabela 4.32: Frequência do determinante diante do possessivo em carta de redatores

É importante ressaltar que, dos três tipos de textos encontrados, dois são escritos pelos leitores: anúncios e cartas. Nesses dois contextos, de fato, a ausência do determinante é predominante, principalmente na segunda metade do século XIX $(66 \%$ e 60\%, respectivamente). As cartas de redatores, por sua vez, apresentam aspectos mais formais da língua, com $47 \%$ de ausência do determinante para a segunda metade do século.

Desta forma, podemos concluir que quanto maior o nível de formalidade, menor o uso do artigo. Vale a pena ressaltar, portanto, que nos anúncios há uma maior ausência do artigo (68\%) - maior formalidade - em cartas de leitores há 51\% de ausência para 54\% em cartas de redatores - menor formalidade.

\subsubsection{Localidade do texto}

O último dos contextos levado em consideração para análise verifica a localidade das sentenças, uma vez que trabalhamos com jornais tanto da capital como do interior. Das 365 sentenças, $260(72 \%)$ são dados da capital e 105 (28\%) são dados do interior. Abaixo é possível apresentar os resultados desse fator analisando o número de ocorrências, o uso do determinante em um panorama geral e o uso do determinante em um panorama específico, ou seja, dividido por local e período: 


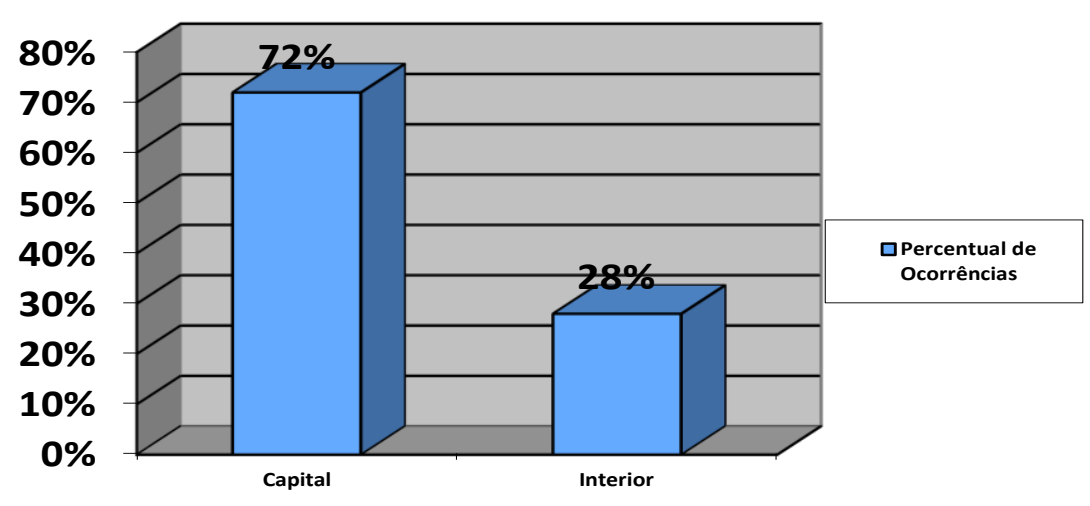

Gráfico 4.48: Ocorrência dos Possessivos por Localidade

\begin{tabular}{|c|c|}
\hline Localidade & Número de ocorrências \\
\hline Capital & $260 / 365(72 \%)$ \\
\hline Interior & $105 / 365(28 \%)$ \\
\hline
\end{tabular}

Tabela 4.33: Número de ocorrências dos possessivos por localidade

Tendo em vista o panorama geral do gráfico 4.48 e da tabela 4.33, o gráfico 4.49 e tabela 4.34 apresentam a frequência do determinante diante do possessivo por localidade. Os resultados mostram que na capital a ausência do determinante é 5\% maior que no interior, gerando um panorama inconclusivo para uma constatação de mudança em progresso.

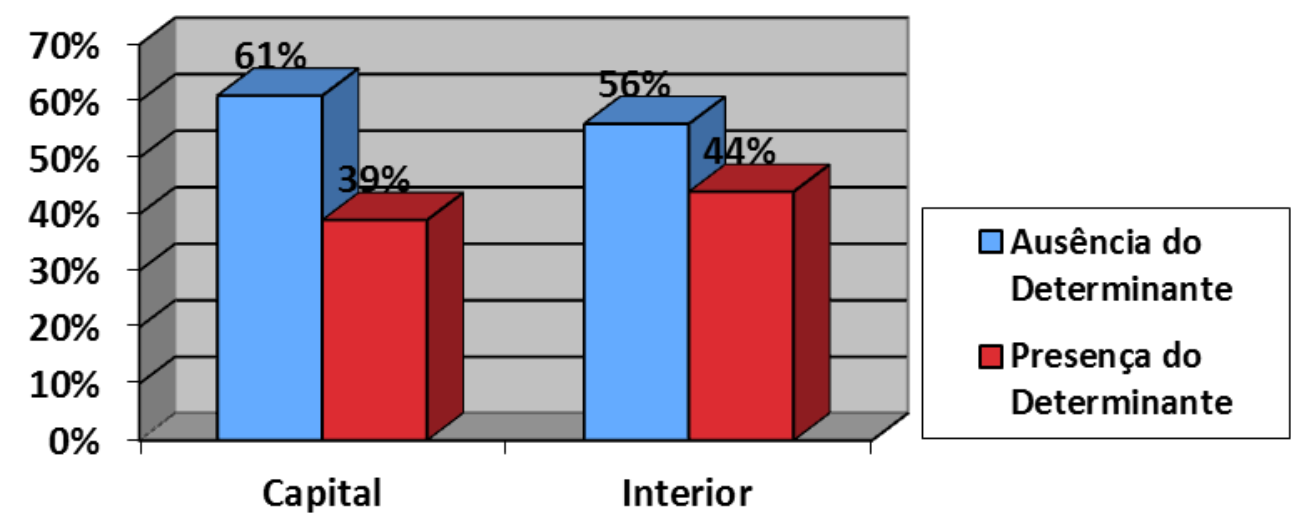

Gráfico 4.49: Frequência geral do determinante diante do possessivo por localidade 


\begin{tabular}{|c|c|c|}
\hline Localidade & $\begin{array}{c}\text { Frequência sem } \\
\text { Determinante }\end{array}$ & $\begin{array}{c}\text { Frequência com } \\
\text { Determinante }\end{array}$ \\
\hline Capital & $157 / 260(61 \%)$ & $103 / 260(39 \%)$ \\
\hline Interior & $58 / 105(56 \%)$ & $47 / 105(44 \%)$ \\
\hline
\end{tabular}

Tabela 4.34: Frequência geral do determinante diante do possessivo por localidade

Os gráficos 4.50, 4.51 e tabela 4.35 representam a frequência do determinante diante do possessivo na cidade de São Paulo (capital) segundo o período: 59\% (77/131) de ausência para a primeira metade do século XIX e 62\% (80/129) para a segunda.

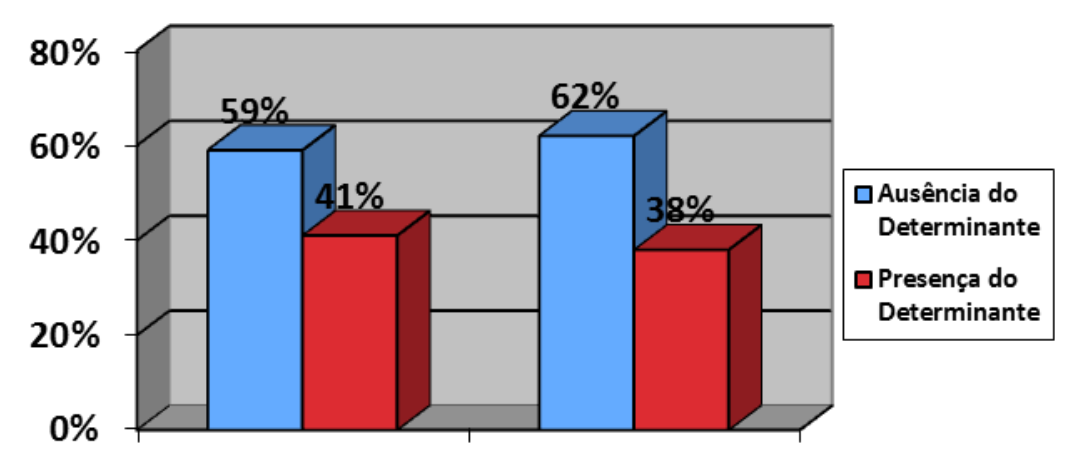

19.1

19.2

Gráfico 4.50: Frequência do determinante diante do possessivo na Capital

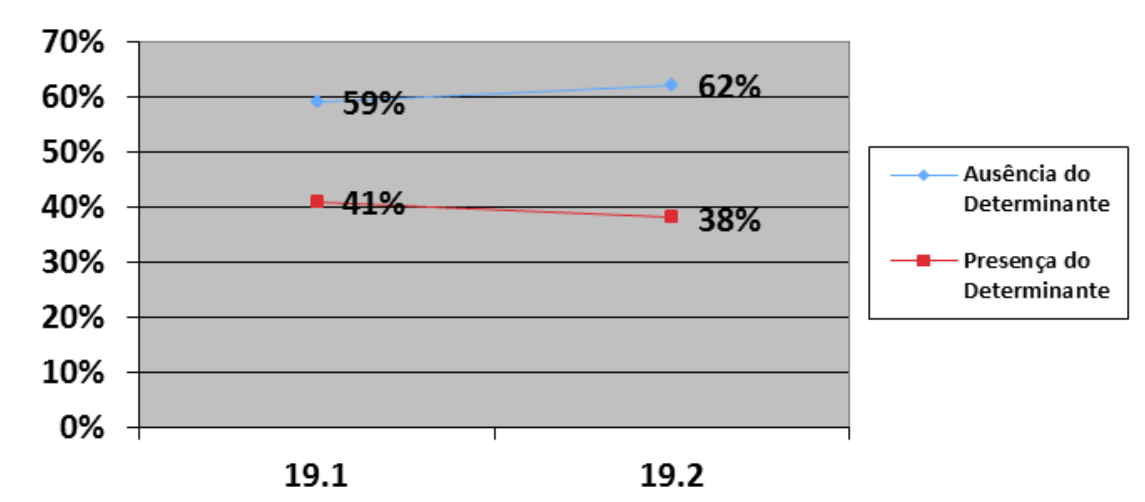

Gráfico 4.51: Frequência do determinante diante do possessivo na Capital

\begin{tabular}{|c|c|c|}
\hline Capital & $\begin{array}{c}\mathbf{1 9 . 1} \\
\text { Frequência }\end{array}$ & $\begin{array}{c}\mathbf{1 9 . 2} \\
\text { Frequência }\end{array}$ \\
\hline Ausência do determinante & $77 / 131(59 \%)$ & $80 / 129(62 \%)$ \\
\hline Presença do determinante & $54 / 131(41 \%)$ & $49 / 129(38 \%)$ \\
\hline Total & $131 / 260(50,3 \%)$ & $129 / 260(50,7 \%)$ \\
\hline
\end{tabular}

Tabela 4.35: Frequência do determinante diante do possessivo na Capital

No interior, considerando as cinco mil palavras selecionadas por categoria textual e período, não há ocorrências na primeira metade do século XIX, apenas na segunda: 55\% (58/105) é o percentual para a ausência do determinante e 45\% (47/105) para a presença. 


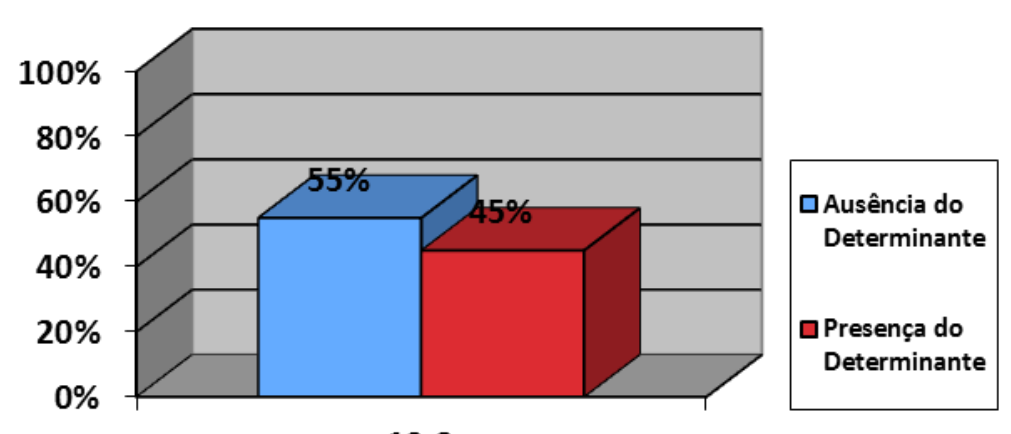

19.2

Gráfico 4.52: Frequência do determinante diante do possessivo no Interior

\begin{tabular}{|c|c|}
\hline Interior & $\begin{array}{c}\mathbf{1 9 . 2} \\
\text { Frequência }\end{array}$ \\
\hline Ausência do determinante & $58 / 105(55 \%)$ \\
\hline Presença do determinante & $47 / 105(45 \%)$ \\
\hline
\end{tabular}

Tabela 4.36: Frequência do determinante diante do possessivo no Interior

Observamos um aumento da frequência de ausência do determinante da primeira metade do século XIX para a segunda para os dados da capital: de 59\% para 62\%. Apesar de o aumento ser pequeno, ele é representativo, visto que esse número representa $72 \%$ das ocorrências encontradas em todo o corpus. Para o interior, apenas dados da metade do século XIX foram encontrados, impossibilitando uma análise diacrônica nesse fator, mas demonstrando que o uso do determinante está em variação (55\% de ausência e $45 \%$ de presença), seguindo os dados gerais da presente pesquisa.

\subsection{Considerações finais sobre os resultados apresentados}

Como já visto no capítulo 1, Kroch (1989) argumenta que uma mudança acontece quando novas formas surgem nos dados e se espalham ao longo dos anos, exibindo um comportamento estatístico específico. Esse comportamento é caracterizado por uma baixa frequência no início da instauração da mudança e uma substituição gradual das formas antigas pelas novas, desenhando uma curva em $\mathrm{S}$, em um gráfico em que o eixo $\mathrm{X}$ é o tempo e o eixo $\mathrm{Y}$ a frequência das formas.

Em particular, como apresentamos no capítulo 2, a presença de determinante diante de sintagmas possessivos é obrigatória no PE, mas não em PB. Por meio do gráfico 4.53, em que Floripi (2008) apresenta seus resultados sobre o PE, é possível exemplificar a curva S e notar 
um aumento no uso de determinantes em DPs possessivos no decorrer dos séculos XVI ao XIX. A curva evidencia uma variação no uso do determinante, mas que se direciona no sentido da sua obrigatoriedade em textos de escritores portugueses, caracterizando uma mudança de natureza microparamétrica.

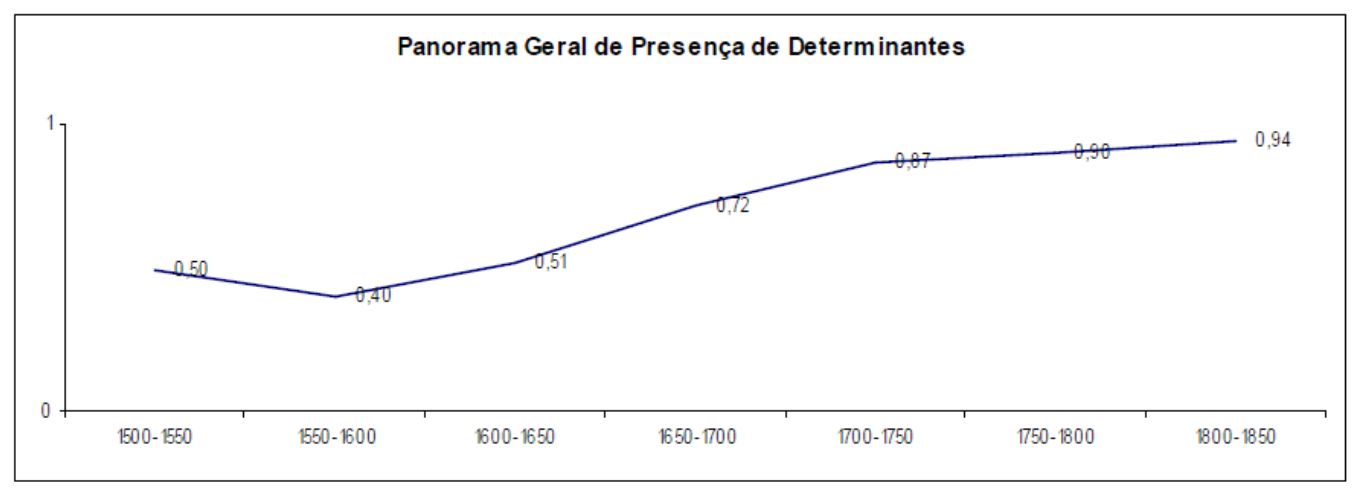

Gráfico 4.53 - Percentual de ocorrências do determinante nos DPs possessivos. ${ }^{96}$

Percebe-se que do século XVI até meados do século XVII há uma oscilação no uso do artigo em DPs possessivos: a realização dos artigos permeava os 50\%. A evolução no tempo revelada pelo gráfico demonstra que, a partir da segunda metade do século XVII, o uso do artigo diante do pronome possessivo passa a ter um crescimento acentuado, de 50\% a $70 \%$.

Segundo Floripi, essa implicação aponta o início da mudança e, seguindo uma direção além dos estudos já feitos sobre o tema, mostra que, sob uma perspectiva diacrônica, o fator crucial em questão era a presença da preposição junto ao DP possessivo, que ajudava na ausência do determinante antes dele se tornar, de fato, obrigatório.

Nos nossos dados, embora tenhamos trabalhado apenas com o século XIX, os resultados são inconclusivos para se propor algum indício de mudança em progresso numa situação de competição de gramáticas, que pudesse estar afetando quer a natureza do artigo definido, quer a natureza categorial dos possessivos. A média geral de ausência do determinante diante de sintagmas possessivos se manteve a mesma nos dois períodos analisados (primeira e segunda metades do século XIX): 58\% - gráfico 5.54. Não houve, portanto, como dissemos, indícios de oscilação no uso de uma ou outra variante que pudesse demonstrar o avanço de uma delas em detrimento de outra.

\footnotetext{
${ }^{96}$ Floripi (2008: 138). Gráfico 2 no original.
} 


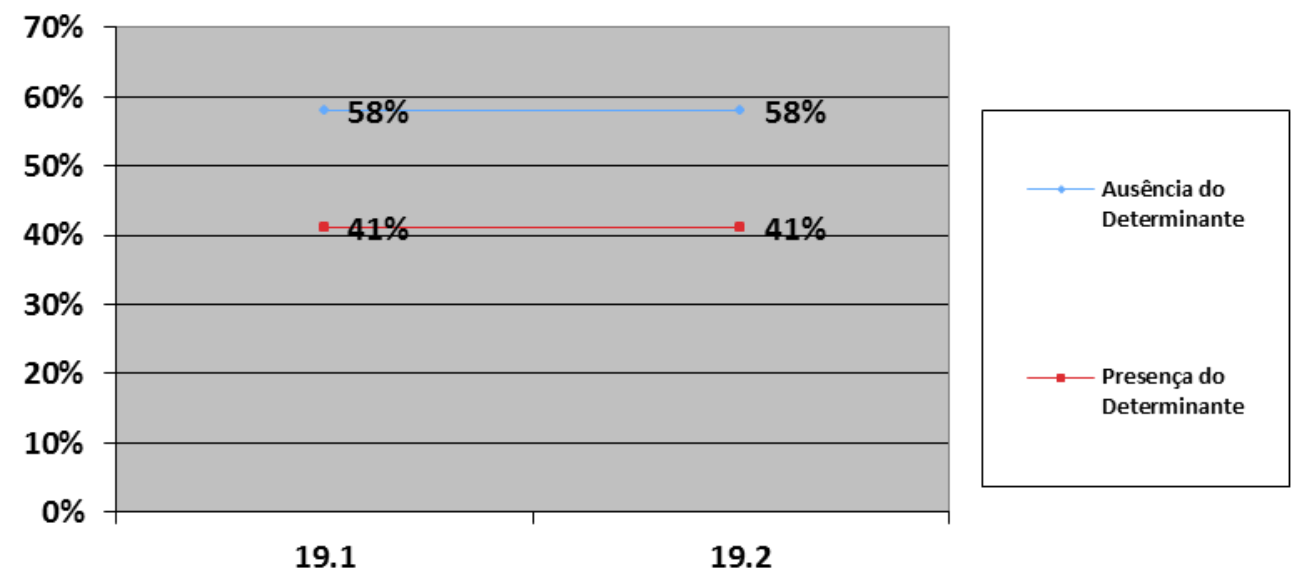

Gráfico 4.54: Ausência x Presença do Determinante por Período

Dessa forma, os resultados obtidos mostraram que a média geral de ausência do determinante diante de DPs possessivos se manteve a mesma nos dois períodos analisados, configurando uma variação estável. Como mencionado em outros momentos da dissertação, outros estudos realizados em diferentes tipos de corpora em diferentes regiões do Brasil mostraram o mesmo estatuto da variação, o que nos permite concluir que nesse aspecto da gramática não houve uma diferença dialetal relevante que diferenciasse um dialeto de outro. A analise teórica que foi assumida para a estrutura do DP possessivo no PB permite entender a razão dessa variação estável, uma vez que revela não se tratar de uma opcionalidade na realização ou apagamento do artigo. Por conseguinte, tanto o artigo realizado foneticamente como o artigo nulo tem as mesmas propriedades gramaticais nos diferentes dialetos do PB.

Pereira (2007) apresenta resultados semelhantes ao de nossa pesquisa. A autora mostra que a média geral dos pronomes reflexivos, objeto de seu estudo, entre um intervalo de dez anos, se manteve praticamente a mesma nos dois conjuntos de inquéritos analisados: $40 \%$ e $42 \%$, respectivamente ${ }^{97}$.

Assim como o trabalho de Pereira, o nosso estudo não apresenta mudança significativa em tempo real. Então o que está ocorrendo na língua se o uso não é categórico de uma das

\footnotetext{
${ }^{97}$ Pereira (2007), ao analisar 72 inquéritos do português popular em São Paulo, organizado por Rodrigues, propõe uma tese de mudança linguística. Os inquéritos formam dois conjuntos: um gravado entre os anos de 1986 e 1987, e outro, entre os anos de 1997 e 2001. A autora recolhe dos corpora ocorrências que expressam a ideia de reflexividade, reciprocidade, ou passividade, e nas quais se espera a realização de um pronome anafórico. Pereira comprovou que a realização dos pronomes reflexivos se manteve quase a mesma nos dois conjuntos de inquéritos ( $40 \%$ e $42 \%$ ), porém a variação não é aleatória: o uso do pronome explícito é decisivamente condicionado pelas suas funções semânticas (reflexivo verdadeiro, reflexivo recíproco, média de emoção), sintáticas (argumento, afixo) e discursivas (informação nova, foco). Para mais, a pesquisa da autora comprova que o falante pode empregar - ainda que com menor frequência - outras estratégias para expressar a noção de reflexividade, tais como o uso de um pronome tônico ou de um nome lexical.
} 
duas variantes? Como vimos no capítulo 1, tudo é possível quando tratamos de variação e mudança linguísticas. Os dados apontam para várias possibilidades: (i) mudança num ritmo lento, (ii) mudança na direção da mudança e (iii) variável estável. 


\section{CONCLUSÕES}

Nesta dissertação tivemos como principal objetivo a discussão de uma proposta de análise para a variação presença vs. ausência do determinante (artigo definido) diante dos possessivos pré-nominais de $3^{\text {a }}$ pessoa, seus, sua, seus, suas, a qual caracteriza a gramática do português brasileiro. A perspectiva que adotamos foi de natureza comparativa e histórica, com base num quadro teórico particular que contempla os pressupostos da teoria gerativa e da sociolinguística laboviana. Dentro da perspectiva comparativa, destacamos os aspectos gramaticais que hoje diferenciam as duas variedades do português: o português europeu (PE) e o português brasileiro (PB). Para as reflexões sobre a abordagem diacrônica do fenômeno gramatical em estudo, baseamo-nos não somente em resultados quantitativos apresentados em vários autores, como também contribuímos com um conjunto de dados que coletamos em anúncios e cartas de leitores e redatores de jornais paulistas ao longo do século XIX. Esse corpus jornalístico faz parte do acervo documental construído no âmbito do projeto temático de equipe Para a História do Português Paulista (PHPP), o qual, por sua vez, é um desdobramento de um projeto mais abrangente denominado Para a História do Português Brasileiro (PHPB).

Para atingir o nosso objetivo central, dividimos a dissertação em 4 capítulos.

No capítulo 1, apresentamos os dois quadros teóricos em que se baseiam a nossa análise: a teoria dos Princípios \& Parâmetros (CHOMSKY 1981, 1986) incluindo alguns refinamentos do Programa Minimalista (CHOMSKY 1995, 1998, 2000, 2001, 2004), e os pressupostos elaborados dentro da Sociolinguística Laboviana (cf. WEINREICH, LABOV E HERZOG (WLH) (1968); LABOV (1972)), considerando ainda estudos posteriores que conciliaram a mudança paramétrica "internalista" da língua (ROBERTS (2007)) com fatores extragramaticais que determinam o percurso das formas linguísticas no tempo histórico (KROCH (1989, 1994, 2000)).

No mesmo capítulo, destacamos o estudo de Pereira (2007), não apenas por sua aplicação da metodologia variacionista, como também pelos resultados que alcançou na investigação dos pronomes reflexivos, os quais foram muito semelhantes aos que encontramos na nossa pesquisa.

No capítulo 2 buscamos particularizar as nossas leituras para alguns trabalhos relevantes aos nossos objetivos. Dialogamos e destacamos os pontos principais das propostas de Floripi (2008), Magalhães (2002), Rinke (2010), Costa (2002), Castro (2006) e Brito (2007). 
Como dito anteriormente, em todos os artigos resenhados constatamos que houve uma preocupação em discutir o percurso diacrônico do artigo definido nos contextos de possessivos pré-nominais na história do português. Tal percurso foi também bastante relevante porque retratou os rumos distintos tomados pelo PE e PB ao longo do tempo. Enquanto o artigo definido acompanha os sintagmas nominais com pronome possessivo no PE, o mesmo é sistematicamente omitido no português antigo do século XIII. No PB, porém, a variação presença vs. ausência de artigo diante dos possessivos se mantém estável.

Esse capítulo considerou que os estudos nele apresentados ofereceram um conjunto de reflexões teóricas e empíricas que muito contribuíram para as nossas reflexões sobre o PB.

No terceiro capítulo encontramos respostas, com base no estudo de Torres Morais (inédito), calcado nas hipóteses desenvolvidas em Borik, Cyrino \& Espinal (2012) e por Cyrino \& Espinal (2013/2014), para as seguintes indagações: (i) na estrutura interna do DP possessivo, a presença do possessivo altera as relações de valoração morfossintática de número no determinante? (ii) Onde seria gerada a forma possessiva? (iii) A estrutura interna se altera com a projeção de um núcleo funcional que valora traços dos possessivos? (iv) Como expressar estruturalmente a relação de posse entre o possuidor e o possuído?

Como vimos, as autoras desenvolvem uma abordagem sintática, assumindo aspectos do programa minimalista, para descrever e explicar a distribuição de Nomes Nus (BNs) em PB. São assumidas duas hipóteses de trabalho, formuladas nos seguintes termos: H1: Na posição de argumentos, BNs são DPs com um determinante nulo e projeção de Número (Num P); H2: Número é morfossintaticamente valorado e interpretado em $\mathrm{D}$, mesmo quando o determinante é nulo. Ambas as hipóteses confirmam assim que o PB não se afasta das outras línguas românicas na hipótese do DP Universal, proposta por Longobardi (1994) e outros.

Portanto em BP, os BNs podem ser expressões definidas (individualizadas, referenciais).

Vimos como Torres Morais (inédito) assume a hipótese dos BNs como DPs definidos, para a sua proposta de que, no PB, os DPs possessivos, com ou sem artigo realizado lexicalmente são expressões definidas, com a mesma natureza dos "BNs" argumentais. Nesses termos, não se tem uma opcionalidade no uso dos artigos antes de possessivos no PB, mas um situação de "variação inerente" ao sistema, ou seja, em ambos os casos, o artigo é o marcador de definitude e o criador de argumento.

No entanto, a presença dos possessivos no interior do DP, no PB, obriga a que sejam feitas algumas reformulações na $\mathrm{H} 1$ e $\mathrm{H} 2$, as quais ficam caracterizadas nos seguintes termos: (i) D é o local da definitude; (ii) O determinante, nulo ou realizado, é obrigatório para 
expressar a definitude; (iii) $\mathrm{Na}$ estrutura interna do DP possessivo, o traço [iNUM] é morfossintaticamente interpretado em $\mathrm{F}$ (iv) A categoria que porta a marca de plural é a primeira categoria funcional que merge após NumP.

Por fim, no capítulo 4, trouxemos resultados quantitativos de nossa abordagem referentes à variação na colocação dos artigos definidos em sintagmas nominais com formas possessivas de $3^{\mathrm{a}}$ pessoa, seu, sua, seus suas, em posição pré-nominal. Os resultados mostraram que a variável apresentada em nossos dados é estável, uma vez que não evidencia uma diferença semântica significativa quando o determinante aparece ou não no interior do DP possessivo. A média geral de ausência do determinante diante de sintagmas possessivos se manteve a mesma nos dois períodos analisados (primeira e segunda metades do século XIX): $58 \%$ - gráfico C.1. Não houve, portanto, uma mudança significativa ou dados que apontavam para uma mudança em direção à perda dos determinantes.

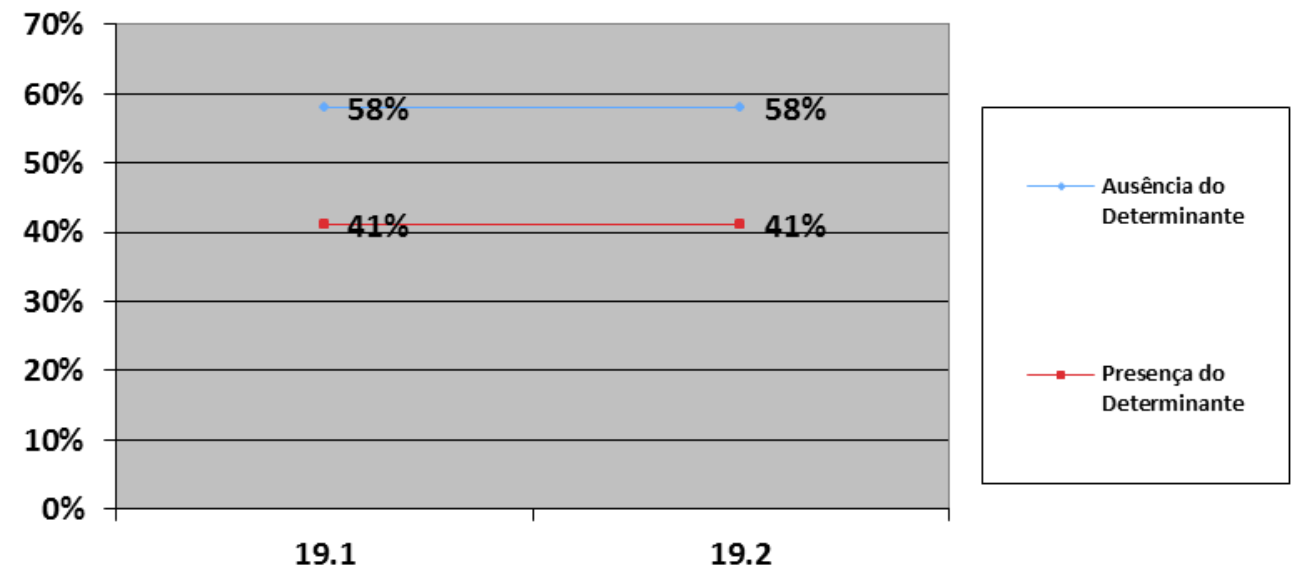

Gráfico C.1: Ausência x Presença do Determinante por Período

Podemos concluir dizendo que nossos resultados corroboraram a hipótese teórica assumida nesta dissertação, com respeito ao fenômeno da variação na realização do artigo definido nos contextos possessivos no PB.

Acreditamos reconhecer ainda em nossa dissertação dois aspectos importantes de contribuição. O primeiro diz respeito ao período histórico escolhido, as duas metades do século XIX. Por que tal período seria relevante? Em primeiro lugar, porque diferentes estudos históricos sobre o PB revelam que é no século XIX que as formas inovadoras já aparecem em competição com as forma conservadoras. Como vimos em Floripi (2008) em seu estudo dos textos produzidos por portugueses, o século XIX permite desenhar uma Curva-S, 
evidenciando a implementação da mudança a partir da qual a presença do determinante tornase obrigatória diante dos possessivos pré-nominais em diferentes tipos de contextos verbais.

Mais importante foi constatar que o avanço do artigo na variedade lusitana atinge os DPs possessivos, as expressões nominais genéricas e com nomes próprios de pessoa, que são os contextos que permitem variação no PB. Isso ficou bem descrito em Castro (2006).

O segundo aspecto da nossa contribuição tem uma perspectiva comparativa, uma vez que assumimos hipóteses para descrever as propriedades sintáticas e semânticas do DP possessivo, tanto para o PE quanto para o PB. Nossa hipótese para o PE foi a de que a obrigatoriedade do artigo nos DPs possessivos e nos contextos genéricos leva a um uso expletivo do mesmo - como em Castro (2006), porém ocasionando uma recategorização do possessivo que se torna uma forma fraca gerado em $\mathrm{D}$, realizando, nesta posição os traços de definitude e posse.

Para o PB, porém, a hipótese assumida é a de que a língua permite BNs, interpretados como DPs definidos em todas as posições argumentais, em diferentes tipos de expressões nominais, incluindo os DPs possessivos. Tais BNs são verdadeiros DPs, uma vez que D, realizado ou nulo é o portador das marcas de definitude e Número. Nos DPs possessivos, o traço [iNUM] de D é transferido para o núcleo F, responsável pela introdução do Possessivo no Spec, FP. 


\section{REFERÊNCIAS $^{98}$}

ABNEY, S. The English Noun Phrase in its Sentential Aspect. PhD Dissertation. MIT, 1987.

Alexiadou, A., HaEgeman, L. \& StaVRou, M. Noun Phrase in the Generative Perspective. Berlin: Mouton de Gruyter, 2007.

BARBOSA, Pilar; DUARTE, Maria Eugênia Lamoglia \& KATO, Mary Aizawa. "A distribuição do sujeito nulo no português europeu e no português brasileiro." In: Actas do XVI Encontro Nacional da Associação Portuguesa de Linguiística. Lisboa, 2001.

BARBOSA, Afrânio Gonçalves. Tratamento dos corpora de sincronias passadas da língua portuguesa no Brasil: recortes grafológicos e linguísticos. In: LOBO, Tânia et al. (Org.). Para a história do português brasileiro. v. 6, t. 2. Salvador: EDUFBA, 2006.

BERLINCK, Rosane de A. (1996) The Portuguese Dative. In: VAN BELLE, William \& VAN LANGENDONCK, William (eds.) The Dative. Vol. 2: Descriptive Studies. Amsterdam: John Benjamins Publishing Co. (Case and grammatical relations across languages; v.2), 1996.

BORGES NETO, J. Os Papéis do Possessivo no Sintagma Nominal. Estudos Lingüísticos Seminário do Gel, Mogi das Cruzes. (2), 62-69. (1978)

BORER, H. Anaphoric Agr. In: O. Jeggli \& K. Safir (orgs): 1989.

BORIK, O, CYRINO, S. \& ESPINAL, M.T. On Determiners in Languages with and without Articles. Workshop on Languages With and Without Articles. Paris March $15^{\text {th }}-16^{\text {th }} 2013$.

BIBERAUER, Theresa, and Ian Roberts. Negative words and related expressions: a new perspective on some familiar puzzles. In The Evolution of Negation: Beyond the Jespersen Cycle. Pierre Larrivée and Richard Ingham (eds). Berlin: Mouton de Gruyter, 2011.

BIBERAUER, Theresa, and Hedde Zeijlstra. Negative concord in Afrikaans: filling a typological gap. Journal of Semantics. 2012.

BRITO, A. Presença / ausência de artigo antes de possessivo no Português do Brasil. In: Actas do XVI Encontro da Associação Portuguesa de Linguística. Faculdade de Letras do Porto. Centro e Linguística da Universidade do Porto, 2001.

BRITO, A. Os possessivos em Português numa perspectiva de Sintaxe Comparada. Revista da Faculdade de Letras - Línguas e Literaturas XX, 2003.

BRITO, A. European Portuguese possessives and the structures of DP. Cuadernos de Linguiística del I.U.I. Ortega y Gasset. vol 14. 2007

CANÇADO, M. \& NEGRÃO, E.. Two possessor-raising constructions in Brazilian Portuguese. VIII Workshop on Formal Linguistics. São Paulo: USP, 2010.

\footnotetext{
${ }^{98}$ De acordo com a Associação Brasileira de Normas Técnicas. NBR 6023.
} 
CARDINALETTI, Anna. On the de_cient/strong opposition in possessive systems. In: Possessors, predicates and movement in the determiner phrase , ed. Artemis Alexiadou and Chris Wilder, 17_53. Amsterdam/Philadelphia: John Benjamins, 1998.

CARDINALETTI, Anna, e STARKE, Michal. The Tipology of Structural De_ciency: a Case Study of Three Classes of Pronouns. In: Clitics in the languages of europe, ed. Henk van Riemsdijk, 33_82. Berlin/New York: Mouton de Gruyter,1999.

CASTRO, A. Os Possessivos em Português Europeu e Português Brasileiro: Unidade e Diversidade. Actas do XVI Encontro Nacional da Associação Portuguesa de Linguística de Coimbra. Lisboa. APL. 599-613, 2000.

CASTRO, A. On possessives in portuguese. Tese de doutorado. Lisboa / Paris: Universidade Nova de Lisboa / Université Paris 8 - Vincennes Saint- Denis, 2006.

CASTRO, A. \& COSTA, J. Weak forms as $\mathrm{X}^{\mathrm{o}}$ : prenominal possessives and preverbal adverbs in European Portuguese. In: Romance Linguistics: Theory and acquisition. Pérez-Leroux, A. T. \& Roberge, Yves (eds). 95-110. Amsterdam/Philadelphia: John Benjamins, 2002.

CERQUEIRA, V. C. A forma genitiva "dele" e a categoria de concordância (AGR) no português brasileiro. In: Roberts, I. \& Kato, M. (eds.) Português Brasileiro: uma viagem diacrônica. Campinas, UNICAMP, 1993.

CERQUEIRA, V. C. A Sintaxe do Possessivo no Português Brasileiro. Tese de doutorado. Campinas: UNICAMP, 1996.

CHIERCHIA, G. Reference to kinds across languages. Natural Language Semantics. 6:339405, 1998.

CHOMSKY, N. Syntactic Structures. The Hague: Mouton, 1957.

CHOMSKY, N. Rules and Representations. New York: Columbia University Press, 1981.

CHOMSKY, N. Barriers. Cambridge, MA: MIT Press, 1986.

CHOMSKY, N. The Minimalist Program. Cambridge. Mass: MIT Press, 1995.

CHOMSKY, N. Derivation by Phase. Cambridge. MA: MIT Press, 1999.

CHOMSKY, N. Minimalist Inquiries: the Framework. In: Martin, R. D. Michaels, D. \& Uriagereka, J. (eds.) Step by Step: Essays on Minimalist Syntax. In Honor of Howard Lasnik. Cambridge, Mass: MIT Press, 2000.

CHOMSKY, N. Derivation by Phase. In: Kenstowicz, M. (ed.). Ken Hale: A Life in Language. Cambridge, Mass.: MIT Press, 2001.

COELHO, Izete Lehmkuhl... [et al.]. Para conhecer sociolinguística - São Paulo: Contexto, 2015. - (Coleção para conhecer linguística).

COSTA, I. 'O uso do artigo definido diante de nome proprio de pessoa e de possessivo do seculo XIII ao seculo XVI'. IN: Mattos e Silva \& Machado Filho, A. V. L. (ed.) O Português Quinhentista - Estudos Lingüísticos. EDUFBA/UEFS, 2002. 
COSTA, J. \& FIGUEIREDO SILVA, M. C. Nominal and Verbal Agreement in Portuguese: An Argument for Distributed Morphology. In: Costa, J. \& Figueiredo Silva, M. C. (eds). Studies on Agreement. Linguistik Aktuell. John Benjamins Publishing Co., 2006.

CYRINO, S. \& ESPINAL. M.T Bare nominals in Romance: exploring microvariation in the nominal domain. University of Modena and Reggio Emilia. Feb 21-23 ${ }^{\text {rd }}, 2013$.

CYRINO, S. M. L.; DUARTE, M. E. \& KATO, M. A.. "Visible subjects and invisible clitics in Brazilian Portuguese". In: KATO, Mary Aizawa \& NEGRÃO, Esmeralda. V. (orgs.). Brazilian Portuguese and the Null Subject Parameter. Frankfurt: VervuertIberoAmericana, 2000.

CYRINO, Sonia; ESPINAL, Maria Teresa Bare Nominals in Brazilian Portuguese: more on the DP/NP analysis. In: Natural Language and Linguistic Theory. (no prelo)

DELSING, L. O. The Scandinavian Noun Phrase. Working Papers in Scandinavian Syntax 42:57-79. 1988.

DENISON, D. Log(ist)ic and Simplistic S-curves, In: HICKEY, R. (ed.). Motives for language change. Cambridge: Cambridge University Press, 2003.

DÉPREZ, Viviane. Morphological number, semantic number and bare nouns. Lingua. 115: 857-883, 2005.

DUARTE, M.E.L. Do pronome nulo ao pronome pleno. In: I.Roberts \& M.A Kato (eds),107-128, 1993.

DUARTE, M. E. \& KATO, M. A.. Restrições na distribuição de sujeitos nulos no Português Brasileiro. In: Veredas: sintaxe das línguas. V. 18/1. Juiz de Fora, UFJS: 2014.

FLORIPI, S. A. Argumentos Nulos dentro de DPs em Português Brasileiro. Dissertação de Mestrado. Unicamp. Campinas, 2003.

FLORIPI, S. A. Estudo da variação do determinante em sintagmas nominais possessivos na história do Português. Tese de Doutorado. Unicamp. Campinas, 2008.

FLORIPI S. \& NUNES, J. Movement and resumption in null possessor constructions in Brazilian Portuguese. In: Nunes, J. (ed.) Minimalist Essays on Brazilian Portuguese Syntax. Amsterdam / Philadelphia. John Benjamins Publishing Company. Vol. 142. 51-6, 2009.

FUKUI, N e M. SPEAS, Specifiers and Projection. MIT working Papers 8:128-172. 1986.

GAlVES, C; BRITTO, H. \& M.C. PAIXÃO DE SOUSA, Clitic Placement in European Portuguese, 2003. www.ime.usp.br/ tycho/participants/c_galves/GBPS_2003.htm, 20/07/2004.

GALVES, Ch A sintaxe do português brasileiro. Ensaios Lingüísticos,13:31-50, 1987.

GALVES, Ch O enfraquecimento da concordância no Portugues Brasileiro. In Roberts \& Kato (eds), Português Brasileiro: uma viagem diacrônica, Unicamp, Campinas, 1993.

GALVES, Charlotte Ensaios sobre as Gramáticas do Português. Campinas: Editora da 
UNICAMP, 2001.

GALVES, C. L'objet nul et la structure de la proposition en portugais du Brésil', Revue des Langues Romanes, 93, pp. 305-336, 1989.

GALVES, C. 'O enfraquecimento da concordância no Português Brasileiro'. In: ROBERTS, I \& KATO, M. (eds) Português Brasileiro: uma viagem diacrônica, Unicamp, Campinas. (p.387-408), 1996.

GALVES, C. Padrões Rítmicos, Fixação de Parâmetros e Mudança Lingüística, Fase II. Campinas, UNICAMP. (Projeto de Pesquisa), 2004.

GAlveS, C; Britto, H. \& M.C. Paixão de Sousa, Clitic Placement in European Portuguese, $2003 \quad$ http://www.ime.usp.br/ tycho/participants/c_galves/GBPS_2003.htm, 20/07/2004

GALVES C, H. Britto \& M.C. Paixão de Sousa "The Change in Clitic Placement from Classical to Modern European Portuguese: Results from the Tycho Brahe Corpus", Journal of Portuguese Linguistics, vol. 4.1, Special Issue on Variation and Change in the Iberian Languages: the Peninsula and beyond José Ignacio Hualde (org.), pp.39-67. 2005.

GALVES, C. A sintaxe da Grammatica, publicado nas Atas do Colóquio "Fernão de Oliveira: 500 anos", 2008. IEL-UNICAMP, 24-26/09/2007.

GHOMESHI, JILA, ILEANA PAUL, and MARTINA WILTSCHKO (eds.). Determiners. Universals and variation. Amsterdam: John Benjamins, 2009.

GIORGI, A. e LONGOBARDI, G. The syntax of Noun Phrases. Cambridge: Cambridge University Press, 1990.

GUEDES, M. \& BERLINCK, R.A. (orgs.) E os preços eram commodos... Anúncios de jornais brasileiros do século XIX. São Paulo: Humanitas, Série Diachronica vol. 2, 2000.

GUÉRON, Jaqueline. Inalienable possession, PRO-inclusion and lexical chains. In: Grammatical representation. Jaqueline; Guéron, H. G Obenauer, and Jean-Yves Pollock. 1985. (eds). Dordrecht: Foris. 43-86, 1985.

HOLMBERG, A, Is there a little pro. Linguistic Inquiry, 36:533-564, 2005.

HORNSTEIN, N. Movement and control. Linguistic Inquiry, 30: 69-96. 1999.

HOLMBERG, A.; NAYUDU, A. \& SHEEHAN, M. Three partial null subject languages: a comparison of Brazilian Portuguese, Finnish and Marathi. Studia Linguistica, v.63(1), p. 5997. 2009.

HORROCKS, G e M. STAVROU. Bounding Theory and Greek Syntax: Evidence for whmovement in NP. Journal of Linguistics 23:79-108, 1987.

HUANG, C.T.J Prod-drop in Chinese: a generalized control theory. In: O.Jaeggli \& K.J.Safir (orgs),pp. 185-214, 1989.

HYAMS, N. Language Acqusition and the Theory of parameters. Dordrecht: D.Reidel, 
1986.

HYAMS, N. The null subject parameter in language acqusition . In: Jaeggli \& Safir (eds) The Null Subject Parameter. Amsterdam: Kluwer, 1989.

KATO, M. A complementariedade dos possessivos e das construções genitivas no português coloquial. DELTA 1:1/2. 107-120, 1985.

KATO, Mary Aizawa. Português Brasileiro falado: aquisição em contexto de mudança lingüística, In: I.Duarte e I.Leiria (eds.) Actas do Congresso Internacional sobre o Português. Vol II: p.211-237, 1996.

KATO, Mary Aizawa A gramática do letrado: questões para a teoria gramatical. In: MARQUES,M.A;. KOLLER, E.; TEIXEIRA, J. e LEMOS, A. S. (orgs.) Ciências da Linguagem: trinta anos de investigação e ensino. Braga: CEHUM (U. do Minho). p. 131$145,2005$.

KATO, Mary Aizawa; TARALLO, Fernando. Anything you can do in Brazilian Portuguese. In: JAEGGLI, Osvaldo ; SILVA-CORVALÁN, Carmen. (eds). Studies in Romance Linguistics. Dordrecht: Foris, 1986.

KATO, Mary Aizawa; TARALLO, Fernando. The Loss of VS Syntax in Brazilian Portuguese. In SCHLIEBEN-LANGEN, Brigitte; KOCH, Ingedore.V.; JUNGBLUTH, Konstanze.(hrsg) Dialog zwischen den Schulen. Münster: Nodus Publikationen, 2003.

KATO, M.A.; CYRINO, S.; CORREA, E.V.R. Brazilian Portuguese and the recovery of lost clitics through schooling. In: PIRES, A.; ROTHMAN, J. (eds.) Minimalist Inquiries into Child and Adult Language Acquisition: Case Studies across Portuguese. Mouton, 2009.

KAYNE, R. The Antisymmetry of Syntax. Cambridge, Mass.: MIT Press, 1994.

KROCH, A. Reflexes of Grammar in Patterns of Language Change. In: Sankoff, D.; Labov, W. \& Kroch, A. (eds.). Language Variation and Change. vol.1. n.3. 199-244. Cambridge University Press. New York, 1989.

KROCH, A. Morphosyntactic variation. In: Beals, K. et al. (orgs.). Parasession on variation and linguistic theory. Papers from the $30^{\text {th }}$ regional meeting of the Chicago Linguistic Society, 1994.

KROCH, A. Syntactic Change. In: Baltin, M. \& Collins, C. (eds.). The Handbook of Contemporary Syntactic Theory. Oxford. Blackwell. 629-7399, 2000.

LABOV, William. Sociolinguistic patterns. Philadelphia: University of Pennsylvania Press, 1972.

LABOV, William. Building on empirical foundations. In: LEHMANN, W., MALKIEL, Y. (eds.) Perspectives on historical linguistics. Amsterdan/Philadelphia: John Benjamins, 1982.

LABOV, William. Princípios del cambio lingüístico. vol. 1. Trad. de Pedro Martin Butragueño. Madrid: Gredos, 1994.

LABOV, William. Principles of Linguistic Change. Vols. 1 e 2. Malden/Mass.Blackwell, 
2001.

LIGHTFOOT, D. The development of language: acquisition, change and evolution. Oxford. Blackwell, 1999.

LONGOBARDI, G. Reference and proper names: a theory of N-movement in syntax and Logical Form. Linguistic Inquiry. 25 (4). 609-665, 1994.

LYONS, C. 'On the origin of the Old French strong-weak possessive distinction. Transactions of the Philological Society 1-41, 1986.

LYONS, Christopher. Definiteness. Cambridge. University Press, 1999.

Magalhães, T. O Uso do Artigo Definido de Pronome Possessivo em Textos Portugueses do Século XVI a XIX. Qualificação em Sociolingüística, 2002.

MAGALHÃES, T. O uso do artigo definido diante do pronome possessivo em textos portugueses do século XIV a XIX. In: Leitura Maceió. 47. 123-143, 2004.

MARINS, Juliana Esposito. O parâmetro do sujeito nulo: uma análise contrastiva entre o português e o italiano. Dissertação de Mestrado. Rio de Janeiro: UFRJ, 2009.

MARTINS, Ana Maria. Documentos Portugueses do Noroeste e da Região de Lisboa: Da Produção Primitiva ao Século XVI. Lisboa: Imprensa Nacional-Casa da Moeda, 2001.

MATTOS E SILVA, R. V. Estruturas Trecentistas. Elementos para uma gramática do Português Arcaico. Lisboa: Imprensa Nacional-Casa da Moeda, 1989.

MENUZZI, S. 3rd Person Possessives in Brazilian Portuguese: On the Syntax-Discourse Relation In: Botley, S. (ed.) Proceedings of the Discourse Anaphora and Anaphora Resolution Colloquium, Working Papers collection. Dept. of Linguistics of Lancaster University. UK, 1999.

MIGUEL, M. Para uma tipologia dos possessivos. In: Actas do XVII Encontro Nacional da Associação Portuguesa de Linguística. Lisboa. APL. 287-299, 2002.

MIGUEL, M. O Sintagma Nominal em Português Europeu: posições de sujeito. Tese de doutorado. Faculdade de Letras da Universidade de Lisboa, 2004.

MODESTO, Marcelo. On the identification of null arguments. PhD Thesis. USC, 2010.

MONTEIRO, J. Pronomes Pessoais. Subsídios para uma Gramática do Português do Brasil. Fortaleza. CE: Editora da Universidade Federal do Ceará, 1994.

MONTEIRO, J.L. Para compreender Labov. 2. ed. Petrópolis: Vozes, 2000.

MÜLLER, A. The semantics of generic quantification in Brazilian Portuguese. Probus.14: 279-298, 2002.

MUNN, A. \& SCHMITT, C. Number and indefinites. Língua. 115:821-855, 2005.

NAMIUTI, C. Aspectos da história gramatical do português: Interpolação, negação e mudança. Tese de doutorado. Campinas, IEL-UNICAMP, 2008. 
NEGRÃO, E. \& MÜLLER, As Mudanças no Sistema Pronominal Brasileiro; Substituição ou Especialização de Formas. DELTA. 12. 125-152, 1996.

NEVES, M. H. M. 'Possessivos', In: Castilho, A. T. (1993) (org) Gramática do Português Falado, Vol. III: As Abordagens, FAPESP, Editora da Unicamp, Campinas, p. 149-211. 1993.

NUNES, Jairo M. O famigerado SE: uma análise sincrônica e diacrônica das construções com se apassivador e indeterminador. Dissertação de Mestrado. UNICAMP, 1990.

OUHALLA, J. The Syntax of head Movement: a study of Berber. Ph.D. Diss. UCL, 1988.

PALLADINO NETTO, L. Uma edição de cartas de mercadores portugueses do século XVIII e o uso variável do artigo diante do possessivo. Tese de Doutorado. Rio de Janeiro: Faculdade de Letras/ UFRJ, 2009.

PAIXÃO DE SOUSA, M. C. Língua Barroca: Sintaxe e História do português nos 1600. Tese de Doutorado. Campinas, IEL, UNICAMP, 2004.

PEREIRA, D. C. Variação e mudança no uso dos pronomes reflexivos no português popular da capital paulista: Uma abordagem funcionalista e cognitivista. Tese de doutorado. São Paulo: USP, 2007.

PERINI, M. A. A gramática gerativa: introdução ao estudo da sintaxe portuguesa. $2^{\mathrm{a}}$ ed. Belo Horizonte: Virgília, 1985.

RINKE, E. A combinação de artigo definido e pronome possessivo na história do português. Estudos lingüística galega. 2 121-139, 2010.

RIBEIRO, I. \& TORRES MORAIS, M. A. Gramáticas dos possessivos seu/dele: do português arcaico para o português brasileiro. In: Andrade, M. L. \& Rauber, A. L. (org.). Anais de resumos do segundo congresso internacional de linguística histórica. São Paulo, Ed. Humanitas 366-375, 2012.

RITTER, E. Two Functional Categories in Noun Phrases: Evidence from Modern Hebrew. In. S. Rothstein (ed.) Syntax and Semantics 26, Academic Press, San Diego 37-62,1991.

RIZZI, L. Issues in Italian Syntax. Dordrecht: Foris, ROBERTS, Ian (2007) Diachronic Syntax. Oxford: Oxford University Press, 1982.

ROBERTS, Ian; KATO, Mary Aizawa (orgs.) Português Brasileiro: uma Viagem Diacrônica: Homenagem a Fernando Tarallo. Campinas. SP: Editora da Unicamp. 1993.

ROBERTS, Ian; ROUSSEAU, Anna Syntactic change: a Minimalist Approach to Grammaticalization. Cambridge. Cambridge University Press, 2003.

RODRIGUES, C. Impoverished Morphology and A-Movement out of Case Domains. PhD Dissertation. University of Maryland, 2004.

RODRIGUES, C. Possessor raising through thematic positions. In: Hornstein, N. \& Polinsky, M. (eds.). Movement Theory and Control. 119-146, 2010.

SCHERRE, Maria Marta Pereira. Reanálise da concordância nominal em português. $\mathrm{PhD}$ 
Dissertation, Universidade Federal do Rio de Janeiro, 1988.

SCHERRE, M. M. P. Aspectos da concordância de número no português do Brasil. Revista Internacional de Língua Portuguesa (RILP) - Norma e Variação do Português. Associação das Universidades de Língua Portuguesa. 12:37-49, 1994.

SCHERRE, Maria Marta Pereira and Anthony Julius Naro. Restrições sintáticas e semânticas no controle da concordância verbal em português. Fórum Linguístico 1(1): 45-71, 1998.

SCHOORLEMMER, M. Possessors, Articles and Definiteness In: Alexiadou, A. \& Wilder, C. (eds). Possessors, Predicates and Movement in the Determiner Phrase. John Benjamins Publishing Company. 56-86, 1998.

SILVA, G. M. de O. Estudo da Regularidade na Variação dos Possessivos no Português do Rio de Janeiro. Tese de Doutorado. Rio de Janeiro, UFRJ, 1982.

SILVA, G. M. de O. e CALlOU, D. 'O uso do artigo definido diante de possessivo'. In: Duarte, I. \& Leiria, I. (orgs.) Congresso Internacional sobre o Português, Colibri/APL, Lisboa, Vol. III. p. 115-125, 1996.

STOWELL, T. The Role of the Lexicon in Syntax Theory. In Stowel and Wehrli (eds), Syntax and Semantics, vol. 26. Syntax and the Lexicon, 9-18, 1992.

SZABOLSCI, A. The Possessors that run away from home. The Linguistic Review 3:98-102, 1983.

SZABOLSCI, A. Functional Categories in the Noun Phrase. In. Kenesei (ed.) Approaches to Hungarian 2, 167-190-JTE. Szeged, 1987.

VERGNAUD, J-R \& ZUBIZARRETA, M. L. The definite determiner and the in alienable constructions in French and in English. Linguistic Inquiry. 23:595-652, 1992.

von HEUSINGER, Klaus.. Definiteness. In: Oxford bibliographies online: Linguistics .

New York: Oxford University Press. 2011

von PETEGHEM, Marleem. Folia Linguistica 46/2. Mouton de Gruyter - Societas Linguistica Europaea, 2012.

TARALLO, Fernando; KATO, Mary Aizawa Harmonia trans-sistêmica: variação intra e inter-lingüística. Preedição 5. Campinas, 1989. (Reeditado in Diadorim: revista de estudos lingüísticos e literários 2. Publicação do Programa de Pós-Graduação em Letras Vernáculdas da UFRJ, 2007.

TARALDSEN, K. D-projections and N-projection in Norwegian. In: J. Mascarò e Marina Nespor (eds) Grammar in Progress. Dordrecht: Foris, 419-431, 1990.

TORRES MORAIS, M. A. Dativos de Posse no Português Brasileiro: um estudo comparativo com o Português Europeu. Trabalho de Pós Doutorado. University of Southern, California, 2014.

TORRES MORAIS, M. A.; BERLINCK, R. A. Em busca do português paulista. In: História do português paulista / TORRES MORAIS, M. A; ANDRADE, M. L. C. V. O. (orgs.). Campinas, UNICAMP: 2009. 
WEINREICH, U., LABOV, W. HERZOG. M. Empirical foundations for a theory of language change. In: LEHMANN, W. \& MALKIEL, Y. (eds.) Directions for historical linguistics. Austin: University of Texas Press, 1968.

ZAMPARELLI, Roberto. Layers in Determiner Phrase. PhD dissertation, University of Rochester, 1995. Published by Garland. New York, 2000.

ZEIJLSTRA, Hedde. There is only one way to agree. The Linguistic Review 29(3): 491-539, 2012.

ZRIBI-HERTZ, Anne. On the asymmetrical but regular properties of French possessive DPs. In: Martine Coene and Yves D'Hulst (eds.). From NP to DP Volume II: The Expression of Possession in Noun Phrases. Amsterdam: John Benjamins.141-166, 2003. 